\title{
TEKNOLOGI MATERIAL MAJU Prinsip Dasar dan Aspek Rekayasa
}

\author{
Dr. Rahadian Zainul, S.Pd., M.Si
}




\section{UNDANG-UNDANG REPUBLIK INDONESIA \\ NO 19 TAHUN 2002}

\section{TENTANG HAK CIPTA}

\section{PASAL 72}

\section{KETENTUAN PIDANA}

\section{SAKSI PELANGGARAN}

1. Barangsiapa dengan sengaja dan tanpa hak mengumumkan atau memperbanyak suatu Ciptaan atau memberi izin untuk itu, dipidana dengan pidana penjara paling singkat 1 ( satu) bulan dan/atau denda paling sedikit Rp 1.000.000,00 (satu juta rupiah), atau pidana penjara paling lama 7 (tujuh) tahun dan/atau denda paling banyak Rp. 5.000.000.000,00 (lima milyar rupiah)

2. Barangsiapa dengan sengaja menyerahkan, menyiarkan, memamerkan, mengedarkan, atau menjual kepada umum suatu Ciptaan atau barang hasil pelanggaran Hak Cipta atau Hak Terkait sebagaimana dimaksud dalam ayat (1), dipidana dengan pidana penjara paling lama 5 (lima) tahun dan/atau denda paling banyak Rp 500.000.000,00 (lima ratus juta rupiah). 


\section{TEKNOLOGI MATERIAL MAJU Prinsip Dasar dan Aspek Rekayasa}

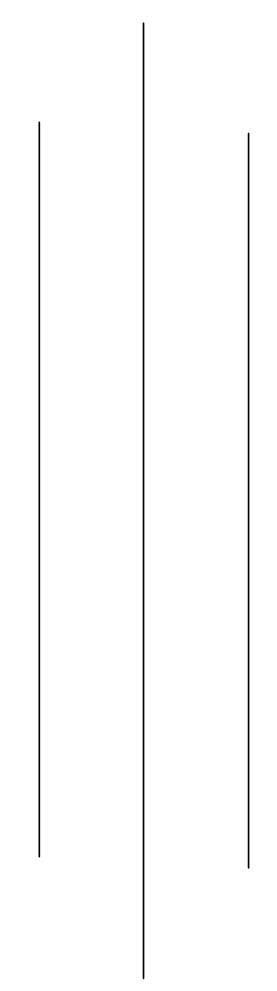

Dr. Rahadian Zainul, S.Pd., M.Si. 


\title{
TEKNOLOGI MATERIAL MAJU
}

\section{Prinsip Dasar dan Aspek Rekayasa}

\author{
Penulis : \\ Dr. Rahadian Zainul, S.Pd., M.Si.
}

\section{Editor :}

Dr. Desy Kurniawati, M.Si. (Editor)

ISBN : 978-602-5994-44-9

\section{BERKAH PRIMA}

Alamat: Jalan Datuk Perpatih Nan Sabatang 287, Air Mati, Solok Sumatera Barat.

\section{Anggota IKAPI Pusat}

No. Anggota : 016/SBA/I8 tanggal I Agustus 2018

Cetakan Pertama,

Hak Cipta dilindungi oleh undang-undang.

Dilarang memperbanyak atau memindahkan sebagian atau seluruh isi buku ini dalam bentuk apapun. Secara elektronis maupun mekanis, termasuk memfotocopy, merekam, atau dengan teknik perekaman lainnya, tanpa izin tertulis dari penerbit

Tajuk entri utama : Rahadian,

\section{TEKNOLOGI MATERIAL MAJU}

Prinsip Dasar dan Aspek Rekayasa

Edisi Pertama, cet. Ke-I Padang: Berkah Prima, 2018

Editor : Tim editor ( Desy Kurniawati )

I (satu) jilid; |4,8x2 I cm (A5), Isi I 70 hal. + (xviii )

ISBN:

Editor isi (Substansi): Dr. Desy Kurniawati, M.Si.

Editor Bahasa: Dr.Nasbahry Couto, M.Sn..

Desainer Grafis : Annisa Awalliyah

Perwajahan: Tim Layout CV. Berkah Prima 


\section{KATA PENGANTAR}

Alhamdulillah, buku berjudul TEKNOLOGI MATERIAL MAJU : Prinsip Dasar dan Aspek Rekayasa, telah berhasil disusun. Semoga buku ini dapat bermanfaat dalam pengembangan ilmu pengetahuan, khususnya dalam bidang Katalis dan Kimia Industri. Semua manuscript yang disusun merupakan hasil riset dan literasi yang dilakukan selama kajian Penelitian tahun pertama 2018 dan kajian kuliah Kimia Material.

Buku TEKNOLOGI MATERIAL MAJU : Prinsip Dasar dan Aspek Rekayasa ini, dapat digunakan oleh Mahasiswa dan Peneliti yang tertarik dalam pengembangan material dan katalis. Dalam buku ini ada dasar pembuatan katalis dan material secara integralistik dikaji berdasarkan bagian dan tekniknya masing masing.

Buku ini berisi dari berbagai sisi pengembangan katalis dan material maju untuk penanganan limbah, sensor, elektroda dan sintesis material lainnya, termasuk material turunan. Pada Buku ini, lebih banyak penekanan pada aspek rekayasa dari review terbaru jurnal dan kajian penelitian di berbagai negara.

Akhirulkalam, terima kasih dan semoga bermanfaat.

Oktober 2018

Dr. Rahadian Zainul, S.Pd., M.Si. 


\section{DAFTAR ISI}

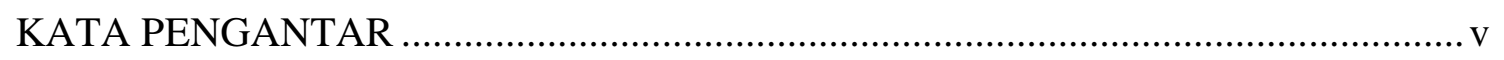

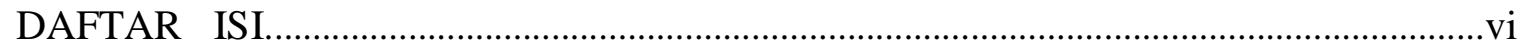

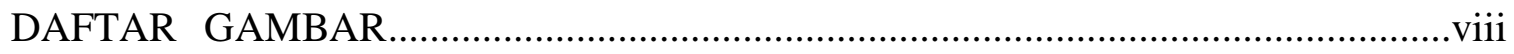

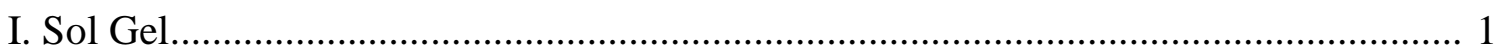

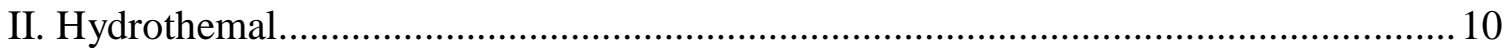

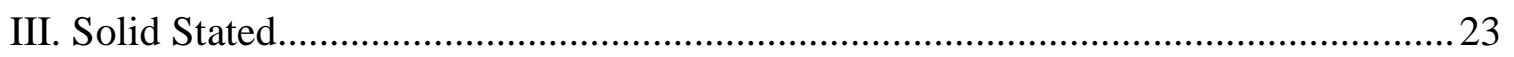

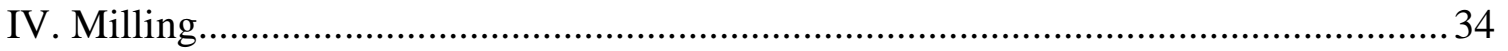

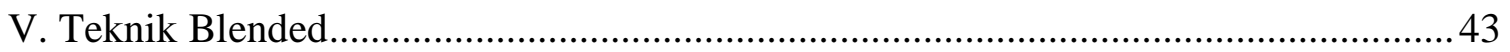

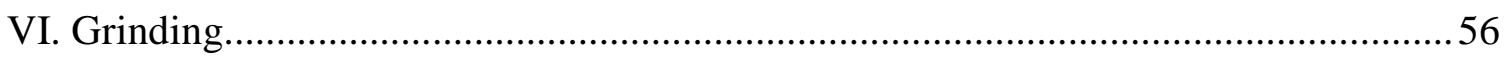

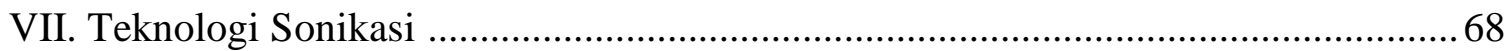

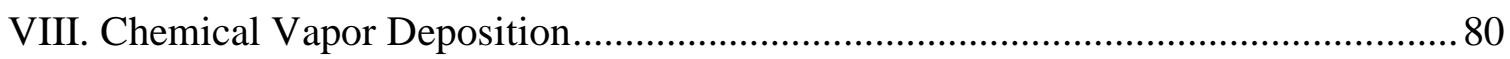

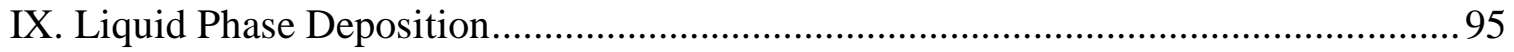




\title{
a review
}

\section{SOL GEL : PRINCIPLE AND TECHNIQUE}

\author{
Yulia Mona Liza ${ }^{* 1}$, Rizka Chairani Yasin², Suci Sri Maidani ${ }^{2}$, Rahadian Zainul ${ }^{2}$ \\ ${ }^{1}$ Pendidikan Kimia,FMIPA, Universitas Negeri Padang, Indonesia \\ ${ }^{2}$ Pendidikan Kimia,FMIPA, Universitas Negeri Padang, Indonesia \\ ${ }^{3}$ Pendidikan Kimia,FMIPA, Universitas Negeri Padang, Indonesia \\ ${ }^{4}$ Physical Chemistry Laboratory, Universitas Negeri Padang, Indonesia \\ *E-mail : yuliamona12@gmail.com,rizkachairaniy@gmail.com \\ sucisrimaidani@gmail.com, rahadianzmsiphd@yahoo.com
}

\begin{abstract}
Abstrak. Metode sol gel merupakan salah satu metoda sintesis nanopartikel yang menerapkan 2 tahapan fasa penting yaitu sol dan gel. Tujuan review ini adalah untuk mengetahui prinsip dan teknik pada proses pembuatan sol gel. Prinsip metoda sintesis dengan teknik sol gel ini adalah pembentukan senyawa awal ( prekursor ) yang terdiri dari garam-garam organik atau senyawa metal organik, terjadinya polimerisasi larutan, terbentuknya, dan membutuhkan proses pengeringan dan kalsinasi untuk menghilangkan senyawa organik serta membentuk material anorganik berupa oksida. Beberapa material yang dihasilkan dengan menggunakan metode sol gel ini adalah ceramic fibers, thin film coating, monolithic ceramics and glasses.
\end{abstract}

Keywords : sol gel, prinsip, teknik.

\section{Pendahuluan}

Dalam pembuatan material(49) terdapat beberapa metode yang dapat digunakan, salah satunya adalah dengan metode sol gel(14; 50-54). Metode sol gel ini banyak digunakan dalam pembuatan keramik(2; 4; 6; 16; 55-66) dan material gelas(67-69). Dengan menggunakan metode sol gel ini akan memungkinkan membentuk ukuran partikel skala nano(70-74) sekaligus membentuk penampakan morfologi yang homogen $(1 ; 75)$. Sol merupakan suatu suspensi koloid dimana fasa terdispersinya berupa zat padat dan pendispersinya berupa zat cair. Sedangkan gel merupakan suatu zat yang memiliki pori semirigid yang terdiri dari jaringan kontinu dalam tiga dimensi yang terbentuk dari rantai polimer(76-78)

\section{Metode}

Pada proses sol gel dapat menghasilkan material dengan kemurnian dan kekuatan yang lebih tinggi dibandingkan dengan metode lain. Proses sol gel berlangsung dalam beberapa tahapan yang dapat dilihat pada fishbone di bawah ini. 


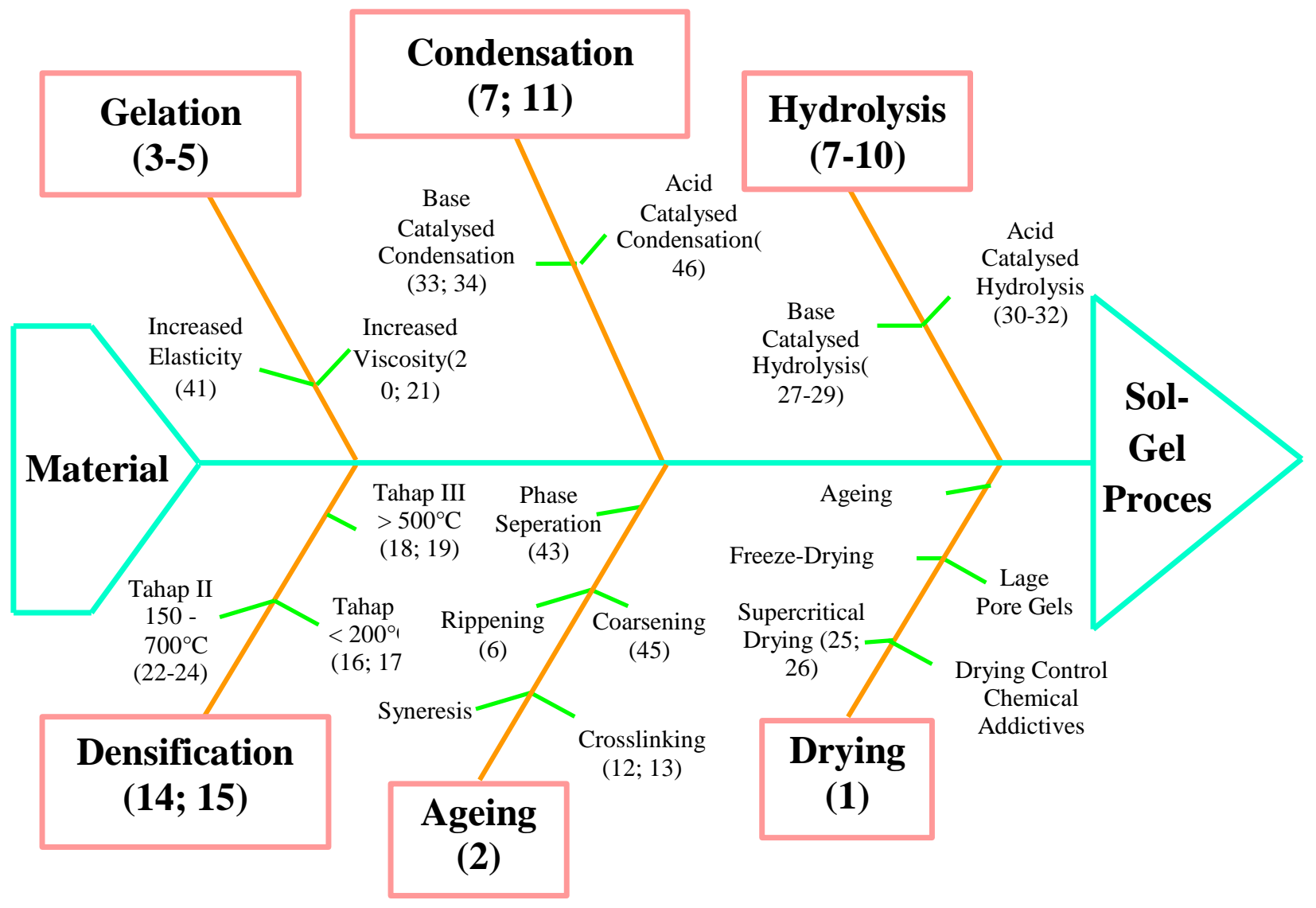

Bagan 1. FishBone sol-gel

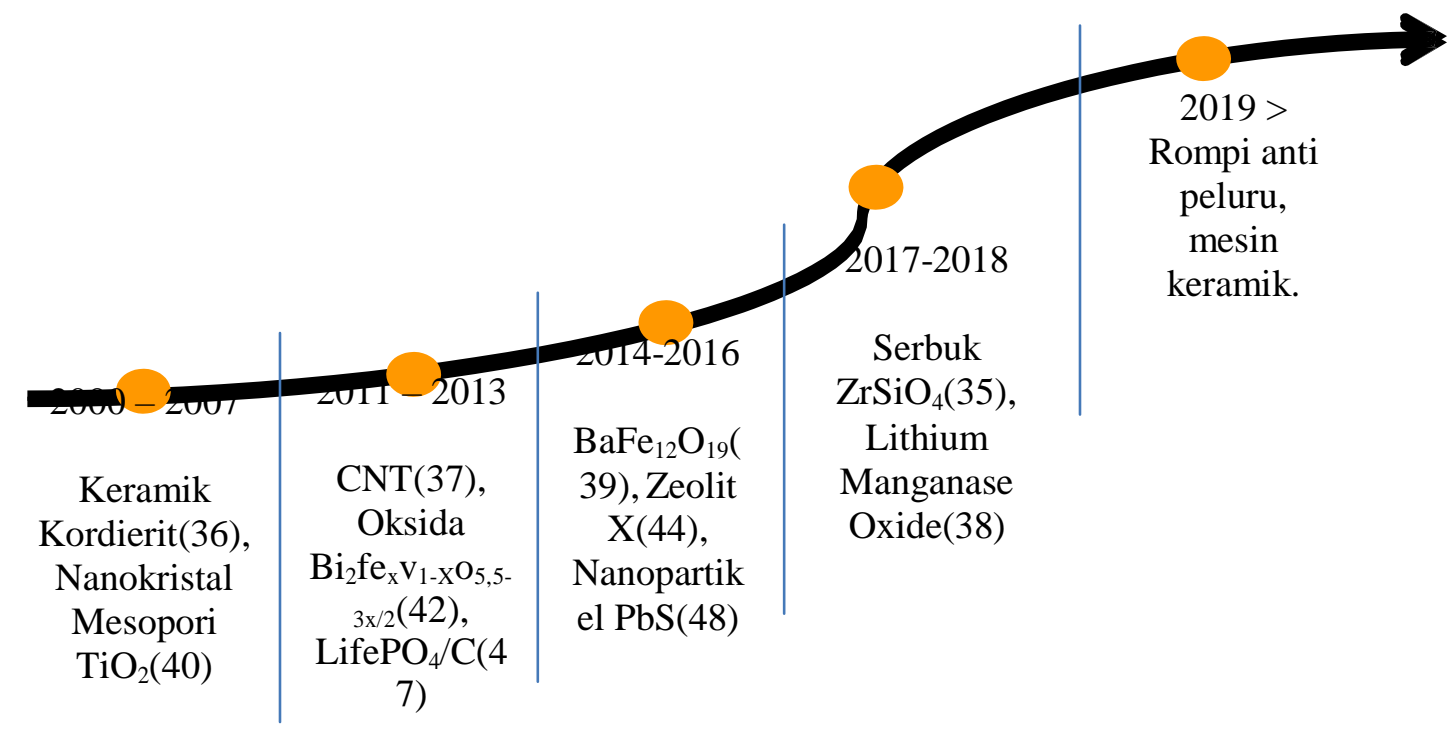

Bagan 2. Road Maps Sol-gel 


\section{Keterangan}

2000 Pembuatan Keramik Kordierit Dengan Metode Sol - Gel Dan Karakterisasinya

2007 Sintesa Nanokristal Mesopori $\mathrm{TiO}_{2}$ Dengan Metoda Sol-Gel

2011 Sintesis Lapisan Tipis Nanokomposit $\mathrm{TiO}_{2} / \mathrm{CNT}$ Menggunakan Metode Sol Gel Dan Aplikasinya Untuk Fotodegradasi Zat Warna Azo Orange 3R

2012 Sintesis Oksida $\mathrm{Bi}_{2} \mathrm{fe}_{\mathrm{x}} \mathrm{v}_{1-\mathrm{X}} \mathrm{O}_{5,5-3 \mathrm{x} / 2}$ Dengan Metode Sol Gel Dan Reaksi Kimia Padat

2013 Pengaruh pH, Suhu Dan Waktu Pada Sintesis LifePO $_{4} / \mathrm{C}$ Dengan Metode Sol-Gel Sebagai Material Katoda Untuk Baterai Sekunder Lithium

2014 Penerapan Metode Sol Gel Dengan Variasi Temperatur Dan Waktu Kalsinasi Pada Sintesis Barium M-Heksaferit $\left(\mathrm{BaFe}_{12} \mathrm{O}_{19}\right)$

2015 Sintesis Karakterisasi Zeolit X Dari Abu Vulkanik Gunung Belud Dengan Variasi Suhu Hidrotermal Menggunakan Metode Sol Gel

2016 Sintesis Nanopartikel PbS Melalui Metode Sol Gel Dengan EDTA Sebagai Capping Agent Synthesis Of PbS

2017 Sintesis Dan Karakterisasi Serbuk $\mathrm{ZrSiO}_{4}$ Dengan Metode Sol Gel

2018 Sol-Gel synthesis of Silicon Doped Lithium Manganase Oxide with Enhanced Reversible Capacity and Cycling Stability 


\section{Hasil dan Pembahasan}

\section{a. Sejarah penggunaan metode sol gel}

Sol-gel merupakan suatu istilah yang umum digunakan untuk menggambarkan preparasi material keramik melalui beberapa tahapan yang meliputi pembuatan sol, gelasi sol, dan penghilangan fasa cair. Sol merupakan suatu suspensi koloid dimana fasa terdispersinya berupa zat padat yang masih mengalami Brownian motion ( gerak Brownian) atau diffusion Brownian (difusi Brownian ) dan pendispersinya berupa zat cair. Sedangkan gel merupakan suatu zat yang memiliki pori semirigid yang terdiri dari jaringan kontinu dalam tiga dimensi yang terbentuk dari rantai polimer. Metode sol-gel merupakan metode yang digunakan untuk membuat suatu material padat dari nonopartikel atau molekul yang berukuran kecil terutama digunakan untuk fabrikasi dari oksida logam seperti silikon(Si)(79) dan titanium(Ti)(80).

Pada tahun 1950, metode sol-gel dikembangkan untuk membuat bubuk radioaktif dari $\mathrm{UO}_{2}$ dan $\mathrm{ThO}_{2}$ untuk bahan bakar nuklir. Dengan menggunakan metode sol-gel ini akan menghasilkan baham bakar tanpa generasi debu dalam jumlah besar.

Pada tahun 2000 metode sol gel digunakan pada pembuatan keramik kordierit(36). Penggunaan metode polimerisasi sol gel, khususnya pembuatan elektrokeramik multi komponen sangat menguntungkan dari segi material yang dihasilkan. Keuntungan penggunaan metode sol gel dalam pembuatan keramik ini akan menghasilkan homogenitas dan kemurnian yang tinggi, prosesnya juga berlangsung pada suhu rendah. Faktor yang mempengaruhi proses sol menjadi gel adalah $\mathrm{pH}$, perbandingan air, alkoksida, jenis pelarut dan konsentrasi, serta suhu dari alkoksida.

Pada tahun 2007, metoda sol-gel digunakan untuk mensintesa Nanokristal Mesopori(40) $\mathrm{TiO}_{2}$. Sintesis $\mathrm{TiO}_{2}$ menggunakan alkohol sebagai pelarut dan juga block polymer. $\mathrm{TiCl}_{4}$ digunakan sebagai prekursor yang lebih mudah didapatkan dibandingkan titanium alkoksida. Larutan akan bersifat asam karena adanya $\mathrm{HCl}(81)$ akibat reaksi $\mathrm{TiCl}_{4}$ dengan alkohol. Karakteristik self assembly dari block copolymer akan menghasilkan nanokristal $\mathrm{TiO}_{2}(82)$ dengan struktur mesopori.

Pada tahun 2011, metode sol-gel digunakan untuk sintesis nanokomposit $\mathrm{TiO}_{2} / \mathrm{CNT}(37)$ sebagai material fotokatalis yang disintesis menggunakan metode sol gel melalui pendispersian $\mathrm{TiO}_{2}$ merck komersial pada CNT. Struktur kristal dan morfologi lapisan tipis nanokomposit $\mathrm{TiO}_{2} / \mathrm{CNT}$ dikarakterisasi menggunakan XRD dan SEM.

Tahun 2012, metoda sol-gel digunakan untuk sintesa oksida $\mathrm{Bi}_{2} \mathrm{Fe}_{\mathrm{x}} \mathrm{V}_{1-\mathrm{x}} \mathrm{O}_{5,5-3 \mathrm{x} / 2}$ (42). Oksida BIFEVOX disintesis menggunakan metode SSR maupun dengan metode SG merupakan oksida berwarna coklat. Pola XRD oksida yang disintesis menggunakan metode SSR menunjukkan bahwa intensitas puncak cenderung turun dengan kenaikan konsentrasi ion besi. Pada metode SG pola XRD-nya masih menunjukkan adanya ketidakmurnian pada oksida BIFEVOX, yaitu masih adanya fasa $\mathrm{BiVO}_{4}$ dan $\mathrm{Bi}_{8} \mathrm{~V}_{2} \mathrm{O}_{17}$ sebagai fasa sekunder. Perbedaan oksida BIFEVOX yang disintesis menggunakan metode SSR dan SG adalah kehomogenan oksida yan dihasilkan.

Pada tahun 2013, metode sol-gel digunakan untuk sintesis $\mathrm{LiFePO}_{4} / \mathrm{C}$ (47) sebagai material katoda baterai sekunder litium. Bahan pembentuk $\mathrm{LiFePO}_{4}$ adalah serbuk $\mathrm{Li}_{2} \mathrm{CO}_{3}$, $\mathrm{FeC}_{2} \mathrm{O}_{4} \cdot 2 \mathrm{H}_{2} \mathrm{O}$ dan $\mathrm{NH}_{4} \mathrm{H}_{2} \mathrm{PO}_{4}$. Asam sitrat digunakan sebagai sumber karbon pada material katoda $\mathrm{LiFePO}_{4}$. Parameter yang diukur pada sintesis $\mathrm{LiFePO}_{4} / \mathrm{C}$ adalah nilai keasaman $(\mathrm{pH})$, suhu dan waktu sinter. Metode sintesis sol-gel menawarkan keuntungan menghasilkan ukuran partikel yang optimum dan menjaga kemurnian fasa. Pada sintesis $\mathrm{LiFePO}_{4} / \mathrm{C}$ ini menggunakan pelarut berupa akuades sehingga menghasilkan partikel dengan morfologi yang baik dan homogen.

Selanjutnya tahun 2014, penggunaan metode sol-gel berkembang pada sintesis Barium M-heksaferit $\left(\mathrm{BaFe}_{12} \mathrm{O}_{19}\right)$ (39). Tahap awal pembuatan $\left(\mathrm{BaFe}_{12} \mathrm{O}_{19}\right)$ adalah membuat $\mathrm{Fe}_{2} \mathrm{O}_{3} \mathrm{H}_{2} \mathrm{O}$ yang dilarutkan dalam $\mathrm{HNO}_{3} 14,7 \mathrm{M}$ dan diaduk selama 45 menit pada suhu $70^{\circ} \mathrm{C}$ sehingga diperoleh larutan ferit nitrat yang berwarna merah bening. Pada waktu yang sama serbuk 
$\mathrm{BaCO}_{3}(83)$ dilarutkan dalam $\mathrm{HNO}_{3} 8 \mathrm{M}$, ditambah $\mathrm{H}_{2} \mathrm{O}$ dan diaduk selama 90 menit, sehingga diperoleh larutan barium nitrat yang berwarna bening. Kedua larutan dicampurkan pada suhu tertentu sehingga diperoleh sol Ba-Fe. Untuk menghasilkan gel makan sol. Ba-Fe dikeringkan

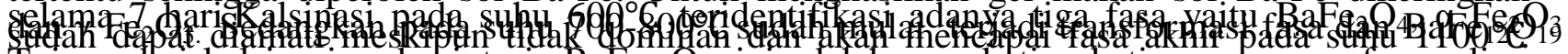
Tujuan dari kalsinasi pada sintesis $\mathrm{BaFe}_{12} \mathrm{O}_{19}$ in1 adalah agar kation-kation penyusun fasa saling berikatan satu sama lain membentuk kristal. Pembentukan Barium M-Heksaferit dipengaruhi oleh suhu dan waktu kalsinasi. Metode sol-gel terbukti mampu menghasilkan sebuk Barium MHeksaferit.

Pada tahun 2015, berkembang sinstesis Zeolit X(44) pada metode sol gel. Zeolit adalah suatu material anorganik yang berpori berupa kristalin dengan struktur tetrahedral pada kerangka tiga dmensi dari $\mathrm{SiO}_{4}$ dan $\mathrm{AlO}_{4}$ yang dihubungkan satu sama lain dengan berbagi atom oksigen untuk membentuk intrakristalin. Sedangkan Zeolit X merupakan salah satu tipe zeolit. Zeolit X memiliki diameter $\alpha$-cage (supercage) $13 \AA$ dan diameter kerangka sodalit 6,6 $\AA$ dengan diameter pori $7,4 \AA$ membentuk struktur tiga dimensi dan rasio $2<\mathrm{SiO}_{2} / \mathrm{Al}_{2} \mathrm{O}_{3}<3$. Zeolit $\mathrm{X}$ yang disintesis melalui metode sol gel menggunakan bahan sintesis yaitu dari water glass sebagai sumber silica (84-87)dengan komposisi molar 4,5 Na $2 \mathrm{O}(88) ; \mathrm{Al}_{2} \mathrm{O}_{3} ; 3 \mathrm{SiO}_{2} ; 315 \mathrm{H}_{2} \mathrm{O}(81)$ dan dari bahan alam sebagai sumber silica, dengan derajat kristalinitas dan kemurnian yang tinggi serta sintesis dilakukan satu tahap. Dalam sintesis zeolit X, terlebih dahulu dilakukan preparasi dan pencucian dengan menggunakan $\mathrm{HCl} 1 \mathrm{M}$. Penggunaan $\mathrm{HCl}$ berfungsi untuk menghilangkan logam oksida dan non logam(89).

Seiring perkembangan zaman pada tahun 2016, metode sol-gel digunakan untuk sintesis nanopartikel $\mathrm{PbS}(48 ; 90)$. PbS ini dipreparasi dengan bahan yaitu SDS (0,05 mmol, 99,0\%) dan EDTA (0,2 mmol, 99,0\%) yang dilarutkan ke dalam $100 \mathrm{ml}$ aquadenim yang telah dipanaskan dengan magnetic stirrer selama 3-5 menit dan diukur $\mathrm{pH}$ larutan tersebut. Kemudian tambahkan $\mathrm{NH} 4 \mathrm{OH}, \mathrm{Pb}(\mathrm{CH} 3 \mathrm{COOH})$ serta $20 \mathrm{ml} \mathrm{NH} 4 \mathrm{~S}$ lalu distirrer, setelah homogen larutan didiamkan hingga mencapai suhu kamar dan disaring. Selanjutnya di oven selama 2-3 jam pada suhu $120^{\circ} \mathrm{C}$ dan dilakukan variasi konsentrasi EDTA. Dengan EDTA sebagai capping agent yang memiliki struktur yang baik dan menunjukkan kecenderungan meningkatkan ukuran partikel dan memperkecil energi celah pita $\mathrm{PbS}$.

Pada tahun 2017, metode sol-gel digunakan untuk mensintesis serbuk $\mathrm{ZrSiO} 4(35 ; 91)$. Zirkon(52; 57; 92-96) merupakan material dalam industri keramik, yang diaplikasikan pada industri keamanan nuklir, mikroelektronik, proteksi lapisan dan bahan pengecoran logam. Zirkon memiliki gabungan senyawa zirkonia $(\mathrm{ZrO} 2)$ dan silica $(\mathrm{SiO} 2)$. Zirkon dapat dengan mudah dipisahkan dengan mineral berat karena nonkonduktor dan nonmagnetik. Pada sintesis zirkon, fase gel dihasilkan dari hidrolisis dan kondensasi dari reaksi metal prekursor alkoksida, dan kemudian dirubah menjadi xerogel dengan cara pengeringan. Untuk mendapatkan kehomogenan molekul, pada prekursor dilakukan pengadukan menggunakan magnetic stirrer di atas hotplate strirrer ceramic. Pada suhu $100^{\circ} \mathrm{C}$, gel yang tersuspensi membentuk gel yang homogen, dan dilakukan pencucian sebanyak 15 kali pada $\mathrm{pH} 7$ dengan tujuan membuang mineral pengotor. Gel yang telah mengendap akan dikeringkan sehingga menghasilkan serbuk $\mathrm{ZrSiO}_{4}$ dan dilakukan pengujian XRF.

Pada tahun 2018 metode sol-gel berkembang pada sintesis Lithium Mangan Oksida Spinel $\left(\mathrm{LiMn}_{2} \mathrm{O}_{4}\right)(38)$. Dengan serangkaian silicon(97-99) melalui proses sol gel, hasil XRD menunjukkan bahwa sampel silicon yang didoping dapat mempertahankan struktur spinel dari $\mathrm{LiMn}_{2} \mathrm{O}_{4} \cdot \mathrm{LiMn} 2 \mathrm{O} 4$. Doping $(100 ; 101)$ silicon ini menggunakan silicon dengan tetraethoxysilan sebagai dopantnya. Tahap awalnya yaitu lithium hidroksida stoikiometrik dan asam sitrat dilarutkan dalam air. Kemudian tambahkan larutan mangan asetat dan lauratan campuran TEOS, 
larutan etanol $(66 ; 76 ; 102)$ ke dalam larutan yang tadi pada suhu $50^{\circ} \mathrm{C}$ Untuk menyelidiki pengaruh konten doping $\mathrm{Si}$ pada kristal dari $\mathrm{LiMn}_{2} \mathrm{O}_{4}$ dapat dilakukan pengujian XRD(103; 104).

Dengan kemajuan teknologi yang semakin pesat setiap tahunnya, memungkinkan metode sol-gel ini digunakan pada pembuatan rompi anti peluru tembakan senapan dengan kaliber yang besar. Hal ini dikarenakan melalui metode sol ini mampu menghasil partikel dengan ukuran nano. Selain itu metode sol-gel ini juga dapat diterapkan untuk membuat mesin keramik pada mobil.

Metode sol gel terus berkembang dan yang dihasilkan sangat banyak mulai dari serbuk hingga padatan yang keras, secara umum metode sintesis nanopartikel ini melibatkan larutan sebagai medianya mengalami perubahan fasa menjadi sol (koloid yang mempunyai padatan tersuspensi dalam larutannya) dan gel (koloid tetapi mempunyai fraksi soloid yang lebih besar daripada sol)(105-111).

\section{b. Tahapan proses sol gel}

Pada umumnya, tahapan proses sol gel terbagi atas tiga bagian, yaitu hidrolisis, kondensasi alkohol, dan kondensasi air. Ada juga beberapa sumber yang mengatakan bahwasanya tahapan proses sol gel itu terbagi atas empat tahap, yaitu hidrolisis, kondensasi, aging atau pematangan, dan drying atau pengeringan(179-190).

\section{Hidrolisis}

Pada tahap hidolisis terjadi reaksi penggantian gugus alkoksida $(107 ; 112 ; 113)$-OR oleh gugus karboksil - $\mathrm{OH}$. Hidrolisis ini dapat terjadi dalam kondisi asam dan basa. Pada kondisi asam, gugus alkoksida akan terprotonasi dengan cepat. Misalnya, dengan menggunakan Tetraethyl orthosillicate(114) atau biasa disingkat dengan TEOS(115) yang merupakan alkoksida dari silikon, menyebabkan alkoksidanya akan lebih mudah diserang oleh $\mathrm{H}_{2} \mathrm{O}$. Hal ini dikarenakan TEOS tersebut akan mengambil kerapatan dari atom silikon yang mengakibatkan alkoksidanya bersifat elektrofilik. Proses tahapan sol gel dalam kondisi asam ini berjalan sesuai mekanisme $\mathrm{SN}-2$ yang menghasilkan formasi penta-coordinate transition state. Mekanisme hidrolisis pada kondisi asam dapat dilihat pada reaksi di bawah ini :

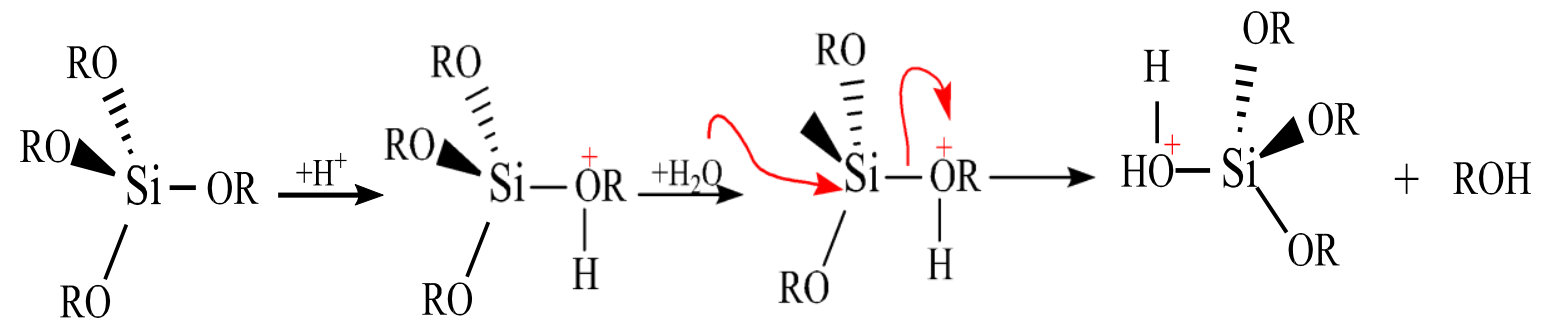

Gambar 1. Mekanisme hidrolisis pada kondisi asam(8)

Dengan konsentrasi katalis yang sama, ternyata alkoksida silikon pada kondisi basa akan terprotonasi lebih lama dibandingkan dengan alkoksida silikon pada kondisi asam yang disebabkan oleh kecenderung oksigen alkoksida untuk menolak gugus $-\mathrm{OH}$. Mekanisme hidrolisis pada kondisi basa dapat dilihat pada reaksi di bawah ini : 


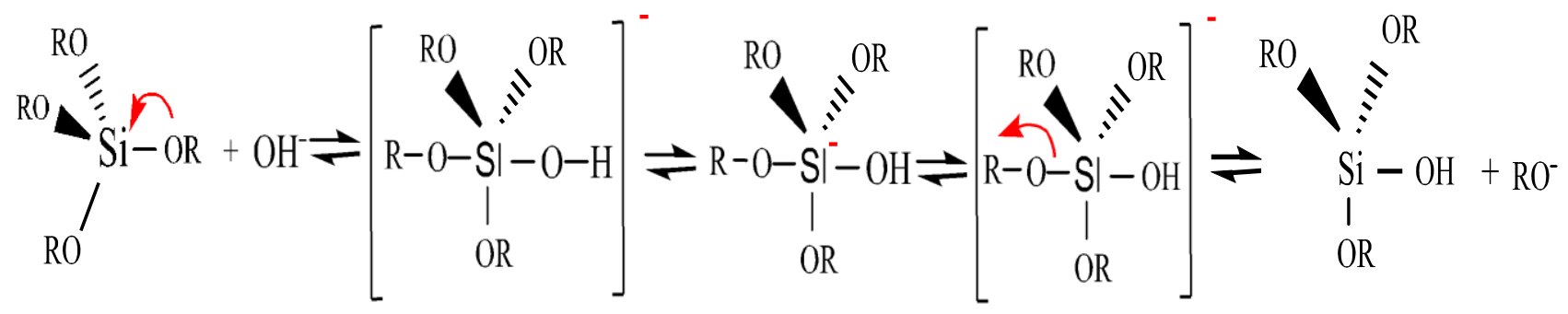

Gambar 2. Mekanisme hidrolisis pada kondisi basa(8)

\section{Kondensasi}

Umumnya reakasi kondensasi ini akan terjadi sebelum reaksi hidrolisis selesai. Molekul yang sudah terhidrolisis akan akan membentuk ikatan siloksan ( $\mathrm{Si}-\mathrm{O}-\mathrm{Si}$ ), dua logam yang digabungkan melalui rantai oksigen(72; 91; 116). Reaksi kondensasi ini terbagi menjadi dua bagian, yaitu kondensasi dalam suasana asam dan kondensasi dalam kondisi basa.

Pada kondisi asam silanol akan terprotonasi yang menyebabkan silikon lebih elektrofilik sehingga lebih mudah diserang oleh nukleofilik. Pada kondisi basa nukleofilik akan menyerang silanol yang terdeprotonasi pada asam silika netral menghasilkan ikatan siloksan. Mekanisme kondensasi dalam suasana asam dan basa dapat dilihat pada reaksi di bawah ini :

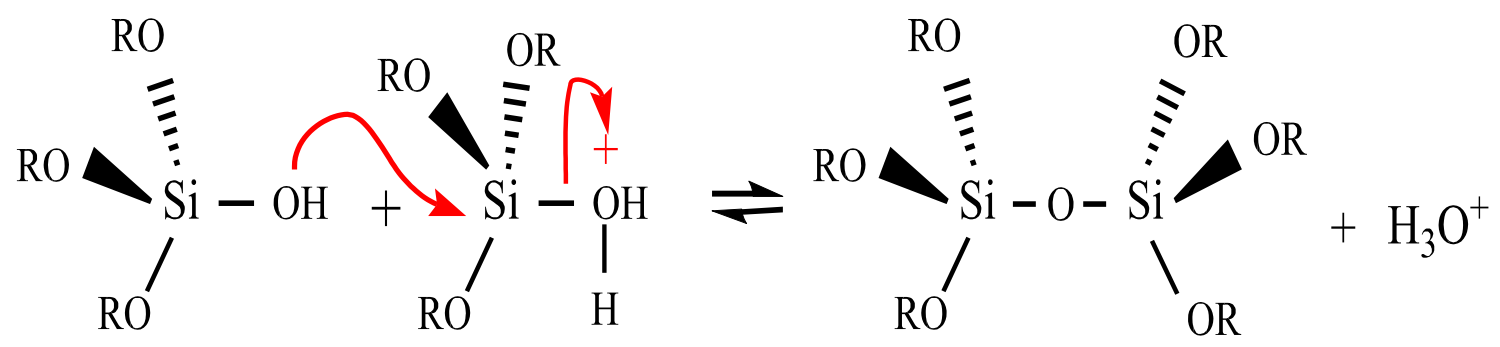

Gambar 3. Mekanisme kondensasi dalam suasana asam(46)

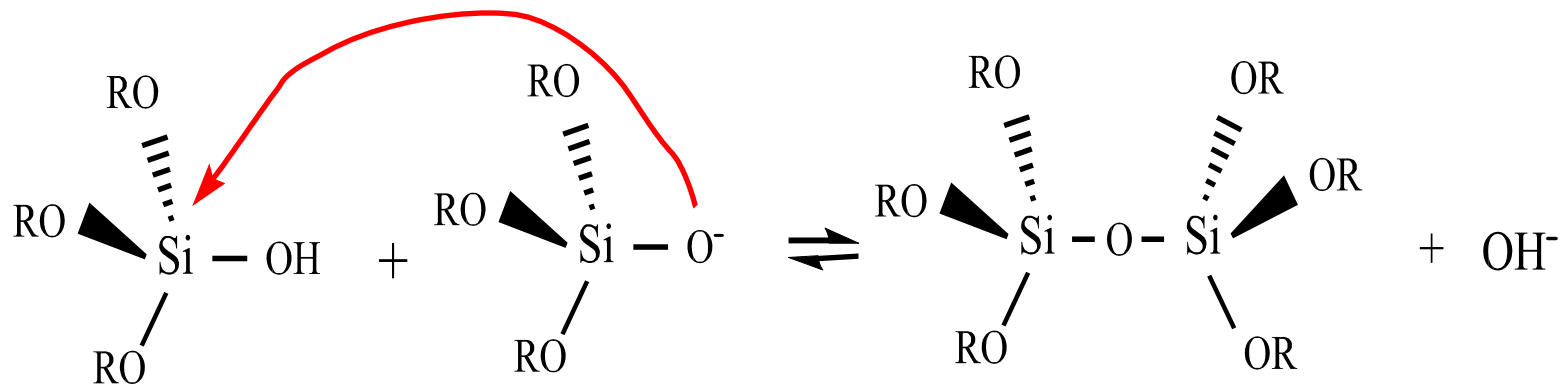

Gambar 4. Mekanisme kondensasi dalam suasana basa(46) 


\section{Aging (pematangan)}

Pada proses pematangan ini, terjadi reaksi pembentukan jaringan gel yang lebih kaku, kuat, dan menyusut di dalam larutan. Fase cair yang masih mengandung partikel padat dan menggumpal akan terus bereaksi dan akan mengembun saat gel mengering. Gel yang dihasilkan sangat fleksibel. Gel tersebut akan semakin kental yang disebabkan oleh kelompok-kelompok cabang disampingnya yang mengembun. Hal ini menyebabkan cairan yang terdapat di dalam gel akan diserap oleh kolompok-kelompok cabang tersebut sehingga gel mengalami penyusutan. Proses ini akan terus berlanjut selama di dalam gel masih terdapat fleksibilitas(2).

\section{Drying ( pengeringan )}

Fase cair atau pelarut yang tersisa perlu dihilangkan atau dibuang melalui proses drying $(1 ; 2 ; 25 ; 26 ; 94 ; 117 ; 118)$ atau pengeringan yang disertai dengan penyusutan dan densifikasi. Ketika cairan dikeluarkan dari gel, ada beberapa hal yang mungkin terjadi. Apabila cairan dalam gel digantikan oleh udara maka akan terjadi perubahan besar pada struktur jaringan. Jika gel dikeringkan dengan penguapan maka jaringan gel akan runtuh dan menghasilkan xerogel $(119 ; 120)$. Jika pengeringan terjadi pada kondisi superkritis, maka struktur jaringan dapat dipertahankan, dan akan membentuk gel dengan pori-pori(121) yang besar yang disebut aerogel $(25 ; 26 ; 122 ; 123)$.

Pada proses penghapusan sisa pelarut tersebut sangat dipengaruhi oleh distribusi porositas dalam gel tersebut. Proses drying ini dilakukan dengan cara menguapkan larutan . untuk mendapatkan struktur sol gel yang memiliki luas permukaan yang tinggi maka cairan tidak didinginkan.

Untuk mendukung polikondensasi lebih lanjut dan untuk meningkatkan sifat mekanik serta stabilitas struktural gel, maka diperlukan proses pembakaran melalui tahap sintering akhir, densifikasi, dan pertumbuhan butir.

Untuk mendapatkan suatu prekursor(124-129) sol dengan kualitas yang baik, maka prekursor sol tersebut diletakkan di atas substrat yang akan menghasilkan sebuah film(105; $130-132)$ misalnya dengan dip-coating $(133 ; 134)$ atau spin coating $(135 ; 136)$ dengan cara dilemparkan ke dalam sebuah wadah yang sesuai dengan bentuk atau model yang kita inginkan misalnya keramik, gelas, dan aerogels. Metode sol gel ini dapat diterapkan dalam bidang optik, elektronik, energi, ruang, biosensor(137-141), serta obat.

\section{c. Penerapan sol gel}

Ada banyak produk-produk yang dapat dihasilkan melalui metode sol-gel ini. Para ilmuan telah menggunakan metode ini untuk membuat bahan-bahan atau material yang ringan dan beberapa karamik yang paling sulit. Aplikasi sol-gel ini paling banyak pada pembuatan film tipis(94; 112; 142-144) yang dapat diproduksi di atas sepotong substrat dengan spin-coating atau dip-coating.

1. Film tipis dan serat

Dengan mengatur viskositas suatu larutan dalam suatu kisaran yang tepat, maka kita dapat menarik serat $(13 ; 145-154)$ optik dan serat keramik tahan api yang dapat digunakan untuk sensor serat optik dan insulasi termal. Sehingga banyak ditemukan bahan keramik, baik dari kaca maupun dari kristal yang digunakan dalam berbagai bentuk dari komponen dalam keadaan padat seperti film, pelapis dan serat. 


\section{Serbuk nanoscale}

Melalui presipitasi kita dapat membuat bubuk keramik ultrahalus $(155 ; 156)$ dan seragam Bubuk dengan komposisi tunggal dan ganda dibuat dengan ukuran partikel skala nano yang dapat diaplikasikan pada gigi dan biomedis. Serbuk komposit(60; 121; 157-162) digunakan sebagai agrokimia dan herbisida. Bubuk abasif digunakan dalam berbagai finishing operasi. Metode sol-gel ini juga dapat digunakan untuk sintesis zeolit. Dengan metode sol-gel, elemen logam atau logam oksida akan mudah dimasukkan ke dalam produk atau hasil akhir dan sol silikat.

Pruduk lain yang dapat dibuat dengan metode sol-gel ini termasuk berbagai membrane keramik untuk microfiltration(163; 164), ultrafiltration, nanofiltration, pervaporation, dan reverse osmosis.

3. Opto-mechanical

Melalui rute sol-gel, dapat dibuat unsur optik makroskopis, komponen optik(70; 73; $74 ; 110 ; 113 ; 165-171)$ aktif serta cermin(172) luas area panas, lensa, dan pemisah berkas dengan cepat dan biaya yang dibutuhkan lebih rendah(173).

4. Obat

Alumina(92; 174; 175) yang yang dibuat menggunakan proses sol-gel dapat digunakan sebagai pembawa obat dan juga sebagai penyembuh luka.

Ada beberapa keunggulan dari teknik $(91 ; 92 ; 134 ; 145 ; 157 ; 167 ; 176)$ sol gel diantaranya homogenitas hasil yang tinggi, senyawa yang dihasilkan memiliki kemurnian yang tinggi, dan suhu yang digunakan relatif rendah(177).

Diantara keunggulan dari teknik sol gel tadi, ada juga beberapa kelemahan dari teknik sol gel antara lain, prekursor yang digunakan mahal, waktu yang dibutuhkan lama, dan menghasilkan zat sisa berupa hidroksil dan karbon(178).

\section{Kesimpulan}

Berdasarkan literatur dapat disimpulkan bahwa proses sol gel merupakan metode sintesis nanopartikel dengan menggunakan dua tahapan fase yaitu sol dan gel. Sol merupakan suatu suspensi koloid dimana fasa terdispersinya berupa zat padat dan pendispersinya berupa zat cair. Sedangkan gel merupakan suatu zat yang memiliki pori semirigid yang terdiri dari jaringan kontinu dalam tiga dimensi yang terbentuk dari rantai polimer Metode sol gel akan menghasilkan suatu material berupa keramik,gelas. Dengan menggunakan metode sol gel ini akan memungkinkan membentuk ukuran partikel skala nano sekaligus membentuk penampakan morfologi yang homogen.

\section{Referensi}

1. Zemtsova EG, Arbenin AY, Yudintceva NM, Valiev RZ, Orekhov EV, Smirnov VM. 2017. Bioactive Coating with Two-Layer Hierarchy of Relief Obtained by Sol-Gel Method with Shock Drying and Osteoblast Response of Its Structure. Nanomaterials 7

2. Ben-Arfa BA, Salvado IM, Ferreira JM, Pullar RC. 2017. Novel route for rapid sol-gel synthesis of hydroxyapatite, avoiding ageing and using fast drying with a 50-fold to 200 -fold reduction in process time. Materials science \& engineering. C, Materials for biological applications 70:796-804

3. Mercade-Prieto R, Gunasekaran S. 2009. Alkali cold gelation of whey proteins. Part I: sol-gel-sol(-gel) transitions. Langmuir : the ACS journal of surfaces and colloids 25:5785-92 
4. Pannier A, Mkandawire M, Soltmann U, Pompe W, Bottcher H. 2012. Biological activity and mechanical stability of sol-gel-based biofilters using the freeze-gelation technique for immobilization of Rhodococcus ruber. Applied microbiology and biotechnology 93:1755-67

5. Holder AJ, Badiei N, Hawkins K, Wright C, Williams PR, Curtis DJ. 2018. Control of collagen gel mechanical properties through manipulation of gelation conditions near the sol-gel transition. Soft matter 14:574-80

6. Zaidi NA, Tahir MW, Vellekoop MJ, Lang W. 2018. Design of Novel Ceramic Preconcentrator and Integration in Gas Chromatographic System for Detection of Ethylene Gas from Ripening Bananas. Sensors 18

7. Zhao YH, Zhang KC, Wang ZW, Huang P, Zhu K, et al. 2017. Comprehensive Study of Sol-Gel versus Hydrolysis-Condensation Methods To Prepare ZnO Films: Electron Transport Layers in Perovskite Solar Cells. ACS applied materials \& interfaces 9:26234-41

8. Escobar S, Bernal C, Mesa M. 2015. Relationship between sol-gel conditions and enzyme stability: a case study with beta-galactosidase/silica biocatalyst for whey hydrolysis. Journal of biomaterials science. Polymer edition 26:1126-38

9. Donato RK, Lavorgna M, Musto P, Donato KZ, Jager A, et al. 2015. The role of ether-functionalized ionic liquids in the sol-gel process: effects on the initial alkoxide hydrolysis steps. Journal of colloid and interface science 447:77-84

10. Ozyilmaz E, Sayin S, Arslan M, Yilmaz M. 2014. Improving catalytic hydrolysis reaction efficiency of sol-gel-encapsulated Candida rugosa lipase with magnetic beta-cyclodextrin nanoparticles. Colloids and surfaces. B, Biointerfaces 113:182-9

11. Du T, Li H, Sant G, Bauchy M. 2018. New insights into the sol-gel condensation of silica by reactive molecular dynamics simulations. The Journal of chemical physics 148:234504

12. Wu J, Yuan J, Ye B, Wu Y, Xu Z, et al. 2018. Dual-Responsive Core Crosslinking Glycopolymer-Drug Conjugates Nanoparticles for Precise Hepatocarcinoma Therapy. Frontiers in pharmacology 9:663

13. Wu X, Liu A, Wang W, Ye R. 2018. Improved mechanical properties and thermal-stability of collagen fiber based film by crosslinking with casein, keratin or SPI: Effect of crosslinking process and concentrations of proteins. International journal of biological macromolecules 109:1319-28

14. Yang M, Liu W, Jiang C, He S, Xie Y, Wang Z. 2018. Fabrication of superhydrophobic cotton fabric with fluorinated $\mathrm{TiO} 2$ sol by a green and one-step sol-gel process. Carbohydrate polymers 197:75-82

15. Xia W, Wu H, Xue P, Zhu X. 2018. Microstructural, Magnetic, and Optical Properties of Pr-Doped Perovskite Manganite La0.67Ca0.33MnO3 Nanoparticles Synthesized via Sol-Gel Process. Nanoscale research letters 13:135

16. Chen QZ, Li Y, Jin LY, Quinn JM, Komesaroff PA. 2010. A new sol-gel process for producing Na(2)Ocontaining bioactive glass ceramics. Acta biomaterialia 6:4143-53

17. Asaro F, Benedetti A, Freris I, Riello P, Savko N. 2010. Evolution of the nonionic inverse microemulsion-acid-TEOS system during the synthesis of nanosized silica via the sol-gel process. Langmuir : the ACS journal of surfaces and colloids 26:12917-25

18. $\mathrm{He} \mathrm{H}$, Xiao D, He J, Li H, He H, et al. 2014. Preparation of a core-shell magnetic ion-imprinted polymer via a sol-gel process for selective extraction of $\mathrm{Cu}$ (II) from herbal medicines. The Analyst 139:2459-66

19. Chang YC, Lee CY, Chiu HT. 2014. Porous inorganic materials from living porogens: channel-like $\mathrm{TiO} 2$ from yeast-assisted sol-gel process. ACS applied materials \& interfaces 6:31-5

20. Otsuka T, Maeda T, Hotta A. 2014. Effects of salt concentrations of the aqueous peptide-amphiphile solutions on the sol-gel transitions, the gelation speed, and the gel characteristics. The journal of physical chemistry. $B$ 118:11537-45

21. Li X, Kong X, Wang X, Shi S, Guo G, et al. 2010. Gel-sol-gel thermo-gelation behavior study of chitosan-inorganic phosphate solutions. European journal of pharmaceutics and biopharmaceutics : official journal of Arbeitsgemeinschaft fur Pharmazeutische Verfahrenstechnik e.V 75:388-92

22. Shang MY, Cao LH, Liu M, Luo X, Ren HB, et al. 2013. [Study on the preparation and properties of novel silica microporous antireflective coating by sol-gel process]. Guang pu xue yu guang pu fen xi= Guang 
23. Seeni Meera KM, Murali Sankar R, Jaisankar SN, Mandal AB. 2013. Physicochemical studies on polyurethane/siloxane cross-linked films for hydrophobic surfaces by the sol-gel process. The journal of physical chemistry. B 117:2682-94

24. Rezaei A, Mohammadi MR. 2013. In vitro study of hydroxyapatite/polycaprolactone (HA/PCL) nanocomposite synthesized by an in situ sol-gel process. Materials science \& engineering. $C$, Materials for biological applications 33:390-6

25. Kersen U, Keiski R. 2005. Characterization of La2Mo2O9 aerogels synthesized by the sol-gel chemistry and high-temperature supercritical drying. Journal of nanoscience and nanotechnology 5:1734-6

26. Kong Y, Jiang G, Fan M, Shen X, Cui S, Russell AG. 2014. A new aerogel based CO2 adsorbent developed using a simple sol-gel method along with supercritical drying. Chemical communications 50:12158-61

27. Ganasen P, Khan MR, Kalam MA, Mahmud MS. 2014. Effect of visible light on catalytic hydrolysis of p-nitrophenyl palmitate by the Pseudomonas cepacia lipase immobilized on sol-gel support. Bioprocess and biosystems engineering 37:2353-9

28. Ungurean M, Paul C, Peter F. 2013. Cellulase immobilized by sol-gel entrapment for efficient hydrolysis of cellulose. Bioprocess and biosystems engineering 36:1327-38

29. Figueira JA, Sato HH, Fernandes P. 2013. Establishing the feasibility of using beta-glucosidase entrapped in Lentikats and in sol-gel supports for cellobiose hydrolysis. Journal of agricultural and food chemistry 61:626-34

30. Yilmaz E. 2012. Enantioselective enzymatic hydrolysis of racemic drugs by encapsulation in sol-gel magnetic sporopollenin. Bioprocess and biosystems engineering 35:493-502

31. Soares CM, de Castro HF, Itako JE, de Moraes FF, Zanin GM. 2005. Characterization of sol-gel bioencapsulates for ester hydrolysis and synthesis. Applied biochemistry and biotechnology 121124:845-59

32. Liu DM, Troczynski T, Hakimi D. 2002. Effect of hydrolysis on the phase evolution of water-based solgel hydroxyapatite and its application to bioactive coatings. Journal of materials science. Materials in medicine 13:657-65

33. Cho MS, Kim BH, Hwang YM, Woo HG, Kim DH. 2006. Dry sol-gel condensation of p-X-C6H4SiH3 $(\mathrm{X}=\mathrm{H}, \mathrm{CH} 3, \mathrm{CH} 3 \mathrm{O}, \mathrm{F}, \mathrm{Cl})$ to organosilica p-X-C6H4SiO3 using nickelocene. Journal of nanoscience and nanotechnology 6:3388-91

34. Pattier B, Henderson M, Brotons G, Gibaud A. 2010. Study of titanium oxide sol-gel condensation using small angle X-ray scattering. The journal of physical chemistry. B 114:5227-32

35. PUTRI ADC. 2017. SINTESIS DAN KARAKTERISASI SERBUK ZrSiO4 DENGAN METODE SOLGE.

36. Tursibadi s. 2000. Pembuatan Keramik Kordierit Dengan Metode Sol-Gel Dan Karakterisasinya

37. Rizky Bimanda Sakti AS, Heri Susanto. 2011. Sintwsis Lapisan Tipis Nanokomposit TiO2 CNT Menggunakan Metode Sol Gel Dan Aplikasinya Untuk Fotodegradssi Zat Warna Azo Orange 3R.

38. Huang S, Dakhchoune M, Luo W, Oveisi E, He G, et al. 2018. Single-layer graphene membranes by crack-free transfer for gas mixture separation. Nature communications 9:2632

39. I.Joni d. 2014. Penerapan Metode Sol-Gel dengan Variasi Temperatur dan Waktu Kalsinasi pada Sintesis Barium M-Heksaferit (BaFe12O19) fisika dan aplikasinya 10

40. Septina W. 2007. Sintesa Nanokristal Mersopori TiO2 Dengan Metode Sol Gel.

41. Shea KJ, Loy DA. 2001. A mechanistic investigation of gelation. The sol-gel polymerization of precursors to bridged polysilsesquioxanes. Accounts of chemical research 34:707-16

42. Rolan Rusli IA, Aep Patah. 2012. Sintesis Oksida Bi2Fex v1-xo5,5-3x2 Dengan Metode Sol Gel Dan Reaksi Kimia Padat.

43. Khalesi Moghaddam R, Goharpey F, Khademzadeh Yeganeh J. 2018. Interplay between phase separation and dewetting in PS/PVME thin films: effect of temperature. Soft matter 14:6684-95

44. Aditama SN. 2015. Sintesis dan Karakterisasi Zeolit X dari Abu Vulkanik Gunung Kelud dengan Variasi SuhuHidrotermal Menggunakan Metode Sol Gel.

45. Khakalo K, Baumgarten K, Tighe BP, Puisto A. 2018. Coarsening and mechanics in the bubble model $\begin{array}{lllll}\text { for wet } & \text { foams. } & \text { Physical } & \text { review. }\end{array}$ 
46. Gabrielli L, Russo L, Poveda A, Jones JR, Nicotra F, et al. 2013. Epoxide opening versus silica condensation during sol-gel hybrid biomaterial synthesis. Chemistry 19:7856-64

47. Endah Yuniarti JT. 2013. Pengaruh pH, Suhu Dan Waktu Pada Sintesis Lifepo4/C Dengan Metode Sol Gel Sebagai Material Katoda Untuk Baterai Sekunder Lithium.

48. Sari BT. 2016. SINTESIS NANOPARTIKEL PbS MELALUI METODE SOL-GEL DENGAN EDTA SEBAGAI CAPPING AGENT.

49. Atta NF, Hamed MM, Abdel-Mageed AM. 2010. Computational investigation and synthesis of a sol-gel imprinted material for sensing application of some biologically active molecules. Analytica chimica acta 667:63-70

50. Ramesh S, Kim HS, Lee YJ, Hong GW, Kim JH. 2017. Erratum to Nanostructured Silica/GoldCellulose-Bonded Amino-POSS Hybrid Composite via Sol-Gel Process and Its Properties. Nanoscale research letters 12:458

51. Xiumei H, Xin Y, Jianquan Q, Xiwei Q, Xiaoqiang W, et al. 2016. The Photoluminescence Properties of $\mathrm{CaYAI}(3) \mathrm{O}(7): \mathrm{Ce}(3)(+), \mathrm{Tb}(3)(+), \mathrm{Sm}(3)(+)$ Prepared by the Sol-Gel Process. Journal of nanoscience and nanotechnology 16:730-3

52. Guo X, Song J, Lvlin Y, Nakanishi K, Kanamori K, Yang H. 2015. Preparation of macroporous zirconia monoliths from ionic precursors via an epoxide-mediated sol-gel process accompanied by phase separation. Science and technology of advanced materials 16:025003

53. Resende SF, Nunes EHM, Houmard M, Vasconcelos WL. 2014. Simple sol-gel process to obtain silicacoated anatase particles with enhanced $\mathrm{TiO} 2-\mathrm{SiO} 2$ interfacial area. Journal of colloid and interface science 433:211-7

54. Hofle S, Bruns M, Strassle S, Feldmann C, Lemmer U, Colsmann A. 2013. Tungsten oxide buffer layers fabricated in an inert sol-gel process at room-temperature for blue organic light-emitting diodes. Advanced materials 25:4113-6

55. Taira M, Okazaki M, Takahashi J. 1997. Characterization of 50wt\%SiO2-20wt\%P2O5-30wt\%CaO glass-ceramic powders prepared by the sol-gel process. Dental materials journal 16:117-26

56. Lee SS, Hong TW. 2014. Life Cycle Assessment for Proton Conducting Ceramics Synthesized by the Sol-Gel Process. Materials 7:6677-85

57. Beozzo CC, Alves-Rosa MA, Pulcinelli SH, Santilli CV. 2013. Liquid Foam Templates Associated with the Sol-Gel Process for Production of Zirconia Ceramic Foams. Materials 6:1967-79

58. Miao Y, Yang Z, Liang B, Li Q, Chen Q, et al. 2016. A novel in situ synthesis of SiBCN-Zr composites prepared by a sol-gel process and spark plasma sintering. Dalton transactions 45:12739-44

59. Wang J, Zhao H, Zhou S, Lu X, Feng B, et al. 2009. One-step in situ synthesis and characterization of sponge-like porous calcium phosphate scaffolds using a sol-gel and gel casting hybrid process. Journal of biomedical materials research. Part A 90:401-10

60. Milella E, Cosentino F, Licciulli A, Massaro C. 2001. Preparation and characterisation of titania/hydroxyapatite composite coatings obtained by sol-gel process. Biomaterials 22:1425-31

61. Ben-Arfa BAE, Fernandes HR, Miranda Salvado IM, Ferreira JMF, Pullar RC. 2018. Synthesis and bioactivity assessment of high silica content quaternary glasses with $\mathrm{Ca}$ : $\mathrm{P}$ ratios of 1.5 and 1.67, made by a rapid sol-gel process. Journal of biomedical materials research. Part A 106:510-20

62. Rezabeigi E, Wood-Adams PM, Drew RA. 2014. Synthesis of 45S5 Bioglass(R) via a straightforward organic, nitrate-free sol-gel process. Materials science \& engineering. C, Materials for biological applications 40:248-52

63. Wang J, Shaw LL. 2009. Synthesis of high purity hydroxyapatite nanopowder via sol-gel combustion process. Journal of materials science. Materials in medicine 20:1223-7

64. Li FL, Zhang HJ. 2017. Synthesis of Hollow Sphere and 1D Structural Materials by Sol-Gel Process. Materials 10

65. Nakonieczny D, Paszenda Z, Drewniak S, Radko T, Lis M. 2016. sZrO2-CeO2 ceramic powders obtained from a sol-gel process using acetylacetone as a chelating agent for potential application in prosthetic dentistry. Acta of bioengineering and biomechanics 18:53-60

66. Liu DM, Troczynski T, Tseng WJ. 2001. Water-based sol-gel synthesis of hydroxyapatite: process development. Biomaterials

22:1721-30 
67. Agustin-Saenz C, Machado M, Tercjak A. 2018. Antireflective mesoporous silica coatings by optimization of water content in acid-catalyzed sol-gel method for application in glass covers of concentrated photovoltaic modules. Journal of colloid and interface science 534:370-80

68. Ferrari JL, Limal KO, Maia LJ, Ribeiro SJ, Gomes AS, Goncalves RR. 2011. Broadband NIR emission in sol-gel $\mathrm{Er}(3+)$-activated $\mathrm{SiO} 2-\mathrm{Ta} 2 \mathrm{O} 5$ glass ceramic planar and channel waveguides for optical application. Journal of nanoscience and nanotechnology 11:2540-4

69. Li G, Nogami M, Abe Y. 1995. Defect formation and evolution in TeO2-containing borosilicate glass films derived from a sol-gel process. Physical review. B, Condensed matter 51:14930-5

70. Rajamannan B, Mugundan S, Viruthagiri G, Praveen P, Shanmugam N. 2014. Linear and nonlinear optical studies of bare and copper doped TiO2 nanoparticles via sol gel technique. Spectrochimica acta.

Part A, Molecular and biomolecular spectroscopy 118:651-6

71. Yahya N, Al Habashi RM, Koziol K, Borkowski RD, Akhtar MN, et al. 2011. Morphology and magnetic characterisation of aluminium substituted yttrium-iron garnet nanoparticles prepared using sol gel technique. Journal of nanoscience and nanotechnology 11:2652-6

72. Herrera G, Montoya N, Domenech-Carbo A, Alarcon J. 2013. Synthesis, characterization and electrochemical properties of iron-zirconia solid solution nanoparticles prepared using a sol-gel technique. Physical chemistry chemical physics : PCCP 15:19312-21

73. Ricco R, Nizzero S, Penna E, Meneghello A, Cretaio E, Enrichi F. 2018. Ultra-small dye-doped silica nanoparticles via modified sol-gel technique. Journal of nanoparticle research : an interdisciplinary forum for nanoscale science and technology 20:117

74. Ba-Abbad MM, Kadhum AA, Mohamad AB, Takriff MS, Sopian K. 2013. Visible light photocatalytic activity of $\mathrm{Fe}(3+)$-doped $\mathrm{ZnO}$ nanoparticle prepared via sol-gel technique. Chemosphere 91:1604-11

75. Zhang J, Nie J, Zhu X. 2018. Surface-Selective Grafting of Crosslinking Layers on Hydrogel Surfaces via Two Different Mechanisms of Photopolymerization for Site-Controllable Release. Macromolecular rapid communications:e1800144

76. Silva CR, Airoldi C. 1997. Acid and Base Catalysts in the Hybrid Silica Sol-Gel Process. Journal of colloid and interface science 195:381-7

77. Wang J, Wu Z, Wang G, Matyjaszewski K. 2018. In Situ Crosslinking of Nanoparticles in Polymerization-Induced Self-Assembly via ARGET ATRP of Glycidyl Methacrylate. Macromolecular rapid communications:e1800332

78. Catauro M, Tranquillo E, Illiano M, Sapio L, Spina A, Naviglio S. 2017. The Influence of the Polymer Amount on the Biological Properties of $\mathrm{PCL} / \mathrm{ZrO}(2)$ Hybrid Materials Synthesized via Sol-Gel Technique. Materials 10

79. Catauro M, Papale F, Roviello G, Ferone C, Bollino F, et al. 2014. Synthesis of $\mathrm{SiO}(2)$ and $\mathrm{CaO}$ rich calcium silicate systems via sol-gel process: bioactivity, biocompatibility, and drug delivery tests. Journal of biomedical materials research. Part A 102:3087-92

80. Lourenco R, Linhares AAN, de Oliveira AV, da Silva MG, de Oliveira JG, Canela MC. 2017. Photodegradation of ethylene by use of $\mathrm{TiO} 2$ sol-gel on polypropylene and on glass for application in the postharvest of papaya fruit. Environmental science and pollution research international 24:6047-54

81. Arif Yasthopi Rahadian Zainul AA, Hermansyah Aziz, Syukri Arief, Syukri. 2015. Photoelectrosplitting Water for Hydrogen Production Using Illumination with Indoor Lights. Journal of Chemical and Pharmaceutical Research

82. Zhu H, Jing Y, Pal M, Liu Y, Liu Y, et al. 2017. Mesoporous TiO2@N-doped carbon composite nanospheres synthesized by the direct carbonization of surfactants after sol-gel process for superior lithium storage. Nanoscale 9:1539-46

83. Zainul R. 2018. Design and Modification of Copper Oxide Electrodes for Improving Conversion Coefficient Indoors Lights (PV-Cell) Photocells. CC-By Attribution 4.0 International

84. Mayo EI, Poore DD, Stiegman AE. 2000. Catalysis of the silica sol-gel process by divalent transition metal bis(acetylacetonate) complexes. Inorganic chemistry 39:899-905

85. Chen Z, Hobo T. 2001. Chemically L-phenylalaninamide-modified monolithic silica column prepared by a sol-gel process for enantioseparation of dansyl amino acids by ligand exchange-capillary electrochromatography. Analytical chemistry 73:3348-57 
86. Chen Z, Uchiyama K, Hobo T. 2002. Chemically modified chiral monolithic silica column prepared by a sol-gel process for enantiomeric separation by micro high-performance liquid chromatography. Journal of chromatography. A 942:83-91

87. Hamza K, Abu-Reziq R, Avnir D, Blum J. 2004. Heck vinylation of aryl iodides by a silica sol-gel entrapped $\mathrm{Pd}(\mathrm{II})$ catalyst and its combination with a photocyclization process. Organic letters 6:925-7

88. Rahadian Zainul AA, Hermansyah Aziz, Syukri Arief, Syukri Darajat. 2015. Modifikasi dan Karakteristik I-V Sel Fotovoltaik Cu2O/Cu-Gel Na2SO4 Melalui Illuminasi Lampu Neon. EKSAKTA Berkala Ilmiah Bidang MIPA

89. Rahadian Zainul AA, Hermansyah Aziz, Syukri Arief, Syukri Darajat. 2015. Disain Geometri Reaktor Fotosel Cahaya Ruang. Jurnal Riset Kimia

90. Desy Kurniawati IL, Salmariza Sy Harmiwati, Zulkarnain Chaidir, Edison Munaf, Rahmiana Zein, Hermansyah Aziz, Rahadian Zainul. 2015. Biosorption of Pb (II) from Aqueous Solutions Using Column Method by Lengkeng (Euphoria logan lour) Seed and Shell. Journal of Chemical and Pharmaceutical Research

91. Catauro M, Papale F, Bollino F, Gallicchio M, Pacifico S. 2014. Biological evaluation of zirconia/PEG hybrid materials synthesized via sol-gel technique. Materials science \& engineering. $C$, Materials for biological applications 40:253-9

92. Madani A, Nakhaei M, Karami P, Rajabzadeh G, Salehi S, Bagheri H. 2016. Sol-gel dip coating of yttria-stabilized tetragonal zirconia dental ceramic by aluminosilicate nanocomposite as a novel technique to improve the bonding of veneering porcelain. International journal of nanomedicine $11: 3215-23$

93. Chepurna I, Smotraev R, Kanibolotsky V, Strelko V. 2011. Colloidal and chemical aspects of nanosized hydrated zirconium dioxide synthesized via a sol-gel process. Journal of colloid and interface science 356:404-11

94. Stawski TM, Veldhuis SA, Castricum HL, Keim EG, Eeckhaut G, et al. 2011. Development of nanoscale inhomogeneities during drying of sol-gel derived amorphous lead zirconate titanate precursor thin films. Langmuir : the ACS journal of surfaces and colloids 27:11081-9

95. Aronne A, Sannino F, Bonavolonta SR, Fanelli E, Mingione A, et al. 2012. Use of a new hybrid sol-gel zirconia matrix in the removal of the herbicide MCPA: a sorption/degradation process. Environmental science \& technology 46:1755-63

96. Dhayal V, Chaudhary A, Choudhary BL, Nagar M, Bohra R, et al. 2012. Molecular precursors for the preparation of homogenous zirconia-silica materials by hydrolytic sol-gel process in organic media. Crystal structures of $[\mathrm{Zr}\{\mathrm{OSi}(\mathrm{O}(\mathrm{t}) \mathrm{Bu}) 3\} 4(\mathrm{H} 2 \mathrm{O}) 2] .2 \mathrm{H} 2 \mathrm{O}$ and $[\mathrm{Ti}(\mathrm{O}(\mathrm{t}) \mathrm{Bu})\{\mathrm{OSi}(\mathrm{O}(\mathrm{t}) \mathrm{Bu}) 3\} 3]$. Dalton transactions 41:9439-50

97. Zhang Y, Hu X, Wang SW, Zhang B, Shi L, et al. 2018. High transparent mid-infrared silicon "window" decorated with amorphous photonic structures fabricated by facile phase separation. Optics express 26:18734-48

98. Fonblanc D, Lopez-Ferber D, Wynn M, Lale A, Soleilhavoup A, et al. 2018. Crosslinking chemistry of poly(vinylmethyl-co-methyl)silazanes toward low-temperature formable preceramic polymers as precursors of functional aluminium-modified Si-C-N ceramics. Dalton transactions

99. Stotesbury T, Illes M, Wilson P, Vreugdenhil AJ. 2017. The application of silicon sol-gel technology to forensic blood substitute development: Mimicking aspects of whole human blood rheology. Forensic science international 270:12-9

100. Vishwas M, Narasimha Rao K, Arjuna Gowda KV, Chakradhar RP. 2012. Influence of Sn doping on structural, optical and electrical properties of $\mathrm{ZnO}$ thin films prepared by cost effective sol-gel process. Spectrochimica acta. Part A, Molecular and biomolecular spectroscopy 95:423-6

101. Jun MC, Koh JH. 2013. Optical and structural properties of Al-doped ZnO thin films by sol gel process. Journal of nanoscience and nanotechnology 13:3403-7

102. Wang Y, Zeng Z, Guan N, Cheng J. 2001. Sol-gel technique for the preparation of beta-cyclodextrin derivative stationary phase in open-tubular capillary electrochromatography. Electrophoresis 22:216772 
103. Pinjari DV, Prasad K, Gogate PR, Mhaske ST, Pandit AB. 2015. Synthesis of titanium dioxide by ultrasound assisted sol-gel technique: effect of calcination and sonication time. Ultrasonics sonochemistry 23:185-91

104. Li H, Zhang Y, Wang S, Wu Q, Liu C. 2009. Study on nanomagnets supported TiO2 photocatalysts prepared by a sol-gel process in reverse microemulsion combining with solvent-thermal technique. Journal of hazardous materials 169:1045-53

105. Zhong P, Que W, Zhang J. 2010. Fabrication of regular TiO2 nanoporous films derived by combining nanoimprint technique with sol-gel method. Journal of nanoscience and nanotechnology 10:7574-7

106. Wu Z, Cao Z, Zeng JL, Zhang L, Chu X, et al. 2010. A reusable capacitive immunosensor based on a $\mathrm{CuS}$ ultrathin film constructed by using a surface sol-gel technique. Analytical sciences : the international journal of the Japan Society for Analytical Chemistry 26:1001-6

107. Tatte T, Kolesnikova AL, Hussainov M, Talviste R, Lohmus R, et al. 2010. Crack formation during post-treatment of nano- and microfibres prepared by sol-gel technique. Journal of nanoscience and nanotechnology 10:6009-16

108. Prasad K, Pinjari DV, Pandit AB, Mhaske ST. 2010. Phase transformation of nanostructured titanium dioxide from anatase-to-rutile via combined ultrasound assisted sol-gel technique. Ultrasonics sonochemistry 17:409-15

109. Prasad K, Pinjari DV, Pandit AB, Mhaske ST. 2010. Synthesis of titanium dioxide by ultrasound assisted sol-gel technique: effect of amplitude (power density) variation. Ultrasonics sonochemistry 17:697-703

110. Kamaruddin SA, Chan KY, Sahdan MZ, Rusop M, Saim H. 2010. ZnO microstructures and nanostructures prepared by sol-gel hydrothermal technique. Journal of nanoscience and nanotechnology 10:5618-22

111. Dubey P, Choi SK, Choi JH, Shin DH, Lee CJ. 2010. High-quality thin-multiwalled carbon nanotubes synthesized by $\mathrm{Fe}-\mathrm{Mo} / \mathrm{MgO}$ catalyst based on a sol-gel technique: synthesis, characterization, and field emission. Journal of nanoscience and nanotechnology 10:3998-4006

112. Shimizu W, Nakamura S, Sato T, Murakami Y. 2012. Creation of high-refractive-index amorphous titanium oxide thin films from low-fractal-dimension polymeric precursors synthesized by a sol-gel technique with a hydrazine monohydrochloride catalyst. Langmuir : the ACS journal of surfaces and colloids 28:12245-55

113. Shimizu W, Sato T, Matsumoto T, Murakami Y. 2012. Rapid synthesis of low-fractal dimension titanium oxide polymers by a sol-gel technique using hydrazine monohydrochloride. Journal of nanoscience and nanotechnology 12:3732-8

114. Jeong HJ, Kim DK, Lee SB, Kwon SH, Kadono K. 2001. Preparation of Water-Repellent Glass by SolGel Process Using Perfluoroalkylsilane and Tetraethoxysilane. Journal of colloid and interface science 235:130-4

115. Pipattanawarothai A, Suksai C, Srisook K, Trakulsujaritchok T. 2017. Non-cytotoxic hybrid bioscaffolds of chitosan-silica: Sol-gel synthesis, characterization and proposed application. Carbohydrate polymers 178:190-9

116. Catauro M, Bollino F, Papale F, Gallicchio M, Pacifico S. 2015. Influence of the polymer amount on bioactivity and biocompatibility of $\mathrm{SiO} 2 / \mathrm{PEG}$ hybrid materials synthesized by sol-gel technique. Materials science \& engineering. C, Materials for biological applications 48:548-55

117. Wang B, Friess W. 2017. Spray drying of silica microparticles for sustained release application with a new sol-gel precursor. International journal of pharmaceutics 532:281-8

118. Pei L, Kurumada K, Tanigaki M, Hiro M, Susa K. 2005. Effect of drying on the mesoporous structure of sol-gel derived silica with PPO-PEO-PPO template block copolymer. Journal of colloid and interface science 284:222-7

119. Jun SH, Lee EJ, Yook SW, Kim HE, Kim HW, Koh YH. 2010. A bioactive coating of a silica xerogel/chitosan hybrid on titanium by a room temperature sol-gel process. Acta biomaterialia 6:302-7

120. Pohorilyi RP, Honcharyk VP, Kozhara LI, Zub Iu L, Chuiko OO. 2006. [Comparative characteristic of activity of urease, incorporated into polysiloxane hydrogels and xerogels, obtained by sol-gel technique].

Ukrains'kyi biokhimichnyi zhurnal 78:94-101 
121. Chu SZ, Inoue S, Wada K, Li D, Haneda H, Awatsu S. 2003. Highly Porous (TiO2-SiO2$\mathrm{TeO} 2) / \mathrm{Al} 2 \mathrm{O} 3 / \mathrm{TiO} 2$ Composite Nanostructures on Glass with Enhanced Photocatalysis Fabricated by Anodization and Sol-Gel Process. The journal of physical chemistry. B 107:6586-9

122. Bakierska M, Chojnacka A, Swietoslawski M, Natkanski P, Gajewska M, et al. 2017. Multifunctional Carbon Aerogels Derived by Sol-Gel Process of Natural Polysaccharides of Different Botanical Origin. Materials 10

123. Wei TY, Chen CH, Chien HC, Lu SY, Hu CC. 2010. A cost-effective supercapacitor material of ultrahigh specific capacitances: spinel nickel cobaltite aerogels from an epoxide-driven sol-gel process. Advanced materials 22:347-51

124. Li F, Jiang H, Zhang S. 2007. An ion-imprinted silica-supported organic-inorganic hybrid sorbent prepared by a surface imprinting technique combined with a polysaccharide incorporated sol-gel process for selective separation of cadmium(II) from aqueous solution. Talanta 71:1487-93

125. Jia WZ, Wang K, Zhu ZJ, Song HT, Xia XH. 2007. One-step immobilization of glucose oxidase in a silica matrix on a Pt electrode by an electrochemically induced sol-gel process. Langmuir : the ACS journal of surfaces and colloids 23:11896-900

126. Chen W, Oh S, Ong AP, Oh N, Liu Y, et al. 2007. Antibacterial and osteogenic properties of silvercontaining hydroxyapatite coatings produced using a sol gel process. Journal of biomedical materials research. Part A 82:899-906

127. Boettcher SW, Fan J, Tsung CK, Shi Q, Stucky GD. 2007. Harnessing the sol-gel process for the assembly of non-silicate mesostructured oxide materials. Accounts of chemical research 40:784-92

128. Alvarez GS, Desimone MF, Diaz LE. 2007. Immobilization of bacteria in silica matrices using citric acid in the sol-gel process. Applied microbiology and biotechnology 73:1059-64

129. Vidinha P, Augusto V, Almeida M, Fonseca I, Fidalgo A, et al. 2006. Sol-gel encapsulation: an efficient and versatile immobilization technique for cutinase in non-aqueous media. Journal of biotechnology 121:23-33

130. Hernandez-Garcia FA, Torres-Delgado G, Castanedo-Perez R, Zelaya-Angel O. 2016. Gaseous benzene degradation by photocatalysis using $\mathrm{ZnO}+\mathrm{Zn} 2 \mathrm{TiO} 4$ thin films obtained by sol-gel process. Environmental science and pollution research international 23:13191-9

131. Guo K, Zhang R, Mou Q, Cui R, Deng C. 2016. Ferroelectric, Dielectric, Ferromagnetic, and Magnetoelectric Properties of BNF-NZF Bilayer Nanofilms Prepared via Sol-Gel Process. Nanoscale research letters 11:387

132. Xu Y, Chen CJ, Xu R, Mackenzie JD. 1991. Ferroelectric Sr0.60Ba0.40Nb2O6 thin films by the sol-gel process: Electrical and optical properties. Physical review. B, Condensed matter 44:35-41

133. Huang N, Sun C, Zhu M, Zhang B, Gong J, Jiang X. 2011. Microstructure evolution of zinc oxide films derived from dip-coating sol-gel technique: formation of nanorods through orientation attachment. Nanotechnology 22:265612

134. Catauro M, Bollino F, Veronesi P, Lamanna G. 2014. Influence of PCL on mechanical properties and bioactivity of ZrO2-based hybrid coatings synthesized by sol-gel dip coating technique. Materials science \& engineering. C, Materials for biological applications 39:344-51

135. Peng YT, Lo KF, Juang YJ. 2010. Constructing a superhydrophobic surface on polydimethylsiloxane via spin coating and vapor-liquid sol-gel process. Langmuir : the ACS journal of surfaces and colloids 26:5167-71

136. Song Y, Zheng M, Ma L, Shen W. 2010. Anisotropic growth and formation mechanism investigation of $1 \mathrm{D} \mathrm{ZnO}$ nanorods in spin-coating sol-gel process. Journal of nanoscience and nanotechnology 10:42632

137. Wang X, Han M, Bao J, Tu W, Dai Z. 2012. A superoxide anion biosensor based on direct electron transfer of superoxide dismutase on sodium alginate sol-gel film and its application to monitoring of living cells. Analytica chimica acta 717:61-6

138. Ren J, Wang L, Han X, Cheng J, Lv H, et al. 2013. Organic silicone sol-gel polymer as a noncovalent carrier of receptor proteins for label-free optical biosensor application. ACS applied materials \& interfaces 5:386-94

139. Demirkoran N, Ekinci E. 2012. Immobilization of Glucose Oxidase in GLYMO/MTEOS Sol-Gel Film for Glucose Biosensor Application. Acta chimica Slovenica 59:302-6 
140. Depagne C, Roux C, Coradin T. 2011. How to design cell-based biosensors using the sol-gel process. Analytical and bioanalytical chemistry 400:965-76

141. Li F, Chen W, Tang C, Zhang S. 2009. Development of hydrogen peroxide biosensor based on in situ covalent immobilization of horseradish peroxidase by one-pot polysaccharide-incorporated sol-gel process. Talanta 77:1304-8

142. Velten D, Eisenbarth E, Schanne N, Breme J. 2004. Biocompatible Nb2O5 thin films prepared by means of the sol-gel process. Journal of materials science. Materials in medicine 15:457-61

143. Petersen J, Brimont C, Gallart M, Schmerber G, Gilliot P, et al. 2010. Correlation of structural properties with energy transfer of Eu-doped $\mathrm{ZnO}$ thin films prepared by sol-gel process and magnetron reactive sputtering. Journal of applied physics 107:123522

144. Gomez-Pozos H, Arredondo EJL, Maldonado Alvarez A, Biswal R, Kudriavtsev Y, et al. 2016. CuDoped ZnO Thin Films Deposited by a Sol-Gel Process Using Two Copper Precursors: Gas-Sensing Performance in a Propane Atmosphere. Materials 9

145. Abbasi V, Sarafraz-Yazdi A, Amiri A, Vatani H. 2016. Determination of Aromatic Amines Using SolidPhase Microextraction Based on an Ionic Liquid-Mediated Sol-Gel Technique. Journal of chromatographic science 54:677-81

146. Franco E, Dussan R, Amu M, Navia D. 2018. Statistical Optimization of the Sol-Gel Electrospinning Process Conditions for Preparation of Polyamide 6/66 Nanofiber Bundles. Nanoscale research letters $13: 230$

147. Wang Y, Wang R, Habib E, Wang R, Zhang Q, et al. 2017. Surface modification of quartz fibres for dental composites through a sol-gel process. Materials science \& engineering. C, Materials for biological applications 74:21-6

148. Song EH, Jeong SH, Park JU, Kim S, Kim HE, Song J. 2017. Polyurethane-silica hybrid foams from a one-step foaming reaction, coupled with a sol-gel process, for enhanced wound healing. Materials science \& engineering. C, Materials for biological applications 79:866-74

149. Ramesh S, Kim JH. 2014. Synthesis of cellulose-L-tyrosine-silica hybrid nanocomposites by sol-gel process for high performance applications. Journal of nanoscience and nanotechnology 14:7558-61

150. Es'haghi Z, Sorayaei H, Samadi F, Masrournia M, Bakherad Z. 2011. Fabrication of a novel nanocomposite based on sol-gel process for hollow fiber-solid phase microextraction of aflatoxins: B1 and B2, in cereals combined with high performane liquid chromatography-diode array detection. Journal of chromatography. B, Analytical technologies in the biomedical and life sciences 879:3034-40

151. Li X, Yu M, Hou Z, Wang W, Li G, et al. 2010. Preparation and luminescence properties of $\mathrm{Lu}(2) \mathrm{O}(3): \mathrm{Eu}(3+)$ nanofibers by sol-gel/electrospinning process. Journal of colloid and interface science 349:166-72

152. Cheng Y, Zhao Y, Zhang Y, Cao X. 2010. Preparation of SrAl2O4:Eu(2+), Dy(3+) fibers by electrospinning combined with sol-gel process. Journal of colloid and interface science 344:321-6

153. Allo BA, Rizkalla AS, Mequanint K. 2010. Synthesis and electrospinning of epsilon-polycaprolactonebioactive glass hybrid biomaterials via a sol-gel process. Langmuir : the ACS journal of surfaces and colloids 26:18340-8

154. Remillard JT, Jones JR, Poindexter BD, Narula CK, Weber WH. 1999. Demonstration of a hightemperature fiber-optic gas sensor made with a sol-gel process to incorporate a fluorescent indicator. Applied optics 38:5306-9

155. Dai Z, Meiser F, Mohwald H. 2005. Nanoengineering of iron oxide and iron oxide/silica hollow spheres by sequential layering combined with a sol-gel process. Journal of colloid and interface science 288:298-300

156. Kim SH, Liu BY, Zachariah MR. 2004. Ultrahigh surface area nanoporous silica particles via an aerosol-gel process. Langmuir : the ACS journal of surfaces and colloids 20:2523-6

157. Chiappone A, Fantino E, Roppolo I, Lorusso M, Manfredi D, et al. 2016. 3D Printed PEG-Based Hybrid Nanocomposites Obtained by Sol-Gel Technique. ACS applied materials \& interfaces 8:5627-33

158. Costantini A, Luciani G, Silvestri B, Tescione F, Branda F. 2008. Bioactive poly(2hydroxyethylmethacrylate)/silica gel hybrid nanocomposites prepared by sol-gel process. Journal of biomedical materials research. Part B, Applied biomaterials 86:98-104 
159. Cannas C, Musinu A, Piccaluga G, Fiorani D, Peddis D, et al. 2006. Magnetic properties of cobalt ferrite-silica nanocomposites prepared by a sol-gel autocombustion technique. The Journal of chemical physics 125:164714

160. Shchipunov YA, Karpenko TY. 2004. Hybrid polysaccharide-silica nanocomposites prepared by the solgel technique. Langmuir : the ACS journal of surfaces and colloids 20:3882-7

161. Taira M, Toyooka H, Miyawaki H, Yamaki M. 1993. Studies on radiopaque composites containing $\mathrm{ZrO} 2-\mathrm{SiO} 2$ fillers prepared by the sol-gel process. Dental materials : official publication of the Academy of Dental Materials 9:167-71

162. Suzuki H, Taira M, Wakasa K, Yamaki M. 1991. Refractive-index-adjustable fillers for visible-lightcured dental resin composites: preparation of TiO2-SiO2 glass powder by the sol-gel process. Journal of dental research 70:883-8

163. Riegger BR, Kowalski R, Hilfert L, Tovar GEM, Bach M. 2018. Chitosan nanoparticles via highpressure homogenization-assisted miniemulsion crosslinking for mixed-matrix membrane adsorbers. Carbohydrate polymers 201:172-81

164. Marino T, Russo F, Figoli A. 2018. The Formation of Polyvinylidene Fluoride Membranes with Tailored Properties via Vapour/Non-Solvent Induced Phase Separation. Membranes 8

165. Ramanauskaite L, Snitka V. 2015. The synthesis of controlled shape nanoplasmonic silver-silica structures by combining sol-gel technique and direct silver reduction. Nanoscale research letters 10:133

166. Xu ZY, Li YH, Wang LJ. 2014. Versatile technique to functionalize optical microfibers via a modified sol-gel dip-coating method. Optics letters 39:34-6

167. Al-Khanbashi HA, Shirbeeny W, Al-Ghamdi AA, Bronstein LM, Mahmoud WE. 2014. Spectroscopic ellipsometry of $\mathrm{Zn}(1-\mathrm{x}) \mathrm{Cu}(\mathrm{x}) \mathrm{O}$ thin films based on a modified sol-gel dip-coating technique. Spectrochimica acta. Part A, Molecular and biomolecular spectroscopy 118:800-5

168. Sarkar K, Rawolle M, Herzig EM, Wang W, Buffet A, et al. 2013. Custom-made morphologies of ZnO nanostructured films templated by a poly(styrene-block-ethylene oxide) diblock copolymer obtained by a sol-gel technique. ChemSusChem 6:1414-24

169. Tao S, Jayaprakash A. 2009. Nanostructured scintillating optical fiber prepared via sol-gel technique for detecting gamma radiation. Optics letters 34:3244-6

170. He M, Yuan XC, Ngo N, Bu J, Tao S. 2003. Low-cost and efficient coupling technique using reflowed sol-gel microlens. Optics express 11:1621-7

171. He M, Yuan X, Ngo NQ, Cheong WC, Bu J. 2003. Reflow technique for the fabrication of an elliptical microlens array in sol-gel material. Applied optics 42:7174-8

172. Ochsenbein A, Chai F, Winter S, Traisnel M, Breme J, Hildebrand HF. 2008. Osteoblast responses to different oxide coatings produced by the sol-gel process on titanium substrates. Acta biomaterialia 4:1506-17

173. R Zainul BO, I Dewata, J Efendi. 2018. Thermal and Surface Evaluation on The Process of Forming a $\mathrm{Cu} 2 \mathrm{O} / \mathrm{CuO}$ Semiconductor Photocatalyst on a Thin Copper Plate. IOP Conference Series: Materials Science and Engineering

174. Kelly DN, Wakabayashi RH, Stacy AM. 2014. A modified sol-gel technique for pore size control in porous aluminum oxide nanowire templates. ACS applied materials \& interfaces 6:20122-9

175. Adam F, Chua JH. 2004. The adsorption of palmytic acid on rice husk ash chemically modified with $\mathrm{Al}(\mathrm{III})$ ion using the sol-gel technique. Journal of colloid and interface science 280:55-61

176. Catauro M, Bollino F, Papale F. 2014. Biocompatibility improvement of titanium implants by coating with hybrid materials synthesized by sol-gel technique. Journal of biomedical materials research. Part A 102:4473-9

177. Zainul R. 2015. Disain dan Modifikasi Kolektor dan Reflektor Cahaya pada Panel Sel Surya Al/Cu2OGel Na2SO4. Research Report

178. M Mawardi DD, R Zainul. 2018. Characterization of PCC Cement by Addition of Napa Soil from Subdistrict Sarilamak 50 Kota District as Alternative Additional Material for Semen Padang. IOP Conference Series: Materials Science and Engineering

179. M., Yani, S. R., \& Zainul, R. (2017, September 4). Aktivasi Tanah Napa dan Pengaruhnya Terhadap Adsorpsi Ion Timbal (II)/ Pb2+. https://doi.org/10.31227/osf.io/ps523 
180. Zainul, R., Oktavia, B., Dewata, I., \& efendi, j. (2017, February 4). Studi Dinamika Molekular dan Kinetika Reaksi pada Pembelahan Molekul Air untuk Produksi Gas Hidrogen. https://doi.org/10.31227/osf.io/876s 3

181. Zainul, R., \& Dewata, I. (2015, December 29). Determination of pH-BOD-COD and degradation in batang arau watersheds at Padang city. https://doi.org/10.31227/osf.io/efdzj

182. H., Sanjaya, H., \& Zainul, R. (2016, August 30). Synthesis and Electrical Properties of ZnO-ITO and Al-ITO thin Film by Spin Coating Technique Through Sol Gel Process.

https://doi.org/10.31227/osf.io/unrt4

183. Zainul, R. (2016, September 24). Determination of the half-life and the quantum yield of ZnO semiconductor photocatalyst in humic acid. https://doi.org/10.31227/osf.io/e8a9x

184. Zainul, R. (2016, December 18). Design and Modification of Copper Oxide Electrodes for Improving Conversion Coefficient Indoors Lights (PV-Cell) Photocells. https://doi.org/10.31227/osf.io/pgn84

185. Zainul, R., Alif, A., Aziz, H., Arief, S., \& s. (2015, October 22). Photoelectrosplitting Water Mechanism at Carbon Electrode Surface using Indoor lights. https://doi.org/10.31227/osf.io/vcxq8

186. H., Sanjaya, H., \& Zainul, R. (2016, August 30). Synthesis and Electrical Properties of ZnO-ITO and Al-ITO thin Film by Spin Coating Technique Through Sol Gel Process.

https://doi.org/10.31227/osf.io/unrt4

187. Anhar, A., Sumarmin, R., \& Zainul, R. (2016, August 30). Measurement of Glycemic Index of West Sumatera Local Rice Genotypes for Healthy Food Selection. https://doi.org/10.31227/osf.io/tgy8h

188. M., Sanjaya, H., \& Zainul, R. (2015, December 30). Characterization of napa soil and adsorption of $\mathrm{Pb}$ (II) from aqueous solutions using on column method. https://doi.org/10.31227/osf.io/t8fh9

189. chaidir, z., Fadjria, N., A., \& Zainul, R. (2016, December 5). ISOLATION AND MOLECULAR IDENTIFICATION OF FRESHWATER MICROALGAE IN MANINJAU LAKE WEST SUMATERA. https://doi.org/10.31227/osf.io/nbcuf

190. chaidir, z., Zainul, R., Nurakhbari, D., \& Salim, M. (2016, September 24). Optimization of Spirulina Platensis Culture for Antioxidant Production. https://doi.org/10.17605/OSF.IO/FD6E4 


\title{
WHAT IS HYDROTERMAL ?
}

\section{Debby Firmantia Putri" ${ }^{* 1}$ Helmi Maulina Ritonga ${ }^{2}$, Vivin Murdiati² dan Rahadian Zainul ${ }^{2}$}

${ }^{1}$ Laboratorium Kimia, FMIPA, Universitas Negeri Padang, Indonesia ${ }^{2}$ Laboratorium Kimia, FMIPA, Universitas Negeri Padang, Indonesia ${ }^{3}$ Laboratorium Kimia, FMIPA, Universitas Negeri Padang, Indonesia

${ }^{4}$ laboratorium Fisika Kimia, FMIPA, Universitas Negeri Padang, Indonesia

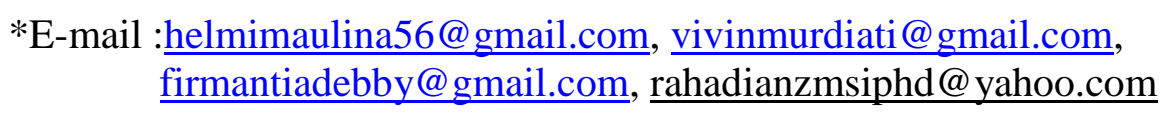

\begin{abstract}
Abstrak. Hydrothermal merupakan suatu teknik pengkristalan dari temperatur tinggi pada keadaan campuran dan tekanan tinggi. Sintesis hydrothermal dapat juga didefinisikan metode yang menggunakan panas dan air. Pada praktiknya, metode ini melibatkan pemanasan reaktan dalam wadah tertutup (autoclave) menggunakan air. Dalam wadah tertutup, tekanan meningkat dan air tetap sebagai cairan. Ada beberapa metode hydrothermal yaitu reaksi hydrothermal,hidrolisis hydrothermal, metode elektrocemical hydrothermal, reactive elektrode submerged Arc, proses mechanocemical hydrothermal, proses hydrotermal microwave, metode sonochemical hydrothermal . Tujuan mereview ini untuk mengetahui kekurangan dan kelebihan dari metode hidrotermal pada pembentukan material.
\end{abstract}

Keyword : hydrothermal, sintesis, kristal

\section{PENDAHULUAN}

Perkembangan teknologi dalam bidang material telah mengalami perkembangan yang sangat pesat dalam beberapa tahun terakhir(5). Banyak metode yang digunakan untuk pembuatan material ini, salah satunya menggunakan metode hydrothermal(6-8). Hydrothermal terbentuk dari kata hidro yang berarti air dan thermal yang berarti panas(9-11). Jadi, metode hydrothermal adalah metode yang menggunakan air dan panas yang sifatnya mengubah larutan menjadi kristal(12-14). Metode hydrothermal harus dilakukan pada sistem tertutup untuk mencegah hilangnya pelarut saat dipanaskan diatas titik didihnya(15-17).

Berdasarkan tingkat keberhasilan dalam melakukan sintesis material ada beberapa metode, tetapi dalam proses pembentukan material ini menggunakan metode hydrothermal (18; 19). Metode hydrothermal dapat menghasilkan kristalinitas dan kemurnian yang lebih tinggi $(9 ; 20 ; 21)$. Dalam beberapa penelitian metode hydrothermal dilakukan untuk meneliti suatu objek, yang dapat dilihat pada pengaruh jenis dan konsentrasi(22-24). 
Karena hal ini dapat mempengaruhi kristalinitas produk yang akan dihasilkan dari metode hydrothermal tersebut(25-27). Penelitian ini bertujuan untuk mengetahui bagaimana proses pembentukan material dengan menggunakan metode hydrothermal $(28 ; 29)$. Air karena gaya gravitasi selalu mempunyai kecenderungan untuk bergerak ke bawah, akan tetapi apabila air tersebut kontak dengan suatu sumber panas maka akan terjadi perpindahan panas sehingga temperatur air menjadi lebih tinggi dan air menjadi lebih ringan(30-37). Keadaan ini menyebabkan air yang lebih panas bergerak ke atas dan air yang lebih dingin bergerak turun ke bawah(38-43), sehingga terjadi sirkulasi air atau arus konveksi (44-46).

Mineral yang terbentuk di lingkungan hydrothermal adalah hasil presipitasi dari larutan air panas $(47 ; 48)$. Pada pelepasan material lama dan pengendapan material baru menjadi ciri aktivitas hydrothermal (49-52),serta banyak mineral pembentuk proses yang melibatkan solusi, termasuk pelapukan dan diagenesa(18; 53). Hydrothermal merupakan suatu proses pembentukan mineral yang terjadi disekitar sumber dari panas bumi didalam kulit bumi yang terjadi akibat adanya injeksi dari magma terhadap air dengan kata lain terjadi pelarutan oleh magma sisa yang bercampur dengan air tanah sehingga mengalami pengkristalan(54-59).

Larutan hydrothermal adalah cairan bertemperatur tinggi $\left(100-500^{\circ} \mathrm{C}\right)$ sisa pendinginan magma yang mampu merubah mineral yang telah ada sebelumnya dan membentuk mineral-mineral tertentu(1). Secara umum cairan sisa kristalisasi magma tersebut bersifat silika yang kaya alumina(60;61), alkali dan alkali tanah yang mengandung air dan unsur-unsur volatil (Bateman, 1981) (62; 63). Magma hidrous atau wet magma atau gampangnya magma yang memiliki kandungan $\mathrm{H}_{2} \mathrm{O}$ cukup banyak, sebenernya kandungan $\mathrm{H}_{2} \mathrm{O}$ dalam magma tersebut max adalah 6,2\%, ketika magma mendingin dan mengkristal $3 \%$ dari $\mathrm{H}_{2} \mathrm{O}$ tersebut ikut mengkristal menjadi bagian dari mineral, yaitu menjadi biotit dan hornblenda, lalu $\mathrm{H}_{2} \mathrm{O}$ sisanya nya lepas dari magma dan membentuk larutan magmatik atau larutan hydrothermal (64-66). Jadi larutan hydrothermal terbentuk pada bagian akhir dari siklus pembekuan magma $(67 ; 68)$.

Larutan hydrothermal terjadi dalam beberapa cara. Salah satunya peleburan magma yang terjadi oleh parsial basah yang mendingin dan mengkristal, air yang menyebabkan peleburan parsial basah dilepaskan(69-77). Namun tidak sebagai air murni, tetapi mengandung semua unsur yang dapat larut yang terdapat pada magma seperti $\mathrm{NaCl}$ dan unsur kimia: emas, perak, tembaga, timbal, zinc, merkuri dan molybdenum, yang tidak terikat kuarsa, feldspar, dan mineral lain dengan substitusi ion(78; 79). Suhu yang tinggi 
meningkatkan efektifitas larutan yang sangat asin ini untuk membentuk endapan mineral hydrothermal $(80 ; 81)$.

Proses hydrothermal merupakan proses pembentuk mineral yang terjadi oleh pengaruh temperatur dan tekanan yang sangat rendah, dan larutan magma yang terbentuk sebelumnya(82-85). Secara garis besar, endapan mineral hydrothermal dapat dibagi atas $[117,118]$ :

1. Endapan hypothermal, ciri-cirinya adalah :

a. Tekanan dan temperatur pembekuan relatif tinggi [112].

b. Endapan berupa urat-urat dan korok yang berasosiasi dengan intrusi dengan kedalaman yang besar $[113,114]$.

c. Asosiasi mineral berupa sulfides, misalnya Pyrite, Calcopyrite, Galena dan Spalerite serta oksida besi $(86 ; 87)$.

d. Pada intrusi Granit sering berupa endapan logam Au, Pb, Sn, W dan Z [107,108].

2. Endapan mesotermal, yang ciri-cirinya :

a. Tekanan dan temperatur yang berpengaruh lebih rendah daripada endapan hipotermal [109,110].

b. Endapannya berasosiasi dengan batuan beku asam-basa dan dekat dengan permukaan bumi [106].

c. Tekstur akibat "cavity filling" jelas terlihat, sekalipun sering mengalami proses penggantian antara lain berupa "crustification" dan "banding" (88).

d. Asosiasi mineralnya berupa sulfide, misalnya $\mathrm{Au}, \mathrm{Cu}, \mathrm{Ag}, \mathrm{Sb}$ dan Oksida $\mathrm{Sn}$ $[115,116]$.

e. Proses pengayaan sering terjadi, (89-95).

3. Endapan epitermal, ciri-cirinya sebagai berikut :

a. Tekanan dan temperatur yang berpengaruh paling rendah[105].

b. Tekstur penggantian tidak luas (jarang terjadi) [104].

c. Endapan bisa dekat atau pada permukaan bumi [119-120].

d. Kebanyakan teksturnya berlapis atau berupa (fissure-vein) $(96 ; 97)$.

e. Struktur khas yang sering terjadi adalah "cockade structure"[111].

f. Asosiasi mineral logamnya berupa Au dan Ag dengan mineral "gangue"-nya berupa Kalsite dan Zeolit disamping Kuarsa(98). 
Adapun bentuk-bentuk endapan mineral dapat dijumpai sebagai proses endapan hydrothermal adalah sebagai Cavity filling $(99 ; 100)$. Cavity filling adalah proses mineralisasi berupa pengisian ruang-ruang bukaan (rongga) dalam batuan yang terdiri atas mineralmineral yang diendapkan dari larutan pada bukaan-bukaan batuan(101; 102), yang zirconia berupa Fissure-vein, Shear-zone deposits, Stockworks, Ladder-vein, Saddle-reefs, Tension crack filling, Brecia filling (vulkanik, tektonik dancollapse),Solution cavity filling (caves dan Channels), Gash-vein, Pore-space filling, Vessiculer fillings(60; 103).

\section{METODE}

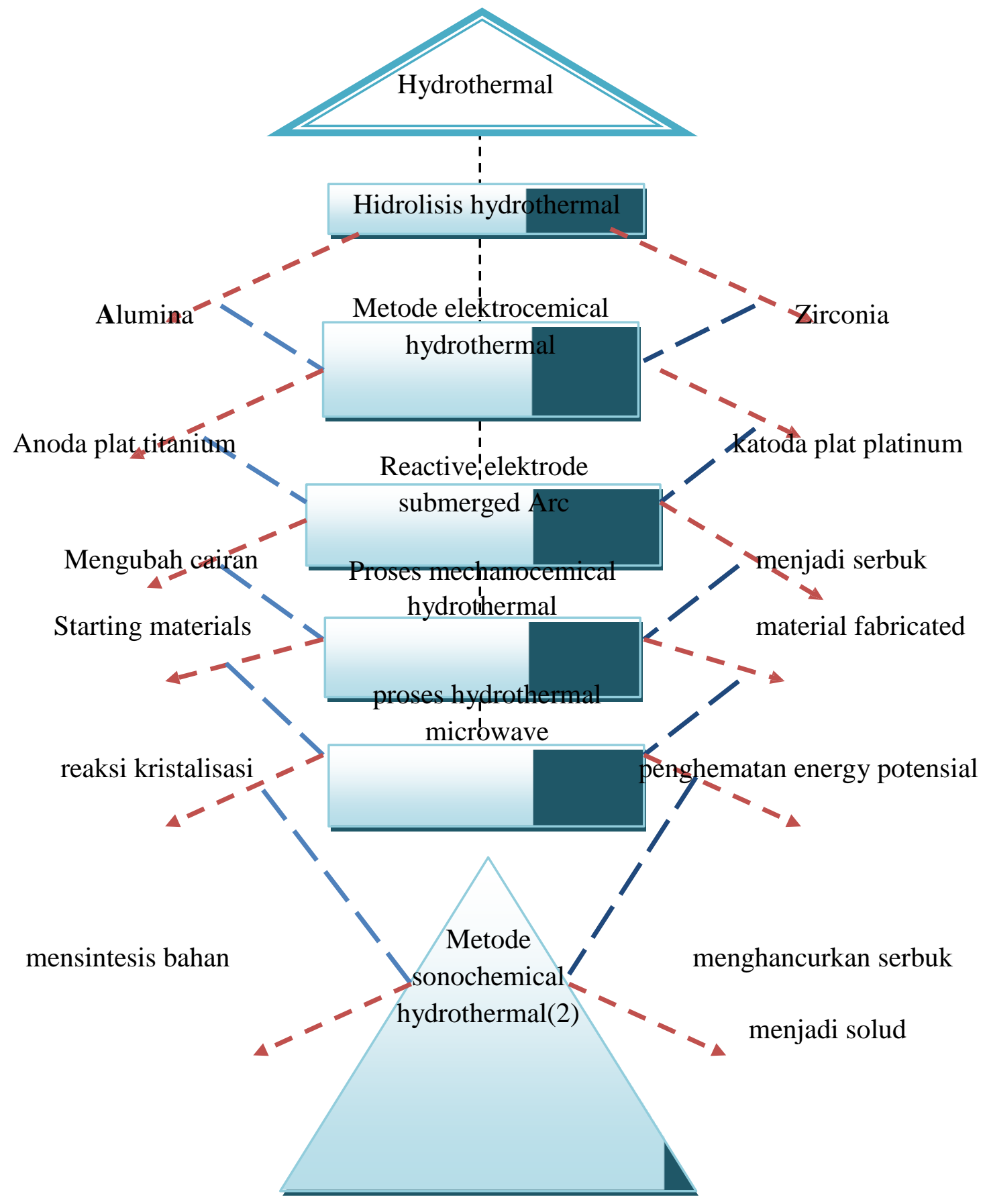



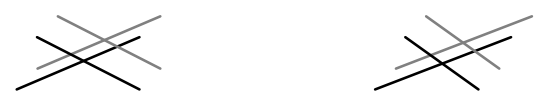

\section{Bagian 1 : Fishbone Metode Hidrotermal}

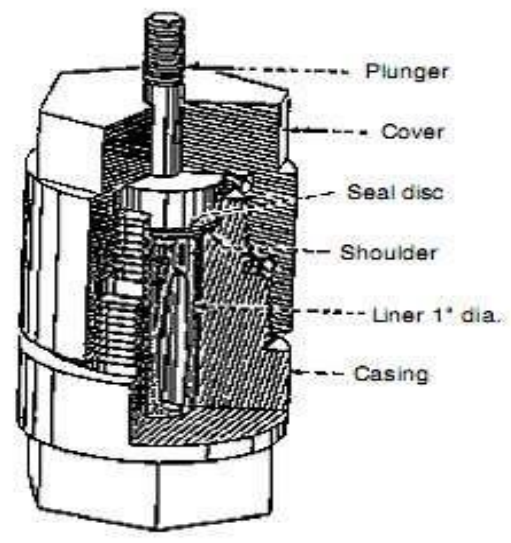

Gambar 1. Autoclave dengan penutup flat plate : ini merupakan alat yang ditemukan oleh Autoclave engineers mereka membuat satu baris lengkap dari katup skala laboratorium , tabung, collars ,mencocokan atas koneksi dsb, serta dapat digunakan untuk proses kimia lain(2)

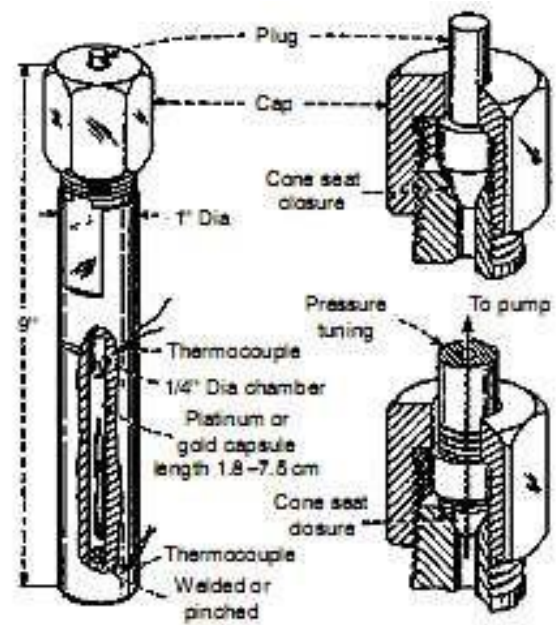

Gambar 2. Reaksi vessel dengan penutup cold-cone seat (Tem-Press).: merupakan sumber terbaik atas penelitian kapal dari segala bentuk ,meliputi tabung penguji bom, dan gas alat penguat atas gas dikhususkan seperti argon,hidrogen,oksigen,amoniak dan sebagainya (2). 


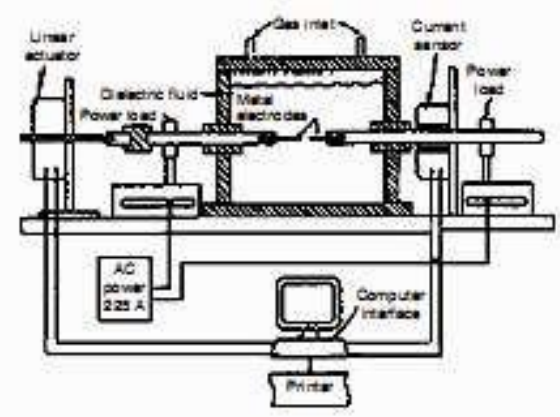

Gambar 3. Schematic of microprocessor-controlled RESA apparatus for fine powder Preparation: merupakan apparatus untuk memproduksi serbuk (2)

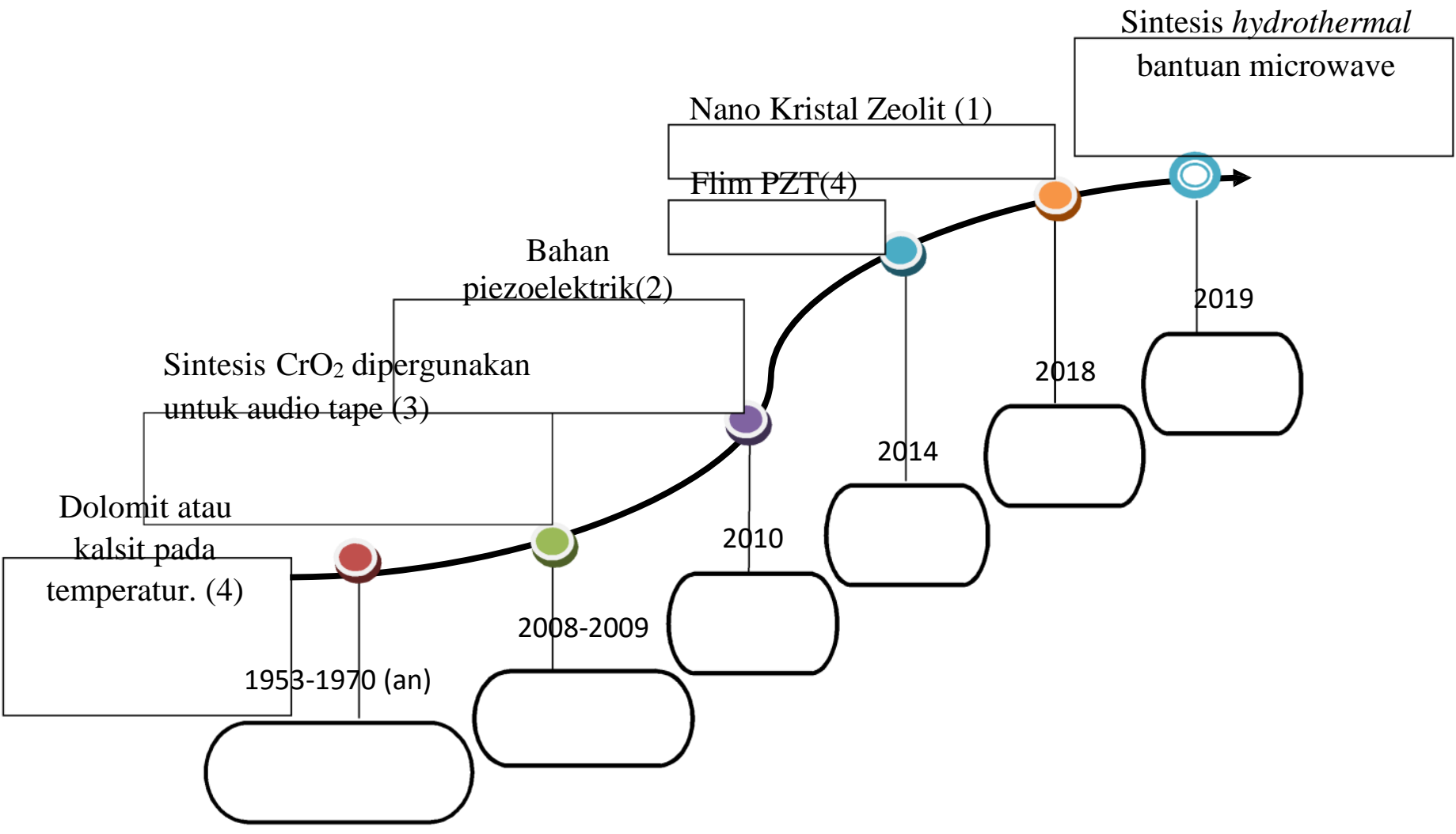

Keterangan :

- = Sintesis Hydrothermal terhadap Dolomit atau Kalsit pada temperatur rendah $\left(200-300^{\circ} \mathrm{C}\right) .(4)$

= Sintesis Kronium dioksida $\mathrm{CrO}_{2}$ dipergunakan untuk audio tape. (3)

= Sintesis Hydrothermal Bahan piezoelektrik (Keramik). (2)

= Sintesis Hydrothermal Flim PZT atau $\mathrm{PbTiO}_{3}(4)$ 
= Sintesis Hydrothermal terhadap karakteristik NanoKristal Zeolit dari Abu sekam padi. (1)

$=$ Sintesis Hydrothermal dengan menggunakan bantuan microwave

\section{Bagian 2 : Roadmap Penggunaan Sintesis Hidrotermal}

\section{PEMBAHASAN}

Sintesis hydrothermal termasuk salah satu teknik dari dari pengkristalan dari temperatur tinggi pada aqueous solutions pada tekanan tinggi. Terminologi hydrothermal berasal dari geologi. Para geokemist dan mineralogist telah mempelajari fase kesetimbangan dari hydrothermal sejak abad ini. George W Morey di Carnegie Institut dan kemudian Percy W Bridgman di Universitas Harvard telah berjasa besar meletakkan dasar yang diperlukan untuk dari media reaktif pada temperatur dan tekanan dimana sebagian besar kerja hydrothermal dikonduksikan. Sintesis hydrothermal dapat didefinisikan sebagai metode sintesis dari kristal tunggal yang tergantung pada kesolutan dari mineral pada air panas dibawah tekanan tinggi. Pertumbuhan kristal dibentuk dalam apparatus yang terdiri dari tekanan vessel baja yang disebut autoclave, yang mana nutrient dihasilkan terus bersama air. Gradien suhu ditentukan pada akhir kebalikan dari ruang pertumbuhan.

Prinsip teknik hydrothermal yaitu pemanasan reaktan dalam wadah tertutup dengan menggunakan medium air dimana sistem yang tertutup ini memungkinkan tekanan dan suhu yang meningkat dengan cepat. Sintesis hydrothermal secara umum dapat diartikan sebagai sintesis kristal atau pertumbuhan kristal pada temparatur dan tekanan tinggi. Sintesis hydrothermal dilakukan pada suhu dibawah $300^{\circ} \mathrm{C}$. Sehingga memperoleh hasil kemurnian dan kristalinitas yang tinggi dengan hanya memanfaatkan mineral alam Indonesia yang berkualitas rendah sebagai bahan utama dalam metode hydrothermal.

Kelebihan dari teknik sintesis hydrothermal diantaranya adalah : (1) terbentuk serbuk secara langsung dari larutan, karena sudah dikaltanasi pada suhu tinggi $\left(1100^{\circ} \mathrm{C}\right)$ selama 10 jam sehingga terjadinya serbuk dalam larutan secara langsung, (2) ukuran partikel dan bentuknya dapat dikontrol dengan menggunakan material awal dan kondisi hydrothermal yang berbeda, dan (3) kereaktifan bubuk yang dihasilkan tinggi, ini disebabkan oleh 
penggunaan suhu yang sangat tinggi (4) pada kondisi super-heated water, oksida logam yang tidak larut dalam air dapat menjadi larut. Atau bila temperatur dan tekanan tersebut belum mampu, maka dapat ditambahkan garam alkali atau logam yang anionnnya dapat membentu kompleks dengan padatan sehingga padatan menjadi larut.

Sedangkan kekurangan teknik ini adalah (1) Solubilitas tidak diketahui, sebab kemampuan suatu zat untuk dapat larut dalam suatu pelarut awal harus diketahui untuk mengatur temperatur dan tekanan supaya sampel yang digunakan dapat bercampur secara homogen , (2) slurry hydrothermal bersifat korosif, dan (3) penggunaan bejana tekanan tinggi akan berbahaya jika terjadi kecelakaan (4) Membutuhkan temperatur tinggi (energi tinggi) (5) waktu reaksi sangat panjang., membutuhkan waktu lebih dari 24 jam (6) Produk tidak homogen dalam komposisi,ini disebabkan oleh kemampuan solubilitas awal material tidak diketahui. Dalam dintesis hidrotermal memiliki beberapa metode yaitu reactive elektrode submerged Arc, proses mechanocemical hydrothermal, proses hydrothermal microwave, metode sonochemical hydrothermal. Dan telah terdapat material yang terbentuk dari awal tahun 1953 sampai sekarang, kami memperkirakan pada tahun 2018 keatas sintesis hidrothermal yang digunakan terhadap karakteristik nanokristal Zeolit dari abu sekam padi dapat digunakan untuk menciptakan suatu material yang bermanfaat untuk kebutuhan konsumen.

\section{KESIMPULAN}

Sintesis hydrothermal merupakan suatu teknik pengkristalan dari temperatur tinggi pada keadaan campuran pada tekanan tinggi. Sintesis hydrothermal memiliki beberapa metode yang digunakan dalam proses pembentukan material. Selain itu sintesis hydrothermal memiliki kelebihan seperti,terbentukanya serbuk secara langsung, ukuran partikel dan bentuk partikel dapat dikontrol, kereaktifan serbuk yang dihasilkan tinggi .Dan kekurangan dari sintesis hydrothermal yaitu membutuhkan temperatur yang tinggi dan proses pembuatan material membutuhkan waktu reaksi yang sangat panjang.

\section{SARAN}

Ucapan terimakasih kami sampaikan kepada Bapak Dr Rahadian M.Si yang telah membimbing kami dalam mata kuliah Kimia Material. Semoga review ini berguna dan bermanfaat bagi pembaca. Mohon maaf apabila ada kesalahan dan kekurangan dalam penulisan review ini. 


\section{Referensi}

[1] C. Mercier, J. Lossouarn, C. L. Nesbo, T. H. A. Haverkamp, A. C. Baudoux, M. Jebbar, et al., Feb 2018, "Two viruses, MCV1 and MCV2, which infect Marinitoga bacteria isolated from deep-sea hydrothermal vents: functional and genomic analysis," Environ Microbiol, vol. 20, pp. 577-587.

[2] A.Walujodjati, 2008,"Sintesis Hidrotermal Dari Serbuk Oksida Keramik".

[3] Trisunaryanti, 2006,"Sintesis kromium dioksida" .

[4] R. y. Chicha Nureini, Dwinna Rahmi, 2016,"Sintesis Talk dari batuan dolomit dan kuarsa lokal serta krospeknya untuk industri kimia dan farmasi."

[5] J. Chen, Oct 2018,"Bio-oil production from hydrothermal liquefaction of Pteris vittata L.: Effects of operating temperatures and energy recovery," Bioresour Technol, vol. 265, pp. 320-327.

[6] S. Nuchdang, J. C. Frigon, C. Roy, G. Pilon, C. Phalakornkule, and S. R. Guiot, Jan 2018."Hydrothermal post-treatment of digestate to maximize the methane yield from the anaerobic digestion of microalgae," Waste Manag, vol. 71, pp. 683-688.

[7] S. S. Ma, P. Xu, Z. L. Cai, Q. Li, Z. L. Ye, and Y. M. Zhou, "Template-Assisted Hydrothermal Growth of One-Dimensional Zinc Oxide Nanowires for Photocatalytic Application, Jul 1 2018." J Nanosci Nanotechnol, vol. 18, pp. 5113-5118.

[8] S. Ramaraj, S. Mani, S. M. Chen, S. Palanisamy, V. Velusamy, J. M. Hall, et al., Mar 19 2018."Hydrothermal Synthesis of Cr2Se3 Hexagons for Sensitive and Low-level Detection of 4-Nitrophenol in Water," Sci Rep, vol. 8, p. 4839.

[9] M. Piao, J. Chu, X. Wang, Y. Chi, H. Zhang, C. Li, et al., , Jan 122018 "Hydrothermal synthesis of stable metallic 1T phase WS2 nanosheets for thermoelectric application," Nanotechnology, vol. 29, p. 025705.

[10] W. Wang, Y. Xu, X. Wang, B. Zhang, W. Tian, and J. Zhang, Feb 2018. "Hydrothermal liquefaction of microalgae over transition metal supported $\mathrm{TiO} 2$ catalyst," Bioresour Technol, vol. 250, pp. 474-480, F.

[11] C. Wang, H. Fan, X. Ren, J. Ma, J. Fang, and W. Wang, "Hydrothermally Induced Oxygen Doping of Graphitic Carbon Nitride with a Highly Ordered Architecture and Enhanced Photocatalytic Activity, Feb 22 2018." ChemSusChem, vol. 11, pp. 700708.

[12] A. R. Noviyanti, Ismunandar, B. Prijamboedi, I.N. and Marsih., 2016. "Hydrothermal Preparation of Apatite-Type Phases La9.33Si6O26 and La9M1Si6O26.5 (M= Ca, Sr, Ba). ITB Journal of Science. 44: 193-203,".

[13] Y. Sun, C. Liu, Y. Zan, G. Miao, H. Wang, and L. Kong, Apr 122018 ,Hydrothermal Carbonization of Microalgae (Chlorococcum sp.) for Porous Carbons With High Cr(VI) Adsorption Performance," Appl Biochem Biotechnol.

[14] K. W. Jung, S. Y. Lee, and Y. J. Lee, Jul 2018, "Hydrothermal synthesis of hierarchically structured birnessite-type $\mathrm{MnO} 2 /$ biochar composites for the adsorptive removal of $\mathrm{Cu}$ (II) from aqueous media," Bioresour Technol, vol. 260, pp. 204-212.

[15] G. T. Zhu, X. L. Hu, S. He, X. M. He, S. K. Zhu, and Y. Q. Feng, Aug 242018 "Hydrothermally tailor-made chitosan fiber for micro-solid phase extraction of petroleum acids in crude oils," J Chromatogr A, vol. 1564, pp. 42-50.

[16] X. Ou, S. Lei, X. Zhang, K. Wan, Y. Wang, W. Zhou, et al., Aug 3 2018."Hydrothermal growth of ferrous hydroxide terephthalate as a new positive electrode material for supercapacitors," Dalton Trans.

[17] Y. Han, G. Gonnella, N. Adam, A. Schippers, L. Burkhardt, S. Kurtz, et al., Jul 10 2018,"Hydrothermal chimneys host habitat-specific microbial communities: analogues for studying the possible impact of mining seafloor massive sulfide

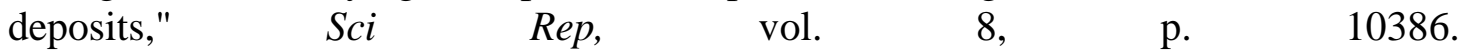


[18] Q. Lang, Y. Guo, Q. Zheng, Z. Liu, and C. Gai, Oct 2018,"Co-hydrothermal carbonization of lignocellulosic biomass and swine manure: Hydrochar properties and heavy metal transformation behavior," Bioresour Technol, vol. 266, pp. 242-248,.

[19] P. Borthakur and M. R. Das, Apr 152018 "Hydrothermal assisted decoration of NiS2 and $\mathrm{CoS}$ nanoparticles on the reduced graphene oxide nanosheets for sunlight driven photocatalytic degradation of azo dye: Effect of background electrolyte and surface charge," J Colloid Interface Sci, vol. 516, pp. 342-354.

[20] P. Zarringhadam and S. Farhadi, Jun 2018,"Hydrothermal Synthesis of Novel Magnetic Plate-Like Bi2O2CO3/CoFe2O4 Hybrid Nanostructures and Their Catalytic Performance for the Reduction of Some Aromatic Nitrocompounds," Acta Chim Slov, vol. 65 , pp. 448-461,

[21] K. Fulle, L. D. Sanjeewa, C. D. McMillen, and J. W. Kolis, May 15 2018, "High temperature hydrothermal synthesis of rare-earth titanates: synthesis and structure of RE5Ti4O15 $(\mathrm{OH})(\mathrm{RE}=\mathrm{La}, \mathrm{Er}), \mathrm{Sm} 3 \mathrm{TiO} 5(\mathrm{OH}) 3, \mathrm{RE} 5 \mathrm{Ti} 2 \mathrm{O} 11(\mathrm{OH})(\mathrm{RE}=\mathrm{Tm}-\mathrm{Lu})$ and Ce2Ti4O11," Dalton Trans, vol. 47, pp. 6754-6762

[22] R. Zainul, 2018, "Thermal and Surface Evaluation on The Process of Forming a $\mathrm{Cu} 2 \mathrm{O} / \mathrm{CuO}$ Semiconductor Photocatalyst on a Thin Copper Plate,".

[23] R. Zhao, Y. Li, X. Li, Y. Li, B. Sun, S. Chao, et al., Mar 15 2018, "Facile hydrothermal synthesis of branched polyethylenimine grafted electrospun polyacrylonitrile fiber membrane as a highly efficient and reusable bilirubin adsorbent in hemoperfusion," J Colloid Interface Sci, vol. 514, pp. 675-685.

[24] S. Sivalingam and S. Sen, Jul 20 2018, "Rapid ultrasound assisted hydrothermal synthesis of highly pure nanozeolite $\mathrm{X}$ from fly ash for efficient treatment of industrial effluent," Chemosphere, vol. 210, pp. 816-823.

[25] G. Gallina, E. R. Alfageme, P. Biasi, and J. Garcia-Serna, Jan 2018. "Hydrothermal extraction of hemicellulose: from lab to pilot scale," Bioresour Technol, vol. 247, pp. 980-991.

[26] X. Gao, Q. Li, and J. Qiu, Apr 2018."Hydrothermal modification and recycling of nonmetallic particles from waste print circuit boards," Waste Manag, vol. 74, pp. 427434.

[27] L. Gremillard, J. Chevalier, L. Martin, T. Douillard, S. Begand, K. Hans, et al. Mar 1 2018, "Sub-surface assessment of hydrothermal ageing in zirconia-containing femoral heads for hip joint applications," Acta Biomater, vol. 68, pp. 286-295,.

[28] R. Zainul, 2018, "Studi literasi menggunakan endnote dan aplikasi pembantu,".

[29] A. Gallifuoco, L. Taglieri, F. Scimia, A. A. Papa, and G. Di Giacomo, Jul 2018."Hydrothermal conversions of waste biomass: Assessment of kinetic models using liquid-phase electrical conductivity measurements," Waste Manag, vol. 77, pp. 586-592.

[30] P. H. Hsieh, C. E. Tsai, B. C. Chang, and K. H. Lii, Jun 18 2018, "High-Temperature, High-Pressure Hydrothermal Synthesis and Characterization of an Acentric Borate Fluoride: Ba2B5O9F.0.5H2O," Inorg Chem, vol. 57, pp. 7239-7243.

[31] X. Hu, P. Xu, H. Gong, and G. Yin, Jan 17 2018, "Synthesis and Characterization of WO(3)/Graphene Nanocomposites for Enhanced Photocatalytic Activities by OneStep In-Situ Hydrothermal Reaction," Materials (Basel), vol. 11.

[32] G. Huang, W. Kang, Q. Geng, B. Xing, Q. Liu, J. Jia, et al., Apr 3 2018, "One-Step Green Hydrothermal Synthesis of Few-Layer Graphene Oxide from Humic Acid," Nanomaterials (Basel), vol. 8.

[33] M. Hui, J. Cheng, and Z. Sha, May 10 2018,"First comprehensive analysis of lysine acetylation in Alvinocaris longirostris from the deep-sea hydrothermal vents," $B M C$ $\begin{array}{lllll}\text { Genomics, } & \text { vol. } & 19, & \text { p. } & 352 .\end{array}$ 
[34] S. E. Humphris and F. Klein, Jan 3 2018, "Progress in Deciphering the Controls on the Geochemistry of Fluids in Seafloor Hydrothermal Systems," Ann Rev Mar Sci, vol. 10, pp. 315-343.

[35] P. T. L. Huong, T. V. Son, V. N. Phan, L. T. Tam, and A. T. Le, Aug 12018 , "Microstructure and Chemo-Physical Characterizations of Functional Graphene Oxide-Iron Oxide-Silver Ternary Nanocomposite Synthesized by One-Pot Hydrothermal Method," J Nanosci Nanotechnol, vol. 18, pp. 5591-5599.

[36] T. T. Huynh, A. Van Nguyen, H. Q. Pham, N. H. Vinh, L. G. Bach, and V. T. Thanh Ho, Oct 1 2018, "One-Step Hydrothermal Synthesis of a New Nanostructure Ti07Ir0(3)O(2) for Enhanced Electrical Conductivity: The Effect of $\mathrm{pH}$ on the Formation of Nanostructure," J Nanosci Nanotechnol, vol. 18, pp. 6928-6933.

[37] H. Hwang, J. H. Lee, I. G. Choi, and J. W. Choi, Jan 29 2018, "Comprehensive characterization of hydrothermal liquefaction products obtained from woody biomass under various alkali catalyst concentrations," Environ Technol, pp. 1-11.

[38] K. Kanie, M. Sakaguchi, F. Muto, M. Horie, M. Nakaya, T. Yokoi, et al., 2018,"Mechanochemically assisted hydrothermal synthesis of Sn-substituted MFItype silicates," Sci Technol Adv Mater, vol. 19, pp. 545-553.

[39] G. V. Kiriukhina, O. V. Yakubovich, E. M. Kochetkova, O. V. Dimitrova, and A. S. Volkov, Aug 1 2018, "A first Mn member in the struvite morphotropic series, $\mathrm{CsMn}(\mathrm{H} 2 \mathrm{O}) 6(\mathrm{PO} 4)$ : hydrothermal synthesis, crystal structure and interconnections within the family of related phosphates," Acta Crystallogr C Struct Chem, vol. 74, pp. 936-943.

[40] I. Koltsov, J. Smalc-Koziorowska, M. Przesniak-Welenc, M. Malysa, G. Kimmel, J. McGlynn, et al., May 172018 "Mechanism of Reduced Sintering Temperature of $\mathrm{Al}(2) \mathrm{O}(3)(-) \mathrm{ZrO}(2)$ Nanocomposites Obtained by Microwave Hydrothermal Synthesis," Materials (Basel), vol. 11,

[41] P. A. Kots, A. V. Zabilska, E. V. Khramov, Y. V. Grigoriev, Y. V. Zubavichus, and Ivanova, II, Sep 11 2018. "Mechanism of $\mathrm{Zr}$ Incorporation in the Course of Hydrothermal Synthesis of Zeolite BEA," Inorg Chem.

[42] Y. K. Kshetri, C. Regmi, H. S. Kim, S. W. Lee, and T. H. Kim, May 18 2018., "Microwave hydrothermal synthesis and upconversion properties of $\mathrm{Yb}(3+) / \operatorname{Er}(3+)$ doped YVO4 nanoparticles," Nanotechnology, vol. 29, p. 204004.

[43] K. Lan, Y. Liu, W. Zhang, Y. Liu, A. Elzatahry, R. Wang, et al., Mar 21 2018,"Uniform Ordered Two-Dimensional Mesoporous TiO2 Nanosheets from Hydrothermal-Induced Solvent-Confined Monomicelle Assembly," J Am Chem Soc, vol. 140, pp. 4135-4143.

[44] S. Inaba, Mar 2018,"Primary Formation Path of Formaldehyde in Hydrothermal Vents," Orig Life Evol Biosph, vol. 48, pp. 1-22,

[45] S. Ji, C. Miao, H. Liu, L. Feng, X. Yang, and H. Guo, Jun 13 2018, "A Hydrothermal Synthesis of Fe3O4@C Hybrid Nanoparticle and Magnetic Adsorptive Performance to Remove Heavy Metal Ions in Aqueous Solution," Nanoscale Res Lett, vol. 13, p. 178.

[46] Y. Jiao, C. Wan, W. Bao, H. Gao, D. Liang, and J. Li, "Facile hydrothermal synthesis of Fe3O4@cellulose aerogel nanocomposite and its application in Fenton-like degradation of Rhodamine B," Carbohydr Polym, vol. 189, pp. 371-378, Jun 12018.

[47] Q. W. Jin, Y. H. Hu, and L. Sun, Feb 2018, "Alteromonas oceani sp. nov., isolated from deep-sea sediment of a hydrothermal field," Int J Syst Evol Microbiol, vol. 68, pp.

657-662. 
[48] Q. W. Jin, Q. L. Sun, J. Zhang, and L. Sun, Sep 2018, "First characterization of two C-type lectins of the tubeworm Alaysia sp. from a deep-sea hydrothermal vent," Dev Comp Immunol, vol. 86, pp. 17-25.

[49] M. A. Jorquera, S. Gabler, N. G. Inostroza, J. J. Acuna, M. A. Campos, D. MenezesBlackburn, et al., Feb 2018, "Screening and Characterization of Phytases from Bacteria Isolated from Chilean Hydrothermal Environments," Microb Ecol, vol. 75, pp. 387-399.

[50] K. W. Jung, S. Y. Lee, and Y. J. Lee, Aug 2018 ,"Facile one-pot hydrothermal synthesis of cubic spinel-type manganese ferrite/biochar composites for environmental remediation of heavy metals from aqueous solutions," Bioresour Technol, vol. 261, pp. 1-9.

[51] W. Lekphet, S. Y. Ho, C. Su, P. Sireesha, S. Kathirvel, Y. F. Lin, et al., Feb 1 2018,"Effect of Ammonium Salts on the Hydrothermal Synthesis of $\mathrm{TiO}(2)$ Nanocubes for Dye-Sensitized Solar Cells," J Nanosci Nanotechnol, vol. 18, pp. 967975.

[52] E. Lemmens, N. De Brier, K. M. Spiers, C. Ryan, J. Garrevoet, G. Falkenberg, et al., Oct 30 2018,"The impact of steeping, germination and hydrothermal processing of wheat (Triticum aestivum L.) grains on phytate hydrolysis and the distribution, speciation and bio-accessibility of iron and zinc elements," Food Chem, vol. 264, pp. 367-376.

[53] M. Liu, Y. Duan, K. Bikane, and L. Zhao, 2018, "The Migration and Transformation of Heavy Metals in Sewage Sludge during Hydrothermal Carbonization Combined with Combustion," Biomed Res Int, vol. 2018, p. 1913848.

[54] Q. Ma, L. Han, and G. Huang, Aug 21 2018, "Effect of water-washing of wheat straw and hydrothermal temperature on its hydrochar evolution and combustion properties," Bioresour Technol, vol. 269, pp. 96-103.

[55] J. Machon, P. Lucas, J. Ravaux, and M. Zbinden, Aug 24 2018, "Comparison of Chemoreceptive Abilities of the Hydrothermal Shrimp Mirocaris fortunata and the Coastal Shrimp Palaemon elegans," Chem Senses, vol. 43, pp. 489-501.

[56] A. Maghsodi, L. Adlnasab, M. Shabanian, and M. Javanbakht, Nov 2018 ,"Optimization of effective parameters in the synthesis of nanopore anodic aluminum oxide membrane and arsenic removal by prepared magnetic iron oxide nanoparicles in anodic aluminum oxide membrane via ultrasonic-hydrothermal method," Ultrason Sonochem, vol. 48, pp. 441-452.

[57] H. Mao, X. Chen, R. Huang, M. Chen, R. Yang, P. Lan, et al., Jun 22 2018,"Fast preparation of carbon spheres from enzymatic hydrolysis lignin: Effects of hydrothermal carbonization conditions," Sci Rep, vol. 8, p. 9501.

[58] A. S. Matharu, E. M. de Melo, J. Remon, S. Wang, A. Abdulina, and E. Kontturi, Apr 25 2018,"Processing of Citrus Nanostructured Cellulose: A Rigorous Design-ofExperiment Study of the Hydrothermal Microwave-Assisted Selective Scissoring Process," ChemSusChem, vol. 11, pp. 1344-1353.

[59] K. McGaughy and M. T. Reza, Feb 28 2018. "Recovery of Macro and MicroNutrients by Hydrothermal Carbonization of Septage," J Agric Food Chem, vol. 66, pp. 1854-1862.

[60] S. Nath, A. Biswas, P. P. Kour, L. S. Sarma, U. K. Sur, and B. G. Ankamwar, Aug 1 2018,"Synthesis of Mesoporous Nanocrystalline Zirconia by Surfactant-Assisted Hydrothermal Approach," J Nanosci Nanotechnol, vol. 18, pp. 5390-5396.

[61] Y. Nie and X. Bi, 2018, "Life-cycle assessment of transportation biofuels from hydrothermal liquefaction of forest residues in British Columbia," Biotechnol Biofuels, vol. 11 , p. 
[62] S. Nizamuddin, M. T. H. Siddiqui, H. A. Baloch, N. M. Mubarak, G. Griffin, S. Madapusi, et al., Jun 2018., "Upgradation of chemical, fuel, thermal, and structural properties of rice husk through microwave-assisted hydrothermal carbonization," Environ Sci Pollut Res Int, vol. 25, pp. 17529-17539.

[63] T. Ogino, S. Maegawa, S. Shigeno, K. Fujikura, and H. Toyohara, 2018, "Highly sensitive avoidance plays a key role in sensory adaptation to deep-sea hydrothermal vent environments," PLoS One, vol. 13, p. e0189902

[64] M. A. Ojo, , Jun 2018, "Changes in Some Antinutritional Components and In Vitro Multienzymes Protein Digestibility during Hydrothermal Processing of Cassia hirsutta," Prev Nutr Food Sci, vol. 23, pp. 152-159.

[65] B. M. Omar, M. Bita, I. Louafi, and A. Djouadi, 2018, "Esterification process catalyzed by ZSM-5 zeolite synthesized via modified hydrothermal method," MethodsX, vol. 5, pp. 277-282.

[66] K. A. Pace, V. Kocevski, S. G. Karakalos, G. Morrison, T. Besmann, and H. C. Zur Loye, Apr 16 2018, "Na2(UO2)(BO3): An All-Uranium(V) Borate Synthesized under Mild Hydrothermal Conditions," Inorg Chem, vol. 57, pp. 4244-4247.

[67] K. Y. Park, K. Lee, and D. Kim, Jun 2018, "Characterized hydrochar of algal biomass for producing solid fuel through hydrothermal carbonization," Bioresour Technol, vol. 258, pp. 119-124.

[68] C. C. Peng, H. K. Liu, and K. H. Lii, Feb 5 2018, "High-Temperature, High-Pressure Hydrothermal Synthesis, Crystal Structure, Thermal Stability, and Solid State NMR Spectroscopy of an Aluminum Borate, Ba[AlB4O8(OH)]," Inorg Chem, vol. 57, pp. $1545-1549$.

[69] A. Perez, G. Blazquez, I. Ianez-Rodriguez, O. Osegueda, and M. Calero, Jul 29 2018.,"Optimization of the sugar hydrothermal extraction process from olive cake using neuro-fuzzy models," Bioresour Technol, vol. 268, pp. 81-90.

[70] M. Piecyk, B. Druzynska, A. Oltarzewska, R. Wolosiak, E. Worobiej, and E. Ostrowska-Ligeza, Oct 15 2018, "Effect of hydrothermal modifications on properties and digestibility of grass pea starch," Int J Biol Macromol, vol. 118, pp. 2113-2120.

[71] G. Pillot, E. Frouin, E. Pasero, A. Godfroy, Y. Combet-Blanc, S. Davidson, et al., Jul 2018."Specific enrichment of hyperthermophilic electroactive Archaea from deep-sea hydrothermal vent on electrically conductive support," Bioresour Technol, vol. 259, pp. 304-311.

[72] P. Pramanik, B. Chakrabarti, A. Bhatia, S. D. Singh, A. Maity, P. Aggarwal, et al., Mar 14 2018,"Effect of elevated temperature on soil hydrothermal regimes and growth of wheat crop," Environ Monit Assess, vol. 190, p. 217.

[73] F. Qian, X. Zhu, Y. Liu, Q. Shi, L. Wu, S. Zhang, et al., Feb 20 2018. "Influences of Temperature and Metal on Subcritical Hydrothermal Liquefaction of Hyperaccumulator: Implications for the Recycling of Hazardous Hyperaccumulators," Environ Sci Technol, vol. 52, pp. 2225-2234.

[74] P. Ranganathan and S. Savithri, Jun 2018, "Computational Fluid Dynamics simulation of hydrothermal liquefaction of microalgae in a continuous plug-flow reactor," Bioresour Technol, vol. 258, pp. 151-157.

[75] U. Rao, R. Posmanik, L. E. Hatch, J. W. Tester, S. L. Walker, K. C. Barsanti, et al., Nov 2018,"Coupling hydrothermal liquefaction and membrane distillation to treat anaerobic digestate from food and dairy farm waste," Bioresour Technol, vol. 267, pp. 408-415.

[76] L. Reith, K. Lienau, D. S. Cook, R. More, R. I. Walton, and G. R. Patzke, May 23 2018."Monitoring the Hydrothermal Growth of Cobalt Spinel Water Oxidation Catalysts: From Preparative History to Catalytic Activity," Chemistry. 
[77] P. Salinas-de-Leon, B. Phillips, D. Ebert, M. Shivji, F. Cerutti-Pereyra, C. Ruck, et al., Feb 8 2018, "Deep-sea hydrothermal vents as natural egg-case incubators at the Galapagos Rift," Sci Rep, vol. 8, p. 1788.

[78] N. U. Saqib, S. Baroutian, and A. K. Sarmah, Oct 2018, "Physicochemical, structural and combustion characterization of food waste hydrochar obtained by hydrothermal carbonization," Bioresour Technol, vol. 266, pp. 357-363.

[79] D. Scholz, O. Krocher, and F. Vogel, Jul 11 2018, "Deactivation and Regeneration of Sulfonated Carbon Catalysts in Hydrothermal Reaction Environments," ChemSusChem, vol. 11, pp. 2189-2201.

[80] A. Schouw, F. Vulcano, I. Roalkvam, W. P. Hocking, E. Reeves, R. Stokke, et al., Jul 4 2018,"Genome Analysis of Vallitalea guaymasensis Strain L81 Isolated from a Deep-Sea Hydrothermal Vent System," Microorganisms, vol. 6.

[81] R. Shakya, S. Adhikari, R. Mahadevan, E. B. Hassan, and T. A. Dempster, Mar 2018, "Catalytic upgrading of bio-oil produced from hydrothermal liquefaction of Nannochloropsis sp," Bioresour Technol, vol. 252, pp. 28-36.

[82] B. Si, J. Li, Z. Zhu, M. Shen, J. Lu, N. Duan, et al., Jul 15 2018, "Inhibitors degradation and microbial response during continuous anaerobic conversion of hydrothermal liquefaction wastewater," Sci Total Environ, vol. 630, pp. 1124-1132.

[83] J. E. Storesund, A. Lanzen, A. Garcia-Moyano, A. L. Reysenbach, and L. Ovreas, Jun 2018,"Diversity patterns and isolation of Planctomycetes associated with metalliferous deposits from hydrothermal vent fields along the Valu Fa Ridge (SW Pacific)," Antonie Van Leeuwenhoek, vol. 111, pp. 841-858.

[84] J. Tan and X. Jin, Dec 1 2018, "Monodisperse, colloidal and luminescent calcium fluoride nanoparticles via a citrate-assisted hydrothermal route," J Colloid Interface Sci, vol. 531, pp. 444-450..

[85] K. Tang, Y. Zhang, D. Lin, Y. Han, C. A. Chen, D. Wang, et al., 2018, "CultivationIndependent and Cultivation-Dependent Analysis of Microbes in the Shallow-Sea Hydrothermal System Off Kueishantao Island, Taiwan: Unmasking Heterotrophic Bacterial Diversity and Functional Capacity," Front Microbiol, vol. 9, p. 279.

[86] J. L. Urrea, M. Garcia, S. Collado, P. Oulego, and M. Diaz, Jan 15 2018, "Sludge hydrothermal treatments. Oxidising atmosphere effects on biopolymers and physical properties," J Environ Manage, vol. 206, pp. 284-290.

[87] T. Van Cleve, D. Underhill, M. Veiga Rodrigues, C. Sievers, and J. W. Medlin, Mar 27 2018,"Enhanced Hydrothermal Stability of gamma-A12O3 Catalyst Supports with Alkyl Phosphonate Coatings," Langmuir, vol. 34, pp. 3619-3625.

[88] V. Vasudevan, S. Thangavel, G. Nallamuthu, K. Kirubakaran, P. A. Ramasubramanian, and G. Venugopal, May 1 2018, "Enhanced Photocatalytic Properties of Nanostructured WO(3) Semiconductor-Photocatalyst Prepared via Hydrothermal Method," J Nanosci Nanotechnol, vol. 18, pp. 3320-3328.

[89] M. S. Vlaskin, A. V. Grigorenko, Y. I. Kostyukevich, E. N. Nikolaev, G. N. Vladimirov, N. I. Chernova, et al., Jan 1 2018, "Influence of solvent on the yield and chemical composition of liquid products of hydrothermal liquefaction of Arthrospira platensis as revealed by Fourier transform ion cyclotron resonance mass spectrometry," Eur J Mass Spectrom (Chichester), p. 1469066718771209.

[90] G. Wang, Q. Guo, D. Chen, Z. Liu, X. Zheng, A. Xu, et al., Feb 14 2018, "Facile and Highly Effective Synthesis of Controllable Lattice Sulfur-Doped Graphene Quantum Dots via Hydrothermal Treatment of Durian," ACS Appl Mater Interfaces, vol. 10, pp. 5750-5759. 
[91] F. Westall, K. Hickman-Lewis, N. Hinman, P. Gautret, K. A. Campbell, J. G. Breheret, et al., , Mar 2018. "A Hydrothermal-Sedimentary Context for the Origin of Life," Astrobiology, vol. 18, pp. 259-293.

[92] J. Wu, S. R. A. Collins, A. Elliston, N. Wellner, J. Dicks, I. N. Roberts, et al., 2018 ,"Release of cell wall phenolic esters during hydrothermal pretreatment of rice husk and rice straw," Biotechnol Biofuels, vol. 11, p. 162.

[93] S. Wu, G. Fu, W. Lv, J. Wei, W. Chen, H. Yi, et al., Feb 2018, "A Single-Step Hydrothermal Route to 3D Hierarchical $\mathrm{Cu} 2 \mathrm{O} / \mathrm{CuO} / \mathrm{rGO}$ Nanosheets as HighPerformance Anode of Lithium-Ion Batteries," Small, vol. 14.

[94] X. Xu, R. Tu, Y. Sun, Z. Li, and E. Jiang , Aug 2018, "Influence of biomass pretreatment on upgrading of bio-oil: Comparison of dry and hydrothermal torrefaction," Bioresour Technol, vol. 262, pp. 261-270.

[95] B. R. Yadav and A. Garg, Jan 2018. "Hetero-catalytic hydrothermal oxidation of simulated pulping effluent: Effect of operating parameters and catalyst stability," Chemosphere, vol. 191, pp. 128-135.

[96] X. Yang, L. Wu, Y. Xu, C. Ke, F. Hu, X. Xiao, et al., Mar 5 2018, "Identification and characterization of a novel alkalistable and salt-tolerant esterase from the deep-sea hydrothermal vent of the East Pacific Rise," Microbiologyopen.

[97] Y. Zhai, T. Wang, Y. Zhu, C. Peng, B. Wang, X. Li, et al., Jul 2018."Production of fuel pellets via hydrothermal carbonization of food waste using molasses as a binder," Waste Manag, vol. 77, pp. 185-194.

[98] Y. Yuan, X. Xu, C. Jing, P. Zou, C. Zhang, and Y. Li, Feb 1 2018, "Microwave assisted hydrothermal extraction of polysaccharides from Ulva prolifera: Functional properties and bioactivities," Carbohydr Polym, vol. 181, pp. 902-910.

[99] Z. Zhu, L. Rosendahl, S. S. Toor, and G. Chen, Jul 15 2018, "Optimizing the conditions for hydrothermal liquefaction of barley straw for bio-crude oil production using response surface methodology," Sci Total Environ, vol. 630, pp. 560-569.

[100] A. Zykwinska, L. T. Berre, C. Sinquin, D. Ropartz, H. Rogniaux, S. Colliec-Jouault, et al., May 15 2018, "Enzymatic depolymerization of the GY785 exopolysaccharide produced by the deep-sea hydrothermal bacterium Alteromonas infernus: Structural study and enzyme activity assessment," Carbohydr Polym, vol. 188, pp. 101-107.

[101] X. Zhuang, H. Zhan, Y. Huang, Y. Song, X. Yin, and C. Wu, Nov 2018. "Conversion of industrial biowastes to clean solid fuels via hydrothermal carbonization (HTC): Upgrading mechanism in relation to coalification process and combustion behavior," Bioresour Technol, vol. 267, pp. 17-29.

[102] M. H. Moller, C. Glombitza, M. A. Lever, L. Deng, Y. Morono, F. Inagaki, et al., 2018,"D:L-Amino Acid Modeling Reveals Fast Microbial Turnover of Days to Months in the Subsurface Hydrothermal Sediment of Guaymas Basin," Front Microbiol, vol. 9, p. 967.

[103] K. Suzuki, K. Yoshida, H. Watanabe, and H. Yamamoto, Jun 19 2018, "Mapping the resilience of chemosynthetic communities in hydrothermal vent fields," Sci Rep, vol. 8, p. 9364.

[104] A. A. Rahadian Zainul, Hermansyah Aziz, Syukri Arief, Syukri, Edison Munaf, 2015,"Design of Photovoltaic Cell with Copper Oxide Electrode by using Indoor Lights,".

[105] R. Z. Suci Rahma Yani, 2018, "Aktivasi Tanah Napa dan Pengaruhnya Terhadap Adsorpsi Ion Timbal (II)/Pb2+,"

[106] B. O. Rahadian Zainul, Indang Dewata, 2018, "Studi Dinamika Molekular dan Kinetika Reaksi pada Pembelahan Molekul Air untuk Produksi Gas Hidrogen," 
[107] I. D. Rahadian Zainul, 2018, "Determination of pH-BOD-COD and degradation in batang arau watersheds at Padang city,"

[108] A. A. Rahadian Zainul, Hermansyah Aziz, Syukri Arief, Syukri, Edison Munaf, 2018,"Determination of the half-life and the quantum yield of $\mathrm{ZnO}$ semiconductor photocatalyst in humic acid,"

[109] A. A. Rahadian Zainul, Hermansyah Aziz, Syukri Arief, Syukri, Edison Munaf, 2018,"Design and Modification of Copper Oxide Electrodes for Improving Conversion Coefficient Indoors Lights (PV-Cell) Photocells,"

[110] R. Zainul, 2018,"Effect of Temperature and Particle Motion against the ability of ZnO Semiconductor Photocatalyst in Humic Acid,"

[111] A. A. Rahadian Zainul, Hermansyah Aziz, Syukri Arief, Syukri, Edison Munaf, 2018"Photoelectrosplitting Water Mechanism at Carbon Electrode Surface using Indoor lights,"

[112] R. Z. Harry Sanjaya, 2018, "[PDF] dari osf.ioSynthesis and Electrical Properties of ZnO-ITO and Al-ITO thin Film by Spin Coating Technique Through Sol Gel Process,"

[113] R. S. Azwir Anhar, Rahadian Zainul, 2018, "[PDF] dari osf.ioMeasurement of Glycemic Index of West Sumatera Local Rice Genotypes for Healthy Food Selection,"

[114] Mercier C, Lossouarn J, Nesbo CL, Haverkamp THA, Baudoux AC, et al. 2018. Two viruses, MCV1 and MCV2, which infect Marinitoga bacteria isolated from deep-sea hydrothermal vents: functional and genomic analysis. Environmental microbiology 20:577-87

[115]. A.Walujodjati. 2008. Sintesis Hidrotermal Dari Serbuk Oksida Keramik.

[116] Trisunaryanti. 2006. Sintesis kromium dioksida.

[117] Chicha Nureini Ry, Dwinna Rahmi. 2016. Sintesis Talk dari batuan dolomit dan kuarsa lokal serta krospeknya untuk industri kimia dan farmasi.

[118]. Chen J. 2018. Bio-oil production from hydrothermal liquefaction of Pteris vittata L.: Effects of operating temperatures and energy recovery. Bioresource technology 265:320-7

[119] Nuchdang S, Frigon JC, Roy C, Pilon G, Phalakornkule C, Guiot SR. 2018. Hydrothermal post-treatment of digestate to maximize the methane yield from the anaerobic digestion of microalgae. Waste management 71:683-8

[120] Ma SS, Xu P, Cai ZL, Li Q, Ye ZL, Zhou YM. 2018. Template-Assisted Hydrothermal Growth of One-Dimensional Zinc Oxide Nanowires for Photocatalytic Application. Journal of nanoscience and nanotechnology 18:5113-8

[121] Ramaraj S, Mani S, Chen SM, Palanisamy S, Velusamy V, et al. 2018. Hydrothermal Synthesis of Cr2Se3 Hexagons for Sensitive and Low-level Detection of 4-Nitrophenol in Water. Scientific reports 8:4839

[122] Piao M, Chu J, Wang X, Chi Y, Zhang H, et al. 2018. Hydrothermal synthesis of stable metallic 1T phase WS2 nanosheets for thermoelectric application. Nanotechnology 29:025705

[123] Wang W, Xu Y, Wang X, Zhang B, Tian W, Zhang J. 2018. Hydrothermal liquefaction of microalgae over transition metal supported TiO2 catalyst. Bioresource technology 250:474-80

[124]. Wang C, Fan H, Ren X, Ma J, Fang J, Wang W. 2018. Hydrothermally Induced Oxygen Doping of Graphitic Carbon Nitride with a Highly Ordered Architecture and Enhanced Photocatalytic Activity. ChemSusChem 11:700-8 
[125]. Noviyanti AR, Ismunandar, B. Prijamboedi, I.N. , Marsih. 2016. Hydrothermal Preparation

of Apatite-Type Phases La9.33Si6O26 and La9M1Si6O26.5 ( $\mathrm{M}=\mathrm{Ca}, \mathrm{Sr}, \mathrm{Ba}$ ). ITB Journal of Science. 44: 193-203.

[126]. Sun Y, Liu C, Zan Y, Miao G, Wang H, Kong L. 2018. Hydrothermal Carbonization of Microalgae (Chlorococcum sp.) for Porous Carbons With High $\mathrm{Cr}(\mathrm{VI})$ Adsorption Performance. Applied biochemistry and biotechnology

[127]. Jung KW, Lee SY, Lee YJ. 2018. Hydrothermal synthesis of hierarchically structured birnessite-type $\mathrm{MnO} 2 /$ biochar composites for the adsorptive removal of $\mathrm{Cu}(\mathrm{II})$ from aqueous media. Bioresource technology 260:204-12

[128]. Zhu GT, Hu XL, He S, He XM, Zhu SK, Feng YQ. 2018. Hydrothermally tailor-made chitosan fiber for micro-solid phase extraction of petroleum acids in crude oils. Journal of chromatography. A 1564:42-50

[129]. Ou X, Lei S, Zhang X, Wan K, Wang Y, et al. 2018. Hydrothermal growth of ferrous hydroxide terephthalate as a new positive electrode material for supercapacitors. Dalton transactions

[130]. Han Y, Gonnella G, Adam N, Schippers A, Burkhardt L, et al. 2018. Hydrothermal chimneys host habitat-specific microbial communities: analogues for studying the possible impact of mining seafloor massive sulfide deposits. Scientific reports 8:10386

[131]. Lang Q, Guo Y, Zheng Q, Liu Z, Gai C. 2018. Co-hydrothermal carbonization of lignocellulosic biomass and swine manure: Hydrochar properties and heavy metal transformation behavior. Bioresource technology 266:242-8

[132]. Borthakur P, Das MR. 2018. Hydrothermal assisted decoration of NiS2 and CoS nanoparticles on the reduced graphene oxide nanosheets for sunlight driven photocatalytic degradation of azo dye: Effect of background electrolyte and surface charge. Journal of colloid and interface science 516:342-54

[133]. Zarringhadam P, Farhadi S. 2018. Hydrothermal Synthesis of Novel Magnetic PlateLike Bi2O2CO3/CoFe2O4 Hybrid Nanostructures and Their Catalytic Performance for the Reduction of Some Aromatic Nitrocompounds. Acta chimica Slovenica 65:448-61

[134]. Fulle K, Sanjeewa LD, McMillen CD, Kolis JW. 2018. High temperature hydrothermal synthesis of rare-earth titanates: synthesis and structure of RE5Ti4O15(OH) (RE = La, Er), Sm3TiO5 $(\mathrm{OH}) 3, \mathrm{RE} 5 \mathrm{Ti2O} 11(\mathrm{OH}) \quad(\mathrm{RE}=\mathrm{Tm}-\mathrm{Lu})$ and Ce2Ti4O11. Dalton transactions 47:6754-62

[135]. Zainul R. 2018. Thermal and Surface Evaluation on The Process of Forming a Cu2O/CuO Semiconductor Photocatalyst on a Thin Copper Plate.

[136]. Zhao R, Li Y, Li X, Li Y, Sun B, et al. 2018. Facile hydrothermal synthesis of branched polyethylenimine grafted electrospun polyacrylonitrile fiber membrane as a highly efficient and reusable bilirubin adsorbent in hemoperfusion. Journal of colloid and interface science 514:675-85

[137]. Sivalingam S, Sen S. 2018. Rapid ultrasound assisted hydrothermal synthesis of highly pure nanozeolite $X$ from fly ash for efficient treatment of industrial effluent. Chemosphere 210:816-23

[138]. Gallina G, Alfageme ER, Biasi P, Garcia-Serna J. 2018. Hydrothermal extraction of hemicellulose: from lab to pilot scale. Bioresource technology 247:980-91 
[139]. Gao X, Li Q, Qiu J. 2018. Hydrothermal modification and recycling of nonmetallic particles from waste print circuit boards. Waste management 74:427-34

[140]. Gremillard L, Chevalier J, Martin L, Douillard T, Begand S, et al. 2018. Sub-surface assessment of hydrothermal ageing in zirconia-containing femoral heads for hip joint applications. Acta biomaterialia 68:286-95

[141]. Zainul R. 2018. Studi literasi menggunakan endnote dan aplikasi pembantu.

[142]. Gallifuoco A, Taglieri L, Scimia F, Papa AA, Di Giacomo G. 2018. Hydrothermal conversions of waste biomass: Assessment of kinetic models using liquid-phase electrical conductivity measurements. Waste management 77:586-92

[143]. Hsieh PH, Tsai CE, Chang BC, Lii KH. 2018. High-Temperature, High-Pressure Hydrothermal Synthesis and Characterization of an Acentric Borate Fluoride: Ba2B5O9F.0.5H2O. Inorganic chemistry 57:7239-43

[144]. Hu X, Xu P, Gong H, Yin G. 2018. Synthesis and Characterization of WO(3)/Graphene Nanocomposites for Enhanced Photocatalytic Activities by One-Step In-Situ Hydrothermal Reaction. Materials 11

[145]. Huang G, Kang W, Geng Q, Xing B, Liu Q, et al. 2018. One-Step Green Hydrothermal Synthesis of Few-Layer Graphene Oxide from Humic Acid. Nanomaterials 8

[146]. Hui M, Cheng J, Sha Z. 2018. First comprehensive analysis of lysine acetylation in Alvinocaris longirostris from the deep-sea hydrothermal vents. BMC genomics 19:352

[147]. Humphris SE, Klein F. 2018. Progress in Deciphering the Controls on the Geochemistry of Fluids in Seafloor Hydrothermal Systems. Annual review of marine science 10:315-43

[148]. Huong PTL, Son TV, Phan VN, Tam LT, Le AT. 2018. Microstructure and ChemoPhysical Characterizations of Functional Graphene Oxide-Iron Oxide-Silver Ternary Nanocomposite Synthesized by One-Pot Hydrothermal Method. Journal of nanoscience and nanotechnology 18:5591-9

[149]. Huynh TT, Van Nguyen A, Pham HQ, Vinh NH, Bach LG, Thanh Ho VT. 2018. One-Step Hydrothermal Synthesis of a New Nanostructure Ti07IrO(3)O(2) for Enhanced Electrical Conductivity: The Effect of $\mathrm{pH}$ on the Formation of Nanostructure. Journal of nanoscience and nanotechnology 18:6928-33

[150]. Hwang H, Lee JH, Choi IG, Choi JW. 2018. Comprehensive characterization of hydrothermal liquefaction products obtained from woody biomass under various alkali catalyst concentrations. Environmental technology:1-11

[151]. Kanie K, Sakaguchi M, Muto F, Horie M, Nakaya M, et al. 2018. Mechanochemically assisted hydrothermal synthesis of Sn-substituted MFI-type silicates. Science and technology of advanced materials 19:545-53

[152]. Kiriukhina GV, Yakubovich OV, Kochetkova EM, Dimitrova OV, Volkov AS. 2018. A first $\mathrm{Mn}$ member in the struvite morphotropic series, CsMn(H2O)6(PO4): hydrothermal synthesis, crystal structure and interconnections within the family of related phosphates. Acta crystallographica. Section C, Structural chemistry 74:936-43

[153]. Koltsov I, Smalc-Koziorowska J, Przesniak-Welenc M, Malysa M, Kimmel G, et al. 2018. Mechanism of Reduced Sintering Temperature of $\mathrm{Al}(2) \mathrm{O}(3)(-) \mathrm{ZrO}(2)$ Nanocomposites Obtained by Microwave Hydrothermal Synthesis. Materials 11

[154]. Kots PA, Zabilska AV, Khramov EV, Grigoriev YV, Zubavichus YV, Ivanova, II. 2018. Mechanism of Zr Incorporation in the Course of Hydrothermal Synthesis of Zeolite BEA. Inorganic chemistry 
[155]. Kshetri YK, Regmi C, Kim HS, Lee SW, Kim TH. 2018. Microwave hydrothermal synthesis and upconversion properties of $\mathrm{Yb}(3+) / \operatorname{Er}(3+)$ doped YVO4 nanoparticles. Nanotechnology 29:204004

[156]. Lan K, Liu Y, Zhang W, Liu Y, Elzatahry A, et al. 2018. Uniform Ordered TwoDimensional Mesoporous TiO2 Nanosheets from Hydrothermal-Induced SolventConfined Monomicelle Assembly. Journal of the American Chemical Society 140:4135-43

[157]. Inaba S. 2018. Primary Formation Path of Formaldehyde in Hydrothermal Vents. Origins of life and evolution of the biosphere : the journal of the International Society for the Study of the Origin of Life 48:1-22

[158]. Ji S, Miao C, Liu H, Feng L, Yang X, Guo H. 2018. A Hydrothermal Synthesis of Fe304@C Hybrid Nanoparticle and Magnetic Adsorptive Performance to Remove Heavy Metal lons in Aqueous Solution. Nanoscale research letters 13:178

[159]. Jiao Y, Wan C, Bao W, Gao H, Liang D, Li J. 2018. Facile hydrothermal synthesis of Fe304@cellulose aerogel nanocomposite and its application in Fenton-like degradation of Rhodamine B. Carbohydrate polymers 189:371-8

[160]. Jin QW, Hu YH, Sun L. 2018. Alteromonas oceani sp. nov., isolated from deep-sea sediment of a hydrothermal field. International journal of systematic and evolutionary microbiology 68:657-62

[161]. Jin QW, Sun QL, Zhang J, Sun L. 2018. First characterization of two C-type lectins of the tubeworm Alaysia sp. from a deep-sea hydrothermal vent. Developmental and comparative immunology 86:17-25

[162]. Jorquera MA, Gabler S, Inostroza NG, Acuna JJ, Campos MA, et al. 2018. Screening and Characterization of Phytases from Bacteria Isolated from Chilean Hydrothermal Environments. Microbial ecology 75:387-99

[163]. Jung KW, Lee SY, Lee YJ. 2018. Facile one-pot hydrothermal synthesis of cubic spineltype manganese ferrite/biochar composites for environmental remediation of heavy metals from aqueous solutions. Bioresource technology 261:1-9

[163]. Lekphet W, Ho SY, Su C, Sireesha P, Kathirvel S, et al. 2018. Effect of Ammonium Salts on the Hydrothermal Synthesis of TiO(2) Nanocubes for Dye-Sensitized Solar Cells. Journal of nanoscience and nanotechnology 18:967-75

[164]. Lemmens E, De Brier N, Spiers KM, Ryan C, Garrevoet J, et al. 2018. The impact of steeping, germination and hydrothermal processing of wheat (Triticum aestivum L.) grains on phytate hydrolysis and the distribution, speciation and bio-accessibility of iron and zinc elements. Food chemistry 264:367-76

[165]. Liu M, Duan Y, Bikane K, Zhao L. 2018. The Migration and Transformation of Heavy Metals in Sewage Sludge during Hydrothermal Carbonization Combined with Combustion. BioMed research international 2018:1913848

[166]. Ma Q, Han L, Huang G. 2018. Effect of water-washing of wheat straw and hydrothermal temperature on its hydrochar evolution and combustion properties. Bioresource technology 269:96-103

[167]. Machon J, Lucas P, Ravaux J, Zbinden M. 2018. Comparison of Chemoreceptive Abilities of the Hydrothermal Shrimp Mirocaris fortunata and the Coastal Shrimp Palaemon elegans. Chemical senses 43:489-501

[168]. Maghsodi A, Adlnasab L, Shabanian M, Javanbakht M. 2018. Optimization of effective parameters in the synthesis of nanopore anodic aluminum oxide membrane and arsenic removal by prepared magnetic iron oxide nanoparicles in 
anodic aluminum oxide membrane via ultrasonic-hydrothermal method. Ultrasonics sonochemistry 48:441-52

[169]. Mao H, Chen X, Huang R, Chen M, Yang R, et al. 2018. Fast preparation of carbon spheres from enzymatic hydrolysis lignin: Effects of hydrothermal carbonization conditions. Scientific reports 8:9501

[170]. Matharu AS, de Melo EM, Remon J, Wang S, Abdulina A, Kontturi E. 2018. Processing of Citrus Nanostructured Cellulose: A Rigorous Design-of-Experiment Study of the Hydrothermal Microwave-Assisted Selective Scissoring Process. ChemSusChem 11:1344-53

[171]. McGaughy K, Reza MT. 2018. Recovery of Macro and Micro-Nutrients by Hydrothermal Carbonization of Septage. Journal of agricultural and food chemistry 66:1854-62

[172]. Nath S, Biswas A, Kour PP, Sarma LS, Sur UK, Ankamwar BG. 2018. Synthesis of Mesoporous Nanocrystalline Zirconia by Surfactant-Assisted Hydrothermal Approach. Journal of nanoscience and nanotechnology 18:5390-6

[173]. Nie Y, Bi X. 2018. Life-cycle assessment of transportation biofuels from hydrothermal liquefaction of forest residues in British Columbia. Biotechnology for biofuels 11:23

[174]. Nizamuddin S, Siddiqui MTH, Baloch HA, Mubarak NM, Griffin G, et al. 2018. Upgradation of chemical, fuel, thermal, and structural properties of rice husk through microwave-assisted hydrothermal carbonization. Environmental science and pollution research international 25:17529-39

[175]. Ogino T, Maegawa S, Shigeno S, Fujikura K, Toyohara H. 2018. Highly sensitive avoidance plays a key role in sensory adaptation to deep-sea hydrothermal vent environments. PloS one 13:e0189902

[176]. Ojo MA. 2018. Changes in Some Antinutritional Components and In Vitro Multienzymes Protein Digestibility during Hydrothermal Processing of Cassia hirsutta. Preventive nutrition and food science 23:152-9

[177]. Omar BM, Bita M, Louafi I, Djouadi A. 2018. Esterification process catalyzed by ZSM5 zeolite synthesized via modified hydrothermal method. Methods $X$ 5:277-82

[178]. Pace KA, Kocevski V, Karakalos SG, Morrison G, Besmann T, Zur Loye HC. 2018. $\mathrm{Na2}(\mathrm{UO} 2)(\mathrm{BO} 3)$ : An All-Uranium(V) Borate Synthesized under Mild Hydrothermal Conditions. Inorganic chemistry 57:4244-7

[179]. Park KY, Lee K, Kim D. 2018. Characterized hydrochar of algal biomass for producing solid fuel through hydrothermal carbonization. Bioresource technology 258:119-24

[180]. Peng CC, Liu HK, Lii KH. 2018. High-Temperature, High-Pressure Hydrothermal Synthesis, Crystal Structure, Thermal Stability, and Solid State NMR Spectroscopy of an Aluminum Borate, Ba[AlB4O8(OH)]. Inorganic chemistry 57:1545-9

[181]. Perez A, Blazquez G, lanez-Rodriguez I, Osegueda O, Calero M. 2018. Optimization of the sugar hydrothermal extraction process from olive cake using neuro-fuzzy models. Bioresource technology 268:81-90

[182]. Piecyk M, Druzynska B, Oltarzewska A, Wolosiak R, Worobiej E, Ostrowska-Ligeza E. 2018. Effect of hydrothermal modifications on properties and digestibility of grass pea starch. International journal of biological macromolecules 118:2113-20

[183]. Pillot G, Frouin E, Pasero E, Godfroy A, Combet-Blanc Y, et al. 2018. Specific enrichment of hyperthermophilic electroactive Archaea from deep-sea hydrothermal vent on electrically conductive support. Bioresource technology 259:304-11 
[184]. Pramanik P, Chakrabarti B, Bhatia A, Singh SD, Maity A, et al. 2018. Effect of elevated temperature on soil hydrothermal regimes and growth of wheat crop. Environmental monitoring and assessment 190:217

[185]. Qian F, Zhu X, Liu Y, Shi Q, Wu L, et al. 2018. Influences of Temperature and Metal on Subcritical Hydrothermal Liquefaction of Hyperaccumulator: Implications for the Recycling of Hazardous Hyperaccumulators. Environmental science \& technology 52:2225-34

[186]. Ranganathan P, Savithri S. 2018. Computational Fluid Dynamics simulation of hydrothermal liquefaction of microalgae in a continuous plug-flow reactor. Bioresource technology 258:151-7

[187]. Rao U, Posmanik R, Hatch LE, Tester JW, Walker SL, et al. 2018. Coupling hydrothermal liquefaction and membrane distillation to treat anaerobic digestate from food and dairy farm waste. Bioresource technology 267:408-15

[188]. Reith L, Lienau K, Cook DS, More R, Walton RI, Patzke GR. 2018. Monitoring the Hydrothermal Growth of Cobalt Spinel Water Oxidation Catalysts: From Preparative History to Catalytic Activity. Chemistry

[189]. Salinas-de-Leon P, Phillips B, Ebert D, Shivji M, Cerutti-Pereyra F, et al. 2018. Deepsea hydrothermal vents as natural egg-case incubators at the Galapagos Rift. Scientific reports 8:1788

[190]. Saqib NU, Baroutian S, Sarmah AK. 2018. Physicochemical, structural and combustion characterization of food waste hydrochar obtained by hydrothermal carbonization. Bioresource technology 266:357-63

[191]. Scholz D, Krocher O, Vogel F. 2018. Deactivation and Regeneration of Sulfonated Carbon Catalysts in Hydrothermal Reaction Environments. ChemSusChem 11:2189201

[192]. Schouw A, Vulcano F, Roalkvam I, Hocking WP, Reeves E, et al. 2018. Genome Analysis of Vallitalea guaymasensis Strain L81 Isolated from a Deep-Sea Hydrothermal Vent System. Microorganisms 6

[193] Shakya R, Adhikari S, Mahadevan R, Hassan EB, Dempster TA. 2018. Catalytic upgrading of bio-oil produced from hydrothermal liquefaction of Nannochloropsis sp. Bioresource technology 252:28-36

[194]. Si B, Li J, Zhu Z, Shen M, Lu J, et al. 2018. Inhibitors degradation and microbial response during continuous anaerobic conversion of hydrothermal liquefaction wastewater. The Science of the total environment 630:1124-32

[195]. Storesund JE, Lanzen A, Garcia-Moyano A, Reysenbach AL, Ovreas L. 2018. Diversity patterns and isolation of Planctomycetes associated with metalliferous deposits from hydrothermal vent fields along the Valu Fa Ridge (SW Pacific). Antonie van Leeuwenhoek 111:841-58

[196]. Tan J, Jin X. 2018. Monodisperse, colloidal and luminescent calcium fluoride nanoparticles via a citrate-assisted hydrothermal route. Journal of colloid and interface science 531:444-50

[197]. Tang K, Zhang Y, Lin D, Han Y, Chen CA, et al. 2018. Cultivation-Independent and Cultivation-Dependent Analysis of Microbes in the Shallow-Sea Hydrothermal System Off Kueishantao Island, Taiwan: Unmasking Heterotrophic Bacterial Diversity and Functional Capacity. Frontiers in microbiology 9:279 
[198]. Urrea JL, Garcia M, Collado S, Oulego P, Diaz M. 2018. Sludge hydrothermal treatments. Oxidising atmosphere effects on biopolymers and physical properties. Journal of environmental management 206:284-90

[199]. Van Cleve T, Underhill D, Veiga Rodrigues M, Sievers C, Medlin JW. 2018. Enhanced Hydrothermal Stability of gamma-Al2O3 Catalyst Supports with Alkyl Phosphonate Coatings. Langmuir : the ACS journal of surfaces and colloids 34:3619-25

[200]. Vasudevan V, Thangavel S, Nallamuthu G, Kirubakaran K, Ramasubramanian PA, Venugopal G. 2018. Enhanced Photocatalytic Properties of Nanostructured WO(3) Semiconductor-Photocatalyst Prepared via Hydrothermal Method. Journal of nanoscience and nanotechnology 18:3320-8

[201]. Vlaskin MS, Grigorenko AV, Kostyukevich YI, Nikolaev EN, Vladimirov GN, et al. 2018. Influence of solvent on the yield and chemical composition of liquid products of hydrothermal liquefaction of Arthrospira platensis as revealed by Fourier transform ion cyclotron resonance mass spectrometry. European journal of mass spectrometry:1469066718771209

[202]. Wang G, Guo Q, Chen D, Liu Z, Zheng X, et al. 2018. Facile and Highly Effective Synthesis of Controllable Lattice Sulfur-Doped Graphene Quantum Dots via Hydrothermal Treatment of Durian. ACS applied materials \& interfaces 10:5750-9

[203]. Westall F, Hickman-Lewis K, Hinman N, Gautret P, Campbell KA, et al. 2018. A Hydrothermal-Sedimentary Context for the Origin of Life. Astrobiology 18:259-93

[204]. Wu J, Collins SRA, Elliston A, Wellner N, Dicks J, et al. 2018. Release of cell wall phenolic esters during hydrothermal pretreatment of rice husk and rice straw. Biotechnology for biofuels 11:162

[205]. Wu S, Fu G, Lv W, Wei J, Chen W, et al. 2018. A Single-Step Hydrothermal Route to 3D Hierarchical Cu2 O/CuO/rGO Nanosheets as High-Performance Anode of LithiumIon Batteries. Small 14

[206]. Xu X, Tu R, Sun Y, Li Z, Jiang E. 2018. Influence of biomass pretreatment on upgrading of bio-oil: Comparison of dry and hydrothermal torrefaction. Bioresource technology 262:261-70

[207]. Yadav BR, Garg A. 2018. Hetero-catalytic hydrothermal oxidation of simulated pulping effluent: Effect of operating parameters and catalyst stability. Chemosphere 191:128-35

[208]. Yang X, Wu L, Xu Y, Ke C, Hu F, et al. 2018. Identification and characterization of a novel alkalistable and salt-tolerant esterase from the deep-sea hydrothermal vent of the East Pacific Rise. MicrobiologyOpen

[209]. Zhai Y, Wang T, Zhu Y, Peng C, Wang B, et al. 2018. Production of fuel pellets via hydrothermal carbonization of food waste using molasses as a binder. Waste management 77:185-94

[210]. Yuan Y, Xu X, Jing C, Zou P, Zhang C, Li Y. 2018. Microwave assisted hydrothermal extraction of polysaccharides from Ulva prolifera: Functional properties and bioactivities. Carbohydrate polymers 181:902-10

[211]. Zhu Z, Rosendahl L, Toor SS, Chen G. 2018. Optimizing the conditions for hydrothermal liquefaction of barley straw for bio-crude oil production using response surface methodology. The Science of the total environment 630:560-9

[212]. Zykwinska A, Berre LT, Sinquin C, Ropartz D, Rogniaux H, et al. 2018. Enzymatic depolymerization of the GY785 exopolysaccharide produced by the deep-sea 
hydrothermal bacterium Alteromonas infernus: Structural study and enzyme activity assessment. Carbohydrate polymers 188:101-7

[213]. Zhuang X, Zhan H, Huang Y, Song Y, Yin X, Wu C. 2018. Conversion of industrial biowastes to clean solid fuels via hydrothermal carbonization (HTC): Upgrading mechanism in relation to coalification process and combustion behavior. Bioresource technology 267:17-29

[114]. Moller MH, Glombitza C, Lever MA, Deng L, Morono Y, et al. 2018. D:L-Amino Acid Modeling Reveals Fast Microbial Turnover of Days to Months in the Subsurface Hydrothermal Sediment of Guaymas Basin. Frontiers in microbiology 9:967

[115]. Suzuki K, Yoshida K, Watanabe H, Yamamoto H. 2018. Mapping the resilience of chemosynthetic communities in hydrothermal vent fields. Scientific reports 8:9364

[116] D. N. Rahadian Zainul, Marniati Salim, "Optimization of Spirulina Platensis Culture for Antioxidant Production," 2018.

[117] D. D. M Mawardi, R Zainul, "Characterization of PCC Cement by Addition of Napa Soil from Subdistrict Sarilamak 50 Kota District as Alternative Additional Material for Semen Padang," 2018.

[118] B. O. R Zainul, I Dewata, J Efendi, "Thermal and Surface Evaluation on The Process of Forming a $\mathrm{Cu} 2 \mathrm{O} / \mathrm{CuO}$ Semiconductor Photocatalyst on a Thin Copper Plate," 2018.

[119] A. A. Rahadian Zainul, Hermansyah Aziz, Syukri Arief, Syukri, Edison Munaf, "Disain Geometri Reaktor Fotosel Cahaya Ruang," 2018.

[120] C. C. VK Sharma, Rahadian Zainul, PS Naruka, HP Singh, CS Sharma, "Journal of Chemical and Pharmaceutical Research (ISSN: 0975-7384)." 


\title{
a review
}

\section{Solid Stated : principles and Methode}

\author{
Sari Safitri Febriani ${ }^{1}$, Tika Yolanda ${ }^{2}$, Visca Alisia Arianti ${ }^{2}$, Rahadian \\ Zainul $^{2}$ \\ ${ }^{\mathbf{1}}$ Pendidikan Kimia, FMIPA, Universitas Negeri Padang, Indonesia \\ ${ }^{2}$ Pendidikan Kimia, FMIPA, Universitas Negeri Padang, Indonesia \\ ${ }^{3}$ Pendidikan Kimia, FMIPA, Universitas Negeri Padang, Indonesia \\ ${ }^{4}$ Physical Chemistry Laboratory, FMIPA, Universitas Negeri Padang, Indonesia \\ *E-mail : sarifebriani896@gmail.com, Tikayolanda96@gmail.com, \\ viscaalisia96@gmail.com, rahadianzmsiphd@yahoo.com,
}

\begin{abstract}
Abstrak : Metode keadaan padat (Solid Stated) merupakan suatu cara yang dilakukan dengan mereaksikan padatan dengan padatan lainnya dengan suhu yang tinggi. Metode ini dapat digunakan untuk mensintesis material baik organik maupun anorganik. Sintesis material adalah suatu integrasi beberapa material untuk menghasilkan material baru. Pada metode solid stated terdapat beberapa langkah dalam mensintesis material yaitu penggerusan sampel, kompaksi sampel, kalsinasi sampel, sintering sampel, dan terakhir sampel dikarakterisasi.
\end{abstract}

Keyword: Solid stated, Sintesis Material, Metode.

\section{Pendahuluan}

Semakin berkembangnya zaman, semakin banyak metode yang digunakan dalam mensintesis suatu material. Salah satu metode yang sering digunakan adalah metode solid stated. Metode keadaan padat (Solid Stated) merupakan suatu teknik yang digunakan dalam penyediaan padatan polikristalin. Polikristalin meupakan padatan Kristal disintesis secara langsung dari pereaksipereaksinya yang berwujud padat ${ }^{(49)}$. Teknik ini menggunakan suhu yang tinggi bahkan mencapai $1000^{\circ} \mathrm{C}$ hingga $1500{ }^{\circ} \mathrm{C}$, hal ini dilakukan karena pada kenyataannya padatan tidak akan bereaksi pada suhu kamar, tetapi pada suhu tinggi padatan juga akan mengalami laju reaksi yang tinggi pula.

Sintesis material merupakan suatu integrasi beberapa material untuk menghasilkan material baru ${ }^{(49)}$. Material ini dapat berupa senyawa organik maupun anorganik. Salah satu contoh sintesis material menggunakan metode solid stated adalah sintesis piezoelektrik BNT-BT dengan

menambahkan

$\mathrm{SrTiO}_{3}$. 


\section{Metode}

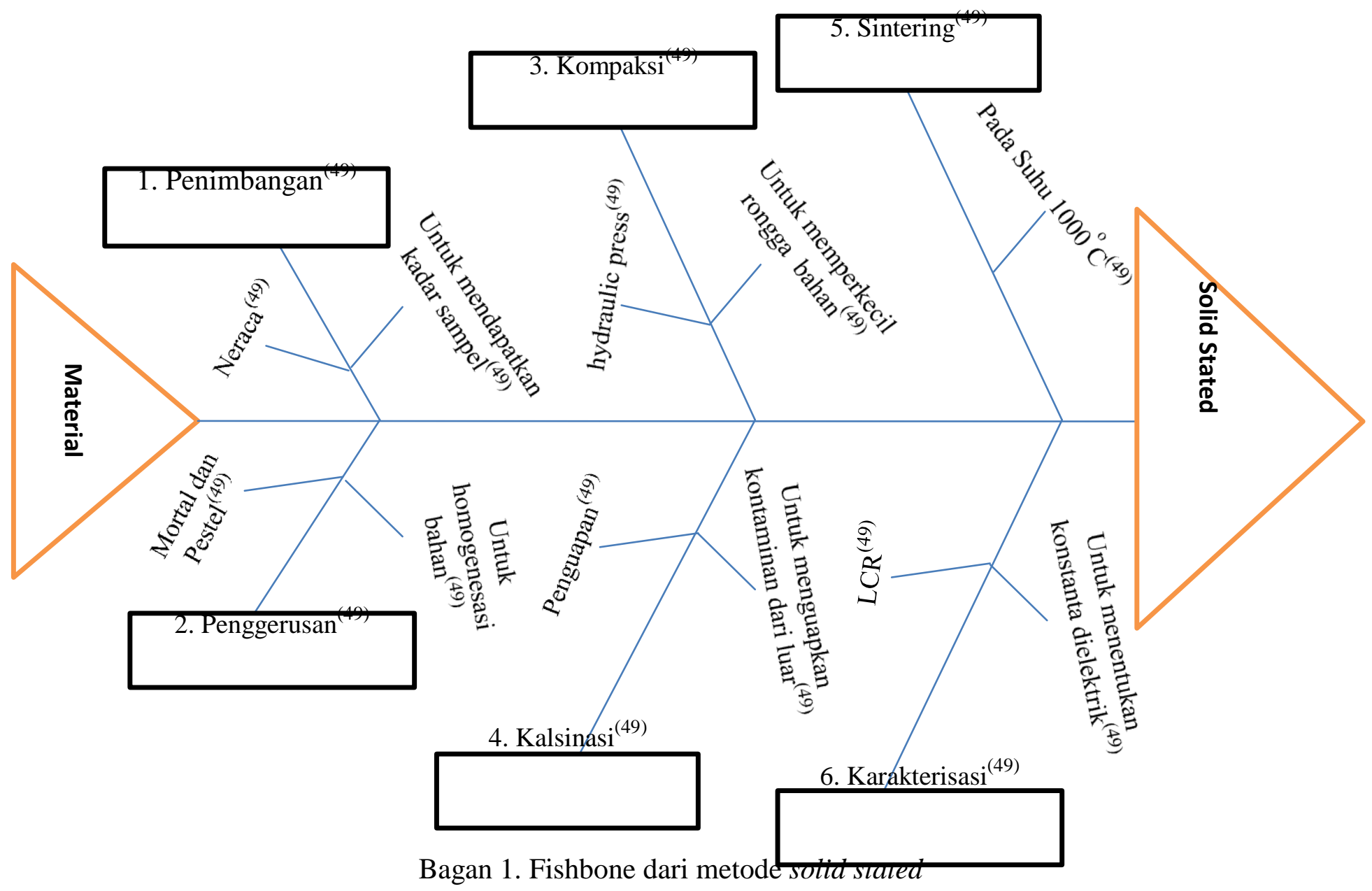

Berdasarkan fishbone di atas metode dari solid stated ini adalah mereaksikan padatan dengan padatan lainnya dengan suhu yang tinggi. Sintesis material menggunakan metode solid stated ${ }^{(49 ; 55-79)}$ ada beberapa langkah yang harus dilewati yaitu mulai dari penimbangan sampel, penggerusan sampel, kompaksi sampel, kalsinasi sampel, sintering sampel dan karakterisasi sampel. Langkah pertama yaitu penimbangan sampel, hal ini bertujuan untuk mendapatkan perbandingan suatu zat dengan zat yang lain sesuai dengan takaran yang ditentukan agar didapatkan hasil yang tepat. Proses penimbangan sampel dapat menggunakan neraca, seperti neraca digital. Langkah selanjutnya dari metode solid stated ini adalah penggerusan sampel, ini dilakukan untuk homogenesasi bahan dan membuat semua bahan dasar tercampur. Proses ini dilakukan menggunakan mortal dan pestel dan juga dapat menggunakan bar mill jika jumlah sampel yang diperlukan besar.

Selanjutnya adalah proses kompaksi sampel, yang bertujuan untuk untuk memperkecil rongga antara bahan yang masih ada pada saat dilakukan penggerusan. 
Kompaksi dilakukan menggunakan alat hydraulic press dengan memberikan tekanan yang besar yaitu 5000 psi. Setelah selesai dikompaksi selanjutnya sampel akan dikalsinasi agar kontaminan-kontaminan dari luar selama proses transportasi sampel saat penimbangan, penggerusan dan kompaksi sampel menguap ${ }^{(110)}$. Setelah itu sampel akan disintering, proses ini berlangsung pada suhu $1000^{\circ} \mathrm{C}$. Pada sintering sampel ini terjadi proses kimia antara bahan dasar sehingga menghasilkan kualitas bahan yang lebih tinggi.jika proses sintering sudah selesai maka langkah selanjutnya yaitu Karakterisasi sampel ${ }^{(49)}$. Hal ini dilakukan untuk menentukan konstanta dielektri, temperatur curie dan frekuensi dari bahan. Karakterisasi sampel dapat dilakukan menggunakan alat LCR ( inductor capasitor resistor ) dan STA ( simultaneous thermal analysis ) ${ }^{(80-95)}$

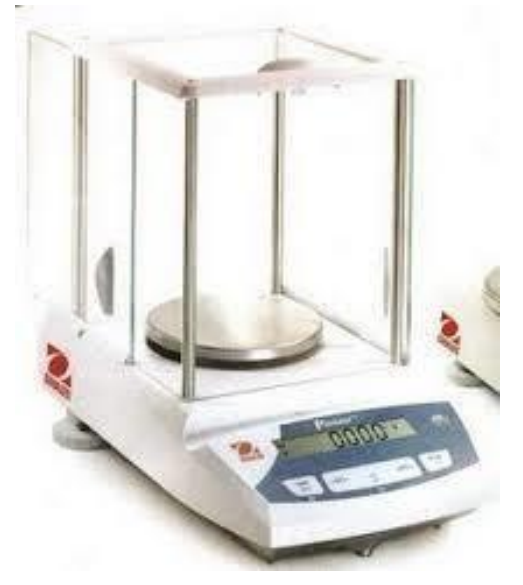

\section{Gambar 1. Neraca Digital ${ }^{(96)}$}

Gambar di atas merupakan contoh dari neraca yaitu neraca digital yang dapat digunakan dalam metode solid stated pada proses penimbangan sampel.

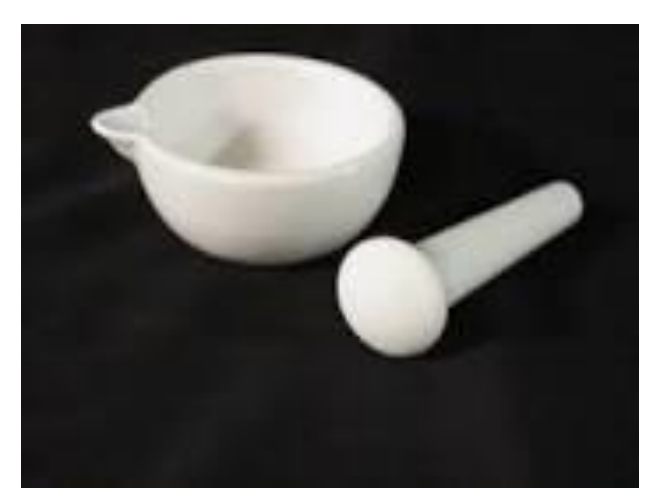

\section{Gambar 2. Mortal dan pestel ${ }^{(96)}$}

Gambar 2 merupakan alat yang digunakan dalam proses penggerusan metode solid stated yaitu mortal dan pestel. Alat ini dapat digunakan jika jumlah sampel sedikit. 


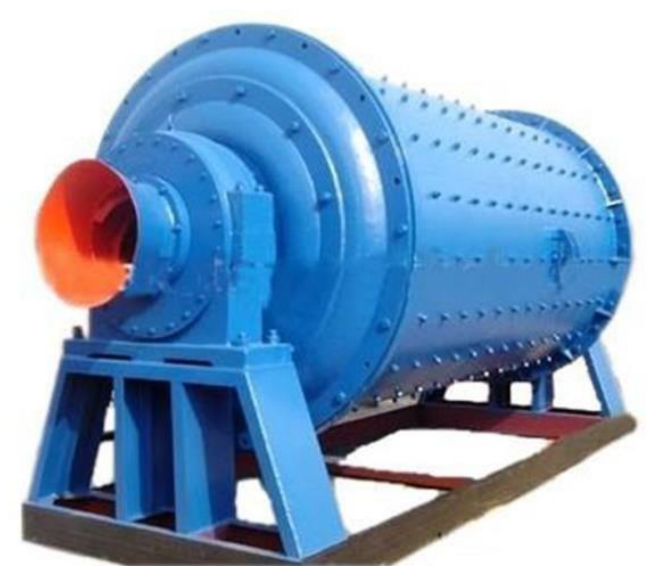

Gambar 3. Bar mill(97)

Gambar 3 ini juga digunakan dalam proses penggerusan, tetapi dalam jumlah yang besar. Nama alat ini adalah bar mill.

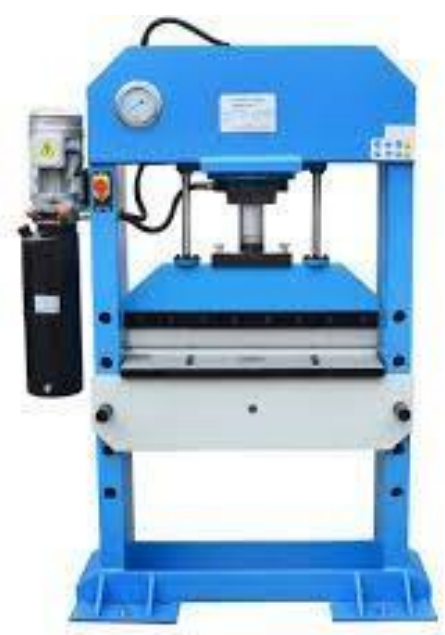

Gambar 4. hydraulic press ${ }^{(98)}$

Nama alat pada gambar 4 adalah hydraulic press, alat ini digunakan pada saat proses kompaksi sampel dalam metode solid stated 


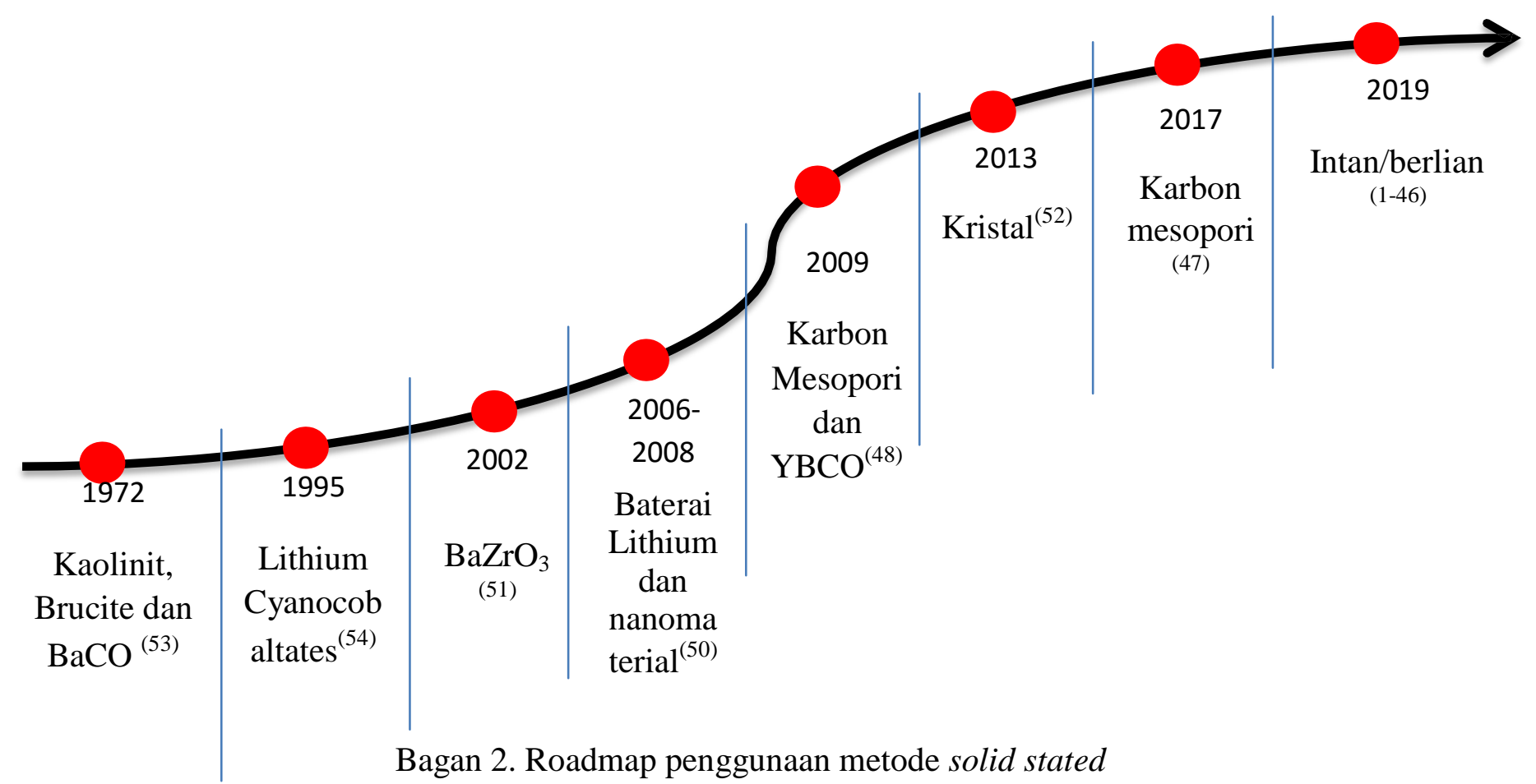

Berdasarkan roadmap di atas dapat diketahui bahwa metode solid stated sudah digunakan dalam sintesis beberapa material. Pada tahun 1972 sudah digunakan metode untuk sintesis kaolit,brucit dan BaCO. Pada tahun 1995 juga sudah digunakan Lithium Cyanoco Baltates dengan metode sintesis solid stated. Pada tahun 2002 digunakan metode solid stated pada sintesis $\mathrm{BaZrO}_{3}$, sedangkan pada tahun 2006 dan 2008 digunakan pada Baterai Lithium dan sintesis nanomaterial. Pada tahun 2009 metode solid stated digunakan pada sintesis Karbon Mesopori dan YBCO. Pada tahun 2013 ke atas metode solid stated sudah mulai berkembang, hal ini dikarenakan metode ini digunakan pada material kristal. 


\section{Pembahasan}
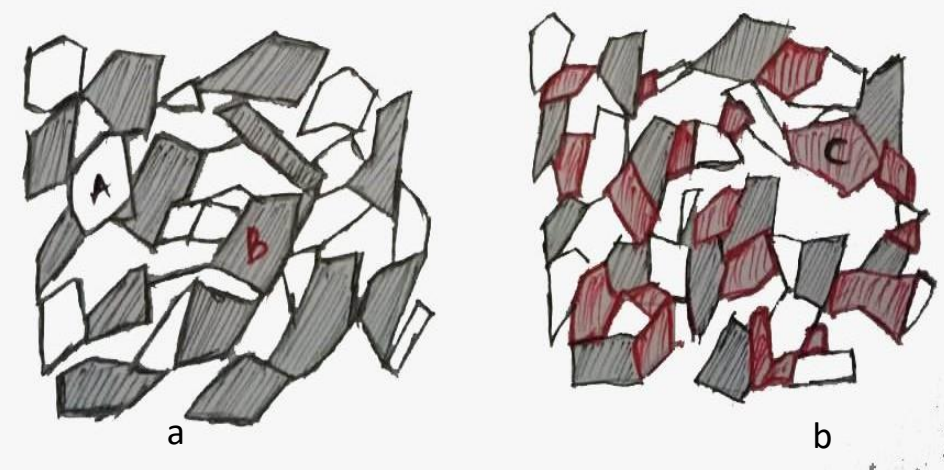

Gambar 5. Skema partikel-partikel yang bereaksi dalam reaksi solid stated, ilustrasi reaksi antara A dan B membentuk C. (a) sebelum bereaksi, (b) setelah bereaksi ${ }^{(99)}$

Skema di atas merupakan contoh keadaan campuran reaksi yang sudah diperbesar beberapa kali, pada gambar 1(a) partikel A dan partikel B membentuk campuran reaksi yang terdiri dari partikel-partikel oksida-oksida komponennya, pada gambar masih terlihat ruang kosong yang memisahkan antara partikel A dan B , namun ada beberapa partikel A dan B yang mengalami kontak permukaan dari kristal. Reaksi antara oksida-oksida biner ini terjadi dengan adanya migrasi ion-ion antara oksida-oksida murni melalui kontak permukaan tadi membentuk oksida terner dengan struktur yang baru. Sedangkan pada gambar 1(b) terlihat partikel C yang merupakan oksida terner yang terbentuk dari partikel A dan B setelah bereaksi dengan kontak permukaan kristal.

Metode keadaan padat ( solid stated) merupakan metode yang paling banyak digunakan dalam sintesis senyawa anorganik. Hal ini dikarenakan metodenya yang sederhana dan tidak banyak menggunakan prekursor. Metode solid stated ini merupakan suatu cara yang dilakukan dengan mereaksikan padatan dengan padatan lainnya dengan suhu yang tinggi. ${ }^{(100 ; 101)}$

Pada tahun 1972 metode solid stated sudah digunakan untuk mensintesis senyawa Kaolinit, Brucite dan BaCO. Pada penelitian tahun 1972 metode solid stated ini dapat membandingkan kinetika reaksi solid state isotermal berdasarkan persamaan klasik untuk analisis proses nukleasi dan pertumbuhan. Metode ini juga dapat mempermudah ketika data tidak cocok dengan persamaan reaksi yang umum digunakan, contohnya dekomposisi BaCO. Pada proses sintesisnya dibutuhkan tekanan dan suhu yang tinggi ${ }^{(53)}$

Pada tahun 1995 metode Solid Stated juga digunakan untuk mensintesis senyawa Lithium Cyanocobaltates. Proses sintesis senyawa Lithium Cyanocobaltates ini membutuhkan kapasitas yang tinggi agar dapat mengikat dioksida secara reversibel. Reversibel yaitu proses yang dapat balik tanpa menghasilkan energi. Pada sintesis ini polimer koordinasi lithium penthacyanocobaltate $\quad \mathrm{Li}_{3}\left[\mathrm{Co}(\mathrm{CN})_{5}\right] .4 \mathrm{DMF}(1, \mathrm{DMF}=\mathrm{N}, \mathrm{N}$-dimethylformamide $)$ dan $\mathrm{Li}_{3}\left[\mathrm{Co}(\mathrm{CN})_{5}\right] .2 \mathrm{DMF}$ telah disintesis dan dikarakterisasi secara struktural. Kedua senyawa 
bereaksi secara reversible dengan $\mathrm{O}_{2}$. Pada prosesnya membutuhkan suhu yang telah ditentukan $^{(54)}$

Pada tahun 2002, metode solid stated juga digunakan pada sintesis $\mathrm{BaZrO}_{3}$ menggunakan prekursor Nitrat. Penggunaan teknik reaki solid-stated yang dimodifikasi menggunakan prekursor nitrat yang mengarah ke fase Barium Metazirkonat murni yang sukses pada temperatur rendah (sekitar $800^{\circ} \mathrm{C}$ ) bubuk dengan partikel ukuran submikro dapat disintering pada densitas mendekati $1600^{\circ} \mathrm{C} / 6 \mathrm{jam}$. Selanjutnya karakterisasi sangat penting pada penggunaan $\mathrm{BaZrO}_{3}$ sebagai bahan target untuk deposisi film tipis dan sebagai bahan wadah, hal ini dikarenakan stabilitas struktural dan integritas materialnya yang luar biasa ${ }^{(51)}$

Pada tahun 2008 suatu sintesis material nanostruktul yang meliputi nanopartikel,nanotube dan komposit nanopartikel. Dengan berkembangnya suatu nanoteknologi yang digunakan oleh peneliti dan bangsawan. Sehingga pada nanopartikel memiliki sifat atau fungsi yang berbeda dari material sejenis yang berukuran besar. Proses sintesis nanopartikel dapat dilakukan secara fisika maupun kimia. Proses fisika tidak dapat mengetahui reaksi kimia hanya dapat memecahkan material yang ukuran besar menjadi ukuran nanometer serta penggabungan material yang berukuran sangat kecil. Sedangkan pada proses kimia dapat melibatkan sejumlah material awal sehingga dapat membentuk material yang lain yang berukuran nanometer. Prinsip kerja dalam metode ini melibatkan larutan polimer dengan air yang menghasilkan molekul polimer yang tinggi. Dalam melakuan pemanasan yang secara perlahan suhu dinaikan untuk menghindari pertemuan antar molekul. ${ }^{(102)}$

Pada tahun 2009 ini ada dua contoh sintesis material yang menggunakan metode solid stated yaitu Sintesis Solid Stated Karbon Mesopori dan Sintesis dan Karakterisasi YBCO Skala Nano. Pada sintesis karbon mesopori metode solid-stated merupakan metode sederhana yang hanya menggunakan phytalocyanines logam. Sebelumnya tahun 1999 sudah banyak bahan karbon mesopori yang telah disintesis menggunakan teknik replika terbalik, yang didasarkan pada inpregnasi silikat mesopori dengan prekursor karbon larut atau cairan. Namun, metode ini tidak dapat ditingkatkan ke skala yang lebih besar. Oleh karena itu pengembangan metode sintesis yang menggunakan prosedur sederhana adalah pilihan yang terbaik untuk mensintesis karbon mesopori. Beberapa rute sintesis untuk bahan karbon mesopori menggunakan grafit phytalocyanines logam. Rute dari sintesis ini yaitu penimbangan,penggerusan, kompaksi,kalsinasi, sintering dan karakterisasi ${ }^{(48)}$

Sedangkan pada Sintesis dan Karakterisasi YBCO Skala Nano. Suatu aplikasi superkonduktor ukuran nano dalam industry sangat prospektif pada masa-masa mendatang. Terutama dalam bidang industry tenaga listrik. Sintesis dan karakterisasi bulk superkonduktor sistem YBCO skala mikro dari precursor non stiokometri dan superkonduktor skala nano disintesis dari YBCO. Dimana pada metode ini superkonduktor skala nano disintesis dari

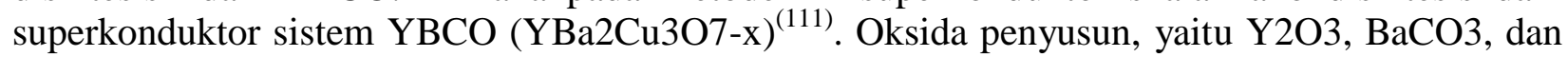
$\mathrm{CuO}$ ditimbang kemudian dicampurkan dengan media ethanol menggunakan magnetic steering sebagai pengaduk, lalu dilakukan proses kalsinasi pada $\mathrm{Tk}=900^{\circ} \mathrm{C}$ selama 5 jam , prekursor hasil dari kalsinasi ini digerus. Proses selanjutnya hasil penggerusan disintering dengan suhu dan waktu yang divariasikan. Kemudian dikarakterisasi secara kualitatif dan kuantitatif dengan teknik difraksi sinar-x metode Rietveld. Setelah melewati beberapa langkah tersebut baru didapatkan superkonduktor dalam skala nano. 
Pada tahun 2013 metode solid stated digunakan pada kimia kristal perovskite hybrid $\left(\mathrm{CH}_{3} \mathrm{NH}_{3}\right) \mathrm{Pb}^{(103)}$ untuk aplikasi sel surya. Biasanya metode solid stated digunakan untuk mensintesis material ${ }^{(104)}$. Hasil dari sintesis tersebut digunakan untuk mereaksikan suatu padatan dengan padatan lainnya. Seiring dengan berkembangnya waktu sekarang hasil dari sintesis material menggunakan metode solid state dapat diaplikasikan pada sel surya. Untuk perangkat sel surya berdasarkan metode solid stated memegang janji biaya produksi yang efektif meskipun kinerja perangkat belum tercapai. Pada penggunaan metode ini kristal perovskite hybrid $\left(\mathrm{CH}_{3} \mathrm{NH}_{3}\right) \mathrm{Pb}$ melewati proses penimbangan, penggerusan, kompaksi,kalsinasi, sintering ${ }^{(52)}$

Pada tahun 2017 dilakukan sintesis dan penerapan karbon mesopori didunia global. Mesopori berkembang melalui prekursor yang berupa sukrosa. Sukrosa adalah memiliki sifat kelarutan yang sangat baik dalam larutan air sehingga dinilai cukup kooperatif ketika direaksikan dengan molekul atau material pencetak pori. Ukuran pori dan luas permukaan karbon mesopori dapat dikontrol selama sintesis ${ }^{(104)}$. Metode sintesis mesopori yang terkenal dengan cetakan . Dimana metoda cetakan ini merupakan contoh metoda solid stated. Cetakan terbagi menjadi dua yaitu cetakan padat (hard template) dan cetakan lunak(soft template). Dalam beberapa penelitian menyatakan bahwa cetakan lunak sangat susah untuk mendapatkan struktur yang diinginkan sedang cetakan padat sangat mudah untuk mendapatkan struktur yang diinginkan ,jadi di beberapa tahun ini menggunakan cetakan padat dalam mensintesis mesopori. Sesuai dengan metode solid stated, dalam proses sintesis mesopori melewati langkah-langkah yang sesuai seperti yang dijabarkan pada fishbone ${ }^{(107)}$. Dimana langkahnya yaitu memulai dari penimbangan mesopori, penggerusan, kompaksi, kalsinasi dan sintering mesopori. Pada proses sintering menggunakan suhu yang tinggi ${ }^{(47)}$.

Pada tahun 2019 dan tahun selanjutnya, metode solid stated ini dapat digunakan dalam mensintesis intan/berlian. Metode ini dapat dilakukan pada intan/berlian karena biasanya dalam mensintesis intan/berlian ini digunakan metode vapor deposition ${ }^{(116)}$. Metode vapor deposition ini juga menggunakan suhu dan tekanan yang sangat tinggi. Penggunaan suhu yang sama-sama tinggi dengan metode solid stated, maka dalam sintesis intan/berlian untuk kedepannya dapat digunakan juga metode solid stated. Metode ini juga lebih sederhana jika digunakan dalam mensintesis berlian ${ }^{(1-46 ; 105)}$.

\section{A. Tipe-tipe material padat}

Beberapa bentuk yang dapat diadopsi oleh padatan dan kegunaan bentuk itu dijelaskan sebagai berikut:

a) Kristal tunggal: bentuk ini biasanya dipilih untuk keperluan karakterisasi struktur dan sifat.

b) Serbuk polikristalin (kristalinitas tinggi): serbuk polikristalin sering digunakan untuk karakterisasi struktur dan sifat bila kristal tunggal tidak mungkin didapatkan. Tipe serbuk ini juga disukai untuk produksi di industri maupun dalam aplikasi tertentu. 
c) Serbuk polikristalin (dengan luas permukaan besar): serbuk ini diinginkan untuk reaksi lebih lanjut dan aplikasi tertentu seperti katalisis dan bahan elektroda.

d) Amorf (gelas): amorf tidak memiliki keteraturan translasi berorde panjang dan umumnya digunakan untuk aplikasi yang memerlukan keunggulan sifat optis dan konduktor ionik.

e) Film-tipis: film tipis digunakan secara luas dalam mikroelektronik dan telekomunikasi

\section{B. Macam-macam metoda solid stated}

1) Metode Keramik, yaitu suatu metoda reaksi antar padatan yang secara langsung menghasilkan produk akhir. Pada dasarnya reaksi ini tidak melibatkan dekomposisi bahan.

Beberapa contoh reaksi dari metode keramik adalah sebagai berikut :

a) Dekomposisi, yaitu reaksi kimia dimana senyawa tunggal terurai menjadi dua atau lebih unsur atau senyawa baru

Contoh :

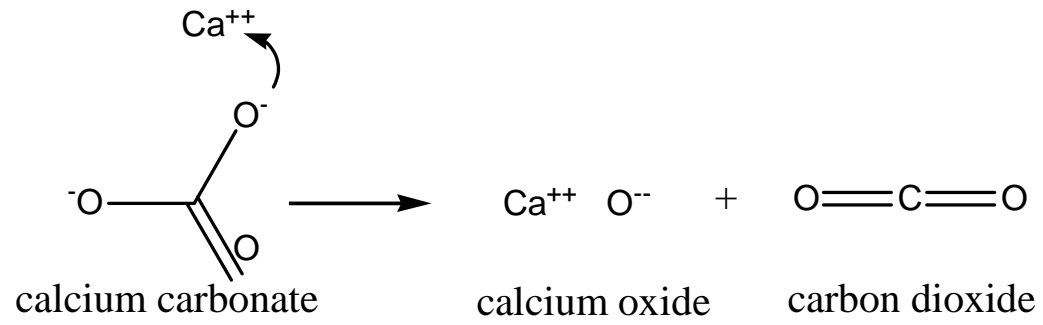

b) Kombinasi, yaitu reaksi sintesis, dua atau lebih senyawa kimia sederhana bergabung untuk membentuk produk yang lebih kompleks.

Contoh: $\mathrm{YBa}_{2} \mathrm{Cu}_{3} \mathrm{O}_{5}(\mathrm{~s})+\mathrm{O}_{2(\mathrm{~g})} \rightarrow \mathrm{YBa}_{2} \mathrm{Cu}_{3} \mathrm{O}_{7(\mathrm{~s})}$

c) Metatesis, yaitu reaksi pertukaran pasangan ion dari dua elektrolit. Pada reaksi ini, setidaknya satu produk reaksi akan membentuk endapan, gas atau elektrolit lemah.

Contohnya :

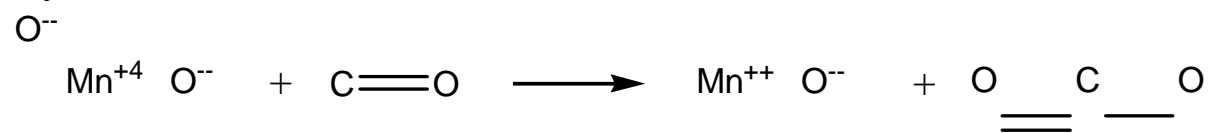

manganese dioxide carbon monoxide manganese oxide carbon dioxide

d) Adisi, yaitu reaksi penggabungan dua atau lebih molekul menjadi sebuah molekul yang lebih besar dengan disertai berkurangnya ikatan rangkap dari salah satu molekul yang bereaksi akibat adanya penggabungan ${ }^{(106)}$

Contoh : 


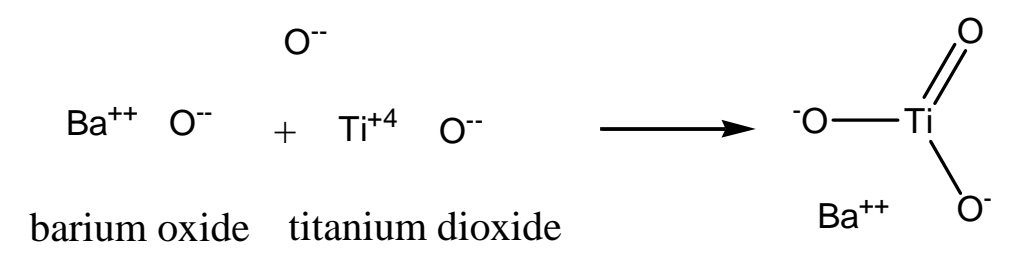

barium titanate

2) Metode formation of perovskite, yaitu struktur susunan kristal ion secara alami akan stabil bila ikatan kuat diantara ion-ion dan bila jari-jari ion pembentuk tersebut pada daerah yang sesuai.

Contoh reaksi perovskite :

Sintesis barium titanite

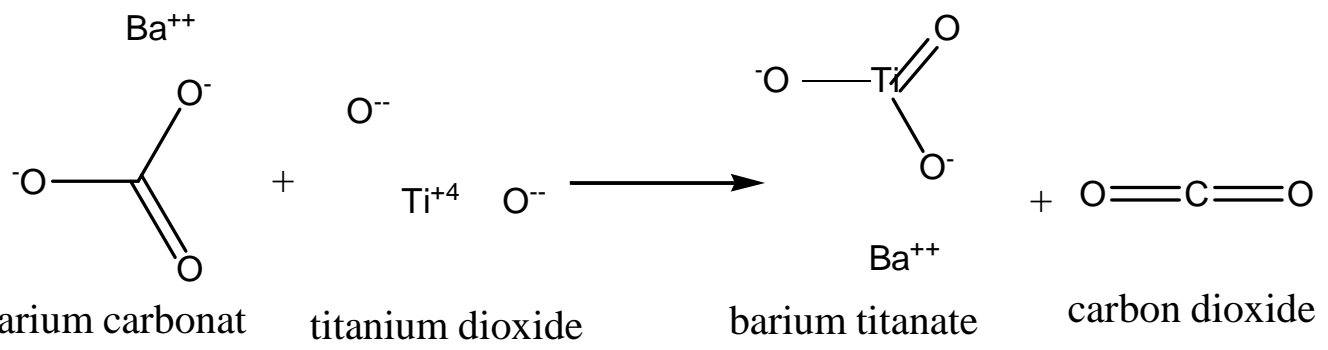

3) Metode Spinel

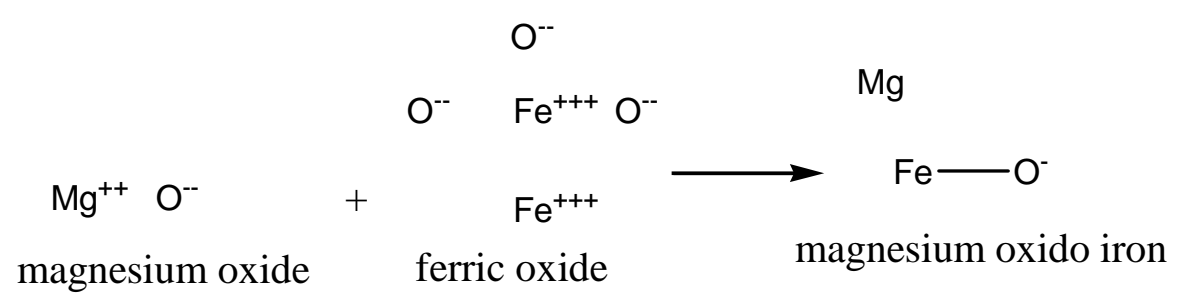

\section{Faktor yang mempengaruhi metode soilid stated}

Dalam menggunakan metode solid stated ditentukan oleh tiga faktor yaitu :

a. Luas kontak padatan pereksi

Pereaksi yang memiliki luas permukaan besar diperlukan untuk memaksimalkan jalannya reaksi. Cara untuk memaksimalkan luas kontak tersebut adalah dengan membuat pelet dari campuran-campuran pereaksi.

b. Laju difusi

Peningkatan laju difusi dapat dilakukan dengan menaikkan suhu reaksi dan memasukkan defek. Defek dapat dimasukkan dengan memulai reaksi dengan reagen yang terdekomposisi dulu sebelum atau selama bereaksi, misalnya nitrat atau karbonat.

c. Laju nukleasi fasa produk 
Peningkatan laju nukleasi fasa produk dapat dilakukan dengan menggunakan reaktan yang memiliki struktur kristal mirip dengan struktur kristal produk ( reaksi topotaktik dan epitaktik )

\section{Keuntungan dan Kelemahan dari Metode Solid Stated}

Keuntungan dari metode solid stated adalah :

a) Metodenya sederhana

Yaitu melewati proses penimbangan,penggerusan, kompkasi, kalsinasi, sintering, karakterisasi.

b) Tidak memerlukan banyak prekursor

Dalam metode ini hanya menggunakan satu atau dua prekursor saja.

Kelemahan dari metode ini adalah :

a) Membutuhkan temperatur tinggi

Pada metode ini membutuhkan temperatur yang tinggi untuk mereaksikan suatu zat padat dengan zat padat lainnya. Jika tidak maka proses laju reaksi akan lambat atau bahkan tidak terjadi.

b) Waktu reaksi sangat panjang

Dalam mereaksikan zat dibutuhkan waktu yang sangat panjang dalam metode ini, hal ini disebabkan karena untuk mencapai suhu yang tinggi membutuhkan waktu yang lama.

c) Produk tidak homogen dalam komposisi

Pada metode ini biasanya ada beberapa produk hasil reaksi yang tidak tercampur dengan baik atau homogen.

d) Fasa dapat terdekomposisi pada temperatur tinggi

Hal ini disebabkan karena ada beberapa senyawa yang memiliki titik didih yang rendah jika mengalami pemanasan dengan temperatur yanng tinggi maka senyawa itu dapat terdekomposisi.

\section{Kesimpulan}

Solid stated merupakan suatu metode yang digunakan untuk mensintesis senyawa anorganik maupun organik. Solid stated juga mempunyai keuntungan yaitu metodenya sederhana dan tidak banyak menggunakan prekursor,sedangkan kelemahan dari metode ini diantaranya reaksi harus berlangsung pada temperatur tinggi yaitu $1000^{\circ} \mathrm{C}$ hingga $1500{ }^{\circ} \mathrm{C}$, jika temperatur rendah dari itu maka laju reaksi akan rendah. Solid Stated sudah digunakan untuk berbagai macam senyawa anorganik, hal ini dibuktikan sudah adanya penelitian yang menggunakan metode ini baik dari tahun 1972 sampai pada saat sekarang ini. 


\section{Reference}

1. Baker PA, Catledge SA, Harris SB, Ham KJ, Chen WC, et al. 2018. Computational Predictions and Microwave Plasma Synthesis of Superhard Boron-Carbon Materials. Materials 11

2. Basso L, Gorrini F, Cazzanelli M, Bazzanella N, Bifone A, Miotello A. 2018. An alloptical single-step process for production of nanometric-sized fluorescent diamonds. Nanoscale 10:5738-44

3. Bonnet R, Farre C, Valera L, Vossier L, Leon F, et al. 2018. Highly labeled methylene blue-ds DNA silica nanoparticles for signal enhancement of immunoassays: application to the sensitive detection of bacteria in human platelet concentrates. The Analyst 143:2293-303

4. Buessen FL, Hering M, Reuther J, Trebst S. 2018. Quantum Spin Liquids in Frustrated Spin-1 Diamond Antiferromagnets. Physical review letters 120:057201

5. Bundaleska N, Tsyganov D, Dias A, Felizardo E, Henriques J, et al. 2018. Microwave plasma enabled synthesis of free standing carbon nanostructures at atmospheric pressure conditions. Physical chemistry chemical physics : PCCP 20:13810-24

6. Bykov M, Bykova E, Aprilis G, Glazyrin K, Koemets E, et al. 2018. Fe-N system at high pressure reveals a compound featuring polymeric nitrogen chains. Nature communications 9:2756

7. Bykov M, Bykova E, Koemets E, Fedotenko T, Aprilis G, et al. 2018. High-Pressure Synthesis of a Nitrogen-Rich Inclusion Compound ReN8 x N2 with Conjugated Polymeric Nitrogen Chains. Angewandte Chemie 57:9048-53

8. Cai J, Zhou M, Liu Y, Savall A, Groenen Serrano K. 2018. Indirect electrochemical oxidation of 2,4-dichlorophenoxyacetic acid using electrochemically-generated persulfate. Chemosphere 204:163-9

9. Cai P, Mao X, Zhao J, Luo L. 2018. Ribosome biogenesis protein Urb2 regulates hematopoietic stem cells development via P53 pathway in zebrafish. Biochemical and biophysical research communications 497:776-82

10. Calo E, Gu B, Bowen ME, Aryan F, Zalc A, et al. 2018. Tissue-selective effects of nucleolar stress and rDNA damage in developmental disorders. Nature 554:112-7

11. Chakraborty A, Uechi T, Nakajima Y, Gazda HT, O'Donohue MF, et al. 2018. Cross talk between TP53 and c-Myc in the pathophysiology of Diamond-Blackfan anemia: Evidence from RPL11-deficient in vivo and in vitro models. Biochemical and biophysical research communications 495:1839-45

12. Chen M, Shu J, Mao HK, Xie X, Hemley RJ. 2003. Natural occurrence and synthesis of two new postspinel polymorphs of chromite. Proceedings of the National Academy of Sciences of the United States of America 100:14651-4

13. Chen X, Bu X, Wang Y, Lin Q, Feng P. 2018. Charge- and Size-Complementary Multimetal-Induced Morphology and Phase Control in Zeolite-Type Metal Chalcogenides. Chemistry 24:10812-9

14. Darensbourg DJ, Adams MJ, Yarbrough JC, Phelps AL. 2003. Synthesis and structural characterization of double metal cyanides of iron and zinc: catalyst precursors for the copolymerization of carbon dioxide and epoxides. Inorganic chemistry 42:7809-18

15. Gebbie MA, Ishiwata H, McQuade PJ, Petrak V, Taylor A, et al. 2018. Experimental measurement of the diamond nucleation landscape reveals classical and nonclassical 
features. Proceedings of the National Academy of Sciences of the United States of America 115:8284-9

16. Gieshoff T, Trieu V, Heijl J, Waldvogel SR. 2018. Direct electrochemical generation of organic carbonates by dehydrogenative coupling. Beilstein journal of organic chemistry 14:1578-82

17. Guan J, Daljeet R, Kieran A, Song Y. 2018. Pressure-induced amorphization and reactivity of solid dimethyl acetylene probed by in situ FTIR and Raman spectroscopy. Journal of physics. Condensed matter : an Institute of Physics journal 30:224004

18. Haffner A, Hatz AK, Moudrakovski I, Lotsch BV, Johrendt D. 2018. Fast Sodium-Ion Conductivity in Supertetrahedral Phosphidosilicates. Angewandte Chemie 57:6155-60

19. Hanessian S, Yang Y, Giroux S, Mascitti V, Ma J, Raeppel F. 2003. Application of conformation design in acyclic stereoselection: total synthesis of borrelidin as the crystalline benzene solvate. Journal of the American Chemical Society 125:13784-92

20. Konar S, Zangrando E, Drew MG, Ribas J, Chaudhuri NR. 2004. Synthesis, structural analysis, and magnetic behaviour of three fumarate bridged coordination polymers: fivefold interpenetrated diamond-like net of NiII, sheets of NiII and CoII. Dalton transactions:260-6

21. Laniel D, Dewaele A, Garbarino G. 2018. High Pressure and High Temperature Synthesis of the Iron Pernitride FeN2. Inorganic chemistry 57:6245-51

22. Laniel D, Weck G, Loubeyre P. 2018. Direct Reaction of Nitrogen and Lithium up to 75 GPa: Synthesis of the Li3N, LiN, LiN2, and LiN5 Compounds. Inorganic chemistry 57:10685-93

23. Li J, Cao K, Li J, Liu M, Zhang S, et al. 2018. Synthesis and Ceramic Conversion of a New Organodecaborane Preceramic Polymer with High-Ceramic-Yield. Molecules 23

24. Li S, Bandy JA, Hamers RJ. 2018. Enhanced Photocatalytic Activity of Diamond Thin Films Using Embedded Ag Nanoparticles. ACS applied materials \& interfaces 10:5395403

25. Lou Z, Chen Q, Zhang Y, Wang W, Qian Y. 2003. Diamond formation by reduction of carbon dioxide at low temperatures. Journal of the American Chemical Society 125:93023

26. Ma BQ, Sun HL, Gao S. 2003. The design and synthesis of a non-centric diamond-like network based NH4+ ion. Chemical communications:2164-5

27. Moreno AJ, Lo Verso F. 2018. Computational investigation of microgels: synthesis and effect of the microstructure on the deswelling behavior. Soft matter 14:7083-96

28. Pandolfi S, Renero-Lecuna C, Le Godec Y, Baptiste B, Menguy N, et al. 2018. Nature of Hexagonal Silicon Forming via High-Pressure Synthesis: Nanostructured Hexagonal 4H Polytype. Nano letters

29. Purdy AP, Butcher RJ, Yesinowski JP, Fischer SA, Gunlycke D, Chaloux BL. 2018. Synthesis and Structure of Sn14Cl6(CH2SiMe3)12: Toward Nanoclusters of 4Coordinate alpha-Sn. Inorganic chemistry 57:4921-5

30. Ronca A, Ronca S, Forte G, Zeppetelli S, Gloria A, et al. 2018. Synthesis and characterization of divinyl-fumarate poly-epsilon-caprolactone for scaffolds with controlled architectures. Journal of tissue engineering and regenerative medicine 12:e523-e31 
31. Sankaran KJ, Panda K, Hsieh PY, Pobedinskas P, Park JY, et al. 2018. Low Temperature Synthesis of Lithium-Doped Nanocrystalline Diamond Films with Enhanced Field Electron Emission Properties. Nanomaterials 8

32. Shiraki K, Tsuchiya T, Ono S. 2003. Structural refinements of high-pressure phases in germanium dioxide. Acta crystallographica. Section B, Structural science 59:701-8

33. Sung HJ, Han WH, Lee IH, Chang KJ. 2018. Superconducting Open-Framework Allotrope of Silicon at Ambient Pressure. Physical review letters 120:157001

34. Tamerius AD, Clarke SM, Gu M, Walsh JPS, Esters M, et al. 2018. Discovery of Cu3Pb. Angewandte Chemie 57:12809-13

35. Terrones M, Terrones H. 2003. The carbon nanocosmos: novel materials for the twentyfirst century. Philosophical transactions. Series A, Mathematical, physical, and engineering sciences 361:2789-806

36. Tsubota T, Morioka A, Osoekawa Y, Nakao M. 2018. Direct Synthesis of Graphene Layer Covered Micro Channel on Diamond Surface Using Ni Wire. Journal of nanoscience and nanotechnology 18:4418-22

37. Walsh JPS, Freedman DE. 2018. High-Pressure Synthesis: A New Frontier in the Search for Next-Generation Intermetallic Compounds. Accounts of chemical research 51:131523

38. Wang AJ, Zhang KX, Gao YL, Weng AZ, Wang LY, et al. 2018. Synthesis and bioactivity studies of sex pheromone analogs of the diamond back moth, Plutella xylostella. Pest management science

39. Wang T, Handschuh-Wang S, Huang L, Zhang L, Jiang X, et al. 2018. Controlling Directional Liquid Motion on Micro- and Nanocrystalline Diamond/beta-SiC Composite Gradient Films. Langmuir : the ACS journal of surfaces and colloids 34:1419-28

40. Wang Y, Jiang SQ, Goncharov AF, Gorelli FA, Chen XJ, et al. 2018. Synthesis and Raman spectroscopy of a layered SiS2 phase at high pressures. The Journal of chemical physics 148:014503

41. Wilts BD, Saranathan V. 2018. A Literal Elytral Rainbow: Tunable Structural Colors Using Single Diamond Biophotonic Crystals in Pachyrrhynchus congestus Weevils. Small:e1802328

42. Yamamoto T, Riehl B, Naba K, Nakahara K, Wiebe A, et al. 2018. A solvent-directed stereoselective and electrocatalytic synthesis of diisoeugenol. Chemical communications 54:2771-3

43. Yang P, Huang N, Leng YX, Chen JY, Fu RK, et al. 2003. Activation of platelets adhered on amorphous hydrogenated carbon (a-C:H) films synthesized by plasma immersion ion implantation-deposition (PIII-D). Biomaterials 24:2821-9

44. Ye R, Han X, Kosynkin DV, Li Y, Zhang C, et al. 2018. Laser-Induced Conversion of Teflon into Fluorinated Nanodiamonds or Fluorinated Graphene. ACS nano 12:1083-8

45. Zerr A, Miehe G, Riedel R. 2003. Synthesis of cubic zirconium and hafnium nitride having Th3P4 structure. Nature materials 2:185-9

46. Zheng Q, Polanco CA, Du MH, Lindsay LR, Chi M, et al. 2018. Antisite Pairs Suppress the Thermal Conductivity of BAs. Physical review letters 121:105901

47. Ulfa M. 2017. Mesoporous Carbon in the Global World. Jurnal Kimia Dan Pendidikan Kimia Vol 2, No 1:54-65

48. Ohta N, Takada K, Zhang L, Ma R, Osada M, Sasaki T. 2009. Enhancement of the HighRate Capability of Solid-State Lithium Batteries by Nanoscale Interfacial Modification. 
49. Uchi Delfia AM, Syahfandi Ahda. 2014. Pengaruh Penambahan $\mathrm{SrTiO}_{3}$ Pada Struktur dan Sifat Listrik Bahan Piezoelektrik BNT-BT.

50. Ohta N, Takada K, Zhang L, Ma R, Osada M, Sasaki T. 2006. Enhancement of the HighRate Capability of Solid-State Lithium Batteries by Nanoscale Interfacial Modification.

51. Azad AM, Subramaniam S. 2002. Synthesis Of BaZrO3 by A Solid-state Reaction Technique Using Nitratre Prekursors. Matrial research bulletin Vol.37:85-97

52. Baikie T, Fang Y, Kadro JM, Schreyer M, Wei F, et al. 2013. Synthesis and crystal chemistry of the hybrid perovskite $(\mathrm{CH} 3 \mathrm{NH} 3) \mathrm{PbI} 3$ for solid-state sensitised solar cell applications $\dagger$.

53. SHARP JDHaJH. 1972. Method of Comparing Solid-state Kinetic Data and Its Application to the Decomposition of Kaolinite, Brucite, and $\mathrm{BaCO}$,. Journal of The American Ceramic Society Vol. 55, No. 2

54. Ramprasad D, Guido P. Pez BHT, Markley TJ, Pearlstein RM. 1995. Solid State Lithium Cyanocobaltates with a High Capacity for Reversible Dioxygen Binding: Synthesis, Reactivity, and Structures. American Chemical Society Vol. 117, No. 43, 1995

55. Al-Tannak NF. 2018. UHPLC-UV Method for Simultaneous Determination of Perindopril Arginine and Indapamide Hemihydrate in Combined Dosage Form: A Stability-Indicating Assay Method. Scientia pharmaceutica 86

56. Aziz HA, Puat NNA, Alazaiza MYD, Hung YT. 2018. Poultry Slaughterhouse Wastewater Treatment Using Submerged Fibers in an Attached Growth Sequential Batch Reactor. International journal of environmental research and public health 15

57. Brockmann JG, Broering DC, Raza SM, Rasheed W, Hashmi SK, et al. 2018. Solid organ transplantation following allogeneic haematopoietic cell transplantation: experience from a referral organ transplantation center and systematic review of literature. Bone marrow transplantation

58. Czigany Z, Scherer MN, Pratschke J, Guba M, Nadalin S, et al. 2018. Technical Aspects of Orthotopic Liver Transplantation-a Survey-Based Study Within the Eurotransplant, Swisstransplant, Scandiatransplant, and British Transplantation Society Networks. Journal of gastrointestinal surgery : official journal of the Society for Surgery of the Alimentary Tract

59. De Feo G, De Gisi S, De Vita S, Notarnicola M. 2018. Sustainability assessment of alternative end-uses for disused areas based on multi-criteria decision-making method. The Science of the total environment 631-632:142-52

60. Defois C, Ratel J, Garrait G, Denis S, Le Goff O, et al. 2018. Food Chemicals Disrupt Human Gut Microbiota Activity And Impact Intestinal Homeostasis As Revealed By In Vitro Systems. Scientific reports 8:11006

61. Garrudo-Guirado MI, Blanco-Flores A, Toledo-Jaldin HP, Sanchez-Mendieta V, VilchisNestor AR. 2018. Reuse of sustainable materials for xylenol orange dye and copper (II) ion ammoniacal removal. Journal of environmental management 206:920-8

62. Hu EM, Zhang A, Silverman SG, Pedrosa I, Wang ZJ, et al. 2018. Multi-institutional analysis of CT and MRI reports evaluating indeterminate renal masses: comparison to a national survey investigating desired report elements. Abdominal radiology

63. Itou H, Kovtunenko VA, Rajagopal KR. 2018. On the states of stress and strain adjacent to a crack in a strain-limiting viscoelastic body. Mathematics and mechanics of solids : $M M S$

23:433-44 
64. Jendrzejewska I, Zajdel P, Pietrasik E, Barsova Z, Goryczka T. 2018. Application of Xray powder diffraction and differential scanning calorimetry for identification of counterfeit drugs. Monatshefte fur chemie 149:977-85

65. Jing D, Song S, Pan Y, Wang X. 2018. Optimal fractal tree-like microchannel networks with slip for laminar-flow-modified Murray's law. Beilstein journal of nanotechnology 9:482-9

66. Jo Y, Benoist DM, Ameerally A, Drake MA. 2018. Sensory and chemical properties of Gouda cheese. Journal of dairy science 101:1967-89

67. Khaled SA, Alexander MR, Irvine DJ, Wildman RD, Wallace MJ, et al. 2018. Extrusion 3D Printing of Paracetamol Tablets from a Single Formulation with Tunable Release Profiles Through Control of Tablet Geometry. AAPS PharmSciTech

68. Li Y, Luo W, Lu J, Zhang X, Li S, et al. 2018. Effects of digestion time in anaerobic digestion on subsequent digestate composting. Bioresource technology 267:117-25

69. Lozanov VV, Baklanova NI, Bulina NV, Titov AT. 2018. New Ablation-Resistant Material Candidate for Hypersonic Applications: Synthesis, Composition, and Oxidation Resistance of HfIr3-Based Solid Solution. ACS applied materials \& interfaces 10:1306272

70. Ludasi K, Sovany T, Laczkovich O, Hopp B, Smausz T, Regdon G, Jr. 2018. Unique laser coding technology to fight falsified medicines. European journal of pharmaceutical sciences : official journal of the European Federation for Pharmaceutical Sciences 123:1-9

71. Montoya P, Henao K, Perez G, Salazar CA, Calderon J. 2018. Assessment of the moisturizing properties of a magnetic mask containing iron oxide particles. Journal of cosmetic dermatology

72. Nakanuma Y, Jang KT, Fukushima N, Furukawa T, Hong SM, et al. 2018. A statement by the Japan-Korea expert pathologists for future clinicopathological and molecular analyses toward consensus building of intraductal papillary neoplasm of the bile duct through several opinions at the present stage. Journal of hepato-biliary-pancreatic sciences $25: 181-7$

73. Nowak S, Winter M. 2018. The Role of Cations on the Performance of Lithium Ion Batteries: A Quantitative Analytical Approach. Accounts of chemical research 51:265-72

74. Ogata M, Phan T, Fukuda T. 2018. Antiviral Therapy for the Treatment of HHV-6Associated Syndromes after Transplantation. American journal of transplantation : official journal of the American Society of Transplantation and the American Society of Transplant Surgeons

75. Poppinga D, Delfs B, Meyners J, Langner F, Giesen U, et al. 2018. Determination of the active volumes of solid-state photon-beam dosimetry detectors using the PTB proton microbeam. Medical physics 45:3340-8

76. Rezaeeyan H, Shahrabi S, McKee TD, Saki N. 2018. The expression of CD markers in solid tumors: Significance in metastasis and prognostic value. Histology and histopathology:11981

77. Tuncer Vural A, Karatas Togral A, Kirnap M, Gulec AT, Haberal M. 2018. Skin Cancer Risk Awareness and Sun-Protective Behavior Among Solid-Organ Transplant Recipients. Experimental and clinical transplantation : official journal of the Middle East Society for Organ

Transplantation

16

Suppl

1:203-7 
78. Zainul R. 2016. Effect of Temperature and Particle Motion against the ability of $\mathrm{ZnO}$ Semiconductor Photocatalyst in Humic Acid

79. Zwiener L, Girgsdies F, Schlogl R, Frei E. 2018. Investigations of Cu/Zn Oxalates from Aqueous Solution: Single Phase Precursors and Beyond. Chemistry

80. Missotten JA, Michiels J, Ovyn A, De Smet S, Dierick NA. 2010. Fermented liquid feed for pigs. Archives of animal nutrition 64:437-66

81. Garnero C, Zoppi A, Genovese D, Longhi M. 2010. Studies on trimethoprim:hydroxypropyl-beta-cyclodextrin: aggregate and complex formation. Carbohydrate research 345:2550-6

82. Gautam V, Thapar R, Sharma M. 2010. Biomedical waste management: incineration vs. environmental safety. Indian journal of medical microbiology 28:191-2

83. Marsh GM, Youk AO, Morfeld P, Collins JJ, Symons JM. 2010. Incomplete follow-up in the National Cancer Institute's formaldehyde worker study and the impact on subsequent reanalyses and causal evaluations. Regulatory toxicology and pharmacology : RTP 58:233-6

84. Dillon JE, Slanetz PJ. 2010. Teaching evidence-based imaging in the radiology clerkship using the ACR appropriateness criteria. Academic radiology 17:912-6

85. Marciniec B, Stawny M, Danikiewicz W, Spolnik G, Jaroszkiewicz E, Needham M. 2010. Identification of radiolysis products of solid thiamphenicol. Journal of pharmaceutical and biomedical analysis 53:826-32

86. Gemmei-Ide M, Ohya A, Kitano H. 2010. Thermally latent water in a polymer matrix. The journal of physical chemistry. B 114:4310-2

87. Quetel CR, Vassileva E, Petrov I, Chakarova K, Hadjiivanov KI. 2010. First results on Fe solid-phase extraction from coastal seawater using anatase $\mathrm{TiO} 2$ nano-particles. Analytical and bioanalytical chemistry 396:2349-61

88. Nakkeeran E, Subramanian R, Umesh-Kumar S. 2010. Purification of polygalacturonase from solid-state cultures of Aspergillus carbonarius. Journal of bioscience and bioengineering 109:101-6

89. Aps JK. 2010. Flemish general dental practitioners' knowledge of dental radiology. Dento maxillo facial radiology 39:113-8

90. Chung SS, Lau KY, Zhang C. 2010. Measuring bulky waste arisings in Hong Kong. Waste management 30:737-43

91. Jaenish R. 2010. Virus, development and pluripotent stem cells - an interview with Rudolf Jaenisch. The International journal of developmental biology 54:1597-607

92. Wirth R, Bauer JM, Willschrei HP, Volkert D, Sieber CC. 2010. Prevalence of percutaneous endoscopic gastrostomy in nursing home residents--a nationwide survey in Germany. Gerontology 56:371-7

93. Qian F, Wang H. 2010. Study of the filtration performance of a plain wave fabric filter using response surface methodology. Journal of hazardous materials 176:559-68

94. Joo S, Kim KH, Kim HC, Chung TD. 2010. A portable microfluidic flow cytometer based on simultaneous detection of impedance and fluorescence. Biosensors \& bioelectronics 25:1509-15

95. Sattler UG, Hirschhaeuser F, Mueller-Klieser WF. 2010. Manipulation of glycolysis in malignant tumors: fantasy or therapy? Current medicinal chemistry 17:96-108

96. http://chanif93.blogspot.com/2013/07/peralatan-laboratorium-dan-fungsinya.html

97. http://www.ballmillfactory.com/grinding-plant/rod-mill.html 
98. https://www.kawanlama.com/hydraulic-press-machine-100t-w-ac.html

99. Ismunandar. 2006. Padatan Oksida Logam : Struktur, sintesis dan sifat-sifatnya. Bandung ITB

100. Rahadian Z. 2015. Disain dan Modifikasi Kolektor dan Reflektor Cahaya pada Panel Sel Surya Al/Cu2O-Gel Na2SO4.

101. Mawardi M, Deyundha D, Zainul R, P RZ. 2018. Characterization of PCC Cement by Addition of Napa Soil from Subdistrict Sarilamak 50 Kota District as Alternative Additional Material for Semen Padang. IOP Conf. Series: Materials Science and Engineering 335

102. Zainul R, Oktavia B, Dewata I, Efendi J. 2018. Thermal and Surface Evaluation on The Process of Forming a Cu2O/CuO Semiconductor Photocatalyst on a Thin Copper Plate. IOP Conf. Series: Materials Science and Engineering 335

103. Anwar M, Munaf E, Kosela S, Wibowo W, Zainul R. 2015. Study of Pb(II) biosorption from aqueous solution using immobilized Spirogyra subsalsa biomass Journal of Chemical and Pharmaceutical Research 7(11):715-722

104. Kurniawati D, Zein, R., Chaidir, Z., \& Aziz, H. 2018. The Study of Blocking Agent on Lengkeng (Euphoria Logan Lour) Fruit Shell and Seed for Adsorption of $\mathrm{Pb}$ (II) from Aqueous Solution. In IOP Conference Series: Materials Science and Engineering (Vol. 335, No. 1, p. 012032). IOP Publishing.

105. Spear KE. 1989. Diamond-Ceramic Coating of the Future. j.Am.Ceram.Soc.72[2]

106. H., Sanjaya, H., \& Zainul, R. (2016, August 30). Synthesis and Electrical Properties of ZnOITO and Al-ITO thin Film by Spin Coating Technique Through Sol Gel Process. https://doi.org/10.31227/osf.io/unrt4

107. M., Sanjaya, H., \& Zainul, R. (2015, December 30). Characterization of napa soil and adsorption of $\mathrm{Pb}$ (II) from aqueous solutions using on column method. https://doi.org/10.31227/osf.io/t8fh9

108. Zainul, R., Oktavia, B., Dewata, I., \& efendi, j. (2017, February 4). Studi Dinamika Molekular dan Kinetika Reaksi pada Pembelahan Molekul Air untuk Produksi Gas Hidrogen. https://doi.org/10.31227/osf.io/876s3

109. M., Yani, S. R., \& Zainul, R. (2017, September 4). Aktivasi Tanah Napa dan Pengaruhnya Terhadap Adsorpsi Ion Timbal (II)/ $\mathrm{Pb} 2+$. https://doi.org/10.31227/osf.io/ps523

110. Chaidir, z., Fadjria, N., A., \& Zainul, R. (2016, December 5). Isolation And Molecular Identification Of Freshwater Microalgae In Maninjau Lake West Sumatera. https://doi.org/10.31227/osf.io/nbcuf

111. Anhar, A., Sumarmin, R., \& Zainul, R. (2016, August 30). Measurement of Glycemic Index of West Sumatera Local Rice Genotypes for Healthy Food Selection. https://doi.org/10.31227/osf.io/tgy8h

112. Zainul, R., \& Dewata, I. (2015, December 29). Determination of pH-BOD-COD and degradation in batang arau watersheds at Padang city. https://doi.org/10.31227/osf.io/efdzj

113. Zaimul, R. (2016, December 18). Đesign and Modification of Copper Oxide Electrodes for Improving Conversion Coefficient Indoors Lights (PV-Cell) Photocells. https://doi.org/10.31227/osf.io/pgn84 
114. Zainul, R. (2016, September 24). Determination of the half-life and the quantum yield of $\mathrm{ZnO}$ semiconductor photocatalyst in humic acid. https://doi.org/10.31227/osf.io/e8a9x

115. Zainul, R., Alif, A., Aziz, H., Arief, S., Dradjad, S., \& Munaf, E. (2015). Design of photovoltaic cell with copper oxide electrode by using indoor lights. Research Journal Of Pharmaceutical Biological And Chemical Sciences, 6(4), 353-361

116. chaidir, z., Zainul, R., Nurakhbari, D., \& Salim, M. (2016, September 24). Optimization of Spirulina Platensis Culture for Antioxidant Production. https://doi.org/10.17605/OSF.IO/FD6E4

117. Zainul, R., Alif, A., Aziz, H., \& Arief, S. (2015). Disain Geometri Reaktor Fotosel Cahaya Ruang. Jurnal Riset Kimia, 8(2), 131.

118. Zainul, R., Alif, A., Aziz, H., Arief, S., \& Darajat, S. (2015). Modifikasi dan Karakteristik IV Sel Fotovoltaik $\mathrm{Cu} 2 \mathrm{o} / \mathrm{Cu}-\mathrm{Gel} \mathrm{Na} 2 \mathrm{so} 4$ Melalui Iluminasi Lampu Neon. Eksakta, 2, 50.

119. Kurniawati, D., Zein, R., Chaidir, Z., \& Aziz, H. (2018, April). The Study of Blocking Agent on Lengkeng (Euphoria Logan Lour) Fruit Shell and Seed for Adsorption of $\mathrm{Pb}$ (II) from Aqueous Solution. In IOP Conference Series: Materials Science and Engineering (Vol. 335, No. 1, p. 012032). IOP Publishing. 


\title{
PRINSIP DASAR MILLING DALAM SINTESIS MATERIAL
}

\author{
Annisa Awalliyah ${ }^{* 1}$, Hafizah Ikhwan ${ }^{2}$, Veny Nugiasari' ${ }^{2}$, Rahadian Zainul ${ }^{2}$ \\ ${ }^{1}$ Laboratorium Kimia, FMIPA, Universitas Negeri Padang, Indonesia \\ ${ }^{2}$ Laboratorium Kimia, FMIPA, Universitas Negeri Padang, Indonesia \\ ${ }^{3}$ Laboratorium Kimia, FMIPA, Universitas Negeri Padang, Indonesia \\ ${ }^{4}$ Laboratorium Fisika, FMIPA, Universitas Negeri Padang, Indonesia
}

\section{*Email : Hellomyfabulousday@gmail.com}

\begin{abstract}
Abstrak Milling merupakan proses penguraian material yang menghasilkan bentukan bidang datar yang biasanya menggunakan proses dengan menggunakan bantuanmesin. Terdapat beberapa klasifikasi proses milling diantaranya Peripheral Milling, Face Milling, dan End Milling. Metode yang digunakan pada proses ini adalah metode pemotongan dan sistem pembagian pada mesin.Banyak faktor-faktor yang berpengaruh terhadap hasil dari proses milling ini seperti kecepatan, waktu, temperatur, tekanan, ukuran grinding ball, persentasi PCA (Process Control Agent), dan komposisi berat serbuk tersebut.
\end{abstract}

Kata kunci :Milling, metode, material, review

\section{PENDAHULUAN}

Milling merupakan proses penguraian material ${ }^{(10 ; 11)}$ yang menghasilkan bentukan bidang datar yang biasanya menggunakan proses dengan menggunakan bantuan mesin. Secara mekanik Milling merupakan teknik yang sederhana dan efektif ${ }^{(14)}$ untuk membuat ukuran kristal padat yang cukup besar menjadi lebih kecil tanpa melalui fasa penguapan atau reaksi kimia yang mana biasanya diperlukan dalam proses sintesa lainnya ${ }^{(15-17)}$. Untuk memulai proses milling ini digunakan cara yakni deformasi yang berulang-ulang dengan menghancurkan partikel serbuk sehingga partikel menjadi lebih kecil $^{(18 ; 19)}$. Pada proses ini yang digunakan adalah vial dan bola-bola yang terbuat dari stainless steel yang diperkirakan dapat menyebabkan lepasnya unsur penyusu stainless steel ke dalam bahan objek ${ }^{(20)}$. Penggunaan teknik milling dapat diketahui dengan mendapatkan informasi tentang keberadaan unsur pengotor dalam sampel hasil proses milling ${ }^{(21)}$, maka didapatkan tingkat kemurnian dari sampel hasil proses milling tersebut ${ }^{(22)}$.

Proses pemesinan milling adalah proses penyayatan benda kerja menggunakan alat pemotong dan dilengkapi mata potong jamak yang berputar. Proses penyayatan dengan gigi potong yang banyak yang mengitari pahat ini dapat menghasilkan proses pemesinan lebih cepat. Permukaan yang disayat bisa berbentuk datar, menyudut, atau melengkung. Mesin (Gambar 1) yang digunakan untuk memegang benda kerja, memutar pahat, dan penyayatannya disebut mesin frais (Milling Machine). 


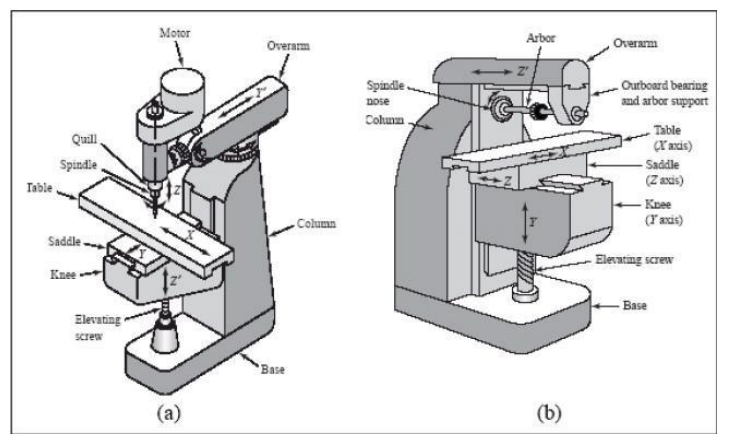

Gambar 1. Mesin Milling (Milling Frais) (23)

Terdapat beberapa klasifikasi milling yang mana pengklasifikasian ini ditentukan berdasarkan jenis pahat, arah penyayatan, dan posisi relatif pahat terhadap benda kerja. Diantara klasifikasi milling itu sendiri adalah :

1. Peripheral Milling ${ }^{(24)}$

Peripheral Milling ini sering disebut juga slab milling, permukaan yang difrais dihasilkan oleh gigi pahat yang terletak pada permukaan luar badan alat potongnya. Sumbu dari putaran pahat biasanya pada bidang yang sejajar dengan permukaan benda kerja yang disayat ${ }^{(25)}$.

2. Face Milling ${ }^{(26)}$

Pada frais muka, pahat dipasang pada spindel yang memiliki sumbu putar tegak lurus terhadap permukaan benda kerja ${ }^{(27)}$. Permukaan hasil proses frais ${ }^{(28)}$ dihasilkan dari hasil penyayatan oleh ujung dan selubung pahat.

3. End Milling

Pahat pada proses frais ujung biasanya berputar pada sumbu ${ }^{(29)}$ yang tegak lurus dengan permukaan benda kerja ${ }^{(30)}$. Pahat dapat digerakkan menyudut ${ }^{(31)}$. Gigi potong pada pahat terletak pada selubung pahat dan ujung badan pahat.

Dalam sintesis ${ }^{(32)}$ material yang sering digunakan dalam proses milling yakni menggunakan Ball Mill ${ }^{(33)}$ dan CNC Mill. Ball Mill merupakan salah satu mesin pengolahan material ${ }^{(34)}$ yang berfungsi menghaluskan formula material tersebut dengan menggunakan bola-bola stainless steel ${ }^{(35)}$ yang ada pada tabung penghalusan. Ball Mill tersebut terbuat dari logam ${ }^{(36)}$ yang disyaratkan mempunyai karakteristik keras ${ }^{(37)}$ sekaligus tangguh (tidak mudah pecah) dan tahan korosi ${ }^{(38)}$ untuk menanggung beban dan lingkungan selama proses penggilingan materi.Banyak faktor-faktor yang berpengaruh terhadap hasil dari proses milling ini seperti kecepatan ${ }^{(39)}$, waktu, temperatur $^{(40)}$, tekanan, ukuran grinding ball, persentasi PCA (Process Control Agent), dan komposisi berat serbuk tersebut.

CNC (Computer Numerical Control) adalah mesin milling dimana pergerakan meja mesinnya dikendalikan dalam suatu program. Program tersebut berisi langkahlangkah perintah yang harus dijalankan oleh mesin CNC. Terdapat beberapa komponen mesin $\mathrm{CNC}$ antara lain meja mesin, spindel mesin, magasin tool, monitor, panel control, coolant hose. 


\section{METODE}

Metode $^{(41)}$ yang digunakan pada proses milling ditentukan berdasarkan arah relatif gerak makan meja mesin fraisterhadap putaran pahat. Terdapat 2 macam metode yang digunakan pada proses ini :
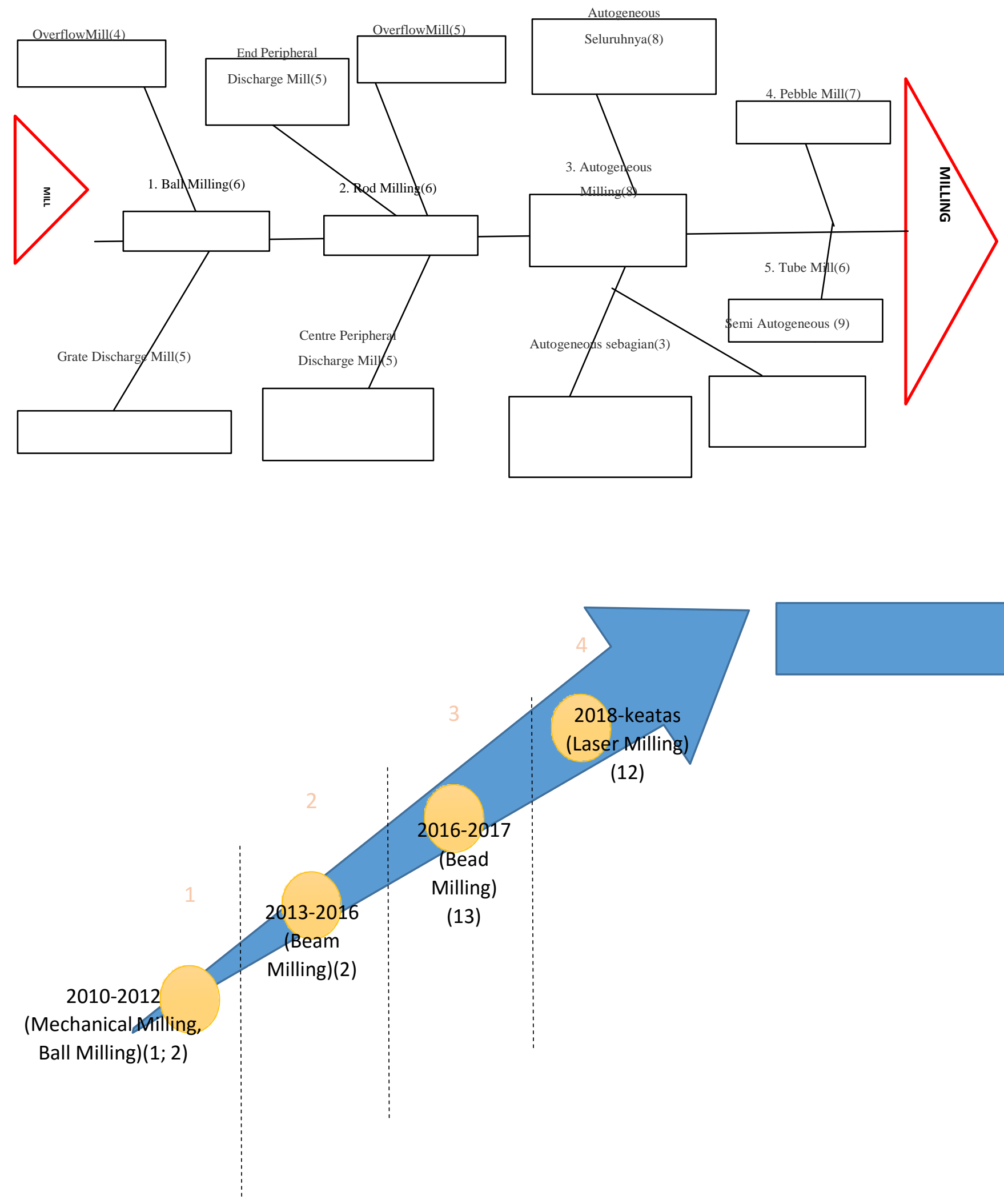


\section{PEMBAHASAN}

CNC mill merupakan salah satu mesin yang digunakan dalam proses milling. Mesin ini digunakan untuk mengerjakan satu jenis penyayatan dengan produktivitas/duplikasi yang sangat tinggi. CNC memiliki tenaga yang relatif besar sehingga menjadikan mesin ini banyak digunakan pada perusahaan manufaktur. Pada mesin ini dilengkapi dengan pengendali CNC untuk meningkatkan produktivitas dan fleksibilitas ${ }^{(15)}$. Dengan menggunakan alat kendali mesin ini waktu produksi menjadi lebih cepat dan hasilnya pun lebih bervariasi. Kelebihan lainnya pada mesin ini memiliki ketelitian yang tinggi. Namunbeberapa perusahaan tidak dapat menggunakan mesin ini karena keterbatasan anggaran sehingga mereka lebih memilih mesin manual. Kekurangan pada mesin ini yakni dalam prosesnya kaku dan kekuatan penyayatannya yang rendah $^{(20)}$.

Adapun prinsip kerja NC/CNC adalah :

1. Program $\mathrm{CNC}$ dibuat dengan cara diketik langsung pada mesin $\mathrm{CNC}$ menggunakan perangkat lunak pemograman $\mathrm{CNC}$.

2. Prinsip kerja ini dikenal dengan G-Code yang kemudian dikirim oleh prosesor pada mesin CNC yang dapat menggerakkan perkakas melalui pengaturan motor servo pada proses permesinan untuk mendapatkan produk sesuai program.

Kebanyakan mesin penggilingan $\mathrm{CNC}^{(42)}$ (juga disebut pusat permesinan) adalah mesin penggilingan vertikal ${ }^{(43)}$ yang dikendalikan komputer dengan kemampuan untuk memindahkan poros secara vertikal ${ }^{(44)}$ sepanjang sumbu Z. Tingkat kebebasan ekstra ini memungkinkan penggunaannya dalam diesinking, aplikasi ukiran,dan permukaan 2.5D seperti patung relief . Ketika dikombinasikan dengan penggunaan alat ${ }^{(45)}$ berbentuk kerucut atau pemotong hidung bola, itu juga secara signifikan meningkatkan presisi penggilingan ${ }^{(46)}$ tanpa mempengaruhi kecepatan, memberikan alternatif yang hemat biaya untuk sebagian besar pekerjaan ukiran tangan permukaan datar.

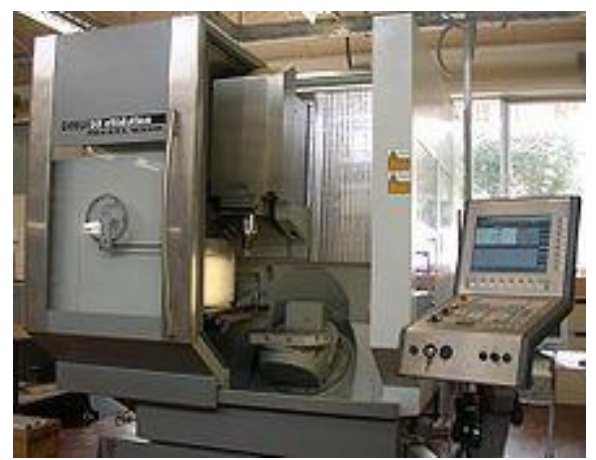

Gambar 2. Pusat permesinan lima sumbu dengan meja putar dan antar muka komputer (23)

Mesin CNC bisa ada di hampir semua bentuk mesin manual ${ }^{(47)}$, seperti pabrik horizontal. Mesin milling CNC paling canggih, mesin multiasaks ${ }^{(48)}$, menambahkan dua kapak tambahan di samping tiga sumbu normal (XYZ). Mesin penggilingan horizontal juga memiliki sumbu $\mathrm{C}$ atau $\mathrm{Q}$, memungkinkan benda 
kerja yang dipasang secara horizontal untuk diputar, pada dasarnya memungkinkan pemintalan yang asimetrisdan eksentrik. Sumbu kelima (sumbu B) mengontrol kemiringan alat itu sendiri. Ketika semua sumbu ini digunakan bersama dengan satu sama lain, geometri yang sangat rumit, bahkan geometri organik seperti kepala manusia dapat dibuat dengan relatif mudah dengan mesin-mesin ini. Tetapi keterampilan untuk memprogram geometri semacam itu berada di luar jangkauan sebagian besar operator. Oleh karena itu, mesin penggilingan 5-sumbu praktis selalu diprogram dengan CAM.

Sistem operasi mesin tersebut adalah sistem loop tertutup dan berfungsi sebagai umpan balik. Mesin-mesin ini telah dikembangkan dari mesin NC (NUMERIC CONTROL) dasar. Suatu bentuk mesin NC yang terkomputerisasi dikenal sebagai mesin CNC.Serangkaian instruksi (disebut program) digunakan untuk memandu mesin untuk operasi yang diinginkan. Beberapa kode yang sangat umum digunakan, yang digunakan dalam program ini adalah:

G00 - traverse cepat

G01 - interpolasi alat secara linier.

G21 - dimensi dalam satuan metrik.

M03 / M04 - mulai spindel (searahjarum jam/berlawanan arah jarum jam).

T01 M06 - perubahan alat otomatis kealat 1

M30 - akhir program.

Berbagai kode lain juga digunakan. Sebuah mesin CNC dioperasikan oleh operator tunggal yang disebut programmer. Mesin ini mampu melakukan berbagai operasi secara otomatis dan ekonomis.Dengan penurunan harga komputer dan perangkat lunak open source $\mathrm{CNC}$, harga masuk mesin $\mathrm{CNC}$ anjlok.

Pada mesin Ball Mill proses kerja pada mesin ini masih dikerjakan secara manual. Pada umumnya mesin ini dimiliki oleh perusahaan-perusahaan manufaktur dikarenakan anggaran biaya lebih efisien dibanding $\mathrm{CNC}^{(18)}$. Ball Mill terbuat dari logam yang mempunyai karakteristik keras sekaligus tangguh (tidak mudah pecah) dan tahan korosi untuk menanggung beban dan lingkungan selama proses penggilingan materi ${ }^{(18)}$. Namun, dalam proses pengerjaannya membutuhkan waktu yang cukup lama dibandingkan menggunakan CNC dan bentuk dari hasilnya pun kurang bervariasi. Prinsip kerja mesin milling tersebut adalah dengan memotong atau menyayat permukaan benda kerja dengan pisau bermata banyak yang berputar baik secara vertikal maupun horizontal dimana benda kerja ini dijepit pada ragum dan meja mesin digerakkan sejalan sumbu $\mathrm{X}, \mathrm{Y}, \mathrm{Z}^{(20)}$.

Ball milling ini memiliki beberapa keunggulan dibandingkan dengan sistem yang lain ${ }^{(49)}$, biaya yang dikeluarkan menggunakan mesin ini rendah, cocok untuk melakukan proses penggilingan dalam jumlah yang banyak dan berkelanjutan. Demikian pula cocok untuk membuka serta menutup sirkuit pada penggilingan dan berlaku untuk semua jenis kekerasan suatu bahan ${ }^{(50)}$. 
Ball milling ini juga biasa digunakan untuk menggiling ${ }^{(51)}$ material seperti batu bara, pigmen dan feldspar untuk tembikar. Penggilingan ini dapat dilakukan dalam keadaan basah maupun kering ${ }^{(52 ; 53)}$ namun dalam proses pembentukannya dilakukan dengan kecepatan yang rendah. Ball milling ini sudah terbukti efektif ${ }^{(54)}$ dalam memproduksi material amorf.

Hasil milling adalah material yang dihasilkan setelah mengalami perlakuan pada mesin milling yang meliputi pengurangan ukuran-ukuran karena pemakanan yang dilakukan oleh pahat. Hasil milling dapat dikatakan baik atau buruk didasarkan oleh dua faktor, yaitu ketepatan pada ukuran-ukurannya (kepresisian) dan tingkat kualitas permukaan yang dihasilkan. Melihat kedua faktor tersebut maka hasil milling dapat dikatakan baik apabila material ${ }^{(17 ; 28 ; 29 ; 45 ; 55 ; 56)}$ yang dihasilkan sesuai dengan ukuran $^{(7 ; 57)}$ yang diinginkan dan permukaan material mempunyai tingkat kekasaran yang rendah (halus).

Berikut faktor yang mempengaruhi tingkat kekerasan hasil milling :

1. Bahan

Bahan berkaitan dengan sifat-sifat yang dimiliki oleh bahan itu sendiri, seperti : sifat keras, lunak, liat, dan lain-lain.

2. Pahat

Sifat-sifat bahan yang harus ada untuk setiap bahan pahat adalah mempu menahan pada pelunakan yang tinggi, harus lebih keras dari benda kerja dan mempunyai ketahanan yang tinggi untuk mengatasi retakan.

3. Pendingin

Pendingin adalah suatu proses untuk mendinginkan panas yang terjadi akibat dua benda saling bergesekan, syarat-syarat pendingin sendiri meliputi : a) Mempunyai daya dingin yang baik

b)Mempunyai daya lumas yang baik

c)Mempunyai sifat netral terhadap benda kerja yakni menimbulkan karat ( korosi )

d)Tidak menganggu kesehatan

e)Tidak cepat memuai.

4. Tebal Pemakanan

Pemakanan adalah jarak yang ditempuh oleh pahat penyayat ketika langkah pemakanan berlangsung. Ketebalan pemakanan merupakan besaran yang menunjukan seberapa tebal penyayatan saat melakukan pemakanan.

5. Kecepatan Potong

Kecepatan potong merupakan kecepatan pemakanan pahat dalam satuan $\mathrm{m} / \mathrm{menit}$ atau $\mathrm{ft} / \mathrm{menit}^{\left({ }^{(2)}\right)}$

Kekasaran permukaan merupakan salah satu penyimpangan yang disebabkan oleh kondisi potongan dari proses permesinan. Oleh karena itu, untuk memperoleh produk ${ }^{(43 ; 57-59)}$ bermutu berupa tingkat kepresisian yang tinggi serta kekasaran permukaan yang baik, perlu didukung oleh proses permesinan yang tepat.

Rod mill sangat mirip dengan ball mill, tetapi pada rod mill menggunakan batang panjang yang digunakan untuk menggiling material ${ }^{(9-11 ; 13 ; 54 ; 60-66)}$. Batang tersebut menggiling material $^{(3 ; 67 ; 68)}$ yang terdapat dalam penggilingan. Untuk mencegah terjadinya pengencangan terhadap muatan batang tersebut maka rasio 
diameter yang digunakan yakni 1,4 hingga 1,6. Rod Mills menerima material dengan ukuran kira-kira hingga $50 \mathrm{~mm}$ (2 inci) dan menghasilkan produk pada ukuran 3000 sampai $270 \mathrm{~mm}$ (-4 hingga -35 mesh).

Dari 3 jenis rod mill, yakni overflow ${ }^{(69)}$, end peripheral discharge, dan centre perifer, yang paling umum digunakan yakni overflow mill. Penggilingan dengan bahan basah pada rod mill biasanya digunakan dalam industry pengolahan mineral. Penggilingan kering itu digunakan di beberapa industry, namun penggilingan ini sebaiknya dihindari kecuali jika benar-benar diperlukan karena dapat memunculkan beberapa masalah. Rod mill ${ }^{(9 ;}{ }^{70-72)}$ beroperasi dengan kecepatan yang lebih rendah dibandingkan ball mill, karena batangnya menggulung dan tidak mengalir.

Pada penggilingan dengan material yang sama, Rod mill menggunakan baja yang lebih sedikit dibandingkan ball mill ${ }^{(9 ; 73-78)}$ karena kecepatannya lebih rendah dibandingkan ball mill dan proses penggilingan yang lebih baik. Batang penggiling pada Rod mill harus dijaga dalam kondisi kerja yang baik, dan batang yang tidak bagus kinerjanya harus dilepas dari penggiling. Rod mill membutuhkan perhatian besar dari operator. Sangat penting sekali memastikan batang penggiling dalam posisi sejajar satu sama lain. Jika batang penggiling tidak sejajar, proses penggilingan tidak terjadi dan yang lebih penting batang tidak pada posisi yang seharusnya dan menjadi kusut. Panjang batang maksimum yakni $6,1 \mathrm{~m} .^{(4)}$
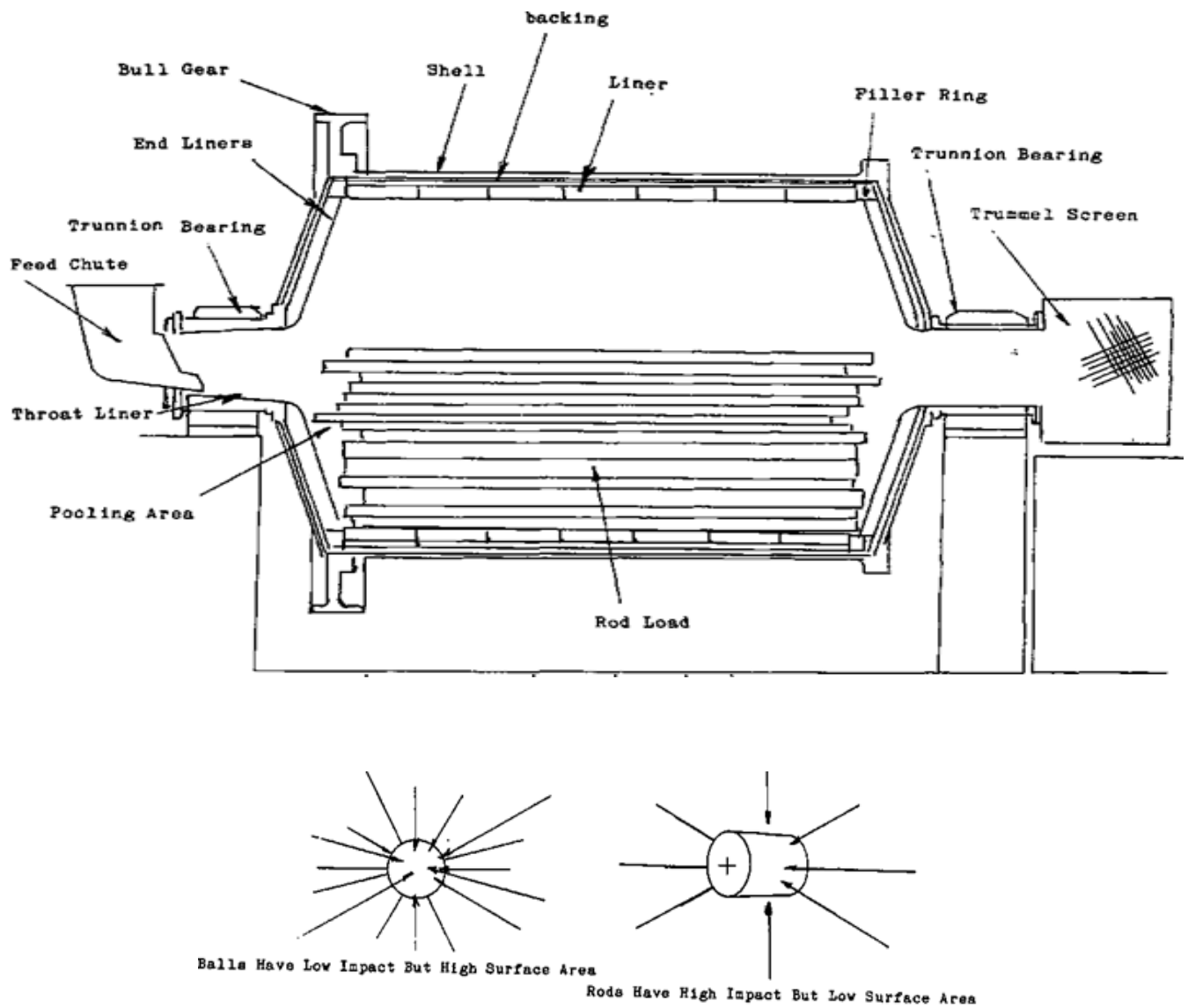


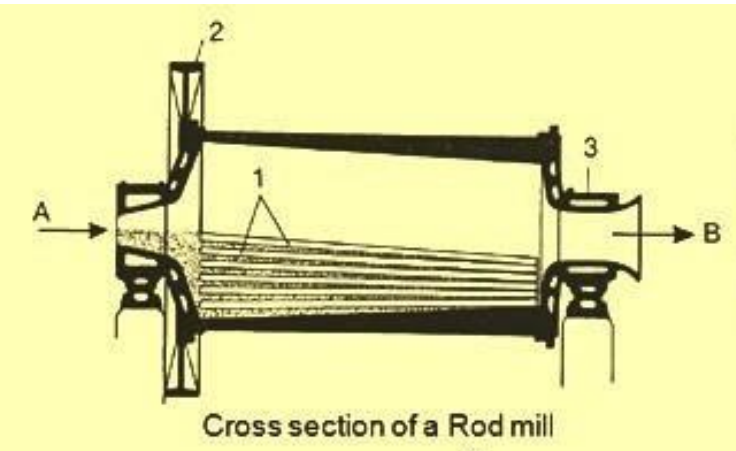

2

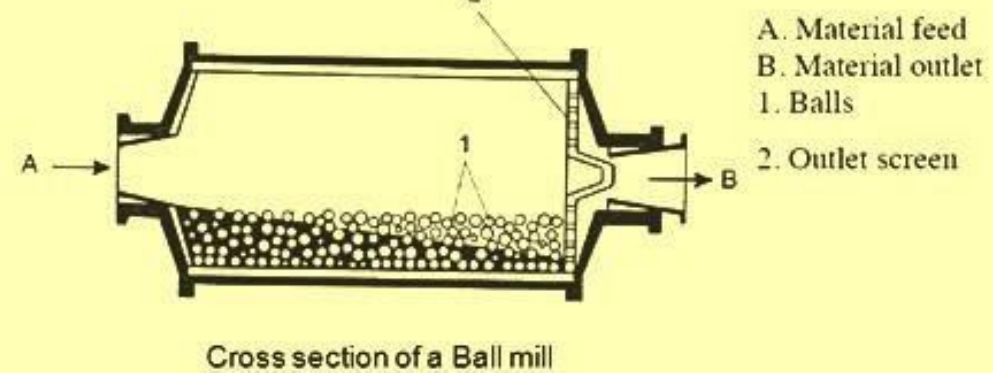

Gambar 4. Mesin Rod Mill dan Ball Mill (4)

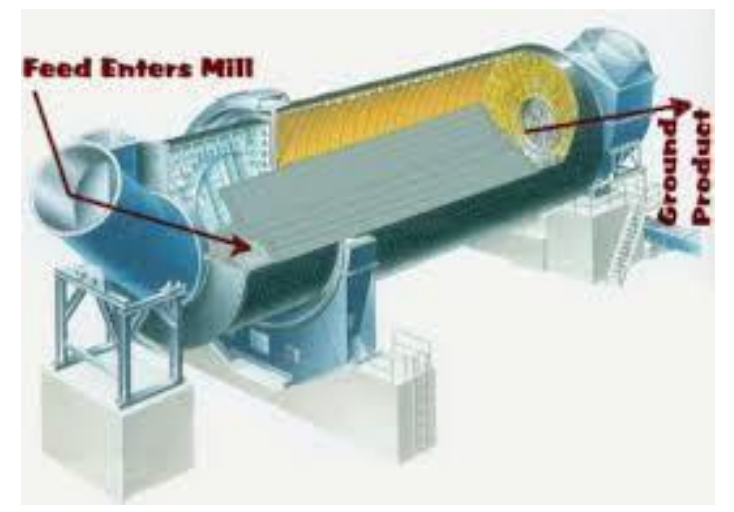

Gambar 5. Mesin Rod Mill (79)

Rod mill normalnya membawa 35 hingga $65 \%$ muatan batangan berdasarkan volume ${ }^{(80 ; 81)}$. Batas pada tingkat muatan adalah (1) menjaga trunnion ujung material terbuka sehingga material yang akan digiling akan masuk ke penggilingan, dan (2) menjaga muatan batang penggiling tetap rendah sehingga batang tidak akan bekerja dengan cara masuk ke bukaan pembuangan di mana mereka dapat menyebabkan kekusutan batang.

Autogeneous $^{(82)}$ atau autogenik mill disebut juga penggiling yang melalukan penggilingan material sendiri: drum yang berputar melemparkan batuan bijih yang lebih besar dalam gerakan kaskade yang menyebabkan pecahnya dampak batuan yang lebih besar dan penggilingan kompresif partikel yang lebih halus. Hal ini serupa dalam operasi untuk SAG mill seperti yang dijelaskan di bawah tetapi tidak menggunakan bola baja pada penggiling. 
Autogenous mill inijuga dikenal dengan sebutan ROM atau "Run Of Mine" grinding.

\section{Mesin penggilingan vertikal manual}

Komponen-komponen mesin penggilingan di atas dapat diorientasikan secara vertical atau horizontal, menciptakan dua bentuk mesin penggilingan yang sangat berbeda. Mesin penggilingan horizontal menggunakan pemotong yang dipasang pada poros horizontal, yang disebut punjung, di atas benda kerja. Untuk alas an ini, penggilingan ${ }^{(6 ; 10 ; 11 ; 51 ; 64 ; 77 ; 78 ; 83-85)}$ horizontal kadangkadang disebut sebagai penggilingan pancang. Arbor didukung di satu sisi oleh overarming, yang terhubung kekolom, dan di sisi lain oleh spindel. Spindle digerakkan oleh motor dan karenanya memutar punjung. Selama penggilingan, pemotong berputar sepanjang sumbu horizontal dan sisi pemotong menghilangkan material ${ }^{(32 ; 41 ; 50 ; 67 ; 68 ; 86-96)}$ dari benda kerja. Sebuah mesin penggilingan vertikal, di sisi lain, mengarahkan pemotong secara vertikal. Pemotongnya diamankan di dalam potongan yang disebut collet ${ }^{(97 ; 98)}$, yang kemudian ditempelkan ke spindel yang berorientasi vertikal. Spindel terletak di dalam kepala penggilingan, yang dilekatkan pada kolom.Operasi penggilingan yang dilakukan pada mesin penggilingan vertical menghilangkan material dengan menggunakan bagian bawah dan sisi pemotong.

Mesin penggilingan juga dapat diklasifikasikan berdasarkan jenis kontrol yang digunakan ${ }^{(6 ; 99-101)}$. Sebuah mesin penggilingan manual membutuhkan operator untuk mengontrol gerakan pemotong selama operasi penggilingan. Operator menyesuaikan posisi pemotong dengan menggunakan engkol tangan yang menggerakkan meja, sadel, dan lutut. Mesin penggilingan juga dapat dikendalikan komputer ${ }^{(60)}$, dalam hal ini mereka disebut sebagai mesin penggilingan numeric komputer (CNC) milling machine. Mesin penggilingan CNC memindahkan benda kerja dan pemotong berdasarkan perintah yang terprogram dan menawarkan presisi yang sangat tinggi. Program yang ditulis sering disebut G-codes atau NC-codes. Banyak mesin penggilingan CNC juga mengandung sumbu gerak lain selain gerakan XYZ standar. Sudut spindle dan cutter dapat diubah, memungkinkan bentuk yang lebih rumit untuk digiling.

\section{KESIMPULAN}

Milling merupakan proses penguraian material yang menghasilkan bentukan bidang datar yang biasanya menggunakan proses dengan menggunakan bantuan mesin. Prinsip kerja mesin milling adalah dengan memotong atau menyayat permukaan benda kerja dengan pisau bermata banyak yang berputar baik secara vertikal maupun horizontal dimana benda kerja ini dijepit pada ragum dan meja mesin digerakkan sejalan sumbu $\mathrm{X}, \mathrm{Y}, \mathrm{Z}$. 
Referensi

1. Choi Y, Baik NI. 2012. Structure analysis and magnetic properties of nano-sized $\mathrm{Nb}(\mathrm{x}) \mathrm{Ni}(\mathrm{y}) \mathrm{Zn} 1-\mathrm{x}-\mathrm{yFe} 2 \mathrm{O} 4$ powders formed by combustion synthesis and mechanical milling. Journal of nanoscience and nanotechnology 12:1667-9

2. Jamali M, Gerhardt I, Rezai M, Frenner K, Fedder H, Wrachtrup J. 2014. Microscopic diamond solid-immersion-lenses fabricated around single defect centers by focused ion beam milling. The Review of scientific instruments 85:123703

3. Leung K. 1988. An energy based, ore specific model for autogenous and semiautogenous grinding mills.

4. 2017. Ball Mills vs Rod Mills. www.911metallurgist.com/ball-mills-vs-rod-mills/

5. 2015. Overflow vs Grate Discharge Ball or Mill - Why Retrofit. https://www.911metallurgist.com/blog/overflow-vs-grate-discharge-ball-mills

6. Withington WH. 1938. Ball, Rod and Tube Mills. Industrial \& Engineering Chemistry 30:897-904

7. Fischer EK. 1941. Dispersion of Pigments by Ball and Pebble Mills. Industrial \& Engineering Chemistry 33:1465-71

8. Burgess D. 2012. A Method of Calculating Autogenous/Semi-Autogenous Grinding Mill Specific Energies Using a Combination of Bond Work Indices and Julius Kruttschnitt Parameters, then Applying Eficiency Factors. In 11th Mill Operators' Conference

9. Morrell S. 2004. Predicting the specific energy of autogenous and semi-autogenous mills from small diameter drill core samples. Minerals Engineering 17:447-51

10. Verma GC, Pandey PM. 2018. Machining forces in ultrasonic-vibration assisted end milling. Ultrasonics

11. Caron V, Willart JF, Lefort R, Derollez P, Danede F, Descamps M. 2011. Solid state amorphization kinetic of alpha lactose upon mechanical milling. Carbohydr Res 346:2622-8

12. Nakamura N, Sugano N, Sakai T, Nakahara I. 2018. Does Robotic Milling For Stem Implantation in Cementless THA Result in Improved Outcomes Scores or Survivorship Compared with Hand Rasping? Results of a Randomized Trial at 10 Years. Clinical orthopaedics and related research

13. Anand C, Yamaguchi Y, Liu Z, Ibe S, Elangovan SP, et al. 2016. Pioneering In Situ Recrystallization during Bead Milling: A Top-down Approach to Prepare Zeolite A Nanocrystals. Sci Rep 6:29210

14. Chen L, Ding X, He Z, Fan S, Kunnath KT, et al. 2018. Surface engineered excipients: II. Simultaneous milling and dry coating for preparation of fine-grade microcrystalline cellulose with enhanced properties. International journal of pharmaceutics $546: 125-36$

15. Caballero ES, Cuevas FG, Ternero F, Astacio R, Montes JM, Cintas J. 2018. In Situ Synthesis of Al-Based MMCs Reinforced with AlN by Mechanical Alloying under $\mathrm{NH}(3)$ Gas. Materials 11

16. James AE, Umamaheswari B, Shanthana Lakshmi CB. 2018. Comparative Evaluation of Marginal Accuracy of Metal Copings Fabricated using Direct Metal Laser Sintering, Computer-Aided Milling, Ringless Casting, and Traditional Casting Techniques: An In vitro Study. Contemporary clinical dentistry 9:421-6

17. Alfano KM, Chakraborty S, Tarasev M. 2016. Differences in bead-milling-induced hemolysis of red blood cells due to shape and size of oscillating bead. Biomed Mater Eng 
18. Ganive Pangesthi Aji HP. 2012. Pengaruh Milling Time Terhadap Pembentukan Fasa $\gamma$-MgAl Hasil Mechanical Alloying JURNAL TEKNIK POMITS Vol. 1: 1-5

19. Ohkuma K, Kameda T, Terada K. 2018. Five-axis laser milling system that realizes more accurate zirconia CAD/CAM crowns by direct milling from fully sintered blocks. Dental materials journal

20. Ernawati Jassin IY. 2014. EFEKTIFITAS KINERJA MESIN BALL MILL PADA FORMULA COKELAT BERDASARKAN PERBANDINGAN SUHU DAN RPM (ROTATION PER MINUTE) Jurnal Galung Tropika 3:116-26

21. El-Sayed TH, Aboelnaga A, El-Atawy MA, Hagar M. 2018. Ball Milling Promoted N-Heterocycles Synthesis. Molecules 23

22. Dabrowski M, Gorski J. 2018. Influence of the Milling Tool Setup on Occupational Safety in Furniture Making. International journal of occupational safety and ergonomics : JOSE:1-30

23. Hari Yanuar AS, Ach. Kusairi 2014. PENGARUH VARIASI KECEPATAN POTONG DAN KEDALAMAN PEMAKANAN TERHADAP KEKASARAN PERMUKAAN DENGAN BERBAGAI MEDIA PENDINGIN PADA PROSES FRAIS KONVENSIONAL. Jurnal Ilmiah Teknik Mesin Unlam 3:27-33

24. Caggiano A, Improta I, Nele L. 2018. Characterization of a New Dry Drill-Milling Process of Carbon Fibre Reinforced Polymer Laminates. Materials 11

25. Ayuba EO, Bolu CA, John TM, Abioye AA. 2018. Dataset showing steel cold rolling process parameters for a 6-high cold rolling mill in Nigeria. Data in brief 18:891-901

26. Bozdemir M. 2018. Prediction of Surface Roughness considering Cutting Parameters and Humidity Condition in End Milling of Polyamide Materials. Computational intelligence and neuroscience 2018:5850432

27. Chen W, Liang Y, Hou X, Zhang J, Ding H, et al. 2018. Mechanical Grinding Preparation and Characterization of $\mathrm{TiO}(2)$-Coated Wollastonite Composite Pigments. Materials 11

28. Ali A, Hantanasirisakul K, Abdala A, Urbankowski P, Zhao MQ, et al. 2018. Effect of Synthesis on Performance of MXene/Iron Oxide Anode Material for Lithium-Ion Batteries. Langmuir : the ACS journal of surfaces and colloids

29. Baldo MP, Zaniqueli DA, Mill JG. 2018. Commentary: Peripheral and Central Aortic Pressure, Wave-Derived Reflection Parameters, Local and Regional Arterial Stiffness and Structural Parameters in Children and Adolescents: Impact of Body Mass Index Variations. High blood pressure \& cardiovascular prevention : the official journal of the Italian Society of Hypertension

30. Brassel J, Rohrssen F, Failing K, Wehrend A. 2018. Automated oestrus detection using multimetric behaviour recognition in seasonal-calving dairy cattle on pasture. New Zealand veterinary journal 66:243-7

31. Brook BW, Sleightholme SR, Campbell CR, Buettel JC. 2018. Deficiencies in estimating the extinction date of the thylacine with mixed certainty data. Conservation biology: the journal of the Society for Conservation Biology

32. Sanjaya H, Zainul R. 2018. Synthesis and Electrical Properties of ZnO-ITO and AlITO thin Film by Spin Coating Technique Through Sol Gel Process.

33. Balaz M. 2018. Ball milling of eggshell waste as a green and sustainable approach: A review. Advances in colloid and interface science 256:256-75

34. Santos DFM, Soares O, Figueiredo JL, Pereira MFR. 2018. Effect of ball milling on the catalytic activity of cryptomelane for VOC oxidation. Environmental technology:1-14

35. Wang W, Yu H, Liu Y, Jiang X, Gao B. 2018. Trueness analysis of zirconia crowns fabricated with 3-dimensional printing. The Journal of prosthetic dentistry 
36. Ohara Y, Hinokimoto A, Chen W, Kitao T, Nishiyama Y, et al. 2018. Formation of coordination polymer glass by mechanical milling: dependence on metal ions and molecular doping for $\mathrm{H}(+)$ conductivity. Chemical communications 54:6859-62

37. Sundum T, Szecsenyi KM, Kaewtatip K. 2018. Preparation and characterization of thermoplastic starch composites with fly ash modified by planetary ball milling. Carbohydrate polymers 191:198-204

38. Adelhelm P, Medenbach L, Escher I, Zedler L, Dietzek B, et al. 2018. Sulfur Spillover on carbon materials and possible impacts on metal-sulfur batteries. Angewandte Chemie

39. Bartos C, Pallagi E, Szabo-Revesz P, Ambrus R, Katona G, et al. 2018. Formulation of levodopa containing dry powder for nasal delivery applying the quality-by-design approach. European journal of pharmaceutical sciences : official journal of the European Federation for Pharmaceutical Sciences 123:475-83

40. Bartos C, Jojart-Laczkovich O, Katona G, Budai-Szucs M, Ambrus R, et al. 2018. Optimization of a combined wet milling process in order to produce poly(vinyl alcohol) stabilized nanosuspension. Drug design, development and therapy 12:156780

41. Sanjaya H, Zainul R. 2018. Characterization of napa soil and adsorption of $\mathrm{Pb}$ (II) from aqueous solutions using on column method.

42. Albertin E, Sinatora A. 2001. Effect of carbide fraction and matrix microstructure on the wear of cast iron balls tested in a laboratory ball mill. Wear 250:492-501

43. Anhar A, Sumarmin R, Zainul R. 2018. Measurement of Glycemic Index of West Sumatera Local Rice Genotypes for Healthy Food Selection.

44. Austin L, Bagga P, Celik M. 1981. Breakage properties of some materials in a laboratory ball mill. Powder Technology 28:235-43

45. Basset D, Matteazzi P, Miani F. 1993. Designing a high energy ball-mill for synthesis of nanophase materials in large quantities. Materials Science and Engineering: A 168:149-52

46. Bergersen O, Haarstad K. 2014. Treating landfill gas hydrogen sulphide with mineral wool waste (MWW) and rod mill waste (RMW). Waste management 34:141-7

47. Calka A, Radlinski A. 1991. Universal high performance ball-milling device and its application for mechanical alloying. Materials Science and Engineering: A 134:13503

48. Agre J, Elsley G, McFarlane D, Cheng J, Gunn B. Holonic control of a water cooling system for a steel rod mill. Proc. Computer Integrated Manufacturing and Automation Technology, 1994., Proceedings of the Fourth International Conference on, 1994:134-41: IEEE

49. Chen X, Yang J, Li S, Li Q. 2009. Disturbance observer based multi-variable control of ball mill grinding circuits. Journal of Process Control 19:1205-13

50. Mawardi Mawardi EM, Soleh Kosela, Widayanti Wibowo, Rahadian Zainul. 2015. Study of $\mathrm{Pb}(\mathrm{II})$ biosorption from aqueous solution using immobilized Spirogyra subsalsa biomass. Journal of Chemical and Pharmaceutical Research:715-22

51. Cleary P. 1998. Predicting charge motion, power draw, segregation and wear in ball mills using discrete element methods. Minerals Engineering 11:1061-80

52. El-Eskandarany MS, Aoki K, Suzuki K. 1991. Difference between mechanical alloying and mechanical disordering in the amorphization reaction of Al50Ta50 in a rod mill. Journal of alloys and compounds 177:229-44

53. El-Eskandarany MS, Sumiyama K, Aoki K, Suzuki K. Reactive ball mill for solid state synthesis of metal nitrides powders. Proc. Materials Science Forum, 1992, 88:801-8: Trans Tech Publ 
54. Deng S, Zhang J, Ye L. 2009. Halloysite-epoxy nanocomposites with improved particle dispersion through ball mill homogenisation and chemical treatments. Composites Science and Technology 69:2497-505

55. Narayanan SS. 1985. Development of a laboratory single particle breakage technique and its application to ball mill modelling and scale-up.

56. Mishra B, Rajamani RK. 1992. The discrete element method for the simulation of ball mills. Applied Mathematical Modelling 16:598-604

57. Fadjria N, Zainul R. 2018. ISOLATION AND MOLECULAR IDENTIFICATION OF FRESHWATER MICROALGAE IN MANINJAU LAKE WEST SUMATERA.

58. Zainul R, Oktavia B, Dewata I. 2018. Studi Dinamika Molekular dan Kinetika Reaksi pada Pembelahan Molekul Air untuk Produksi Gas Hidrogen.

59. Zainul R, Nurakhbari D, Salim M. 2018. Optimization of Spirulina Platensis Culture for Antioxidant Production.

60. Kelsall D, Reid K, Restarick C. 1968. Continuous grinding in a small wet ball mill Part I. A study of the influence of ball diameter. Powder Technology 1:291-300

61. Stanley G. 1974. Mechanisms in the autogenous mill and their mathematical representation. Journal of the Southern African Institute of Mining and Metallurgy 75:77-98

62. Vickers G, Quan K. 1989. Ball-mills versus end-mills for curved surface machining. Journal of Engineering for Industry 111:22-6

63. Rajamani RK, Herbst JA. 1991. Optimal control of a ball mill grinding circuit-I. Grinding circuit modeling and dynamic simulation. Chemical Engineering Science 46:861-70

64. Tamaki S, Hisamatsu M, Teranishi K, Adachi T, Yamada T. 1998. Structural change of maize starch granules by ball-mill treatment. Starch-Stärke 50:342-8

65. Ramasamy M, Narayanan S, Rao CD. 2005. Control of ball mill grinding circuit using model predictive control scheme. Journal of Process Control 15:273-83

66. Yasthopi A. 2015. Photoelectrosplitting water for hydrogen production using illumination of indoor lights. Journal of Chemical and Pharmaceutical Research 7:246-56

67. Kurniawati D, Lestari I, Harmiwati, Sy S, Chaidir Z, et al. 2015. Biosorption of Pb (II) from aqueous solutions using column method by lengkeng (Euphoria logan lour) seed and shell. 872-7 pp.

68. Zainul R, Oktavia B, Dewata I, Efendi J. Thermal and Surface Evaluation on The Process of Forming a $\mathrm{Cu} 2 \mathrm{O} / \mathrm{CuO}$ Semiconductor Photocatalyst on a Thin Copper Plate. Proc. IOP Conference Series: Materials Science and Engineering, 2018, 335:012039: IOP Publishing

69. Tuncay KS, Gunbey E, Simsek G, Acar B, Karasen RM. 2015. Comparison of autogeneous and homogeneous nasal dorsal onlay grafts in an experimental design. European archives of oto-rhino-laryngology : official journal of the European Federation of Oto-Rhino-Laryngological Societies 272:619-25

70. Mankosa M, Adel G, Yoon R. 1986. Effect of media size in stirred ball mill grinding of coal. Powder technology 49:75-82

71. McFarlane D, Marett B, Elsley G, Jarvis D. Application of holonic methodologies to problem diagnosis in a steel rod mill. Proc. Systems, Man and Cybernetics, 1995. Intelligent Systems for the 21st Century., IEEE International Conference on, 1995, 1:940-5: IEEE

72. Mio H, Kano J, Saito F. 2004. Scale-up method of planetary ball mill. Chemical engineering science 59:5909-16

73. 1895. Rod-mill reel. Google Patents 
74. Rowland C. 1982. Selection of rod mills, ball mills, pebble mills and regrind mills. Design and installation of comminution circuits:393-438

75. Rodríguez B, Rantanen T, Bolm C. 2006. Solvent-Free Asymmetric Organocatalysis in a Ball Mill. Angewandte Chemie 118:7078-80

76. Rodriguez B, Bruckmann A, Bolm C. 2007. A highly efficient asymmetric organocatalytic aldol reaction in a ball mill. Chemistry-A European Journal 13:471022

77. Thorwirth R, Stolle A, Ondruschka B. 2010. Fast copper-, ligand-and solvent-free Sonogashira coupling in a ball mill. Green Chemistry 12:985-91

78. Thorwirth R, Stolle A, Ondruschka B, Wild A, Schubert US. 2011. Fast, ligand-and solvent-free copper-catalyzed click reactions in a ball mill. Chemical Communications 47:4370-2

79. 2012. Rod Mills, How Do They Work? www.mine-engineer.com/mining/rodmill.htm

80. Heyes G, Kelsall D, Stewart P. 1973. Continuous grinding in a small wet rod mill Part I. Comparison with a small ball mill. Powder Technology 7:319-25

81. Herbst J, Fuerstenau D. 1980. Scale-up procedure for continuous grinding mill design using population balance models. International Journal of Mineral Processing 7:1-31

82. Maurice D, Hawk J. 1999. Simultaneous autogenous milling and ferric chloride leaching of chalcopyrite. Hydrometallurgy 51:371-7

83. PA M, Lim K, AD R, Lee Y. 2003. Computational exploration of microstructural evolution in a medium C-Mn steel and applications to rod mill. ISIJ international 43:1421-30

84. Yang J, Li S, Chen X, Li Q. 2010. Disturbance rejection of ball mill grinding circuits using DOB and MPC. Powder Technology 198:219-28

85. Wang Y-F, Chen R-X, Wang K, Zhang B-B, Li Z-B, Xu D-Q. 2012. Fast, solvent-free and hydrogen-bonding-mediated asymmetric Michael addition in a ball mill. Green Chemistry 14:893-5

86. Zainul R, Alif A, Aziz H, Arief S, Dradjad S, Munaf E. 2015. Design of photovoltaic cell with copper oxide electrode by using indoor lights. RESEARCH JOURNAL OF PHARMACEUTICAL BIOLOGICAL AND CHEMICAL SCIENCES 6:353-61

87. Zainul R, Alif A, Aziz H, Arief S. 2015. DISAIN GEOMETRI REAKTOR FOTOSEL CAHAYA RUANG. Jurnal Riset Kimia 8:131

88. Zainul R. 2015. Disain dan Modifikasi Kolektor dan Reflektor Cahaya pada Panel Sel Surya Al/Cu2O-Gel Na2SO4.

89. Zainul R, Alif A, Aziz H, Arief S, Darajat S. 2015. MODIFIKASI DAN KARAKTERISTIK IV SEL FOTOVOLTAIK CU2O/CU-GEL NA2SO4 MELALUI ILUMINASI LAMPU NEON. EKSAKTA 2:50

90. Zainul R, Alif A, Aziz H, Arief S. 2018. Photoelectrosplitting Water Mechanism at Carbon Electrode Surface using Indoor lights.

91. Zainul R. 2018. Effect of Temperature and Particle Motion against the ability of ZnO Semiconductor Photocatalyst in Humic Acid.

92. Zainul R. 2018. Determination of the half-life and the quantum yield of $\mathrm{ZnO}$ semiconductor photocatalyst in humic acid.

93. Zainul R, Dewata I. 2018. Determination of pH-BOD-COD and degradation in batang arau watersheds at Padang city.

94. Yani SR, Zainul R. 2018. Aktivasi Tanah Napa dan Pengaruhnya Terhadap Adsorpsi Ion Timbal (II)/Pb2+.

95. Zainul R. 2018. Design and Modification of Copper Oxide Electrodes for Improving Conversion Coefficient Indoors Lights (PV-Cell) Photocells. 
96. Mawardi M, Deyundha D, Zainul R. Characterization of PCC Cement by Addition of Napa Soil from Subdistrict Sarilamak 50 Kota District as Alternative Additional Material for Semen Padang. Proc. IOP Conference Series: Materials Science and Engineering, 2018, 335:012034: IOP Publishing

97. Gavin FJ. 1947. Tube mill and method of operating same, including discharging. Google Patents

98. Gao M, Forssberg E. 1995. Prediction of product size distributions for a stirred ball mill. Powder Technology 84:101-6

99. Higgins WC. 1994. Weld quality monitoring and control system for a tube mill. Google Patents

100. Hoşten Ç, Özbay C. 1998. A comparison of particle bed breakage and rod mill grinding with regard to mineral liberation and particle shape effects. Minerals engineering 11:871-4

101. Içli B, Christinat N, Tönnemann J, Schüttler C, Scopelliti R, Severin K. 2009. Synthesis of molecular nanostructures by multicomponent condensation reactions in a ball mill. Journal of the American Chemical Society 131:3154-5 


\title{
Teknik Blended : Prinsip dan Dasar-Dasar
}

\author{
Putri Fatimah*1, Rima Jumalia*2, Exsa Rahma Novianti*3, dan Rahadian \\ Zainul*4
}

${ }^{1}$ Chemistry Education, FMIPA, Universitas Negeri Padang, Indonesia

${ }^{2}$ Chemistry Education, FMIPA, Universitas Negeri Padang, Indonesia

${ }^{3}$ Chemistry Education, FMIPA, Universitas Negeri Padang, Indonesia

${ }^{4}$ Physical Chemistry Laboratory, FMIPA, Universitas Negeri Padang, Indonesia

\begin{abstract}
*E-mail : putrifatimah565@gmail.com, rimajumalia97@gmail.com, rahmaeksa@gmail.com, rahadianzmsiphd@yahoo.com.
\end{abstract}

\begin{abstract}
Abstrak. Blending adalah salah satu metode atau proses material dengan cara kerjanya menggabungkan bahan material dalam jumlah yang telah ditentukan. Review ini bertujuan untuk mengulas kembali atau meninjau kembali suatu penelitian yang telah dilakukan orang lain agar diketahui oleh khalayak umum. Metode seperti blending dapat digunakan untuk membuat nano selulosa dari ampas tebu, sistesis chitin/curcumin, dan pembuatan batu bara. Alat yang digunakan dalam teknik blending ini dapat melakukan proses pencampuran resin polimer atau pencampuran lain sesuai kebutahan yang diinginkan. Hal yang harus diperhatikan dalam teknik blending ini adalah bahan atau material yang digunakan untuk membuat produk harus sesuai dengan proporsi yang sudah ditetapkan.
\end{abstract}

Kata kunci : Blending, metode, material, review.

\section{Pendahuluan}

Dewasa ini, perkembangan ilmu pengetahuan berjalan sangat cepat. Salah satunya di bidang Teknik. Suatu material[39] yang tidak terpakai atau tidak digunakan lagi dapat diubah menjadi suatu hal yang bisa digunakan, contohnya pembuatan minyak bumi dan pembuatan nano[39] selulosa dari ampas tebu[26]. Ampas tebu dapat diubah menjadi nano selulosa dengan menggunakan teknik pencampuran atau biasa dikenal dengan Blending[11-15, 26, 45-58].

Blending adalah suatu proses pencampuran untuk mendapatkan produk atau umpan yang memenuhi persyaratan atau spesifikasi yang diperlukan. Dalam proses pembuatan minyak bumi, teknik blending ini sangat dibutuhkan. Beberapa tahapan proses pembuatan minyak bumi adalah destilasi[59-66], cracking[67-74], reforming[75-80], polimerisasi[81-83], treating dan blending.

Pada tahapan blending, dilakukan pencampuran 22 bahan zat aditif yang ditambahkan ke dalam proses pengolahannya. Bahan yang dicampur seperti TEL (Tetra ethyl lead), MTBE (methyl tert-buthyl ether), etanol dan metanol. Penambahan zat aditif ditujukan untuk meningkatkan bilangan oktan pada minyak bumi. Demikian pula halnya pelumas untuk memperoleh kualitas yang terbaik dan bisa juga ditambahkan zat aditif lainnya. Penambahan TEL dapat meningkatkan bilangan oktan namun juga dapat menimbulkan pencemaran.

Metode blending dapat menghasilkan komposit yang homogen selanjutnya, peningkatan nilai densitas dapat dilakukan dengan metode kompaksi berupa padatan untuk meminimalkan 
jarak. Penggunaan metode blending dan kompaksi bertujuan untuk mengetahui pengaruh terhadap morfologi komposit polimer.

Metode blending, selain diterapkan pada pembuatan minyak bumi dan nano selulosa juga dapat diterapkan pada pembuatan kokas, yaitu pencampuran antara batubara coking dengan batubara lignite. Pencampuran ini biasa disebut dengan coal blending[13]. Coal blending adalah pencampuran batubara coking dan non-coking dengan perbandingan tertentu. Hal ini dikarenakan jumlah batubara coking relatif lebih rendah dibandingkan dengan batubara non-coking.

Jadi, blending adalah salah satu teknik atau proses material dimana cara kerjanya dengan menggabungkan atau mencampurkan bahan material dengan jumlah yang telah ditentukan. Teknik ini biasa digunakan dalam mensintesis suatu material tertentu, seperti pembuatan nano selulosa dari ampas tebu[26], sintesis chitin/curcumin[84] dan pembuatan batu bara[85].

\section{Metode}

Metode[86] yang digunakan pada teknik blended ini, yaitu :

a. Isolasi[26] bahan baku

Tujuan dari isolasi bahan baku adalah untuk menghilangkan residu dari bahan baku.

b. Sintesis[87] produk

Hasil isolasi bahan baku diblending dengan bahan-bahan lain yang akan dijadikan produk.

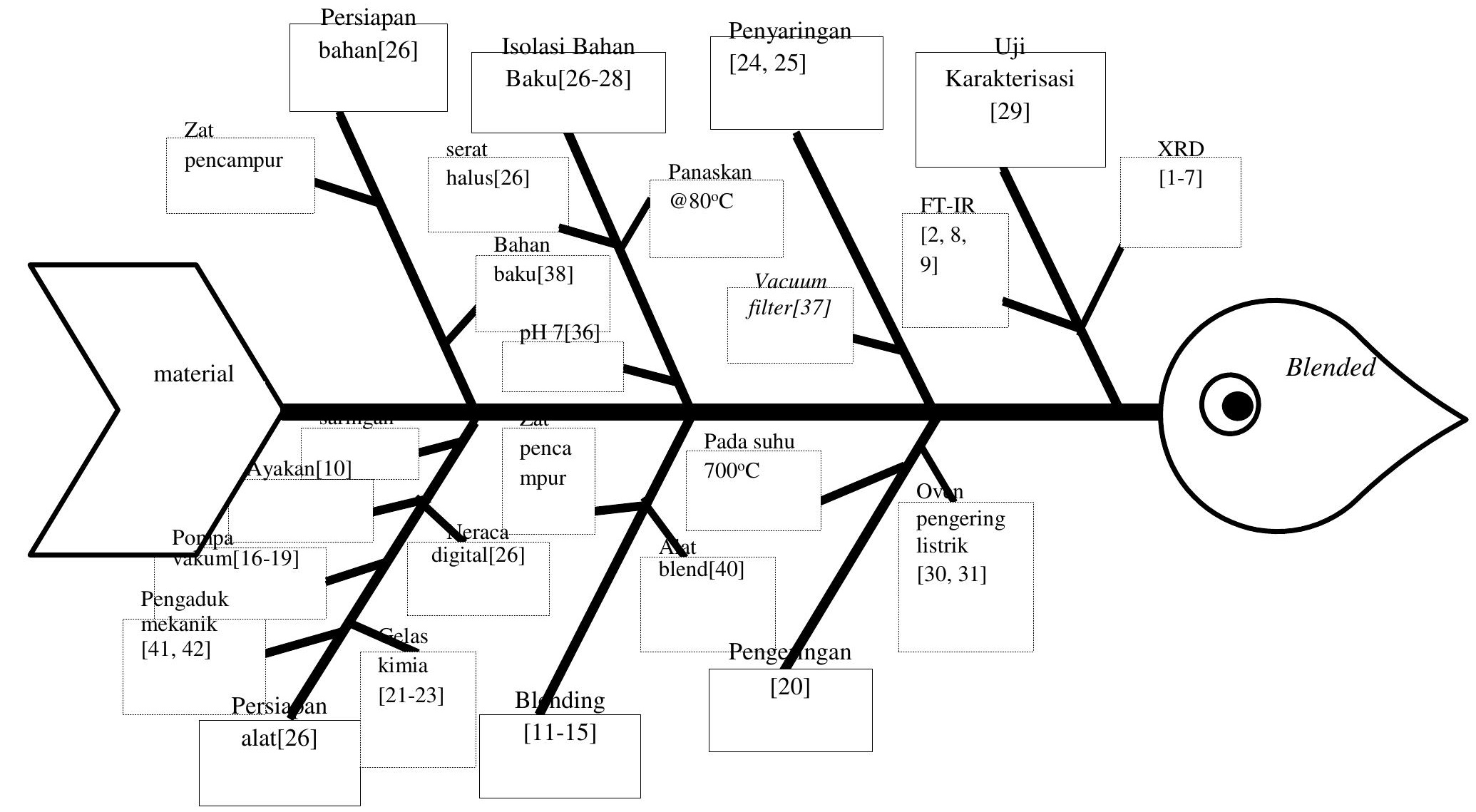

Gambar 1. Fishbone metode blending 
Fishbone[88-92] diatas menunjukkan proses sintesis material dengan menggunakan prinsip dan metode blended. Tahapan yang harus dilakukan yaitu persiapan bahan, persiapan alat, isolasi bahan baku, blending, penyaringan, pengeringan dan uji karakterisasi. Alat yang digunakan diantaranya gelas kimia, ayakan, saringan, neraca digital, pengaduk mekanik dan pompa vakum. Bahan yang digunakan yaitu bahan baku dan zat pencampur. Langkah pertama yaitu isolasi bahan baku, yang bertujuan agar didapatkan bahan baku yang lebih halus. Hal yang harus diperhatikan pada tahap ini yaitu dilakukan pada suhu $80^{\circ} \mathrm{C}$ dan $\mathrm{pH}$ 7. Selanjutnya, dilakukan proses blending atau pencampuran bahan baku yang telah diisolasi dengan zat pencampur lainnya. Proses blending dilakukan dengan menggunakan alat blend (blender). Selanjutnya adalah proses penyaringan dengan menggunakan vacuum filter, yang bertujuan agar didapatkan serat. Kemudian dilakukan pengeringan pada suhu $700^{\circ} \mathrm{C}$ dengan menggunakan oven pengering listrik. Produk yang dihasilkan dapat diuji karakterisasinya dengan

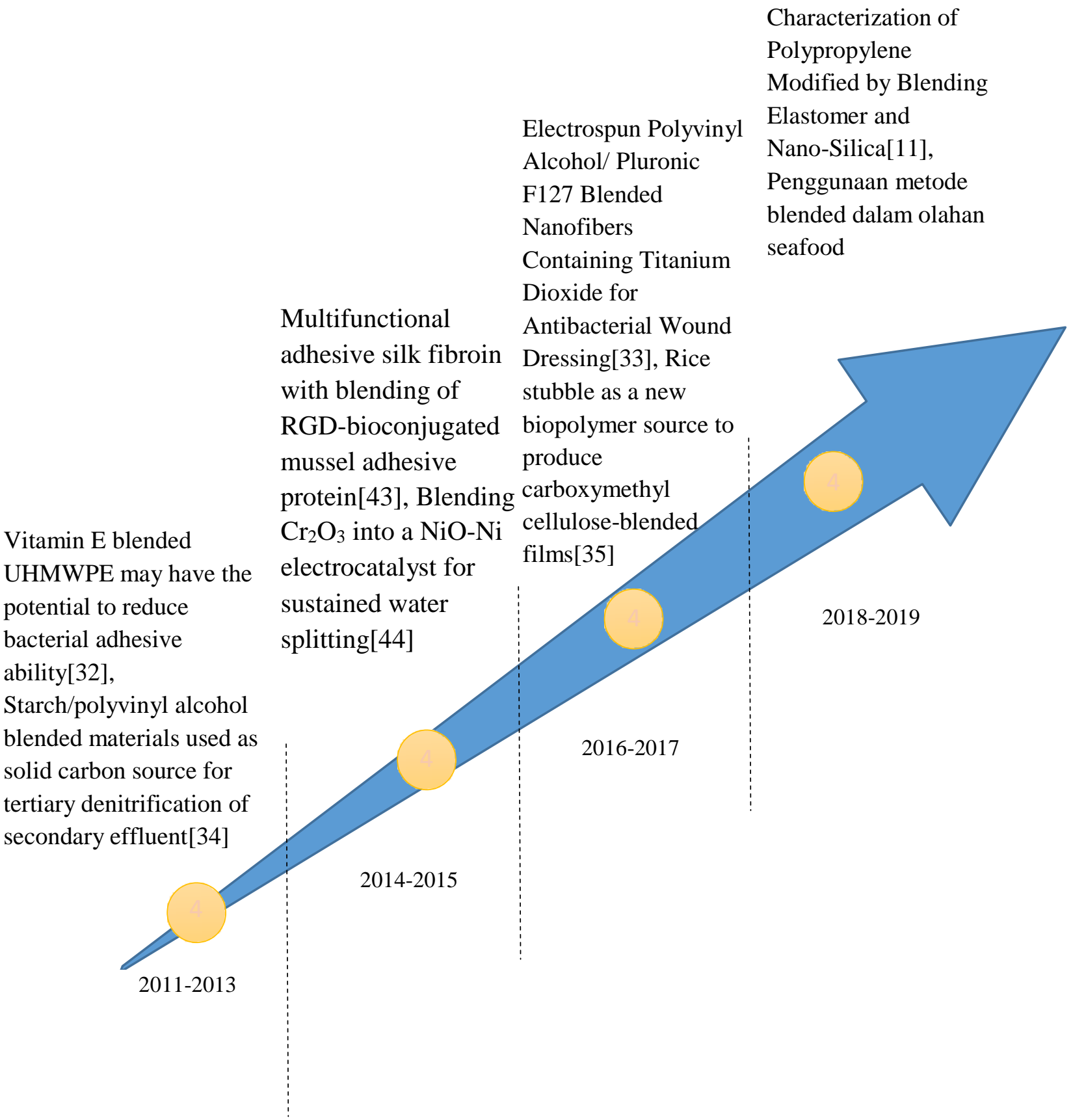

Gambar 2. Roadmap penggunaan metode Blended 
Roadmap[93-100] diatas menunjukkan bahwa metode blended sudah digunakan dalam proses sintesis material. Pada tahun 2011, metode blended digunakan untuk mencampurkan Vitamin E[101] dengan UHMWPE (Ultra high molecular weight polyethylene) yang berfungsi untuk mereduksi kemampuan adhesi bakteri. Pada tahun 2013, metode blended digunakan untuk pencampuran polivinil alkohol. Pada tahun 2014, metode blended digunakan dalam pencampuran $R G D$-bioconjugated untuk mensintesis fibroin sutera. Pada tahun 2015, metode blended digunakan dalam mensintesis elektrokatalis NiO-Ni. Pada tahun 2016, metode blended digunakan dalam pencampuran nanofibers untuk balutan luka antibakteri. Pada tahun 2017, metode blended digunakan dalam campuran jerami padi sebagai sumber biopolimer. Pada tahun 2018, metode blended digunakan dalam karakterisasi modifiksai Polypropylene. Berdasarkan penelitian-penelitian yang telah dilakukan oleh para peneliti, mulai dari taun 2011 hingga tahun 2018, metode blended diperkirakan dapat diaplikasikan pada industri makanan (olahan seafood).

Keterangan :

\section{1}

Vitamin E blended UHMWPE may have the potential to reduce bacterial adhesive ability[32].

2013

Starch/polyvinyl alcohol blended materials used as solid carbon source for tertiary denitrification of secondary effluent[34].

\section{4}

Multifunctional adhesive silk fibroin with blending of RGD-bioconjugated mussel adhesive protein[43].

2015

Blending $\mathrm{Cr}_{2} \mathrm{O}_{3}$ into a NiO-Ni electrocatalyst for sustained water splitting[44].

2016

Electrospun Polyvinyl Alcohol/ Pluronic F127 Blended Nanofibers Containing Titanium Dioxide for Antibacterial Wound Dressing[33].

2017

Rice stubble as a new biopolymer source to produce carboxymethyl cellulose-blended films[35].

\section{8}

Characterization of Polypropylene Modified by Blending Elastomer and Nano-Silica[11]

2019

Penggunaan metode blended dalam olahan seafood. 


\section{Pembahasan}

Teknik blended $[11-15,26,45-58]$ merupakan salah satu teknik yang dapat digunakan dalam proses sintesis material. Prinsip dari blended ini adalah menggabungkan atau mencampurkan bahan-bahan material yang dibutuhkan dalam pembuatan material baru dengan jumlah yang sesuai. Dalam prosesnya, pencampuran bahan-bahan material dapat dengan menggunakan alat dari yang relatif mahal dan dengan cara kerja yang lebih kompleks hingga yang lebih murah dan sederhana. Hal ini tergantung pada produk yang ingin disintesis.

Kualitas produk tergantung kepada kehomogenan dari bahan-bahan penyusunnya. Proses blending dapat dilakukan dalam keadaan basah dan keadaan kering. Bahan-bahan yang memiliki ukuran yang beragam diblending dengan tujuan agar memiliki ukuran yang homogen sehingga mengurangi porositas.

Metode blended, secara garis besarnya memiliki 2 tahapan, yaitu isolasi bahan baku dan sintesis produk dengan menggunakan teknik pencampuran (blended). Proses pencampuran material, dengan mencampurkan matrik material (bahan baku) dengan material penguat lainnya secara merata. Setelah terbentuknya produk, biasanya dilakukan uji karakterisasi dengan menggunakan alat FT-IR dan XRD. Hal ini bertujuan untuk mengetahui apakah produk yang terbentuk sudah sesuai dengan yang diinginkan, baik itu keefektifitasannya maupun kelayakan produk. Jenis-jenis alat yang digunakan dalam proses blending dapat dilihat pada gambar 1 .

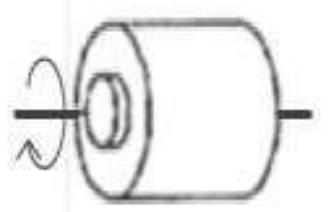

a) Rotating drum

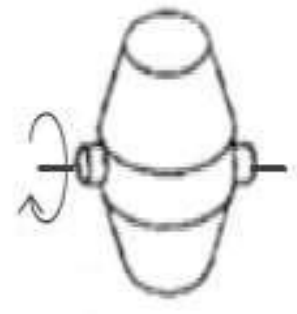

b) Rotating double cone

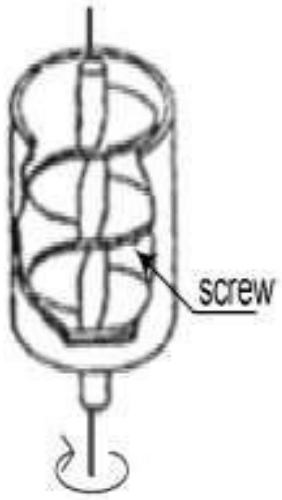

c) screw mixer

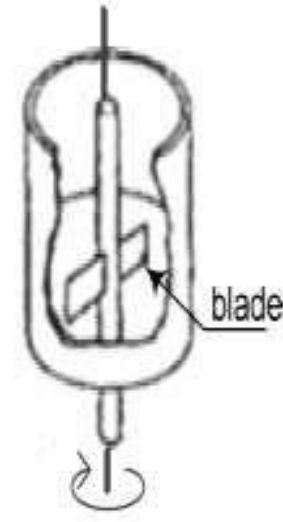

d) blade mixer

Gambar 1. Tipe alat blending[102]

Pada tahun 2011, metode blended digunakan untuk mencampurkan Vitamin E dengan UHMWPE (Ultra high molecular weight polyethylene) yang berfungsi untuk mereduksi kemampuan adhesi bakteri. Ultra high molecular weight polyethylene[103-107] (UHMWPE) adalah bahan pilihan untuk penggantian sendi; mengurangi adhesi S. epidermidis ke polimer yang bisa menjadi sarana untuk mengurangi infeksi. Campuran Vitamin E dengan UHMWPE (VE-PE) bisa memiliki potensi untuk mengurangi kemampuan perekat S.epidermidis jika data awal yang diamati pada galur terpilih ini lebih lanjut dikonfirmasi, karena keragaman di antara strain klinis sudah diketahui[32].

Pada tahun 2013, metode blended digunakan pada campuran pati / polivinil alkohol (PVA) untuk digunakan sebagai sumber karbon padat (SCS) yang disiapkan dengan memadukan PVA dan pati gelatin dalam sistem larutan berair. PVA berfungsi sebagai bahan kerangka dan pati sebagai sumber karbon. Optimalisasi kandungan pati dan efek suhu diselidiki. Itu menunjukkan bahwa efisiensi denitrifikasi yang lebih tinggi dapat dicapai dengan lebih banyak pati dalam bahan. Tingkat denitrifikasi meningkat ketika suhu operasi dinaikkan dari 
$23^{\circ} \mathrm{C}$ hingga $30^{\circ} \mathrm{C}$ dan kemudian $37^{\circ} \mathrm{C}$. Bahan berbasis pati yang dikembangkan dalam penelitian ini dapat digunakan sebagai sumber karbon padat untuk pembuangan nitrogen tersier dari limbah sekunder[34].

Pada tahun 2014, metode blended digunakan pada pembuatan sutera karena memiliki kualitas yang unggul. Metode blended pada pembuatan ini menggunakan protein adhesif rekombinan rekombinan RGD peptida (MAP-RGD) dengan paduan ulat sutera fibroin (SF). Pencampuran MAP-RGD memberikan daya rekat pada mikro berbagai biomolekul. Serat SF yang dicampur MAP-RGD mendukung peningkatan adhesi, proliferasi, dan penyebaran sel mamalia serta pelekatan biomolekul yang efisien, termasuk karbohidrat dan protein. Selain itu, hidrofilisitas, pembengkakan, dan biodegradabilitas material SF yang MAP-RGD-blended ditingkatkan tanpa penghalang penting dari sifat mekanis asli SF. Oleh karena itu, bahan berserat sutra perekat dapat berhasil digunakan dalam aplikasi rekayasa biomedis yang beragam[43].

Sedangkan pada tahun 2015, metode blended digunakan dalam mensintesis elektrokatalis $\mathrm{NiO}-\mathrm{Ni}$. Inti logam $\mathrm{Ni}$ bersisik yang dilapisi lebih dalam oleh lapisan $\mathrm{NiO}$ yang berkerut $\mathrm{Cr}_{2} \mathrm{O}_{3}$ yang disintesis pada substrat busa logam. $\mathrm{Cr}_{2} \mathrm{O}_{3}$ yang stabil secara kimia sangat penting untuk mencegah oksidasi inti Ni. Elektrokatalis yang sangat aktif dan stabil memungkinkan elektroliser alkali beroperasi pada $20 \mathrm{~mA} \mathrm{~cm}^{-2}$ pada tegangan lebih rendah dari 1,5 $\mathrm{V}$, yang berlangsung lebih lama dari 3 minggu tanpa pembusukan. Katalis logam non-mulia menghasilkan efisiensi tinggi sekitar $15 \%$ untuk pemisahan air yang dipicu cahaya menggunakan gas sel surya[44].

Pada tahun 2016, metode blended digunakan dalam pencampuran nanofibers untuk balutan luka antibakteri. PVA-Plur-PEI nanofibers mengandung berbagai rasio $\mathrm{NP} \mathrm{TiO}_{2}$. PVA-Plu-PEI nanofibers memiliki diameter rata-rata $220 \mathrm{~nm}$, dan nanofibers PVA-Plur-PEI / $\mathrm{TiO}_{2}$ memiliki $255 \mathrm{~nm}$. Selain itu, sifat antimikroba dari komposit dipelajari oleh inhibisi zona terhadap bakteri negatif. Hasilnya menunjukkan aktivitas antibakteri yang tinggi. Hasil dari pengujian antibakteri ini menunjukkan bahwa nanofibers PVA-Plur-PEI / $\mathrm{TiO}_{2}$ mungkin efektif dalam pengobatan antibakteri pada perawatan luka. Dengan demikian, campuran tersebut sangat menjanjikan dalam penerapan balutan luka[33].

Pada tahun 2017, metode blended digunakan dalam campuran jerami padi sebagai sumber biopolimer. Jerami padi adalah limbah pertanian yang terdiri dari selulosa yang dapat dikonversi menjadi karboksimetil selulosa dari jerami padi (CMCr) sebagai potensi biomaterial. $\mathrm{CMCr}$ menunjukkan potensi sebagai pengganti hingga 50\% dari CMC komersial tanpa perubahan dalam sifat mekanik dan permeabilitas. Campuran plasticizer (10\% gliserol dan $10 \%$ minyak zaitun) memberikan film campuran dengan penghalang air yang baik dan sifat mekanik yang sebanding dengan $20 \%$ plasticizer individu. Analisis komponen prinsip (PC) dengan 2 PC menjelaskan sekitar $81 \%$ dari total varians, adalah alat yang berguna untuk memilih rasio plasticizer yang cocok untuk produksi film campuran. Oleh karena itu, $\mathrm{CMCr}$ dapat digunakan untuk membentuk film dan pelapis yang dapat dimakan sebagai bahan kemasan ramah lingkungan yang terbarukan[35].

Pada tahun 2018, metode blended digunakan dalam karakterisasi modifiksai Polypropylene. Polypropylene[108-110] (PP) berisi aplikasi yang menjanjikan dalam kabel termoplastik untuk transmisi listrik tegangan tinggi saat ini (HVDC) karena sifat termal dan 
dielektriknya yang luar biasa. Namun, masalah ketangguhan yang buruk dan muatan ruang telah membatasi penerapan PP murni dalam kabel HVDC. Dalam penelitian ini, elastomer poliolefin (POE) dan nano-silika dicampur secara menyeluruh dan ditambahkan ke dalam campuran PP dengan metode pelelehan. Scanning electron microscopy (SEM) digunakan untuk mengamati dispersi POE dan nanopartikel. Sifat termal dikarakterisasi oleh differential scanning calorimetry (DSC) dan dynamic mechanical analysis (DMA)[11].

Sifat elastomerik komposit meningkat karena POE terdispersi dapat mentransfer dan menghomogenkan kekuatan mekanis eksternal. Hasil DC yang menurun menunjukkan bahwa kekuatan kegagalan dari komposit dengan 10 phr POE dan 1 phr nano-silica jelas meningkat. Hasil elektro-akustik pulpa (PEA) menunjukkan bahwa injeksi dan akumulasi muatan ruang meningkat dengan pengenalan POE, sementara itu tertahan oleh efek kolektif yang disebabkan oleh pengisian nano-silika. Difraksi sinar X (XRD) spektogram menunjukkan bahwa struktur sekunder paling dominan ada di komposit PP, POE, dan nano-silika, dan bahwa struktur yang dominan di sekitar nanopartikel berkontribusi pada peningkatan kekuatan kerusakan. Sifat mekanik dan dielektrik dimodifikasi secara sinergis, yang menjadikan PP yang dimodifikasi sebagai bahan insulasi yang sesuai untuk kabel HVDC[11].

Pada tahun 2018 juga dilakukan penelitian sintesis curcumin/chitin[84, 111-117]. Pada penelitian ini, elastomer poliuretan chitin-kurkumin (PUEs) disiapkan dengan teknik polimerisasi pertumbuhan langkah menggunakan hidroksi terminasi polibutadiena (HTPB), heksametilena diisosianat (HDI), kitin dan kurkumin. Karakterisasi molekul dilakukan dengan menggunakan FTIR dan SS (1) teknik HNMR. Morfologi permukaan dan stabilitas termal dipelajari dengan scanning electron microscopy (SEM) dan analisis gravimetri termal (TGA), masing-masing. Tingkat penyerapan dan pembengkakan karakter juga ditentukan dalam air serta di DMSO. Perilaku kristal elastomer siap diperiksa dengan menggunakan X-ray difraksi (XRD) dan diferensial scanning kalorimeter (DSC). Hasil yang didapat yaitu bahwa kristalinitas elastomer meningkat dengan meningkatkan kandungan chitin karena pembentukan struktur yang lebih teratur[84].

Secara umum, tujuan metode blended ini adalah untuk mencampurkan beberapa bahan yang dapat menghasilkan suatu produk baru. Secara khusus, tujuan metode blended yaitu :

a. Metode blended dapat memperbaiki produk-produk yang rusak atau tidak sesuai spesifikasinya.

b. Metode blended dapat mengubah produk yang bermutu atau berkualitas rendah menjadi bermutu tinggi.

c. Metode blended dapat mengubah atau memodifikasi produk lama menjadi produk yang lebih inovasi (produk baru).

Proses blending biasanya dapat dilakukan sampai dengan kapasitas 4000kg/jam. Bahan yang dicampurkan meliputi pelet, regrind, konsentrat, bubuk, bentuk cair dan flake. Pada proses blended hal yang harus diperhatikan adalah material yang digunakan harus sesuai dengan formulasi. Jika tidak, maka kualitas produk (material baru) dapat menurun. Oleh karena itu, keakurasian timbangan sangatlah penting dalam proses ini. 


\section{Kesimpulan}

Teknik blended adalah salah satu teknik dalam sintesis material. Prinsip kerja blended adalah menggabungkan atau mencampurkan bahan-bahan material dengan perbandingan jumlah yang sesuai. Pada teknik blended sudah banyak diaplikasikan dalam pembuatan industri sutera, karena memiliki kualitas yang unggul dan memberikan daya rekat yang kuat. Selain itu pada proses blended juga diterapkan dalam pembuatan kabel termoplastik yang membuat kabel lebih bertransmisi tinggi. 


\section{REFERENSI}

[1] K. Ahn, J.H. Lee, H. Kim, J. Kim, Enhanced carbon tolerance of Ir alloyed Ni-Based metal for methane partial oxidation, Heliyon, 4 (2018) e00652.

[2] P.L. Bhutiya, N. Misra, M. Abdul Rasheed, S. Zaheer Hasan, Nested seaweed cellulose fiber deposited with cuprous oxide nanorods for antimicrobial activity, International journal of biological macromolecules, 117 (2018) 435-444.

[3] A.A. Rahadian Zainul, Hermansyah Aziz, Syukri Arief, Syukri, Edison Munaf, Photoelectrosplitting Water Mechanism at Carbon Electrode Surface using Indoor lights, (2018).

[4] B.O. Rahadian Zainul, Indang Dewata, Jon Efendi Thermal and Surface Evaluation on The Process of Forming a Cu2O/CuO Semiconductor Photocatalyst on a Thin Copper Plate, IOP Conference Series: Materials Science and Engineering, 335 (2018) 012039.

[5] A.A. Rahadian Zainul, Hermansyah Aziz, Syukri Arief, Syukri, Edison Munaf, Disain Geometri Reaktor Fotosel Cahaya Ruang, Jurnal Riset Kimia, 8 (2015) 131.

[6] A.A. Rahadian Zainul, Hermansyah Aziz, Syukri Arief, Syukri Darajat, Modifikasi dan Karakteristik I-V Sel Fotovoltaik Cu2O/Cu-Gel Na2SO4 Melalui Illuminasi Lampu Neon, EKSAKTA Berkeley Ilmiah Bidang MIPA, 2 (2015) 50.

[7] M. Suci Rahma Yani, Rahadian Zainul, Aktivasi Tanah Napa dan Pengaruhnya Terhadap Adsorpsi Ion Timbal (II)/Pb2+, (2018).

[8] E.M. Mawardi Anwar, Soleh Kosela, Widayanti Wibowo, Rahadian Zainul, Study of Pb(II) Biosorption from Aqueous Solution Using Immobilized Spirogyra Subsalsa Biomass, Journal of Chemical and Pharmaceutical Research, 7 (2015) 715-722.

[9] I.L. Desy Kurniawati, Salmariza Sy Harmiwati, Zulkarnain Chaidir, Edison Munaf, Rahmiana Zein, Hermansyah Aziz, Rahadian Zainul, Biosorption of Pb (II) from Aqueous Solutions Using Column Method by Lengkeng (Euphoria logan lour) Seed and Shell, Journal of Chemical and Pharmaceutical Research,, 7 (2015) 872-877.

[10] M. Lemieszewska, A. Polanowski, T. Wilusz, A. Sokolowska, A. Zambrowicz, K. Mikolajewicz, J. Macala, J. Rymaszewska, A. Zablocka, Isolation and Characterization of NP-POL Nonapeptide for Possible Therapeutic Use in Parkinson's Disease, Oxidative medicine and cellular longevity, 2018 (2018) 3760124.

[11] X. Chi, L. Cheng, W. Liu, X. Zhang, S. Li, Characterization of Polypropylene Modified by Blending Elastomer and Nano-Silica, Materials, 11 (2018).

[12] J. Fito, N. Tefera, H. Kloos, S.W.H. Van Hulle, Anaerobic treatment of blended sugar industry and ethanol distillery wastewater through biphasic high rate reactor, Journal of environmental science and health. Part A, Toxic/hazardous substances \& environmental engineering, 
[13] J. Li, X. Xing, J. Li, M. Shi, A. Lin, C. Xu, J. Zheng, R. Li, Preparation of thiol-functionalized activated carbon from sewage sludge with coal blending for heavy metal removal from contaminated water, Environmental pollution, 234 (2018) 677-683.

[14] R. Longo, J.W. Blackman, G. Antalick, P.J. Torley, S.Y. Rogiers, L.M. Schmidtke, Harvesting and blending options for lower alcohol wines: a sensory and chemical investigation, Journal of the science of food and agriculture, 98 (2018) 33-42.

[15] S. Mohajer, M. Rezaei, S.F. Hosseini, Physico-chemical and microstructural properties of fish gelatin/agar bio-based blend films, Carbohydrate polymers, 157 (2017) 784-793.

[16] B.A. Gross, A.P. Jadhav, T.G. Jovin, B.T. Jankowitz, Dump the pump: manual aspiration thrombectomy (MAT) with a syringe is technically effective, expeditious, and cost-efficient, Journal of neurointerventional surgery, 10 (2018) 354-357.

[17] M.T. Froehler, Comparison of Vacuum Pressures and Forces Generated by Different Catheters and Pumps for Aspiration Thrombectomy in Acute Ischemic Stroke, Interventional neurology, 6 (2017) 199-206.

[18] H. Yao, S. Toan, L. Huang, M. Fan, Y. Wang, A.G. Russell, G. Luo, W. Fei, TiO(OH)2 highly effective catalysts for optimizing $\mathrm{CO} 2$ desorption kinetics reducing $\mathrm{CO} 2$ capture cost: A new pathway, Scientific reports, 7 (2017) 2943.

[19] G. Verma, C. Vishwakarma, C.V. Dharmadhikari, U.D. Rapol, A compact atomic beam based system for Doppler-free laser spectroscopy of strontium atoms, The Review of scientific instruments, 88 (2017) 033103.

[20] O.C. Olojede, M.J. Ford, J.P. Jacob, T. Ao, A.J. Pescatore, S.A. Adedokun, The effect of drying method temperature, collection method, and marker type on apparent ileal amino acid digestibility in 21-day-old broilers fed corn-soybean meal-barley based diet, Poultry science, 97 (2018) 2106-2112.

[21] L.M. Bryson, D. Fernandez Rivas, C. Boutsioukis, Cleaning of used rotary nickel-titanium files in an ultrasonic bath by locally intensified acoustic cavitation, International endodontic journal, 51 (2018) 457-468.

[22] R. Zainul, Disain dan Modifikasi Kolektor dan Reflektor Cahaya pada Panel Sel Surya $\mathrm{Al} / \mathrm{Cu} 2 \mathrm{O}-\mathrm{Gel} \mathrm{Na} 2 \mathrm{SO} 4$, Research Report, (2015).

[23] R. Zainul, Determination of the half-life and the quantum yield of $\mathrm{ZnO}$ semiconductor photocatalyst in humic acid, (2016).

[24] C. Monrabal-Martinez, J. Aberle, T.M. Muthanna, M. Orts-Zamorano, Hydrological benefits of filtering swales for metal removal, Water research, 145 (2018) 509-517.

[25] R.S. Azwir Anhar, Rahadian Zainul, Measurement of Glycemic Index of West Sumatera Local Rice Genotypes for Healthy Food Selection, (2016).

[26] L.H. Saputri, isolasi nano selulosa dari ampas tebu dengan proses blending pada berbagai variasi

konsentrasi,

(2018). 
[27] J. Siritapetawee, W. Limphirat, W. Wongviriya, J. Maneesan, W. Samosornsuk, Isolation and characterization of a galactose-specific lectin $(\mathrm{EantH})$ with antimicrobial activity from Euphorbia antiquorum L. latex, International journal of biological macromolecules, 120 (2018) 1846-1854.

\section{[28] R.Z. Neri Fadjria, ISOLATION AND MOLECULAR IDENTIFICATION OF FRESHWATER MICROALGAE IN MANINJAU LAKE WEST SUMATERA, (2018).}

[29] R. Ojarinta, J. Saarinen, C.J. Strachan, O. Korhonen, R. Laitinen, Preparation and characterization of multi-component tablets containing co-amorphous salts: combining multimodal non-linear optical imaging with established analytical methods, European journal of pharmaceutics and biopharmaceutics : official journal of Arbeitsgemeinschaft fur Pharmazeutische Verfahrenstechnik e.V, (2018).

[30] I.J. Aragon, H. Ceballos, D. Dufour, M.G. Ferruzzi, Pro-vitamin A carotenoids stability and bioaccessibility from elite selection of biofortified cassava roots (Manihot esculenta, Crantz) processed to traditional flours and porridges, Food \& function, 9 (2018) 4822-4835.

[31] M. Asrofi, H. Abral, Y.K. Putra, S.M. Sapuan, H.J. Kim, Effect of duration of sonication during gelatinization on properties of tapioca starch water hyacinth fiber biocomposite, International journal of biological macromolecules, 108 (2018) 167-176.

[32] G. Banche, P. Bracco, A. Bistolfi, V. Allizond, M. Boffano, L. Costa, A. Cimino, A.M. Cuffini, E.M. Del Prever, Vitamin E blended UHMWPE may have the potential to reduce bacterial adhesive ability, Journal of orthopaedic research : official publication of the Orthopaedic Research Society, 29 (2011) 1662-1667.

[33] M.R. El-Aassar, G.F. El Fawal, N.M. El-Deeb, H.S. Hassan, X. Mo, Electrospun Polyvinyl Alcohol/ Pluronic F127 Blended Nanofibers Containing Titanium Dioxide for Antibacterial Wound Dressing, Applied biochemistry and biotechnology, 178 (2016) 1488-1502.

[34] P. Li, J. Zuo, W. Xing, L. Tang, X. Ye, L. Zaixing, L. Yuan, K. Wang, H. Zhang, Starch/polyvinyl alcohol blended materials used as solid carbon source for tertiary denitrification of secondary effluent, Journal of environmental sciences, 25 (2013) 1972-1979.

[35] P. Rodsamran, R. Sothornvit, Rice stubble as a new biopolymer source to produce carboxymethyl cellulose-blended films, Carbohydrate polymers, 171 (2017) 94-101.

[36] I.D. Rahadian Zainul, Determination of pH-BOD-COD and degradation in batang arau watersheds at Padang city, (2018).

[37] G.S. Ghugare, V.D. Nimkande, K. Khairnar, Isolation and Enrichment of Bacteriophages by Membrane Filtration Immobilization Technique, Current protocols in cell biology, 79 (2018) e41.

[38] T.J. Gutierrez, Plantain flours as potential raw materials for the development of gluten-free functional foods, Carbohydrate polymers, 202 (2018) 265-279.

[39] S. Baghaie, M.T. Khorasani, A. Zarrabi, J. Moshtaghian, Wound healing properties of PVA/starch/chitosan hydrogel membranes with nano Zinc oxide as antibacterial wound dressing material, Journal of biomaterials science. Polymer edition, 28 (2017) 2220-2241. 
[40] M. Ruddy, D.P. FitzPatrick, K.T. Stanton, Preparation of morselised bone for impaction grafting using a blender method, Journal of the mechanical behavior of biomedical materials, 78 (2018) 91-95.

[41] M. Luo, X. Yu, W. Zhao, R. Xu, Y. Liu, H. Shen, Polymer-Promoted Synthesis of Porous TiO2 Nanofibers Decorated with N-Doped Carbon by Mechanical Stirring for High-Performance Li-Ion Storage, ACS applied materials \& interfaces, (2018).

[42] R. Zainul, Effect of Temperature and Particle Motion against the ability of $\mathrm{ZnO}$ Semiconductor Photocatalyst in Humic Acid, (2018).

[43] Y.J. Yang, Y. Kwon, B.H. Choi, D. Jung, J.H. Seo, K.H. Lee, H.J. Cha, Multifunctional adhesive silk fibroin with blending of RGD-bioconjugated mussel adhesive protein, Biomacromolecules, 15 (2014) 1390-1398.

[44] M. Gong, W. Zhou, M.J. Kenney, R. Kapusta, S. Cowley, Y. Wu, B. Lu, M.C. Lin, D.Y. Wang, J. Yang, B.J. Hwang, H. Dai, Blending Cr2O3 into a NiO-Ni electrocatalyst for sustained water splitting, Angewandte Chemie, 54 (2015) 11989-11993.

[45] D.A. Bichara, C.C. O'Brien, B.N. Doshi, G.P. Nielsen, E. Oral, O.K. Muratoglu, Residual Byproducts of Peroxide Crosslinked Vitamin E-Blended Ultrahigh Molecular Weight Polyethylene, The Journal of arthroplasty, 33 (2018) 2666-2670.

[46] F. Claret, S. Grangeon, A. Loschetter, C. Tournassat, W. De Nolf, N. Harker, F. Boulahya, S. Gaboreau, Y. Linard, X. Bourbon, A. Fernandez-Martinez, J. Wright, Deciphering mineralogical changes and carbonation development during hydration and ageing of a consolidated ternary blended cement paste, IUCrJ, 5 (2018) 150-157.

[47] S. Geng, J. Wei, Y. Aitomaki, M. Noel, K. Oksman, Well-dispersed cellulose nanocrystals in hydrophobic polymers by in situ polymerization for synthesizing highly reinforced bio-nanocomposites, Nanoscale, 10 (2018) 11797-11807.

[48] F. Hashempour-Baltork, M. Torbati, S. Azadmard-Damirchi, G. Peter Savage, Chemical, Rheological and Nutritional Characteristics of Sesame and Olive Oils Blended with Linseed Oil, Advanced pharmaceutical bulletin, 8 (2018) 107-113.

[49] Y. Knop, A. Peled, Sustainable Blended Cements-Influences of Packing Density on Cement Paste Chemical Efficiency, Materials, 11 (2018).

[50] T. Narancic, S. Verstichel, S. Reddy Chaganti, L. Morales-Gamez, S.T. Kenny, B. De Wilde, R. Babu Padamati, K.E. O'Connor, Biodegradable Plastic Blends Create New Possibilities for End-of-Life Management of Plastics but They Are Not a Panacea for Plastic Pollution, Environmental science \& technology, (2018).

[51] A.R. Norizzah, K. Nur Azimah, O. Zaliha, Influence of enzymatic and chemical interesterification on crystallisation properties of refined, bleached and deodourised (RBD) palm oil and RBD palm kernel oil blends, Food research international, 106 (2018) 982-991.

[52] E. Oral, B.N. Doshi, R.M. Gul, A.L. Neils, S. Kayandan, O.K. Muratoglu, Peroxide cross-linked UHMWPE blended with vitamin E, Journal of biomedical materials research.
Part
B, Applied
biomaterials,
105
(2017)
1379-1389. 
[53] Y. Shen, C. Du, J. Zhou, F. Ma, Application of Nano Fe(III)-Tannic Acid Complexes in Modifying Aqueous Acrylic Latex for Controlled-Release Coated Urea, Journal of agricultural and food chemistry, 65 (2017) 1030-1036.

[54] B. Wu, N. Takeshita, Y. Wu, S. Vijayavenkataraman, K.Y. Ho, W.F. Lu, J.Y.H. Fuh, Pluronic F127 blended polycaprolactone scaffolds via e-jetting for esophageal tissue engineering, Journal of materials science. Materials in medicine, 29 (2018) 140.

[55] H. Wu, S. Xu, H. Shao, L. Li, Y. Cui, C. Wang, Single component Mn-doped perovskite-related $\mathrm{CsPb} 2 \mathrm{ClxBr} 5-\mathrm{x}$ nanoplatelets with a record white light quantum yield of 49\%: a new single layer color conversion material for light-emitting diodes, Nanoscale, 9 (2017) 16858-16863.

[56] Z. Wu, S. Wang, Z. Luo, L. Chen, H. Meng, J. Zhao, Physico-chemical properties and gasification reactivity of co-pyrolysis char from different rank of coal blended with lignocellulosic biomass: Effects of the cellulose, Bioresource technology, 235 (2017) 256-264.

[57] J. Zhou, R. Wang, X. Wu, B. Xu, Fiber-Content Measurement of Wool-Cashmere Blends Using Near-Infrared Spectroscopy, Applied spectroscopy, 71 (2017) 2367-2376.

[58] F. Zunino, D.P. Bentz, J. Castro, Reducing setting time of blended cement paste containing high-SO3 fly ash (HSFA) using chemical/physical accelerators and by fly ash pre-washing, Cement \& concrete composites, 90 (2018) 14-26.

[59] F. Qi, Y.X. Sun, Z. Yang, C.F. Hu, X.M. Chang, H.Y. Hu, [Formation of Brominated Disinfection By-products in Low Temperature Multi-effect Distillation (LT-MED) Process for Seawater Desalination], Huan jing ke xue= Huanjing kexue, 38 (2017) 2364-2372.

[60] K. Xu, G. He, J. Qin, X. Cheng, H. He, D. Zhang, W. Peng, High-efficient extraction of principal medicinal components from fresh Phellodendron bark (cortex phellodendri), Saudi journal of biological sciences, 25 (2018) 811-815.

[61] A.B. Cutillas, A. Carrasco, R. Martinez-Gutierrez, V. Tomas, J. Tudela, Thyme essential oils from Spain: Aromatic profile ascertained by GC-MS, and their antioxidant, anti-lipoxygenase and antimicrobial activities, Journal of food and drug analysis, 26 (2018) $529-544$.

[62] Y. Wu, Y. Kang, L. Zhang, D. Qu, X. Cheng, L. Feng, Performance and fouling mechanism of direct contact membrane distillation (DCMD) treating fermentation wastewater with high organic concentrations, Journal of environmental sciences, 65 (2018) 253-261.

[63] J.Y. Choi, S.M. Lee, H.J. Lee, Y.S. Kim, Characterization of aroma-active compounds in Chinese quince (Pseudocydonia sinensis Schneid) by aroma dilution analyses, Food research international, 105 (2018) 828-835.

[64] M. Gryta, The long-term studies of osmotic membrane distillation, Chemicke zvesti, 72 (2018) 99-107.

[65] J.L. Burger, T.M. Lovestead, M. LaFollette, T.J. Bruno, Application of the Advanced Distillation Curve Method to the Comparison of Diesel Fuel Oxygenates: 2,5,7,10-Tetraoxaundecane (TOU), 2,4,7,9-Tetraoxadecane (TOD), and Ethanol/Fatty Acid 
Methyl Ester (FAME) Mixtures, Energy \& fuels : an American Chemical Society journal, 31 (2017) 7800-7808.

[66] S. Tavakoli, H. Vatandoost, R. Zeidabadinezhad, R. Hajiaghaee, A. Hadjiakhoondi, M.R. Abai, N. Yassa, Gas Chromatography, GC/Mass Analysis and Bioactivity of Essential Oil from Aerial Parts of Ferulago trifida: Antimicrobial, Antioxidant, AChE Inhibitory, General Toxicity, MTT Assay and Larvicidal Activities, Journal of arthropod-borne diseases, 11 (2017) 414-426.

[67] J.M. Venegas, W.P. McDermott, I. Hermans, Serendipity in Catalysis Research: Boron-Based Materials for Alkane Oxidative Dehydrogenation, Accounts of chemical research, (2018).

[68] D.H. Jung, S.H. Rajendran, J.P. Jung, Effect of $\mathrm{ZrO}$ (2) Nanomaterials on Wettability and Interfacial Characteristics of Al-19Cu-11Si-2Sn Filler Metal for Low Temperature $\mathrm{Al}$ to $\mathrm{Cu}$ Dissimilar Brazing, Nanomaterials, 8 (2018).

[69] X. Hua, G. Gao, S. Pan, High-affinity graphene oxide-encapsulated magnetic Zr-MOF for pretreatment and rapid determination of the photosensitizers hematoporphyrin and hematoporphyrin monomethyl ether in human urine prior to UPLC-HRMS, Analytical and bioanalytical chemistry, (2018).

[70] A.F. Martins, N.C. Bennett, S. Clavel, H. Groenewald, S. Hensman, S. Hoby, A. Joris, P.R. Manger, M.C. Milinkovitch, Locally-curved geometry generates bending cracks in the African elephant skin, Nature communications, 9 (2018) 3865.

[71] H. Jung, W.B. Yoon, The effect of intermittent drying on the cracking ratio of soybeans (Glycine max) at different relative humidity using reaction engineering approach modeling, Food science \& nutrition, 6 (2018) 1492-1500.

[72] H.K. Gurdeep Singh, S. Yusup, A.T. Quitain, T. Kida, M. Sasaki, K.W. Cheah, M. Ameen, Production of gasoline range hydrocarbons from catalytic cracking of linoleic acid over various acidic zeolite catalysts, Environmental science and pollution research international, (2018).

[73] N. Badwe, X. Chen, D.K. Schreiber, M.J. Olszta, N.R. Overman, E.K. Karasz, A.Y. Tse, S.M. Bruemmer, K. Sieradzki, Decoupling the role of stress and corrosion in the intergranular cracking of noble-metal alloys, Nature materials, 17 (2018) 887-893.

[74] D. Nogues-Bravo, F. Rodriguez-Sanchez, L. Orsini, E. de Boer, R. Jansson, H. Morlon, D.A. Fordham, S.T. Jackson, Cracking the Code of Biodiversity Responses to Past Climate Change, Trends in ecology \& evolution, 33 (2018) 765-776.

[75] A. Rahbari, M. Ramdin, L.J.P. van den Broeke, T.J.H. Vlugt, Combined Steam Reforming of Methane and Formic Acid To Produce Syngas with an Adjustable H2:CO Ratio, Industrial \& engineering chemistry research, 57 (2018) 10663-10674.

[76] J.F. White, K.L. Kingsley, S.K. Verma, K.P. Kowalski, Rhizophagy Cycle: An Oxidative Process in Plants for Nutrient Extraction from Symbiotic Microbes, Microorganisms, 6 (2018). 
[77] W.O. Alabi, $\mathrm{CO} 2$ reforming of $\mathrm{CH} 4$ on Ni-Al-Ox catalyst using pure and coal gas feeds: Synergetic effect of $\mathrm{CoO}$ and $\mathrm{MgO}$ in mitigating carbon deposition, Environmental pollution, 242 (2018) 1566-1576.

[78] Y. Zhou, C.M. Schroeder, Dynamically Heterogeneous Relaxation of Entangled Polymer Chains, Physical review letters, 120 (2018) 267801.

[79] J. Hu, V.V. Galvita, H. Poelman, G.B. Marin, Advanced Chemical Looping Materials for CO(2) Utilization: A Review, Materials, 11 (2018).

[80] X. Wei, S. Wang, Z. Hua, L. Chen, J. Shi, Metal-Organic Framework Nanosheet Electrocatalysts for Efficient H2 Production from Methanol Solution: Methanol-Assisted Water Splitting or Methanol Reforming?, ACS applied materials \& interfaces, 10 (2018) 25422-25428.

[81] T. Drost, S. Reimann, M. Frentzen, J. Meister, Effectiveness of photopolymerization in composite resins using a novel 445-nm diode laser in comparison to LED and halogen bulb technology, Lasers in medical science, (2018).

[82] A.M.F. Galal, M.M. Soltan, E.R. Ahmed, A.G. Hanna, Synthesis and biological evaluation of novel 5-chloro-N-(4-sulfamoylbenzyl) salicylamide derivatives as tubulin polymerization inhibitors, MedChemComm, 9 (2018) 1511-1528.

[83] M. Errezma, A.B. Mabrouk, A. Magnin, A. Dufresne, S. Boufi, Surfactant-free emulsion Pickering polymerization stabilized by aldehyde-functionalized cellulose nanocrystals, Carbohydrate polymers, 202 (2018) 621-630.

[84] K. Mahmood, K.M. Zia, W. Aftab, M. Zuber, S. Tabasum, A. Noreen, F. Zia, Synthesis and characterization of chitin/curcumin blended polyurethane elastomers, International journal of biological macromolecules, 113 (2018) 150-158.

[85] L. Yan, Y. Cao, X. Li, B. He, Characterization of a dual fluidized bed gasifier with blended biomass/coal as feedstock, Bioresource technology, 254 (2018) 97-106.

[86] R. Zainul, Characterization of napa soil and adsorption of $\mathrm{Pb}$ (II) from aqueous solutions using on column method, (2015).

[87] R. Zainul, Synthesis and electrical properties of ZnO-ITO and Al-ITO thin film by spin coating technique through sol gel process, (2016).

[88] M.R. Campbell, K.K. Milam, K.R. Fisher, Body Fluid Processing Workspace Quality Improvement Initiative in a High-Volume Reference Laboratory, American journal of clinical pathology, 149 (2018) 434-441.

[89] M. Cox, K. Sandburg, Modeling Causal Relationships in Quality Improvement, Current problems in pediatric and adolescent health care, (2018).

[90] G. Gartlehner, M.T. Schultes, V. Titscher, L.C. Morgan, G.V. Bobashev, P. Williams, S.L. West, User testing of an adaptation of fishbone diagrams to depict results of systematic reviews, BMC medical research methodology, 17 (2017) 169. 
[91] A.T. Nathan, H.C. Kaplan, Tools and methods for quality improvement and patient safety in perinatal care, Seminars in perinatology, 41 (2017) 142-150.

[92] E.P. Tagge, A.S. Thirumoorthi, J. Lenart, C. Garberoglio, K.W. Mitchell, Improving operating room efficiency in academic children's hospital using Lean Six Sigma methodology, Journal of pediatric surgery, 52 (2017) 1040-1044.

[93] C.F. Azevedo, M.S. Bittencourt, Can coronary computed tomography angiography be the complete roadmap for chronic total occlusion management?, Heart, (2018).

[94] E. Bahl, T. Koomar, J.J. Michaelson, cerebroViz: an R package for anatomical visualization of spatiotemporal brain data, Bioinformatics, 33 (2017) 762-763.

[95] R.A. Berman, A.S. Gottlieb, Job Negotiations in Academic Medicine: Building a Competency-Based Roadmap for Residents and Fellows, Journal of general internal medicine, (2018).

[96] J. Buchanan, S. Wordsworth, Evaluating the Outcomes Associated with Genomic Sequencing: A Roadmap for Future Research, PharmacoEconomics - open, (2018).

[97] D.J. Hughes, D.A. Campbell, M.A. Doblin, J.C. Kromkamp, E. Lawrenz, C.M. Moore, K. Oxborough, O. Prasil, P.J. Ralph, M.F. Alvarez, D.J. Suggett, Roadmaps and Detours: Active Chlorophyll- a Assessments of Primary Productivity Across Marine and Freshwater Systems, Environmental science \& technology, (2018).

[98] D. Kotecha, J.J. Bax, C. Carrera, B. Casadei, B. Merkely, S.D. Anker, P.E. Vardas, P.P. Kearney, M. Roffi, M. Ros, A. Vahanian, F. Weidinger, R. Beeri, A. Budaj, P. Calabro, K. Czerwinska-Jelonkiewicz, F. D'Ascenzi, T. De Potter, K.F. Fox, J. Hartikainen, B. McAdam, D. Milicic, A.A. Pasquet, A. Sionis, S.M.A. Sohaib, C. Tsioufis, P.M.J. Verhorst, P. Kirchhof, E.S.C.S.D. Group, E.S.C.E. Conference, Roadmap for cardiovascular education across the European Society of Cardiology: inspiring better knowledge and skills, now and for the future, European heart journal, (2018).

[99] M. Volk, J. Mellinger, M.B. Bansal, Z.F. Gellad, M. McClellan, F. Kanwal, A Roadmap for Value-Based Payment Models among Patients with Cirrhosis, Hepatology, (2018).

[100] E.L. Wong, A.J. Winchester, V. Pareek, J. Madeo, M.K.L. Man, K.M. Dani, Pulling apart photoexcited electrons by photoinducing an in-plane surface electric field, Science advances, 4 (2018) eaat9722.

[101] R.Z. Zulkarnain Chaidir, Desi Nurakhbari, and Marniati Salim, Optimization of Spirulina Platensis Culture for Antioxidant Production, (2016).

[102] D. Seprianto, Perancangan Alat Blending/Mixing Menggunakan Perangkat Lunak CAD Autodesk Inventor Professional 2010, AUSTENIT, 3 (2011).

[103] J.Z. Xu, K.K. Wannomae, O.K. Muratoglu, E. Oral, Increased oxidative protection by high active vitamin $\mathrm{E}$ content and partial radiation crosslinking of UHMWPE, Journal of orthopaedic research : official publication of the Orthopaedic Research Society, 36 (2018) 1860-1867.

[104] P.O. Cubillos, V.O. Dos Santos, A.L.A. Pizzolatti, E. da Rosa, C.R.M. Roesler, Evaluation of Surface Finish and Dimensional Control of Tribological Metal-Ultra High 
Molecular Weight Polyethylene Pair of Commercially Available Hip Implants, The Journal of arthroplasty, 33 (2018) 939-944.

[105] S. Kayandan, B.N. Doshi, E. Oral, O.K. Muratoglu, Surface cross-linked ultra high molecular weight polyethylene by emulsified diffusion of dicumyl peroxide, Journal of biomedical materials research. Part B, Applied biomaterials, 106 (2018) 1517-1523.

[106] B.H. Currier, J.H. Currier, L.A. Holdcroft, D.W. Van Citters, Effectiveness of anti-oxidant polyethylene: What early retrievals can tell us, Journal of biomedical materials research. Part B, Applied biomaterials, 106 (2018) 353-359.

[107] S. Suner, N. Gowland, R. Craven, R. Joffe, N. Emami, J.L. Tipper, Ultrahigh molecular weight polyethylene/graphene oxide nanocomposites: Wear characterization and biological response to wear particles, Journal of biomedical materials research. Part B, Applied biomaterials, 106 (2018) 183-190.

[108] N.N. Petrova, V.V. Portnyagina, V.V. Mukhin, E.L. Shim, J.H. Cho, Preparation and Improved Physical Characteristics of Propylene Oxide Rubber Composites, Molecules, 23 (2018).

[109] H. Pandey, D.S. Thakur, U. Somashekar, R. Kothari, P. Agarwal, D. Sharma, Use of polypropylene mesh in contaminated and dirty strangulated hernias: short-term results, Hernia : the journal of hernias and abdominal wall surgery, (2018).

[110] Y. Tanimoto, M. Nagakura, Effects of polishing on surface roughness and hardness of glass-fiberreinforced polypropylene, Dental materials journal, (2018).

[111] M. Ahmad, G.M.A. Taweel, S. Hidayathulla, Nano-composites chitosan-curcumin synergistically inhibits the oxidative stress induced by toxic metal cadmium, International journal of biological macromolecules, 108 (2018) 591-597.

[112] R. Li, L. Deng, Z. Cai, S. Zhang, K. Wang, L. Li, S. Ding, C. Zhou, Liposomes coated with thiolated chitosan as drug carriers of curcumin, Materials science \& engineering. C, Materials for biological applications, 80 (2017) 156-164.

[113] J.A. Luckanagul, C. Pitakchatwong, P. Ratnatilaka Na Bhuket, C. Muangnoi, P. Rojsitthisak, S. Chirachanchai, Q. Wang, P. Rojsitthisak, Chitosan-based polymer hybrids for thermo-responsive nanogel delivery of curcumin, Carbohydrate polymers, 181 (2018) 1119-1127.

[114] T.S. Saranya, V.K. Rajan, R. Biswas, R. Jayakumar, S. Sathianarayanan, Synthesis, characterisation and biomedical applications of curcumin conjugated chitosan microspheres, International journal of biological macromolecules, 110 (2018) 227-233.

[115] A. Singh, Lavkush, A.K. Kureel, P.K. Dutta, S. Kumar, A.K. Rai, Curcumin loaded chitin-glucan quercetin conjugate: Synthesis, characterization, antioxidant, in vitro release study, and anticancer activity, International journal of biological macromolecules, 110 (2018) 234-244.

[116] T. Woraphatphadung, W. Sajomsang, T. Rojanarata, T. Ngawhirunpat, P. Tonglairoum, P. Opanasopit, Development of Chitosan-Based pH-Sensitive Polymeric Micelles Containing Curcumin for Colon-Targeted Drug Delivery, AAPS PharmSciTech, 19 (2018) 991-1000. 
[117] P. Yadav, A. Bandyopadhyay, A. Chakraborty, K. Sarkar, Enhancement of anticancer activity and drug delivery of chitosan-curcumin nanoparticle via molecular docking and simulation analysis, Carbohydrate polymers, 182 (2018) 188-198.

[118] Zainul, R. (2016, December 18). Design and Modification of Copper Oxide Electrodes for Improving Conversion Coefficient Indoors Lights (PV-Cell) Photocells. https://doi.org/10.31227/osf.io/pgn84

[119] Zainul, R., Oktavia, B., Dewata, I., \& efendi, j. (2017, February 4). Studi Dinamika Molekular dan Kinetika Reaksi pada Pembelahan Molekul Air untuk Produksi Gas Hidrogen. https://doi.org/10.31227/osf.io/876s3

[120] Zainul,Rahadian, Hermansyah Aziz, Syukri Arief, Syukri, Edison Munaf, Design of Photovoltaic Cell with Copper Oxide Electrode by using Indoor Lights, Research Journal of Pharmaceutical Biological and Chemical Science, 6 (2015) 353-361.

[121] M Mawardi, R Zainul, Characterization of PCC Cement by Addition of Napa Soil from Subdistrict Sarilamak 50 Kota District as Alternative Additional Material for Semen Padang, IOP Conference Series: Materials Science and Engineering, 335 (2018) 012034. 


\title{
a review
}

\section{Grinding : Teknik dan Prinsip Dasar pada Pengolahan Material}

\author{
Oki Marlina P*1, Laura Gevanny A ${ }^{2}$, Apri Yolla M S ${ }^{2}$, Rahadian Zainul ${ }^{2}$ \\ ${ }^{1}$ Chemistry Education, FMIPA, Universitas Negeri Padang, Indonesia \\ ${ }^{2}$ Chemistry Education, FMIPA, Universitas Negeri Padang, Indonesia \\ ${ }^{3}$ Chemistry Education, FMIPA, Universitas Negeri Padang, Indonesia \\ ${ }^{4}$ Physical Chemistry Laboratory, FMIPA, Universitas Negeri Padang, \\ Indonesia
}
*E-mail : Okimarlinapetri20@gmail.com, lauragevanny@gmail.com , apriyolla23@gmail.com, rahadianzmsiphd@yahoo.com

\begin{abstract}
Abstrak. Grinding merupakan suatu teknik pengecilan ukuran atau pengurangan ukuran dalam batas yang diinginkan. Review ini bertujuan untuk mendapatkan gambaran mengenai prinsip teknik grinding dalam pengolahan material. Metode seperti ini dilakukan untuk material dalam keadaan basah. Hasil pengolahan menggunakan metode grinding berupa material yang berukuran lebih kecil dari material sebelumnya atau dapat berupa mineral berharga yang terpisah dari mineral pengikutnya. Dalam beberapa pengolahan mineral non logam teknik grinding ini diperlukan untuk memenuhi persyaratan pasar.
\end{abstract}

Keyword : Prinsip, Grinding, Material

\section{Pendahuluan}

Dalam proses pengolahan material, proses awal yang dilakukan adalah kominusi. Dalam kominusi terdapat crushing, selain itu ada juga proses grinding(11-15). Grinding sendiri merupakan proses penghalusan bijih material dengan sistem menggiling. Proses dari grinding sendiri menggunakan beberapa jenis alat(22-26). Indikator atau ukuran pemisahan dari setiap alat ini pun akan berbeda-beda sesuai dengan keinginan dan hasil penghalusan bijih material yang diinginkan. Alat dari proses ini disebut grinder(32-35). Grinder akan mengecilkan ukuran dengan metode yang beragam sesuai dengan grinder yang digunakan. Proses grinding ini akan membantu dalam proses pengolahan material selanjutnya yakni proses konsentrasi(37-39).

Pengolahan material merupakan rangkaian kegiatan yang terdiri dari preparasi, konsentrasi, dewatering dan operasi tambahan lain yang diperlukan seperti feeding dan sampling $(40 ; 41)$. Pengolahan ini dilakukan secara mekanis dan bertujuan untuk memisahkan mineral berharga dari zat pengotornya agar menghasilkan prosuk yang kaya akan mineral berharga (konsentrasi) dan memiliki kadar tailing yang rendah(42-44). Salah satu tahapan yang paling penting dalam pengolahan material adalah preparasi, karena ketepatan reduksi material akan menentukan tahapan berikutnya dimana yang akan memisahkan mineral berharga dari mineral pengikitnya atau zat pengotornya(45-47). Tahap preparasi dalam mereduksi ukuran material akan dilakukan melalui proses grinding(48). 
Grinding merupakan teknik yang digunakan dalam penghalusan material dalam keadaan basah (wet condition) yang telah dihancurkan untuk mendapat batas ukuran halus yang diinginkan dari ukuran 5-250 mm menjadi 10-300 $\mu \mathrm{m}(49-52)$. Untuk mencapai batas ukuran halus yang diinginkan, maka terdapat berbagai alat grinding yang dapat digunakan(53; 54). Alat-alat yang digunakan tersebut bekerja menggunakan prinsip tekanan gerusan yang terjadi dalam suatu silinder berputar $(55 ; 56)$. Tahapan pengolahan dengan metode grinding ini biasanya menggunakan media penggerus berupa silinder baja, bola-bola baja/keramik dan batuan keras/natural(57-59).

Agar mendapatkan kualitas nilai ukuran yang baik, maka kualitas reduksi ukuran ini (comminution) sangat dipengaruhi oleh beberapa hal, diantaranya adalah adalah degree of liberation (derajat kebebasan) serta reduction ratio (rasio reduksi)(60-63). Derajat kebebasan adalah perbandingan antara jumlah partikel bebas dengan jumlah partikel total $(64 ; 65)$. Sedangkan rasio reduksi adalah perbandingan ukuran partikel yang masuk ke dalam proses (opening) dibanding dengan ukuran partikel yang keluar dari proses (discharge)(66-68).

\section{Metode}

Teknik grinding dapat dilakukan dengan mengkarakterisasi bahan baku yang akan digunakan. Kemudian pengolahan bahan baku tersebut akan melalui beberapa tahapan. Tahapan pertama dilakukan dengan mempersiapkan jenis alat grinding sesuai dengan kebutuhan(69; 70). Kemudian material atau bahan baku dimasukkan ke dalam silinder pada mesin grinding. Langkah selanjutnya adalah menghidupkan mesin grinding, maka perputaran dari mesin grinding akan menyebabkan bola-bola baja yang terdapat dalam mesin grinding ikut bergerak searah dengan perputaran mesin grinding(71-73). Pada ketinggian tertentu bola-bola baja tersebut akan terjatuh akibat adanya gravitasi. Sehingga bola-bola baja akan menumbuk material atau bahan baku yang diolah dan menyebabkan ukuran material menjadi lebih kecil dari ukuran sebelumnya(74-76). Pada proses grinding partikel direduksi dari 5 sampai $250 \mathrm{~mm}$ menjadi 10 sampai $300 \mu \mathrm{m}$, grinding biasanya dilakukan pada kondisi basah untuk mendapatkan slurry yang akan diumpankan pada proses concentration(77-82).

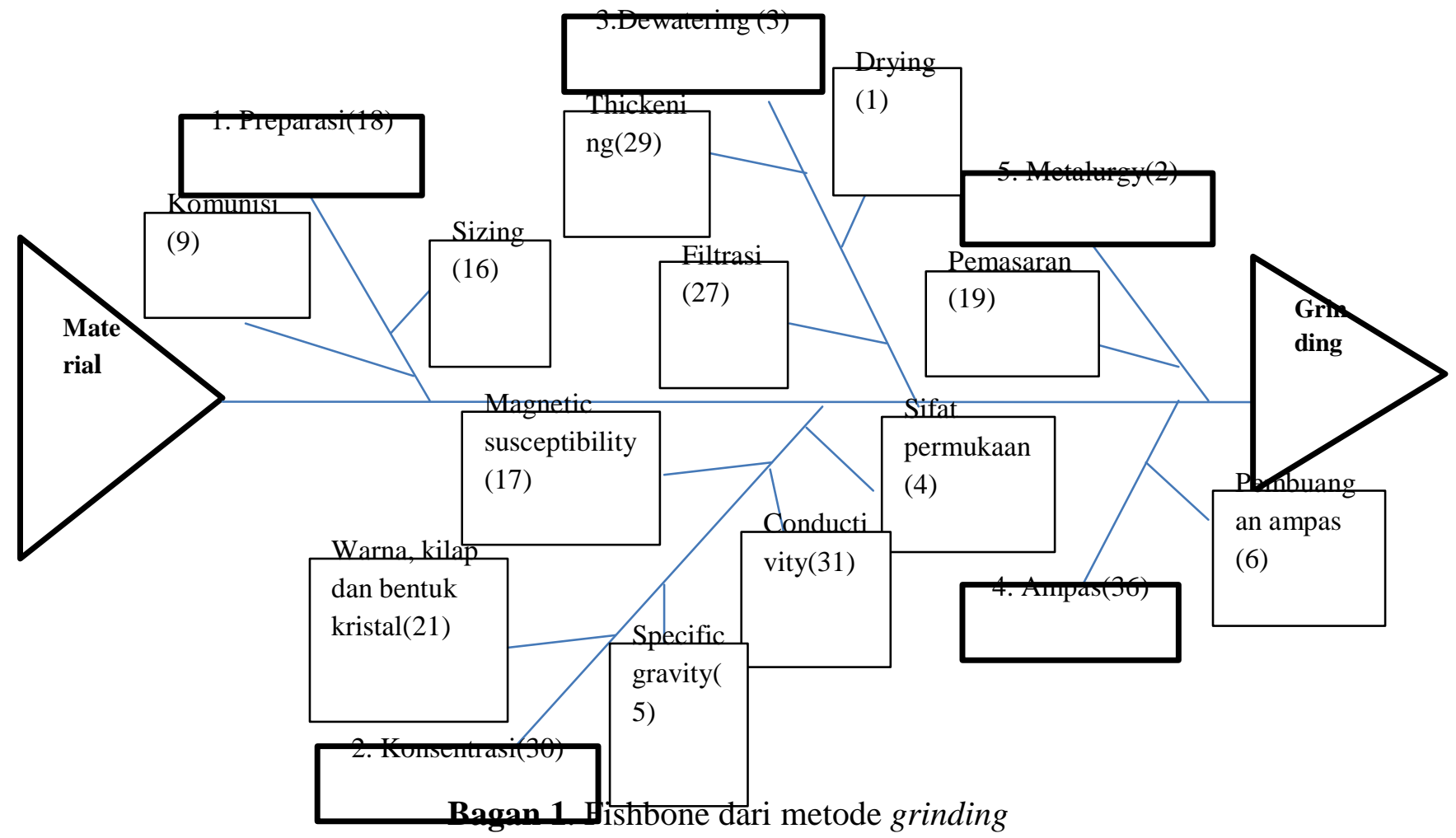




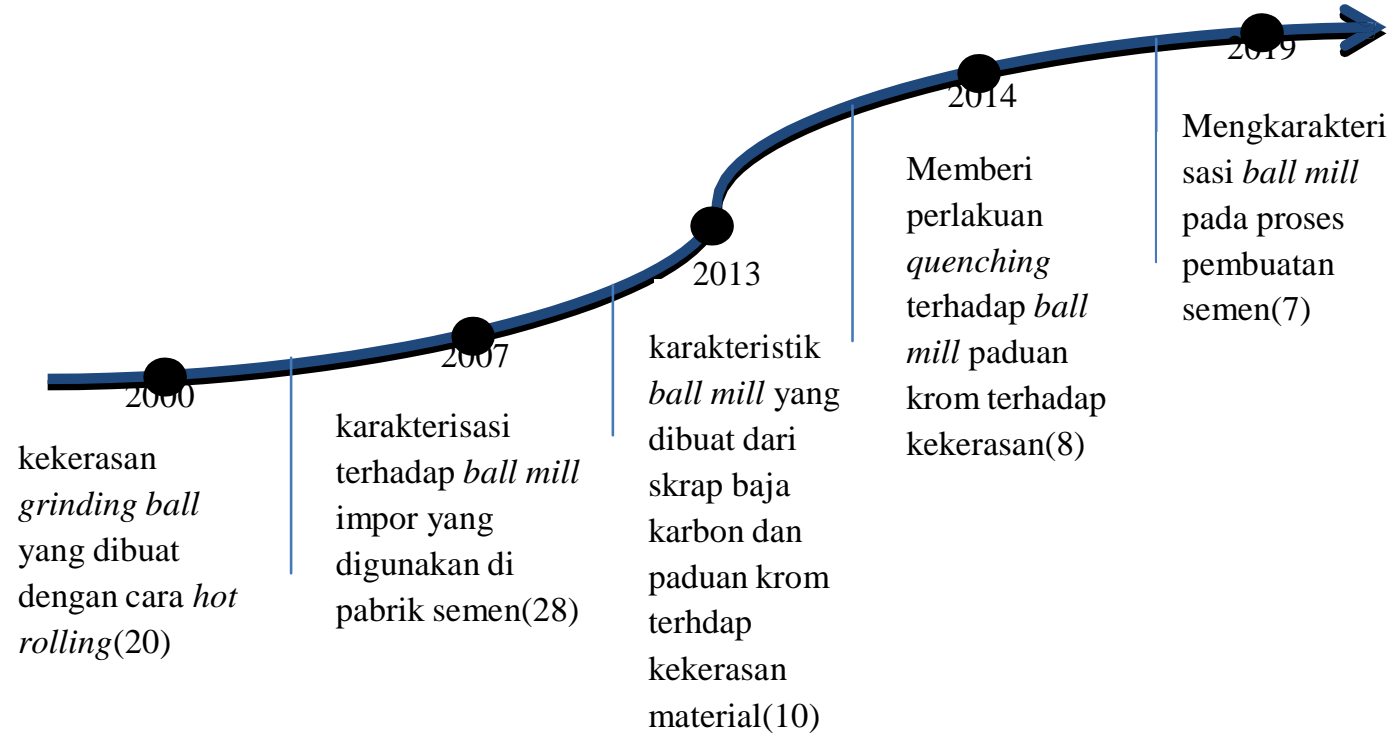

Bagan 2. Roadmap metode grinding

\section{Pembahasan}

Pengolahan Bahan Galian (mineral dressing) adalah pengolahan mineral dengan tujuan untuk memisahkan mineral berharga dengan gangue (zat pengotor) yang dilakukan secara mekanis, menghasilkan produk yang kaya mineral berharga (konsentrat) dan yang kadar tailing yang rendah. Salah satu tahap dalam proses pengolahan bahan galian adalah preparasi yang merupakan proses persiapan sebelum dilakukan proses konsentrasi. Dalam preparasi ini ada beberapa tahap yaitu komunusi dan sizing(83-85). Kominusi ialah mereduksi ukuran butir sehingga menjadi lebih kecil dari ukuran semula. Hal ini dapat dilakukan dengan crushing atau grinding $(86 ; 87)$. Grinding digunakan untuk proses basah dan kering, sedangkan crushing digunakan untuk proses kering saja. Selain untuk mereduksi ukuran butir, kominusi dimaksudkan juga untuk meliberasikan bijih, yaitu proses melepas mineral tersebut dari ikatan yang merupakan gangue mineral. Untuk melakukan hal ini digunakan alat crusher dan rinding mill(88; 89).

Pengolahan material dapat dilakukan dengan teknik grinding. Karena grinding digunakan untuk proses basah, maka daya yang diperlukan lebih sedikit dan ruang yang dibutuhkan juga lebih sedikit daripada untuk proses kering. Tujuan dari pengolahan dengan teknik grinding adalah untuk mereduksi atau mengurangi ukuran material, sehingga akan diperoleh material yang lebih kecil dari ukuran semula. Teknik grinding dapat memisahkan mineral berharga dari pengotornya (tailing), produk yang dihasilkan lebih kaya mineral berharga dan memiliki kadar tailing rendah(90-93). Grinding adalah proses terakhir dari comminution dimana proses kerjanya menggunakan prinsip gabungan dari impak (tumbukan) dan abrasi. Pada bijih dengan gerakan bebas dari media yang tidak terhubung dengan sesuatu, seperti rod, bola pejal, ataupun pebble. Pada proses grinding partikel direduksi dari 5 sampai $250 \mathrm{~mm}$ menjadi 10 sampai $300 \mu \mathrm{m}$, grinding biasanya dilakukan pada kondisi basah (wet condition) untuk mendapatkan slurry yang akan diumpankan pada proses concentration, meskipun ada beberapa keadaan dari grinding yang dilakukan pada kondisi kering (dry condition) namun dilakukan pada aplikasi yang terbatas(94-99).

Untuk mendapatkan kualitas ukuran yang diinginkan, maka kualitas dari pengolahan sangat dipengaruhi oleh beberapa hal, diantaranya degree of liberation (derajat kebebasan) dan reduction ratio ( rasio dari pengolahan)(100-102). Perbandingan jumlah partikel bebas 
dan pertikel total harus diperhatikan. Terutama untuk ukuran partikel yang masuk dan ukuran partikel yang keluar tentunya juga harus dipertimbangkan(103-106). Penggunaan grinding melalui proses basah mempunyai beberapa keunggulan dibandingkan melalui proses kering diantaranya berupa ruang yang dibutuhkan lebih sedikit, daya yang diperlukan cenderung lebih kecil dalam perton materialnya, serta grinding secara basah tidak memerlukan peralatan pengontrol debu. Teknik grinding memiliki beberapa kelemahan dimana memungkinkan terjadinya korosi akibat proses basah. Faktor lain juga disebabkan akibat kadar air yang rendah sangat dibutuhkan untuk grinding, maka akan diperlukan proses pengeringan(107111).

Mekanisme kerja dari teknik grinding melibatkan gaya-gaya yang pada dasarnya akan memecah material dalam media grinding berupa silinder berputar. Gaya-gaya tersebut antara lain berupa impak atau penekanan, Chipping, dan Abrasi.

a. Impak atau penekanan, dimana gaya diberikan hampir ke seluruh permukaan partikel.

b. Chipping, dimana gaya memiliki sudut tertentu.

c. Abrasi (gesek), dimana gaya paralel terhadap permukaan partikel(112;113).

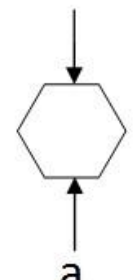

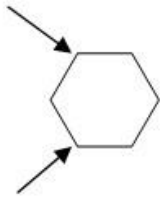

b

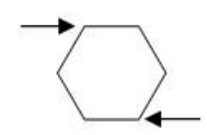

C

(114)Gambar 1. Gaya-gaya yang bekerja pada proses grinding (a) impak (compression) (b) chipping (c) abrasi

Grinding dapat bekerja melalui bantuan media yang disebut media grinding(115; 116). Media grinding adalah media yang dapat digunakan dalam menunjang proses penggerusan bahan galian dalam proses comminution(117-120). Media yang digunakan memiliki kriteria yaitu kekerasan yang tergantung kepada bahan galian yang akan direduksi ukurannya. Media grinding terdiri antara lain :

a. Silinder/ batang (rods) baja, dengan ukuran panjang hampir sama dengan panjang mill itu sendiri.

b. Bola / grinding balls, berupa bola-bola baja ataupun bahan lainnya dengan kekerasan tertentu.

c. Bijih/pebbles, yaitu media yang terbuat dari batuan keras atau bahan natural(121-123).

Untuk mendapatkan kehalusan butir yang diinginkan sesuai dengan kondisi material dan spesifikasi pengolahan pada tahap berikutnya, maka terdapat berbagai alat grinding yang dapat digunakan. Alat-alat ini bekerja dengan menggunakan prinsip tekanan gerusan yang nantinya akan melibatkan gaya-gaya impak, kompresi, robek, dan abrasi (gesek)(124; 125). Alat grinding dibedakan berdasarkan media grindingnya menjadi:

a. Batangan Silinder Baja (rod mill)

Disebut juga mesin fine crusher atau coarse grinding. Umpan yang dapat masuk berukuran $50 \mathrm{~mm}$ dan menghasilkan produk sebesar $300 \mu \mathrm{m}$. Ciri khusus dari rod mill adalah panjang shell silinder antara 1,5 sampai 2,5 kali diameternya, perbandingan ini sangat penting agar batang ( $r o d)$, yang panjangnya beberapa centimeter lebih pendek dari shell, harus dicegah dari pembengkokan agar dapat mendesak diameter silinder. Rod mill menggunakan rod selektif yang ukurannya ditentukan sehingga nantinya akan didapatkan grinding yang optimum, biasanya rod terbuat dari high carbon steel dengan diameter berukuran 25 sampai $150 \mathrm{~mm}$, semakin kecil diameter rod maka surface area (luas permukaan sentuhnya) lebih luas sehingga didapat efisiensi grinding yang lebih 
besar (126-130). Kecepatan grinding optimum biasanya pada 50-65\% kecepatan grinding kritis, namun ada beberapa dari jenis grinding menggunakan kecepatan sampai 80\% tanpa adanya catatan kegagalan aus yang berarti. Ada tiga jenis rod mill berdasarkan perbedaan pada jalur pengumpanan (opening) dan pengeluaran (discharge)(131-133).

\section{1) Center Peripheral Discharge Mill}

Umpan dimasukkan melalui trunnion pada kedua sisi mill dan pengeluaran dilakukan pada bagian bawah melalui lubang di tengah shell, mill ini bisa digunakan untuk grinding basah dan kering dan menghasilkan lebih banyak partikel kasar daripada halus.

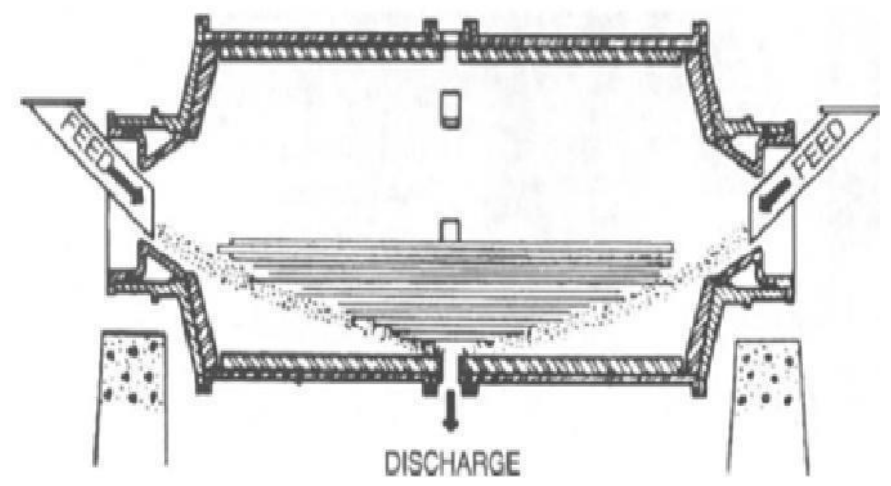

(134)Gambar 2. Center Peripheral Discharge Mill

\section{2) End Peripheral Discharge Mill}

Memiliki jalur pengumpanan pada satu sisi trunnion dan pengeluaran dilakukan pada bagian bawah shell di seberang sisi pengumpanan, biasanya digunakan untuk grinding kering dan lembab.

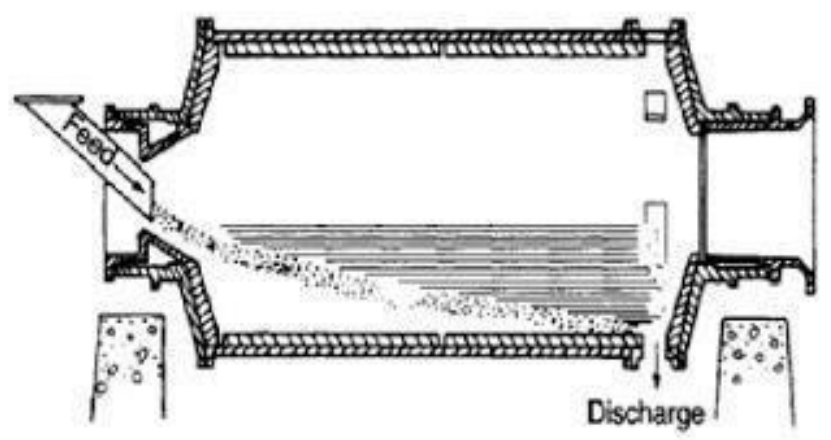

(135)Gambar 3. End Peripheral Discharge Mill

\section{3) Overflow (Trunnion) Mill}

Pengumpanan dilakukan melalui salah satu trunnion dan pengeluaran dilakukan melalui trunnion lainnya, biasanya mill ini digunakan untuk grinding basah.

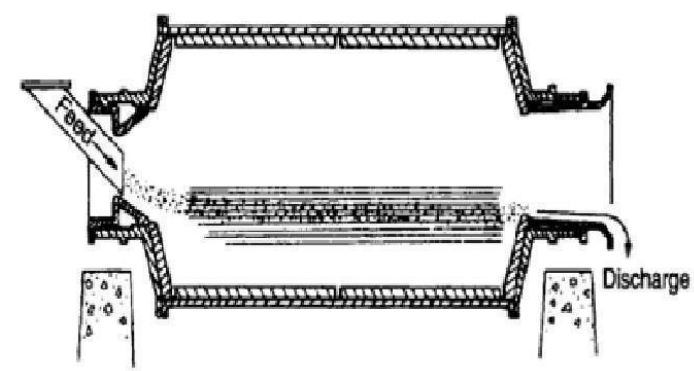

(136)Gambar 4. Overflow Mills 


\section{b. Bola-bola Baja}

Prinsip kerja alat grinding yang menggunakan media bola-bola baja adalah memutar silinder yang berisi bola-bola grinding yang terbuat dari baja dan material (bijih) di dalamnya, proses grinding terjadi dengan pergerakan bola-bola dimana balls berputar di dalam dan menggerus bijih. Semakin besar diameter silinder maka kecepatan rotasi akan semakin lambat. Jika kecepatan terlalu besar maka akan terjadi gaya sentrifugal pada silinder sehingga balls akan menempel pada tepi silinder dan proses grinding akan menjadi tidak optimum. Grinding balls biasanya terbuat dari baja, baik itu baja karbon tinggi, baja tempa, baja paduan, atau baja cor-coran dan konsumsinya berkisar antara 0.1 sampai $1.0 \mathrm{~kg}$ per ton bijih tergantung dari kekerasan bijih, kehalusan gerus, dan kualitas medium. Pengisian dilakukan sebesar 40-50\% dari volum mill, dan sekitar $40 \%$ adalah ruang kosong(137-139). Alat grinding yang menggunakan bola-bola baja sebagai media grindingnya ada 2 jenis, yaitu ball mill dan tube mill.

\section{1) Ball mill}

Ball Mill mempnyai ukuran panjang kira-kira sama dengan diameternya atau maksimal $1 \frac{1}{2} 2$ kali diameternya. Diameter mill bisa mencapai 5,5 $\mathrm{m}$ dan panjang 7,3 m. Ball mill bekerja dengan kecepatan yang lebih tinggi yaitu sekitar 70-80\% dari kecepatan kritis. Ukuran produk hasil keluaran dari ball mill sekitar $45 \mu \mathrm{m}$. Kinerja mesin ball mill dinilai berdasarkan tenaga bukan berdasarkan kapasitas, dan didorong dengan motor bertenaga sebesar $4 \mathrm{MW}$.

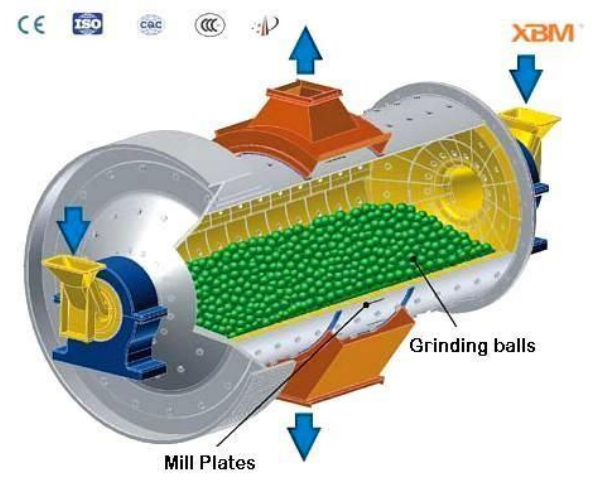

(140)Gambar 5. Ball Mill

Seperti halnya rod mill, ball mill juga diklasifikasikan berdasarkan sifat keluaran produknya:

a) Peripheral Discharge Mill umpan melewati screen sepanjang silinder, bisa digunakan pada grinding kering maupun basah.

b) Overflow Mill prinsipnya sama dengan prinsip kerja rod mill.

c) Grate Mill merupakan mill yang paling sering digunakan(141).

2) Tube Mill

Prinsipnya sama dengan ball mill, perbedaanya hanya panjangnya antara 2 kali diameternya, grinding media menggunakan bola- bola baja. Selain itu, tube mill memiliki 2 kompartmen, sehingga ukuran produk yang dihasilkan lebih halus dibandingkan ball mill yaitu $<45 \quad \mu$ m. 


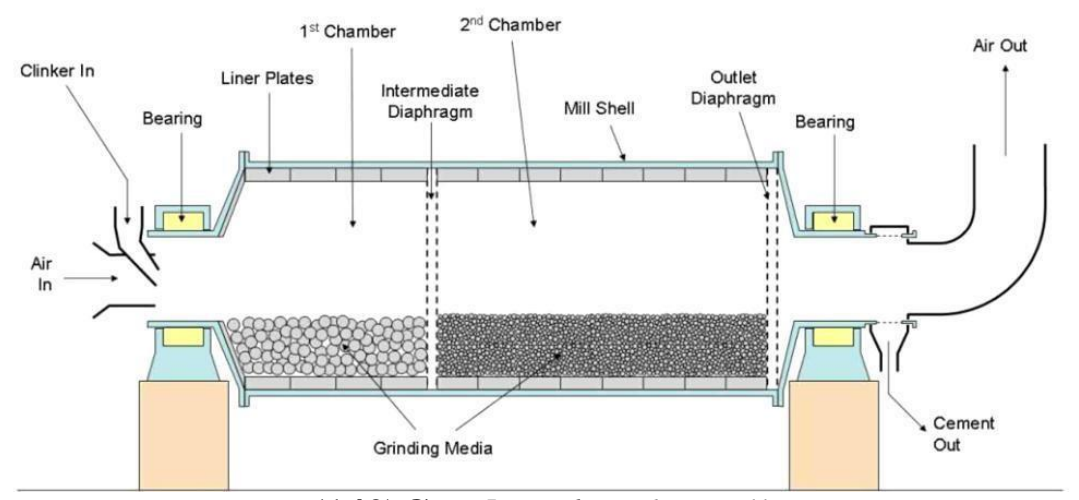

(142)Gambar 6. Tube Mill

\section{c. Pebble}

Pebble adalah media grinding berupa batuan keras atau batuan natural, dengan kata lain alat grinding yang menggunakan pebble sebagai media grindingnya menggunakan batuan yang mengandung bijih itu sendiri. Alat grinding yang menggunakan pebble sebagai media grindingnya terdiri atas semi autogenous grinding (SAG) mill, autogenous grinding mill, dan tower mill.

\section{1) Semi Autogenous Grinding (SAG) Mill}

Semi Autogenous Grinding (SAG) mill adalah peralatan / sirkuit grinding yang paling sering diminati dibandingkan dengan sirkuit konvensional dikarenakan memiliki beberapa keuntungan-keuntungan, seperti biaya yang lebih rendah, kemampuan menangani material basah dan lengket, flowsheet yang lebih sederhana, peralatan berukuran besar, kebutuhan operator yang sedikit, dan konsumsi medium grinding yang sedikit. SAG mill menggunakan metode grinding dengan kombinasi medium grinding dan partikel bijih itu sendiri $(143 ; 144)$. Berdasarkan data riset yang ada, $S A G$ mill dengan balls sebagai medium terbukti paling efektif pada 6-10\% volum mill. Untuk mengendalikan sirkuit grinding diperlukan beberapa variabel yang harus diketahui antara lain :

a) Perubahan laju umpan baru dan circulating load.

b) Distribusi ukuran dan kekerasan bijih.

c) Laju penambahan air pada sirkuit.

d) Interupsi operasi dalam sirkuit, seperti pemberhentian karena pengumpanan media grinding baru atau pembersihan choke cyclone(145).

\section{2) Autogenous Grinding Mill}

Prinsip kerja autogenous grinding mill sama dengan dengan prinsip kerja semi autogenous grinding mill, hanya saja autogenous mill bekerja berdasarkan metode grinding yang hanya menggunakan partikelpartikel bijih itu sendiri sebagai media untuk melakukan kominusi(146).

3) Tower Mill

Tower mill digunakan untuk operasi penggerusan yang sangat halus, ruang dimana terjadi pengerusan / grinding bentuknya vertikal dan bagian dalamnya dilengkapi dengan alat yang melingkar berbentuk spiral dari atas ke bawah yang dapat memberikan gerakan melingkar terhadap grinding media yang turun ke bawah. Umpan beserta air dimasukkan dari bagian atas kemudian batuan mineral menggelundung kebawah diatas pelat yang melingkar. Prinsip kerja dari tower mill adalah dengan memberikan tekanan pada batuan yang ada di dalamnya. Saat alat yang berbentuk spiral yang berada didalam tower mill berputar maka batuan akan jatuh kebawah dan akan mendesak batuan sampai batuan tersebut hancur. 


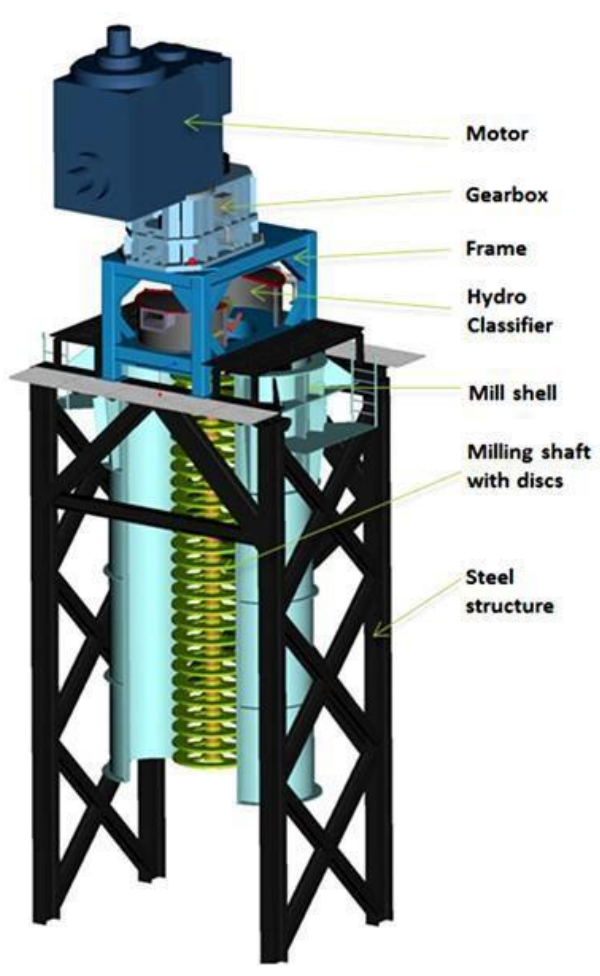

(147; 148)Gambar 7. Tower Mill

\section{Kesimpulan}

Berdasarkan pembahasan Grinding merupakna suatu alat yang digunakan dalam pengolahan bahan galian industri. Tujuan teknik grinding ini untuk mendapatkan material dengan ukuran yang lebih kecil dari ukuran sebelumnya. Penggunaan grinding dilakukan pada material basah. Proses kerja grinding melibatkan gaya-gaya yang bekerja untuk memecah material, sehingga menghasilkan material dengan ukuran yang lebih kecil. Teknik grinding memiliki kelemahan dimana memungkinkan terjadinya korosi akibat proses dilakukan dalam keadaan basah (wet condition).

Berdasarkan pembahasan pada bab sebelumnya, dapat disimpulkan beberapa hal:

a. Grinding merupakan proses terakhir dari comminution dimana proses kerjanya menggunakan prinsip gabungan dari impak (tumbukan) dan abrasi. Pada proses grinding partikel atau material direduksi dari $5-250 \mathrm{~mm}$ menjadi $10-300 \mu \mathrm{m}$.

b. Media yang digunakan dalam proses grinding antara lain:

1) Batangan Silinder (rods) baja, dengan ukuran panjang hampir sama dengan panjang mill itu sendiri.

2) Bola / grinding balls, berupa bola-bola baja ataupun bahan lainnya dengan kekerasan tertentu.

3) Bijih / pebbles, yaitu media yang terbuat dari batuan keras atau bahan natural.

c. Alat-alat grinding berdasarkan media grindingnya diklasifikasikan menjadi:

1) Batangan silinder baja : Rod Mill

2) Bola baja : Ball Mill dan Tube Mill

3) Pebble : Semi Autogenus Mill, Autogenus Mill dan Tower Mill 


\section{References}

1. Shi H, Zhang S, Zhu X, Liu Y, Wang T, et al. 2017. Uniform Gold-NanoparticleDecorated \{001\}-Faceted Anatase TiO2 Nanosheets for Enhanced Solar-Light Photocatalytic Reactions. ACS applied materials \& interfaces 9:36907-16

2. Scherrer SS, Lohbauer U, Della Bona A, Vichi A, Tholey MJ, et al. 2017. ADM guidance-Ceramics: guidance to the use of fractography in failure analysis of brittle materials. Dental materials : official publication of the Academy of Dental Materials 33:599-620

3. Saubade F, Hemery YM, Rochette I, Guyot JP, Humblot C. 2018. Influence of fermentation and other processing steps on the folate content of a traditional African cereal-based fermented food. International journal of food microbiology 266:79-86

4. Singh P, Kumar A, Shekhawat V. 2017. Scarf-related injuries at a major trauma center in northern India. Chinese journal of traumatology $=$ Zhonghua chuang shang za zhi 20:90-3

5. Siewert C, Moog R, Alex R, Kretzer P, Rothenhausler B. 2018. Process and scaling parameters for wet media milling in early phase drug development: A knowledge based approach. European journal of pharmaceutical sciences : official journal of the European Federation for Pharmaceutical Sciences 115:126-31

6. Smrke S, Wellinger M, Suzuki T, Balsiger F, Opitz SEW, Yeretzian C. 2018. TimeResolved Gravimetric Method To Assess Degassing of Roasted Coffee. Journal of agricultural and food chemistry 66:5293-300

7. Svihus B, Itani K, Borg K, Larsson EC, Ao R, et al. 2017. Performance and digestive function of broiler chickens given grit in the diet. British poultry science 58:530-5

8. Suzuki N, Kawahata M, Yamaguchi K, Suzuki T, Tomono K, Fukami T. 2018. Comparison of the relative stability of pharmaceutical cocrystals consisting of paracetamol and dicarboxylic acids. Drug development and industrial pharmacy 44:582-9

9. Sears CG, Zierold KM. 2017. Health of Children Living Near Coal Ash. Global pediatric health 4:2333794X17720330

10. Strukil V. 2017. Mechanochemical synthesis of thioureas, ureas and guanidines. Beilstein journal of organic chemistry 13:1828-49

11. Moon JH, Yoon WB. 2018. Effect of moisture content and particle size on grinding kinetics and flowability of balloon flower (Platycodon grandiflorum). Food science and biotechnology 27:641-50

12. Ordoudi SA, Staikidou C, Kyriakoudi A, Tsimidou MZ. 2018. A stepwise approach for the detection of carminic acid in saffron with regard to religious food certification. Food chemistry 267:410-9

13. Li Y, Wang H, Cui W, Li C, Zhou P, Zhang Y. 2017. [Application of ultrasonic bone curette in posterior cervical single open-door laminoplasty]. Zhongguo xiu fu chong jian wai ke za zhi = Zhongguo xiufu chongjian waike zazhi $=$ Chinese journal of reparative and reconstructive surgery 31:683-9

14. Hu X, Zhang Q, Ning J, Wu W, Li C. 2018. Study of Two-Body Wear Performance of Dental Materials. Journal of the National Medical Association 110:250-5

15. Ioannou M, Delimitis A, Symeou E, Giapintzakis J, Kyratsi T. 2017. Effect of Silicon Nitride/Oxide on the Structure and the Thermal Conductivity of CoSi Nanocomposites. Journal of nanoscience and nanotechnology 17:1555-563

16. Seki T, Kobayashi K, Ito H. 2017. Low-temperature-selective luminescent mechanochromism of a thienyl gold isocyanide complex. Chemical communications 53:6700-3 
17. Siegert W, Ganzer C, Kluth H, Rodehutscord M. 2018. Effect of particle size distribution of maize and soybean meal on the precaecal amino acid digestibility in broiler chickens. British poultry science 59:68-75

18. Saruhanoglu A, Gokcen-Rohlig B, Saruhanoglu C, Ongul D, Koray M. 2017. Frequency of temporomandibular disorder signs and symptoms among call center employees. Cranio : the journal of craniomandibular practice 35:244-9

19. Shi W, Yu J, Jiang Z, Shao Q, Su W. 2017. Encaging palladium(0) in layered double hydroxide: A sustainable catalyst for solvent-free and ligand-free Heck reaction in a ball mill. Beilstein journal of organic chemistry 13:1661-8

20. Spampinato A, Axinte DA. 2017. On modelling the interaction between two rotating bodies with statistically distributed features: an application to dressing of grinding wheels. Proceedings. Mathematical, physical, and engineering sciences 473:20170466

21. Shieh M, Yu CC, Miu CY, Kung CH, Huang CY, et al. 2017. Semiconducting Coordination Polymers Based on the Predesigned Ternary Te-Fe-Cu Carbonyl Cluster and Conjugation-Interrupted Dipyridyl Linkers. Chemistry 23:11261-71

22. Alavi S, Kachuie M. 2017. Assessment of the hardness of different orthodontic wires and brackets produced by metal injection molding and conventional methods. Dental research journal 14:282-7

23. Al-Ghananeem AM, Leung KP, Faraj J, DeLuca PP. 2017. Development of a Sustained Antiplaque and Antimicrobial Chewing Gum of a Decapeptide. AAPS PharmSciTech 18:2240-7

24. Ali A, Ali F, Cheong WJ. 2017. Sedimentation assisted preparation of ground particles of silica monolith and their $\mathrm{C} 18$ modification resulting in a chromatographic phase of improved separation efficiency. Journal of chromatography. A 1525:79-86

25. Amaral M, Villefort RF, Melo RM, Pereira GKR, Zhang Y, et al. 2017. Fatigue limit of monolithic Y-TZP three-unit-fixed dental prostheses: Effect of grinding at the gingival zone of the connector. Journal of the mechanical behavior of biomedical materials 72:159-62

26. Arivazhagan C, Maity A, Bakthavachalam K, Jana A, Panigrahi SK, et al. 2017. Phenothiazinyl Boranes: A New Class of AIE Luminogens with Mega Stokes Shift, Mechanochromism, and Mechanoluminescence. Chemistry 23:7046-51

27. Sharma M, Das B, Sharma M, Deka BK, Park YB, et al. 2017. Pd/Cu-Oxide Nanoconjugate at Zeolite-Y Crystallite Crafting the Mesoporous Channels for Selective Oxidation of Benzyl-Alcohols. ACS applied materials \& interfaces 9:35453-62

28. Spears JW, Lloyd KE, Krafka K. 2017. Chromium concentrations in ruminant feed ingredients. Journal of dairy science 100:3584-90

29. Seki T, Tokodai N, Omagari S, Nakanishi T, Hasegawa Y, et al. 2017. Luminescent Mechanochromic 9-Anthryl Gold(I) Isocyanide Complex with an Emission Maximum at $900 \mathrm{~nm}$ after Mechanical Stimulation. Journal of the American Chemical Society 139:6514-7

30. Schendel SA. 2017. Autologous Adipose-Derived Tissue Matrix Part I: Biologic Characteristics. Aesthetic surgery journal 37:1062-8

31. Silva CT, Primo LG, Mangabeira A, Maia LC, Fonseca-Goncalves A. 2017. Homeopathic therapy for sleep bruxism in a child: Findings of a 2-year case report. Journal of the Indian Society of Pedodontics and Preventive Dentistry 35:381-3

32. Asahara M, Nishioka Y. 2017. Geographic Variation of Absolute and Relative Lower Molar Sizes in the Japanese Macaque (Macaca fuscata: Primates, Mammalia). Zoological 
33. Askew JH, Shepherd HJ. 2017. Mechanochemical synthesis of cooperative spin crossover materials. Chemical communications 54:180-3

34. Ates SM, Korkmaz FM, Caglar IS, Duymus ZY, Turgut S, Bagis EA. 2017. The effect of ultrafast fiber laser application on the bond strength of resin cement to titanium. Lasers in medical science 32:1121-9

35. Ayna M, Gulses A, Ziebart T, Neff A, Acil Y. 2017. Histopathological and microradiological features of peri-implantitis. A case report. Stomatologija 19:97-100

36. Schmalz G, Galler KM. 2017. Biocompatibility of biomaterials - Lessons learned and considerations for the design of novel materials. Dental materials : official publication of the Academy of Dental Materials 33:382-93

37. Azharshekoufeh L, Shokri J, Barzegar-Jalali M, Javadzadeh Y. 2017. Liquigroud technique: a new concept for enhancing dissolution rate of glibenclamide by combination of liquisolid and co-grinding technologies. BioImpacts : BI 7:5-12

38. Bacher J, Kaartinen T. 2017. Liberation of Printed Circuit Assembly (PCA) and dust generation in relation to mobile phone design in a size reduction process. Waste management 60:609-17

39. Bartolo D, Cassar G, Al-Haj Husain N, Ozcan M, Camilleri J. 2017. Effect of polishing procedures and hydrothermal aging on wear characteristics and phase transformation of zirconium dioxide. The Journal of prosthetic dentistry 117:545-51

40. Beatrice P, Passerini N, Trastullo R, Keiser J, Zanolla D, et al. 2017. An explorative analysis of process and formulation variables affecting comilling in a vibrational mill: The case of praziquantel. International journal of pharmaceutics 533:402-12

41. Bednarska AJ, Swiatek ZM, Paciorek K, Kubinska N. 2017. Effect of cadmium bioavailability in food on its compartmentalisation in carabids. Ecotoxicology 26:1259-70

42. Ben Amira A, Mokni A, Yaich H, Chaabouni M, Besbes S, et al. 2017. Technological properties of milk gels produced by chymosin and wild cardoon rennet optimized by response surface methodology. Food chemistry 237:150-8

43. Bertazzo-Silveira E, Stuginski-Barbosa J, Porporatti AL, Dick B, Flores-Mir C, et al. 2017. Association between signs and symptoms of bruxism and presence of tori: a systematic review. Clinical oral investigations 21:2789-99

44. Bigdeli F, Hosseini-Monfared H, Morsali A, Mayer P. 2017. Synthesis of a new $\mathrm{Hg}$ (II) coordination polymer: Ultrasonic-assisted synthesis and mechanical preparation of nanostructure. Ultrasonics sonochemistry 39:669-75

45. Boonruksa P, Bello D, Zhang J, Isaacs JA, Mead JL, Woskie SR. 2017. Exposures to nanoparticles and fibers during injection molding and recycling of carbon nanotube reinforced polycarbonate composites. Journal of exposure science \& environmental epidemiology 27:379-90

46. Borges R, Baika LM, Grassi MT, Wypych F. 2018. Mechanochemical conversion of chrysotile/K2HPO4 mixtures into potential sustainable and environmentally friendly slow-release fertilizers. Journal of environmental management 206:962-70

47. Bortoletto CC, Salgueiro M, Valio R, Fragoso YD, Motta PB, et al. 2017. The relationship between bruxism, sleep quality, and headaches in schoolchildren. Journal of physical therapy science 29:1889-92

48. Brabencova S, Ihnatova I, Potesil D, Fojtova M, Fajkus J, et al. 2017. Variations of Histone Modification Patterns: Contributions of Inter-plant Variability and Technical Factors. Frontiers in plant science 8:2084

49. Buezas G, Becerra F, Vassallo A. 2017. Cranial suture complexity in caviomorph rodents (Rodentia; Ctenohystrica). Journal of morphology 278:1125-36 
50. Cakir-Omur T, Gozneli R, Ozkan Y. 2017. Effects of Silica Coating by Physical Vapor Deposition and Repeated Firing on the Low-Temperature Degradation and Flexural Strength of a Zirconia Ceramic. Journal of prosthodontics : official journal of the American College of Prosthodontists

51. Camoin A, Tardieu C, Blanchet I, Orthlieb JD. 2017. [Sleep bruxism in children]. Archives de pediatrie : organe officiel de la Societe francaise de pediatrie 24:659-66

52. Candido LM, Fais L, Ferreira EB, Antonio SG, Pinelli L. 2017. Characterization of a Diamond Ground Y-TZP and Reversion of the Tetragonal to Monoclinic Transformation. Operative dentistry 42:407-17

53. Canossa S, Bacchi A, Graiff C, Pelagatti P, Predieri G, et al. 2017. Hierarchy of Supramolecular Arrangements and Building Blocks: Inverted Paradigm of Crystal Engineering in the Unprecedented Metal Coordination of Methylene Blue. Inorganic chemistry 56:3512-6

54. Casas GA, Huang C, Stein HH. 2017. Nutritional value of soy protein concentrate ground to different particle sizes and fed to pigs. Journal of animal science 95:827-36

55. Cezairli B, Sivrikaya EC, Omezli MM, Ayranci F, Seyhan Cezairli N. 2017. Results of Combined, Single-Session Arthrocentesis and Dextrose Prolotherapy for Symptomatic Temporomandibular Joint Syndrome: A Case Series. Journal of alternative and complementary medicine 23:771-7

56. Chadha R, Rani D, Goyal P. 2017. Supramolecular Cocrystals of Gliclazide: Synthesis, Characterization and Evaluation. Pharmaceutical research 34:552-63

57. Chakanya C, Arnaud E, Muchenje V, Hoffman LC. 2017. Colour and oxidative stability of mince produced from fresh and frozen/thawed fallow deer (Dama dama) meat. Meat science 126:63-72

58. Chang H, Mu S. 2017. Detecting the Water-soluble Chloride Distribution of Cement Paste in a High-precision Way. Journal of visualized experiments : JoVE

59. Chaturvedi M, Kumar M, Pathak K, Bhatt S, Saini V. 2017. Surface Solid Dispersion and Solid Dispersion of Meloxicam: Comparison and Product Development. Advanced pharmaceutical bulletin 7:569-77

60. Chatzopoulos GS, Sanchez M, Cisneros A, Wolff LF. 2017. Prevalence of temporomandibular symptoms and parafunctional habits in a university dental clinic and association with gender, age, and missing teeth. Cranio : the journal of craniomandibular practice: $1-9$

61. Chavali R, Lin CP, Lawson NC. 2017. Evaluation of Different Polishing Systems and Speeds for Dental Zirconia. Journal of prosthodontics : official journal of the American College of Prosthodontists 26:410-8

62. Chen F, Wang H, Tang Y, Yin S, Huang S, Zhang G. 2018. Novel cavitation fluid jet polishing process based on negative pressure effects. Ultrasonics sonochemistry 42:339-46

63. Chen HJ, Chang SN, Tang CW. 2017. Application of the Taguchi Method for Optimizing the Process Parameters of Producing Lightweight Aggregates by Incorporating Tile Grinding Sludge with Reservoir Sediments. Materials 10

64. Chen T, Zhang M, Bhandari B, Yang Z. 2018. Micronization and nanosizing of particles for an enhanced quality of food: A review. Critical reviews in food science and nutrition 58:993-1001

65. Cheng H, Hernandez JG, Bolm C. 2017. Mechanochemical Ruthenium-Catalyzed Hydroarylations of Alkynes under Ball-Milling Conditions. Organic letters 19:6284-7

66. Chi CW, Deng YL, Lee JW, Lin CP. 2017. Fracture resistance of dental nickeltitanium rotary instruments with novel surface treatment: Thin film metallic glass coating. Journal of the Formosan Medical Association = Taiwan yi zhi 116:373-9 
67. Cho JH, Kim JC, Kim HS, Kim DS, Kim KS, et al. 2017. Novel dabigatran etexilate hemisuccinate-loaded polycap: Physicochemical characterisation and in vivo evaluation in beagle dogs. International journal of pharmaceutics 525:60-70

68. Cho SH, Thompson GA. 2017. A method of facilitating the fabrication of access openings for implant-supported complete fixed dental prostheses. The Journal of prosthetic dentistry 117:814-6

69. Chogle S, Miller A, Saadoun M. 2017. Limited Evidence Suggests That Symptomatic Cracked Teeth Share Characteristics Such as Clenching, Grinding, and Molars With Distal Cracks. The journal of evidence-based dental practice 17:281-3

70. Chougule KJ, Wadkar AP. 2017. An In vitro Comparative Evaluation of Flexural Strength of Monolithic Zirconia after Surface Alteration Utilising Two Different Techniques. Journal of clinical and diagnostic research : JCDR 11:ZC20-ZC3

71. Chu C, Wei M, Wang S, Zheng L, He Z, et al. 2017. Micro-matrix solid-phase dispersion coupled with MEEKC for quantitative analysis of lignans in Schisandrae Chinensis Fructus using molecular sieve TS-1 as a sorbent. Journal of chromatography. B, Analytical technologies in the biomedical and life sciences 1063:174-9

72. Ciccoritti R, Terracciano G, Cammerata A, Sgrulletta D, Del Frate V, et al. 2018. Hydrothermal grain pre-processing and ultra-fine milling for the production of durum wheat flour fractions with high nutritional value. Food science and technology international = Ciencia y tecnologia de los alimentos internacional 24:242-50

73. Clarkson C, Jacobs Z, Marwick B, Fullagar R, Wallis L, et al. 2017. Human occupation of northern Australia by 65,000 years ago. Nature 547:306-10

74. Cousin K, Menuel S, Monflier E, Hapiot F. 2017. Hydroformylation of Alkenes in a Planetary Ball Mill: From Additive-Controlled Reactivity to Supramolecular Control of Regioselectivity. Angewandte Chemie 56:10564-8

75. Cugovcan M, Jablan J, Lovric J, Cincic D, Galic N, Jug M. 2017. Biopharmaceutical characterization of praziquantel cocrystals and cyclodextrin complexes prepared by grinding. Journal of pharmaceutical and biomedical analysis 137:42-53

76. Cumerlato M, Lima EM, Osorio LB, Mota EG, Menezes LM, Rizzatto SMD. 2017. Effect of surface treatment of prefabricated teeth on shear bond strength of orthodontic brackets. Dental press journal of orthodontics 22:47-52

77. Demir ME, Aktas Uygun D, Erdag A, Akgol S. 2017. A new support material for IgG adsorption: Syntrichia papillosissima (Copp.) Loeske. Artificial cells, nanomedicine, and biotechnology 45:1363-8

78. Deng DQ, Liu L, Yao ZL, Song KIL, Lao DZ. 2017. A practice of ultra-fine tailings disposal as filling material in a gold mine. Journal of environmental management 196:100-9

79. Deng T, Wu D, Duan C, Yan X, Du Y, et al. 2017. Spatial Profiling of Gibberellins in a Single Leaf Based on Microscale Matrix Solid-Phase Dispersion and Precolumn Derivatization Coupled with Ultraperformance Liquid Chromatography-Tandem Mass Spectrometry. Analytical chemistry 89:9537-43

80. Denton AK, Mass J, Kulahoglu C, Lercher MJ, Brautigam A, Weber AP. 2017. Freeze-quenched maize mesophyll and bundle sheath separation uncovers bias in previous tissue-specific RNA-Seq data. Journal of experimental botany 68:147-60

81. Di Mattia CD, Sacchetti G, Mastrocola D, Serafini M. 2017. From Cocoa to Chocolate: The Impact of Processing on In Vitro Antioxidant Activity and the Effects of Chocolate on Antioxidant Markers In Vivo. Frontiers in immunology 8:1207

82. Dong Z, Cheng H. 2017. Ductile mode grinding of reaction-bonded silicon carbide mirrors. 
83. Du K, Li J, Bai Y, An M, Gao XM, Chang YX. 2018. A green ionic liquid-based vortex-forced MSPD method for the simultaneous determination of 5-HMF and iridoid glycosides from Fructus Corni by ultra-high performance liquid chromatography. Food chemistry 244:190-6

84. Du K, Li J, Tian F, Chang YX. 2018. Non-ionic detergent Triton X-114 Based vortexsynchronized matrix solid-phase dispersion method for the simultaneous determination of six compounds with various polarities from Forsythiae Fructus by ultra high-performance liquid chromatography. Journal of pharmaceutical and biomedical analysis 150:59-66

85. Du S, Wang Y, Wu S, Yu B, Shi P, et al. 2017. Two novel cocrystals of lamotrigine with isomeric bipyridines and in situ monitoring of the cocrystallization. European journal of pharmaceutical sciences : official journal of the European Federation for Pharmaceutical Sciences 110:19-25

86. Dupret V, Sanchez S, Goujet D, Ahlberg PE. 2017. The internal cranial anatomy of Romundina stellina Orvig, 1975 (Vertebrata, Placodermi, Acanthothoraci) and the origin of jawed vertebrates-Anatomical atlas of a primitive gnathostome. PloS one 12:e0171241

87. Duran-Palma MH, Mendoza-Barraza SS, Magana-Vergara NE, Martinez-Martinez FJ, Gonzalez-Gonzalez JS. 2017. Crystal structure of pharmaceutical cocrystals of 2,6diaminopyridine with piracetam and theophylline. Acta crystallographica. Section $C$, Structural chemistry 73:767-72

88. Dutra D, Pereira G, Kantorski KZ, Exterkate R, Kleverlaan CJ, et al. 2017. Grinding With Diamond Burs and Hydrothermal Aging of a Y-TZP Material: Effect on the Material Surface Characteristics and Bacterial Adhesion. Operative dentistry 42:66978

89. Eder SJ, Cihak-Bayr U, Bianchi D, Feldbauer G, Betz G. 2017. Thermostat Influence on the Structural Development and Material Removal during Abrasion of Nanocrystalline Ferrite. ACS applied materials \& interfaces 9:13713-25

90. Eguaogie O, Conlon PF, Ravalico F, Sweet JS, Elder TB, et al. 2017. Nucleophilic displacement reactions of 5'-derivatised nucleosides in a vibration ball mill. Beilstein journal of organic chemistry 13:87-92

91. Elbert SM, Wagner P, Kanagasundaram T, Rominger F, Mastalerz M. 2017. Boroquinol Complexes with Fused Extended Aromatic Backbones: Synthesis and Optical Properties. Chemistry 23:935-45

92. El-Hashash MA, Gomha SM, El-Arab EE. 2017. Utility of Pyrazolylchalcone Synthon to Synthesize Azolopyrimidines under Grindstone Technology. Chemical \& pharmaceutical bulletin 65:90-6

93. Ella B, Ghorayeb I, Burbaud P, Guehl D. 2017. Bruxism in Movement Disorders: A Comprehensive Review. Journal of prosthodontics : official journal of the American College of Prosthodontists 26:599-605

94. Ella B, Guillaud E, Langbour N, Guehl D, Burbaud P. 2017. Prevalence of Bruxism in Hemifacial-Spasm Patients. Journal of prosthodontics : official journal of the American College of Prosthodontists 26:280-3

95. Elvira-Gonzalez L, Puchades AV, Carpino C, Alfaro-Fernandez A, Font-SanAmbrosio MI, et al. 2017. Fast detection of Southern tomato virus by one-step transcription loop-mediated isothermal amplification (RT-LAMP). Journal of virological methods 241:11-4

96. Fakhruddin KS, El Batawi H, Gorduysus MO. 2017. Effectiveness of audiovisual distraction with computerized delivery of anesthesia during the placement of stainless steel crowns in children with Down syndrome. European journal of dentistry 11:1-5 
97. Fatemi F, Djahaniani H, Mohtat B. 2017. Three-Component Reaction of Benzothiazole, Acetylenic Esters, Phenoles; Synthesis of Dialkyl 2-benzo[d]thiazol Derivatives Under Grinding. Combinatorial chemistry \& high throughput screening 20:338-45

98. Felix S, Araujo J, Pires AM, Sousa AC. 2017. Soap production: A green prospective. Waste management 66:190-5

99. Fernandez-Gonzalez FJ, Cabero-Lopez J, Brizuela A, Suazo I, Perez-Pevida E, et al. 2017. Efficacy of Selective Grinding Guided by an Occlusal Splint in Management of Myofascial Pain: A Prospective Clinical Trial. The open dentistry journal 11:301-11

100. Fialova D, Skoupy R, Drozdova E, Patak A, Pinos J, et al. 2017. The Application of Scanning Electron Microscopy with Energy-Dispersive X-Ray Spectroscopy (SEMEDX) in Ancient Dental Calculus for the Reconstruction of Human Habits. Microscopy and microanalysis : the official journal of Microscopy Society of America, Microbeam Analysis Society, Microscopical Society of Canada 23:1207-13

101. Fohler M, Frommel S, Schneider M, Pfau B, Gunther CM, et al. 2017. A general approach to obtain soft $\mathrm{x}$-ray transparency for thin films grown on bulk substrates. The Review of scientific instruments 88:103701

102. Fotschki B, Juskiewicz J, Jurgonski A, Rigby N, Sojka M, et al. 2017. Raspberry pomace alters cecal microbial activity and reduces secondary bile acids in rats fed a high-fat diet. The Journal of nutritional biochemistry 46:13-20

103. Fritz RD, Chen Y, Contreras V. 2017. Gluten-containing grains skew gluten assessment in oats due to sample grind non-homogeneity. Food chemistry 216:170-5

104. Fuentes AD, Sforza C, Miralles R, Ferreira CL, Mapelli A, et al. 2017. Assessment of electromyographic activity in patients with temporomandibular disorders and natural mediotrusive occlusal contact during chewing and tooth grinding. Cranio : the journal of craniomandibular practice 35:152-61

105. Fumic B, Jablan J, Cincic D, Zovko Koncic M, Jug M. 2018. Cyclodextrin encapsulation of daidzein and genistein by grinding: implication on the glycosaminoglycan accumulation in mucopolysaccharidosis type II and III fibroblasts. Journal of microencapsulation 35:1-12

106. Gallegos D, Wedwitschka H, Moeller L, Zehnsdorf A, Stinner W. 2017. Effect of particle size reduction and ensiling fermentation on biogas formation and silage quality of wheat straw. Bioresource technology 245:216-24

107. Gao H, Song Z, Zhang W, Yang X, Wang X, Wang D. 2017. Synthesis of highly effective absorbents with waste quenching blast furnace slag to remove Methyl Orange from aqueous solution. Journal of environmental sciences 53:68-77

108. Gautam P, Yu CP, Zhang G, Hillier VE, Chan JMW. 2017. Pulling with the Pentafluorosulfanyl Acceptor in Push-Pull Dyes. The Journal of organic chemistry 82:11008-20

109. Gawedzinski J, Pawlowski ME, Tkaczyk TS. 2017. Quantitative evaluation of performance of 3D printed lenses. Optical engineering 56

110. Gerhard C, Tasche D, Uteza O, Hermann J. 2017. Investigation of nonuniform surface properties of classically manufactured fused silica windows. Applied optics 56:742734

111. Ghavimi H, Darvishi S, Ghanbarzadeh S. 2018. Attenuation of Morphine-Induced Tolerance and Dependence by Pretreatment with Cerebrolysin in Male rats. Drug research 68:33-7

112. Gikanga B, Eisner DR, Ovadia R, Day ES, Stauch OB, Maa YF. 2017. Processing Impact on Monoclonal Antibody Drug Products: Protein Subvisible Particulate 
Formation Induced by Grinding Stress. PDA journal of pharmaceutical science and technology 71:172-88

113. Gikanga B, Hui A, Maa YF. 2018. Mechanistic Investigation on Grinding-Induced Subvisible Particle Formation during Mixing and Filling of Monoclonal Antibody Formulations. PDA journal of pharmaceutical science and technology 72:117-33

114. Gong C, Jiang X. 2017. Characterizing Salmonella Contamination in Two Rendering Processing Plants. Journal of food protection 80:265-70

115. Grobet P, Gilon Y, Bruwier A, Nizet JL. 2017. [Sleep bruxism : state of the art and management]. Revue medicale de Liege 72:410-5

116. Groever B, Chen WT, Capasso F. 2017. Meta-Lens Doublet in the Visible Region. Nano letters 17:4902-7

117. Guilardi LF, Pereira GKR, Gundel A, Rippe MP, Valandro LF. 2017. Surface micromorphology, phase transformation, and mechanical reliability of ground and aged monolithic zirconia ceramic. Journal of the mechanical behavior of biomedical materials 65:849-56

118. Guillemot M, Oury B, Melin S. 2017. Identifying thermal breakdown products of thermoplastics. Journal of occupational and environmental hygiene 14:551-61

119. Guo C, Zhu X. 2018. Effect of ultrasound on dynamics characteristic of the cavitation bubble in grinding fluids during honing process. Ultrasonics 84:13-24

120. Guo L, Kang L, Liu X, Lin X, Di D, et al. 2017. A novel nanosuspension of andrographolide: Preparation, characterization and passive liver target evaluation in rats. European journal of pharmaceutical sciences : official journal of the European Federation for Pharmaceutical Sciences 104:13-22

121. Gupta R, Ali R, Verma S, Joshi K, Dhyani M, et al. 2017. Study of Sleep Disorders among Young Children Using Hindi Translated and Validated Version of Pediatric Sleep Questionnaire. Journal of neurosciences in rural practice 8:165-9

122. Hackenberg S, Leitner T, Jekle M, Becker T. 2018. Maltose formation in wheat dough depending on mechanical starch modification and dough hydration. Carbohydrate polymers $185: 153-8$

123. Han SH, Park K, Kim EY, Ahn SH, Lee HS, Suh HJ. 2017. Cactus (Opuntia humifusa) water extract ameliorates loperamide-induced constipation in rats. $B M C$ complementary and alternative medicine 17:49

124. Hasa D, Jones W. 2017. Screening for new pharmaceutical solid forms using mechanochemistry: A practical guide. Advanced drug delivery reviews 117:147-61

125. Hatanaka GR, Polli GS, Fais LMG, Reis J, Pinelli LAP. 2017. Zirconia changes after grinding and regeneration firing. The Journal of prosthetic dentistry 118:61-8

126. Henrion M, Servaes M, Thielecke F, Fogliano V. 2018. Application of the QUENCHER methodology to the food industry. Food chemistry 240:951-8

127. Hernandez JG. 2017. Mechanochemical borylation of aryldiazonium salts; merging light and ball milling. Beilstein journal of organic chemistry 13:1463-9

128. Hernandez JG, Bolm C. 2017. Altering Product Selectivity by Mechanochemistry. The Journal of organic chemistry 82:4007-19

129. Herrera J, Saldana B, Guzman P, Camara L, Mateos GG. 2017. Influence of particle size of the main cereal of the diet on egg production, gastrointestinal tract traits, and body measurements of brown laying hens 1 . Poultry science 96:440-8

130. Hideno A. 2017. Short-time alkaline peroxide pretreatment for rapid pulping and efficient enzymatic hydrolysis of rice straw. Bioresource technology 230:140-2

131. Hiebert BM, Abramovitch K, Rice D, Torabinejad M. 2017. Prevalence of Second Mesiobuccal Canals in Maxillary First Molars Detected Using Cone-beam Computed 
Tomography, Direct Occlusal Access, and Coronal Plane Grinding. Journal of endodontics 43:1711-5

132. Hilton TJ, Funkhouser E, Ferracane JL, Gilbert GH, Baltuck C, et al. 2017. Correlation between symptoms and external characteristics of cracked teeth: Findings from The National Dental Practice-Based Research Network. Journal of the American Dental Association 148:246-56 e1

133. Hirai Y, Nakanishi T, Kitagawa Y, Fushimi K, Seki T, et al. 2017. Triboluminescence of Lanthanide Coordination Polymers with Face-to-Face Arranged Substituents. Angewandte Chemie 56:7171-5

134. Marshansky S, Mayer P, Rizzo D, Baltzan M, Denis R, Lavigne GJ. 2018. Sleep, chronic pain, and opioid risk for apnea. Progress in neuro-psychopharmacology \& biological psychiatry 87:234-44

135. Martinez-Martin P, Manuel Rojo-Abuin J, Rizos A, Rodriguez-Blazquez C, Trenkwalder C, et al. 2017. Distribution and impact on quality of life of the pain modalities assessed by the King's Parkinson's disease pain scale. NPJ Parkinson's disease 3:8

136. Martin-Ramos P, Carrion-Prieto P, Sanchez-Bascones M, Ruiz-Potosme NM, MartinGil J. 2018. On the composition of gastroliths from broiler breeders. Journal of animal physiology and animal nutrition 102:e504-e8

137. Mascitti A, Lupacchini M, Guerra R, Taydakov I, Tonucci L, et al. 2017. Poly(ethylene glycol)s as grinding additives in the mechanochemical preparation of highly functionalized 3,5-disubstituted hydantoins. Beilstein journal of organic chemistry 13:19-25

138. Mathew T, Venkatesh S, Srinivas M. 2017. The approach and management of bruxism in Alzheimer's disease: An under-recognized habit that concerns caregivers (innovative practice). Dementia:1471301217694249

139. Matsumoto A, Jono K, Akita M, Yoshizawa M. 2017. Side-Chain-Directed Dispersion of MoS2 Nanosheets by V-Shaped Polyaromatic Compounds. Chemistry, an Asian journal 12:2889-93

140. Matsuno K, Nohara K, Fukatsu H, Tanaka N, Fujii N, et al. 2017. Videoendoscopic evaluation of food bolus preparation: A comparison between normal adult dentates and older adult dentates. Geriatrics \& gerontology international 17:226-31

141. Matsushita T, Oka S, Araki D, Nishida K, Tanaka T, et al. 2017. Patient-based outcomes after medial patellofemoral ligament reconstruction. International orthopaedics 41:1147-53

142. McCoy MJ, Hoppe Parr KA, Anderson KE, Cornish J, Haapala M, Greivell J. 2017. Diacetyl and 2,3-pentanedione in breathing zone and area air during large-scale commercial coffee roasting, blending and grinding processes. Toxicology reports 4:113-22

143. McLean D, Glass B, t Mannetje A, Douwes J. 2017. Exposure to respirable crystalline silica in the construction industry-do we have a problem? The New Zealand medical journal 130:78-82

144. McMurphy A, Xu X, Fournier S, Cehreli ZC, Sherman K, et al. 2017. Effect of Cured Versus Uncured Adhesive Inclusion on the Microtensile Bond Strength of Sealants. Journal of dentistry for children 84:58-64

145. Meng Q, Fan H, Chen F, Xiao T, Zhang L. 2018. Preparation and characterization of Dendrobium officinale powders through superfine grinding. Journal of the science of food and agriculture 98:1906-13 
146. Mesko ME, Hutton B, Skupien JA, Sarkis-Onofre R, Moher D, Pereira-Cenci T. 2017. Therapies for bruxism: a systematic review and network meta-analysis (protocol). Systematic reviews 6:4

147. Mesmar S, Ruse ND. 2017. Interfacial Fracture Toughness of Adhesive Resin Cement-Lithium-Disilicate/Resin-Composite Blocks. Journal of prosthodontics : official journal of the American College of Prosthodontists

148. Mewes D, Adler C. 2017. Safety of stationary grinding machines - impact resistance of work zone enclosures. International journal of occupational safety and ergonomics $\therefore$ JOSE 23:360-5

149 Zainul, Rahadian [et.al] (2015) Design of Photovoltaic Cell with Copper Oxide Electrode by Using Indoor Lights. Research Journal of Pharmaceutical, Biological and Chemical Sciences, 6 (4). pp. 353-361. ISSN 0975-8585

150 M., Yani, S. R., \& Zainul, R. (2017, September 4). Aktivasi Tanah Napa dan Pengaruhnya Terhadap Adsorpsi Ion Timbal (II)/ $\mathrm{Pb} 2+$. https://doi.org/10.31227/osf.io/ps523

151 Zainul, R., Oktavia, B., Dewata, I., \& efendi, j. (2017, February 4). Studi Dinamika Molekular dan Kinetika Reaksi pada Pembelahan Molekul Air untuk Produksi Gas Hidrogen. https://doi.org/10.31227/osf.io/876s3

152 Zainul, R., \& Dewata, I. (2015, December 29). Determination of pH-BOD-COD and degradation in batang arau watersheds at Padang city. https://doi.org/10.31227/osf.io/efdzi

153 Zainul, R. (2016, September 24). Determination of the half-life and the quantum yield of $\mathrm{ZnO}$ semiconductor photocatalyst in humic acid. https://doi.org/10.31227/osf.io/e8a9x

154 Zainul, R. (2016, December 18). Design and Modification of Copper Oxide Electrodes for Improving Conversion Coefficient Indoors Lights (PV-Cell) Photocells. https://doi.org/10.31227/osf.io/pgn84

155 Zainul, R. (2016, November 19). Effect of Temperature and Particle Motion against the ability of $\mathrm{ZnO}$ Semiconductor Photocatalyst in Humic Acid. https://doi.org/10.31227/osf.io/wnygb

156 Zainul, R., Alif, A., Aziz, H., Arief, S., \& s. (2015, October 22). Photoelectrosplitting Water Mechanism at Carbon Electrode Surface using Indoor lights. https://doi.org/10.31227/osf.io/vcxq8

157 H., Sanjaya, H., \& Zainul, R. (2016, August 30). Synthesis and Electrical Properties of ZnO-ITO and Al-ITO thin Film by Spin Coating Technique Through Sol Gel Process. https://doi.org/10.31227/osf.io/unrt4

158 Anhar, A., Sumarmin, R., \& Zainul, R. (2016, August 30). Measurement of Glycemic Index of West Sumatera Local Rice Genotypes for Healthy Food Selection. https://doi.org/10.31227/osf.io/tgy8h

159 M., Sanjaya, H., \& Zainul, R. (2015, December 30). Characterization of napa soil and adsorption of $\mathrm{Pb}$ (II) from aqueous solutions using on column method. https://doi.org/10.31227/osf.io/t8fh9

160 chaidir, Z., Fadjria, N., A., \& Zaimut, R. (2016, December 5). Isolation And Molecular Identification Of Freshwater Microalgae In Maninjau Lake West Sumatera. https://doi.org/10.31227/osf.io/nbcuf

161 ehaidir, z., Zainul, R., Nurakhbari, D., \& Salim, M. (2016, September 24). Optimization of Spirulina Platensis Culture for Antioxidant Production. https://doi.org/10.17605/OSF.IO/FD6E4

162 Mardi, M., Deyndha, D., Zainul, R., \& Zalmi, R. (2018). Characterization of PCC Cement by Addition of Napa Soil from Subdistrict Sarilamak 50 Kota District as 
Alternative Additional Material for Semen Padang. https://doi.org/10.1088/1757899X/335/1/012034

163 Zainul, R., Oktavia, B., Dewata, I., Efendi, J. Thermal and Surface Evaluation on The Process of Forming a $\mathrm{Cu} 2 \mathrm{O} / \mathrm{CuO}$ Semiconductor Photocatalyst on a Thin Copper Plate. https://doi.org/10.1088/1757-899X/335/1/0120349

164 Zainul, R., Alif, A., Aziz, H., Arief, S., \& Yasthopi, A. (2015). Photoelectrospliting Water for Hydrogen Production Using Illumination of Indoor Lights. Journal of Chemical and Pharmaceutical Research, 7 (9S) : 246-256. ISSN : 0975-7384

165 Zainul, Rahadian [et.al] (2015) Desain Geometri Reaktor Fotosel Cahaya Ruang. In: Peran Kimia untuk Meningkatkan Mutu Kehidupan dan Lingkungan, 18 September 2015, Padang.

166 Zainul, R., Alif, A., Aziz, H., Arief, S., \& Darajat, S. (2015, Juli). Modifikasi dan Karakterisasi I-V Sel Fotovoltaik $\mathrm{Cu}_{2} \mathrm{O} / \mathrm{Cu}-\mathrm{Gel} \mathrm{Na}_{2} \mathrm{SO}_{4}$ Melalui Iluminasi Lampu Neon. Juli 2015, Padang.

167 Zainul, R. (2015). Disain dan Modifikasi Kolektor dan Reflektor Cahaya pada Panel Sel Surya $\mathrm{Al} / \mathrm{Cu}_{2} \mathrm{O}-\mathrm{Gel} \mathrm{Na} \mathrm{SO}_{4}$

168 Zainul, Rahadian [et.al] (2015) Study of Pb(II) Biosorption from Aqueous Solution Using Immobilized Spirogyra Subsalsa Biomass. Journal of Chemical and Pharmaceutical Research, 11 (7). pp. 715-722. ISSN 0975-7384

169 Kurniawati, D., Lestari, I., Harmiwati., Sy, S., Chaidir, Z., Munaf, E., Zein, R., Aziz, H., \& Zainul, R. (2015). Biosorption of Pb (II) from Aqueous Solutions Using Column Method by Lengkeng (Euphoria Loogan Lour) Seed and Shell. Journal of Chemical and Pharmaceutical Research, 7(12) : 872-877. ISSN : 0975-7384 


\title{
Pemanfaatan Teknologi Sonikasi
}

Dini Candani ${ }^{* 1}$ Masita Ulfah ${ }^{* 2}$ Winda Noviana $^{* 3}$ dan Rahadian Zainul ${ }^{* 4}$

${ }^{1}$ Chemistry Education, FMIPA, Universitas Negeri Padang, Indonesia

${ }^{2}$ Chemistry Education, FMIPA, Universitas Negeri Padang, Indonesia

${ }^{3}$ Chemistry Education, FMIPA, Universitas Negeri Padang, Indonesia

${ }^{4}$ Physical Chemistry Laboratory, FMIPA, Universitas Negeri Padang, Indonesia

*Email:Candanidini19@gmail.com,Masitaulfah09@gmail.com,windanoviana23@g mail.com

\begin{abstract}
Abstrak:Sonikasi merupakan teknologi yang memanfaatkan gelombang ultrasonik. Ultrasonik adalah suara atau getaran dengan frekuensi yang terlalu tinggi untuk bisa didengar oleh manusia, yaitu kira-kira di atas $20 \mathrm{kHz}$. Review ini bertujuan untuk mengetahui pemanfaatan teknologi sonikasi dalam berbagai bidang. Hasil menunjukkan bahwa teknologi telah digunakan pada berbagai bidang seperti:industri, kesehatan, biologi, kimia, dan fisika.
\end{abstract}

\section{Keyword: sonikasi, ultrasonik, gelombang}

\section{Pendahuluan}

Perkembangan teknologi saat ini sangat berpengaruh terhadap kehidupan manusia. Berbagai macam teknologi telah dimanfaatkan oleh manusia untuk membantu kegiatan seperti alat kesehatan, alat rumah tangga, alat perkantoran, industri dan sebagainya. Berbagai alat elektronik tersebut sudah menggunakan peralatan yang canggih, mudah dioperasikan dan dapat beroperasi lebih cepat dari kemampuan manusia. Salah satu alat elektronik yang dimunculkan yaitu sebuah sensor yang digunakan di sebuah alat elektronik seperti robot dengan menggunakan sensor jarak, yaitu sensor ultrasonik (26)yang dikenal dengan sonikasi. 
Sonikasi merupakan aplikasi penggunaan energi suara untuk proses pengadukan partikel padasuatu sampel dengan tujuan bermacam-macam. Sonikasi menggunakan energi suara untuk menggerakkan partikel yang bearada dalam suatu sampel untuk berbagai keperluan seperti ekstraksi beberapa senyawa dari tanaman, mikroalga dan rumput laut(27). Sonikasi dapat digunakan untuk mempercepat proses pelarutan suatu materi dengan prinsip pemecahan reaksi intermolekuler, sehingga terbentuk suatu partikel yang berukuran nano(28).Sonikasi berarti pemberian perlakuan ultrasonik suatu bahan pada kondisi tertentu, sehingga menyebabkan bahan tersebut mengalami reaksi kimia sebagai akibat perlakuan teyang diberikan. Prosesnya dengan menggunakan gelombang ultrasonik pada rentang frekuensi 20 $\mathrm{KHz}-10 \mathrm{MHz}$ atau yang dikenal dengan istilah ultrasonikasi.

Sonikasi memiliki banyak efek, baik kimia maupun fisik.Efek kimia dari berkaitan dengan pemahaman efek gelombang sonik pada sistem kimia, ini disebut sonochemistry(29). Efek kimia dari (ultrasound) tidak berasal dari interaksi langsung dengan spesies molekuler. Penelitian menunjukkan bahwa tidak ada kopling langsung dari bidang akustik dengn spesies kimia pada tingkat molekuler dapat menjelaskan sonokimia(30). Sonikasi dapat digunakan untuk produksi nanopartikel, seperti nano emulsi (31), nanokristal(32), liposom dan emulsi lilin, serta untuk pemurnian air limbah, degassing, ekstraksi polisakarida rumput laut(27) minyak nabati, ekstraksi antosianin dan antioksidan(33), produksi biofuel(34), desulfurisasi minyak mentah(35), gangguan sel, polimer dan pengolahan epoksi(36), dan perekat menipis. Proses sonikasi diterapkan dalam farmasi, makanan, kosmetik, air, pelapis, tinta, cat, pengerjaan logam, perawatan kayu, pengerjaan logam(37), nanokomposit, pestisida, bahan bakar, produk kayu dan banyak industri lainnya. Sonikasi juga dapat digunakan untuk mempercepat pembubaran, dengan cara memecah interaksi antarmolekul serta menganalisis dinamika molekular dan kinetika reaksi pada pembelahan molekul(38).Ini sangat berguna ketika tidak memungkinkan untuk mengaduk sampel, seperti tabung NMRdan juga dapat digunakan sebagai penyedia energi(39) untuk melanjutkan reaksi kimia tertentu.Sonikasi juga dapat digunakan 
untuk menghilangkan gas-gas terlarut dari cairan (degassing) dengan carasonicating cairan saat berada di bawah ruang yang hampa udara. Hal tersebut merupakan alternative dari metode pembekuan dan peleburan.

Aplikasi di bidang biologi, sonikasi cukup untuk mengganggu atau menonaktifkan bahan-bahan biologis.Sebagai contoh, sonikasi sering digunakan untuk mengganggu membran sel dan melepaskan konten seluler.Proses ini disebut sonoporation kecil unilamellar vesikel (SUV) dan dapat dibuat oleh sonikasi dari suatu dispersi vesikel multilamellar besar (LMVs).Sonikasi juga digunakan untuk memfragmentasi molekul DNA, di mana DNA yang mengalami periode singkat disonikasi dan dicukur menjadi fragmen-fragmen yang lebih kecil. Pada umumnya sonikasi digunakan dalam nano teknologi untuk nano partikel merata dalam cairan dan juga digunakan untuk memecah agregat partikel koloid berukuran mikro(40). Sonikasi juga dapat digunakan untuk memulai proses kristalisasi dan bahkan mengontrol kristalisasi polimorfik.lni digunakan sebagai campur tangan dalam presipitat anti-pelarut (kristalisasi) untuk membantu pencampuran dan mengisolasi kristal kecil. Sonikasi adalah mekanisme yang digunakan dalam pembersihan ultrasonik untuk memilih partikel man yangmelekat pada permukaan. Selain aplikasi ilmu laboratorium, sonikasi juga digunakan membersihkan benda-benda seperti kacamata dan perhiasan. Sonikasi juga digunakan pada industri makanan.Aplikasi utamanya adalah dispersi untuk menghemat emulgator mahal (mayones) atau untuk mempercepat proses penyaringan (minyak nabati) dll. Percobaan dengan sonifikasi untuk pembuatan cairan dan minuman beralkohol lainnya juga telah dilakukan. Pada sampel tanah digunakan untuk memecah agregat tanah yang memungkinkan studi tentang konstituen yang berbeda dari agregat tanah (terutama bahan organik tanah ) tanpa memberikan perlakuan kimia yang keras.

Metode sonikasi termasuk jenis metode top down dalam pembuatan material nano. Gelombang tersebut ditembakkan ke dalam medium cair sehingga menghasilkan gelembung kavitasi yang dapat menyebabkan partikel memiliki diameter dalam skala nano(41). 
Gelombang ultrasonik merupakan gelombang mekanik longitudinal yang tidak dapat didengar oleh telinga manusia karena memiliki frekuensi tinggi, dapat merambat dalam medium padat, cair, dan gas(42).Karakteristik gelombang ultrasonik yang melewati medium mengakibatkan getaran partikel medium amplitudo sejajar dengan arah rambat secara longitudinal, sehingga menyebabkan partikel medium membentuk rapatan (strain) dan regangan (stress). Proses yang kontinu menyebabkan terjadinya rapatan dan renggangan di dalam medium yang disebabkan oleh getaran partikel secara periodik pada saat gelombang ultrasonik melewatinya. Kecepatan dan penyerapan ultrasonik akanberbeda dalam medium perambatanyang juga berbeda. Ini disebabkan karena interaksi gelombang ultrasonik yang terjadi bergantungpada ciriciri fisik medium perambatan dan mekanisme interaksi gelombangultrasonik dengan bahan. Kecepatan perambatan gelombang longitudinalbergantung pada modulus elastik yang setara dengan modulus pukal dan densitimedium.dipengaruhi oleh parameter sonication, seperti daya input, waktu sonicasi, diameter probe, dan frekuensi sonikasion(43). Gelombang ultrasonik apabila berada dalam medium cair dapat menyebabkan kavitasi akustik. Selama proses kavitasi berlangsung terjadi bubble collapse (ketidakstabilan gelembung), yaitu pecahnya gelembung yang kecil akibat suara. Akibatnya terjadi peristiwa hotspot melibatkan energi yang sangat tinggi. Hotspot adalah pemanasan lokal yang sangat intens yaitu sekitar $5000 \mathrm{~K}$ pada tekanan 1000 atm, laju pemanasan dan pendinginan bisa sangat cepat yaitu sekitar $10^{10} \mathrm{~K} / \mathrm{s}$.

Pemberian gelombang ultrasonik pada suatu larutanakan menyebabkan molekul-molekul dalam larutan berosilasi terhadap posisi rata-ratanya. Larutan mengalami regangandan rapatan. Ketika energi gelombang ultrasonik yang diberikan cukup besar, maka regangan gelombang dapat memecah ikatan molekul antar larutan(44), dan gas-gas yang terlarut didalam larutan akan terperangkap akibat molekul larutan yang ikatannya terpecah ketika timbul rapatan kembali. Akibatnya timbul bola-bola berongga atau gelembung-gelembung berisi gas yang terperangkap, yang dikenal dengan efek kavitasi. Gelembung-gelembung ini bisa memiliki diameter 
yang membesar sehingga ukurannya maksimum, kemudian berkontraksi dan mengecil sehingga volumenya berkurang, bahkan beberapa hingga seluruhnya menghilang.

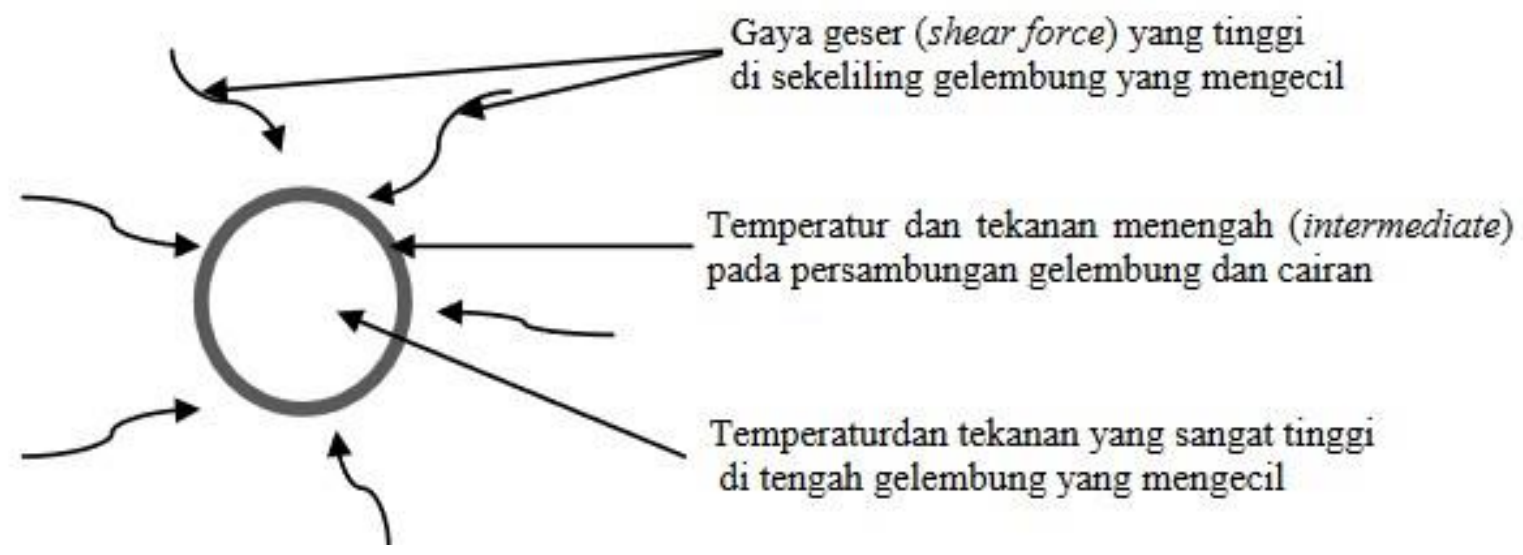

Gambar 1. Ilustrasi temperatur, tekanan, dan gaya geser yang timbul ketika gelembung mengecil (Collapse)(45)

Berbagai macam penelitian dengan memanfaatkan teknologi sonikasi dalam berbagai bidang telah dilakukan. Di bidang kesehatan : Pengaruh penuaan gumpalan dan kadar kolesterol pada trombolisis dengan menggunakan ultrasound(46), sonikasi katup jantung mendeteksi lebih banyak bakteri di endokarditis infektif(47). Bidang industri: Energi ultrasonik untuk mempercepat penyerapan pewarna dan interaksi pewarna-serat pewarna reaktif pada kain katun rajutan pada suhu rendah(48), bidang biologi: Optimalisasi ekstraksi ultrasonik(49) dan aktivitas antioksidan in vitro dari polisakarida dari Trametes orientalis(50). Di bidang kimia: Sintesis, proses pertumbuhan, karakterisasi alpha- $\mathrm{MnO}_{2(51)}$ nanourchin-terstruktur dan aplikasinya pada pencucian adsorptif dengan bantuan ultrasonik(52).Biosorpsi Pb (II)(53) dari larutan berair oleh lengkeng (Euphoria logan lour) benih dan cangkang(54) dengan metode sonikasi juga dapat dilakukan.Pada bidang industri, untuk menghasilkan molekul bioaktif bernilai tinggi, ekstraksi ultrasoundadalah alternatif yang menarik untuk untuk meningkatkan kemurnian dan hasil(55). Pada bidang kesehatan, 
perangkat ultrasound(56) implan telah dikembangkan untuk pembukaan tulang tengkorak(57).

\section{Metode}

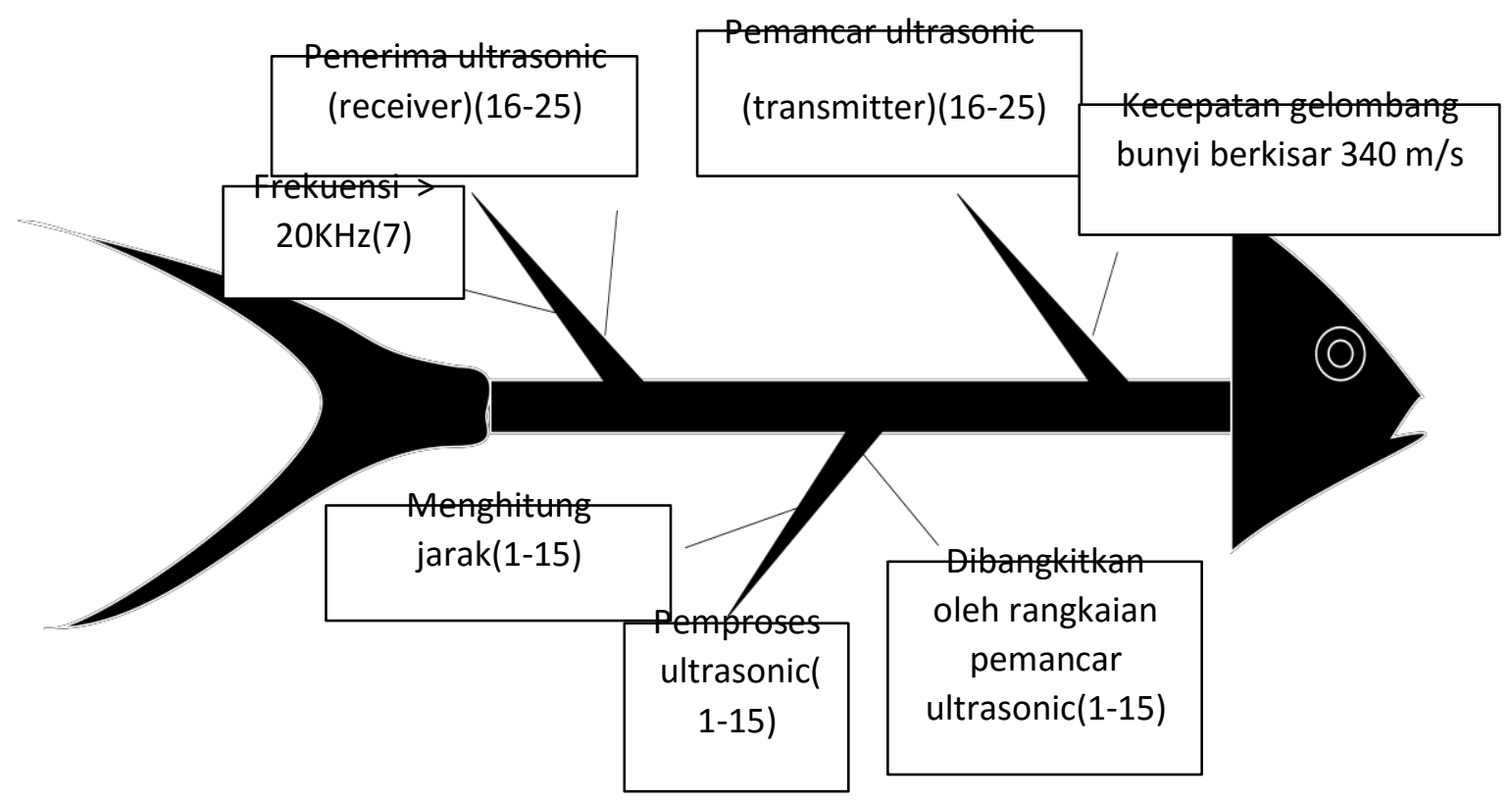

Gambar 1. Fish bone penggunaan metode sonikasi 
ultrasound

langsung (AS) ${ }^{[16]}$,

Depolimerisasi[17]

, Degradasi[18],

Bagan 1. Roadmap perkembangan penggunaan metode sonikasi

2000: Aplikasi ultrasound dengan pendingin air internal untuk terapi termal interstisial bertenaga tinggi(58)

2001: Depolimerisasi ultrasonik dari polivinil alkohol encer(59)

2002: Degradasi sonokimia polutan organik aromatik(60)

2007: Pemodelan transduser ultrasonik frekuensi tinggi menggunakan struktur periodik(61)

2012: Metode oksidasi ultrasonik dipercepat untuk menentukan stabilitas oksidatif biodiesel(62)

2017: Sintesis yang dibantu oleh ultrasound dari nanopartikel organik partikel Zinc (II) dengan adanya modulator untuk peningkatan adsorpsi 2,4-diklorofenol dan amoksisilin(63)

2018: Kombinasi budaya konvensional, budaya vial, dan PCR luas cairan sonikasi untuk diagnosis infeksi sendi prostetik(64) 


\section{Pembahasan}

Semenjak perkembangannya sinar ultrasoniktelah digunakan pada berbagai bidang(65; 66). Dalam bidang kesehatan, gelombang ultrasonik digunakan untuk melihat organ-organ dalam tubuh manusia seperti untuk mendeteksi tumor, liver, otak dan menghancurkan batu ginjal. Gelombang ultrasonik juga dimanfaatkan pada alat USG (ultrasonografi)(67) yang biasa digunakan oleh dokter kandungan(68).Pada bidang kesehatan ultrasound di gunakan untuk mendeteksi sejumlah penyakit yang sulit terdeteksi(69), diantaranya batu kantong empedu(70), batu saluran empedu(71), sistem urinasi (perkemihan)(72; 73), Sistem kardiovaskuler (jantung dan pembuluh darah)(74-76), usus buntu(77-79), pembesaran kelenjar getah bening, keganasan pada kantong empedu atau saluran empedu dan penyakit keganasan pankreas. Gelombang ultrasound jugaa bisa digunakan untuk mendeteksi penyakit diabetes mellitus $(\mathrm{DM})(80)$ yangdi derita seseorang. Dengan menggunakan sonokimia penelitian pada aktivasi tanah napa dan pengaruhnya terhadap adsorpsi ion timbal (II)/Pb2+(81) juga dapat dilakukan.

Dalam bidang industri, gelombang ultrasonik(71) digunakan untuk mendeteksi keretakan pada logam(82), mensterilkan makanan yang diawetkan dalam kaleng, meratakan campuran besi dan timah(83), meratakan campuran susu agar homogen(84), dan membersihkan benda benda yang sangat halus. Gelombang ultrasonik juga digunakan untuk mendeteksi keberadaan mineral dan minyak bumi yang tersimpan di dalam perut bumi(85).Dalam bidang pertahanan, gelombang ultrasonik digunakan sebagai radar atau navigasi, di darat maupun di dalam air. Gelombang ultrasonik digunakan oleh kapal pemburu untuk mengetahui keberadaan kapal selam, dipasang pada kapal selam untuk mengetahui keberadaan kapal yang berada di atas permukaan air, mengukur kedalaman palung laut, mendeteksi ranjau, dan menentukan posisi sekelompok ikan.

Pada tahun 2000, aplikasi ultrasound digunakan pada pendingin air internal untuk terapi termal interstisial bertenaga tinggi(86). Mekanisme pendinginan air diintegrasikan ke dalam lumen bagian dalam aplikator untuk mengeluarkan panas 
dari permukaan dari bagian dalam transduser. Tingginya perpindahan panas konvektif (2100-3800 W / m2K) diukur pada laju aliran air praktis 20-80 mL / menit. Pengukuran akustik komparatif menunjukkan pendinginan air internal tidak secara signifikan menurunkan intensitas akustik atau distribusi berkas transduser AS bagian dalam(87). Pendinginan air dilakukan pada daya listrik yang tinggi (> $45 \mathrm{~W}$. Uji pemanasan suhu tinggi dilakukan dengan aplikator in vivo (otot porcine dan paha) dan secara in vitro(88) (hati sapi) menunjukkan peningkatan penetrasi dan koagulasi termal. Kedalaman radial koagulasi dari permukaan aplikator berkisar antara 12 hingga $20 \mathrm{~mm}$ untuk 1-5 menit dengan daya yang diterapkan 28-W. Kekuatan yang lebih tinggi (41 W) menunjukkan peningkatan kedalaman koagulasi (sekitar $9 \mathrm{~mm}$ ) pada waktu yang lebih pendek (15 detik). Dimensi lesi termal (sudut dan bentangan aksial) yang dihasilkan dengan aplikator terarah dikontrol dan diarahkan, dan berhubungan dengan zona aktif transduser(86). Bentuk lesi khas ini umumnya tidak berubah dengan waktu dan kekuatan sonikasi yang berbeda. Implementasi air pendingin adalah kemajuan yang signifikan untuk penerapan terapi termal interstisial ultrasound (USITT)(89), menghasilkan volume pengobatan yang lebih besar, waktu perawatan yang lebih singkat, dan potensi untuk pengobatan jaringan dengan perfusi yang tinggi dengan lesi berbentuk(58).

Pada tahun 2001, Ultrasonikasi terbukti sebagai metode yang menguntungkan untuk depolimerisasi makromolekul(90) karena mengurangi berat molekul dengan memisahkan ikatan kimia yang paling rentan tanpa menyebabkan perubahan dalam sifat kimia polimer(91). Efek yang terlibat dalam mengendalikan berat molekul dapat dikaitkan dengan gradien geser besar dan gelombang kejut yang dihasilkan di sekitar runtuhnya gelembung kavitasi(66; 92). Secara umum, untuk setiap proses degradasi(93) polimer(94) supaya diterima oleh industri, perlu untuk menentukan kondisi sonicasi yang mengarah pada distribusi massa molar relatif (77)tertentu yang mengharuskan identifikasi daya iradiasi yang tepat(95; 96), suhu, konsentrasi dan waktu iradiasi(97). Hasil dari penilitian ini reaktor yang dibangun bekerja dengan baik dalam depolimerisasi(98) dan memungkinkan untuk 
mendegradasi(99) polimer polivinil alkohol encer (PVA) dengan ultrasound. Degradasi paling luas terjadi pada frekuensi terendah, yaitu $23 \mathrm{kHz}$, ketika daya input berada di atas ambang kavitasi dan pada konsentrasi uji PVA terendah, yaitu 1\% (b / b)(100). Dengan demikian gaya geser yang dihasilkan oleh gerakan cepat pelarut setelah runtuhnya cavitational bertanggung jawab atas kerusakan ikatan kimia di dalam polimer(101). Pengaruh konsentrasi polimer dapat ditafsirkan dalam peningkatan viskositas dengan konsentrasi, menyebabkan molekul menjadi kurang bergerak dalam larutan dan gradien kecepatan di sekitar gelembung runtuh sehingga menjadi lebih kecil(59; 102).

Pada tahun 2002, penggunaan ultrasound digunakan untuk membuat mineralisasi 4-klorofenol, 2,4-diklorofenol, [aril-2H3] 2,4-diklorofenol, 4-kloro-3,5dimetilfenol, 4-fluorofenol, 2,4,6- trinitrotoluena, 2-amino-4,6-dinitrotoluena dan 4amino-2,6-dinitrotoluena dalam larutan encer encer(103). Tingkat mineralisasi ditentukan sebagai fungsi struktur substrat dan konsentrasi(104), fasa curah(105), pH(104)dan keberadaan zat terlarut seperti deterjen dan asam humat(106). Semua substrat ditemukan menurun selama sonokimia(89), dibuktikan oleh Cl- dan NO3masing-masing(107). Analisis produk dengan GC-MS(108), HPLC, dan kromatografi kapiler elektrokinetik micellar (MECC) menunjukkan mineralisasi(109) dengan sedikit pembentukan produk sampingan organik(56), keuntungan yang signifikan dibandingkan metode remediasi lainnya. Pelepasan klorida dari klorofenol kira-kira proporsional dengan substrat total kandungan klorin(92), terlepas dari perbedaan struktural, dan mencapai $80 \%$ dari batas teoritis. Pelepasan fluorida dari 4fluorophenol adalah 10 kali lipat lebih rendah daripada klorida dari 4-klorofenol(101; 110). Perubahan suhu fasa curah dari 9,5 hingga 34 derajat $C$, dan 12,5 hingga 30 derajat $\mathrm{C}$, masing-masing, merupakan konsekuensi kecil terhadap tingkat mineralisasi yang diamati untuk nitroaromatics dan chlorophenols(111). Peningkatan tingkat mineralisasi yang signifikan dihasilkan dari sonication 4-chlorophenol dalam media yang diasamkan. Penambahan amphiphilic co-solutes menghasilkan peningkatan sonolysis yang sederhana, tetapi signifikan secara statistik(60). 
Pada tahun 2007 sebuah transduser terintegrasi dipasang secara padat pada sel Bragg dan disisipkan di antara film piezoelektrik dan substrat diselidiki dengan aplikasi ultrasonik frekuensi tinggi(26). Sebuah model transmisi / refleksi satu dimensi (112)rekursif numerik stabil digunakan untuk menganalisis perilaku struktur periodik. Analisis teoritis merupkan studi tentang pengaruh sifat akustik dari lapisan konstitutif(113), pengaruh jumlah sel dan pengaturannya. Transduser terintegrasi 35 $\mathrm{MHz}(66)$ yang terdiri dari keramik PZT dan diletakkan pada sel Au / PZT Bragg yang disimpan pada substrat berpori-pori dan dikarakterisasi(114; 115). Hasil menunjukkan minat meningkat dengan penggunaan struktur periodik untuk aplikasi ultrasonik frekuensi tinggi(61).

Pada tahun 2012, telah dikembangkan metode alternatif yang cepat dan sederhana untuk menentukan waktu induksi (IT) berdasarkan oksidasi dipercepat ultrasonik FAAS(115). Sonodegradation sampel biodiesel diinduksi menggunakan homogenizer ultrasonik(116) yang dilengkapi tanduk immersible pada daya 480 Watt dan 20 siklus(117). Spektrometri UV-Vis digunakan untuk memantau sonodegradasi FAAS dengan mengukur absorbansi pada $270 \mathrm{~nm}$. Sampel biodiesel diperoleh dari bahan baku yang berbeda. TI dijadikan sebagai titik infleksi dari absorbansi terhadap kurva waktu. Nilai waktu induksi dari semua sampel biodiesel ditentukan menggunakan metode yang diusulkan adalah sesuai dengan yang diukur melalui metode referensi Rancimat $(\mathrm{R})$ dengan menunjukkan $\mathrm{R}(2)=0,998(62)$.

Pada tahun 2017, digunakan metode sonochemical pada kerangka Zn (TDC) (4-BPMH)] dan (H2O) yang dihasilkan oleh Zn (TDC) (4-BPMH)] dalam bentuk tiga dimensi dan berpori yang disebut senyawa 1(35). Pengikat yang digunakan adalah dikarboksilat dari TDC, (2,5-tiofena asam dikarboksilat) dan spacer pilar 4-BPMH, (N, N-bis-pyridin-4-ylmethylene-hydrazine(114). Selain itu, variasi dalam morfologi dan pertumbuhan mikro / nanopartikel(118) senyawa 1 diselidiki dalam hal efek suhu, kekuatan iradiasi ultrasound(119), waktu sonication(83), konsentrasi reagen awal, dan konsentrasi piridin sebagai modulator(67). Model DFT dapat digunakan untuk memeriksa efek sonikasi pada distribusi ukuran pori. Selain itu, metode 
preparasi berpengaruh terhadap porositas dan penghilangan dua polutan sampel (yaitu, 2,4-diklorofenol (24-DCP) dan amoksisilin (AMX)) dari air limbah(63).

Pada tahun 2018, dilakukan penelitian penilaian konvensional, vial, dan PCR luas dari cairan sonikasi (SF)(120), dilakukan diagnosis infeksi sendi prostetik (PJI) secara individu dan kelompok(121). Dari 114 pasien berturut-turut (usia ratarata: 72,5 tahun, laki-laki: $28,07 \%$ ) mengalami pengangkatan total prostesis lutut atau panggul. Dengan kriteria non-mikrobiologis $(91 ; 122)$, 87 pasien mengalami kegagalan aseptik, dan 27 PJI(74). Semua pasien memiliki kultur jaringan periprostetik(123), sonikasi prostesis(124), dan studi SF dengan budaya konvensional dan vial, dan PCR(125). Dibandingkan dengan kultur jaringan, setiap tes secara signifikan lebih sensitif dan kurang spesifik. Jika hanya satu tes positif, sensitivitasnya adalah $88,46 \%$ dan spesifisitas $64,29 \%$. Jika ketiga tes SF positif, sensitivitas, dan NPV menurun (34,6\% dan 80,23\%), tetapi spesifisitas dan PPV meningkat hingga 98,57\% dan 90,9\%, masing-masing, mengalahkan kultur jaringan. Tes triple negative praktis tidak termasuk PJI(64).

\section{Kesimpulan}

Sonikasi merupakan teknologi menggunakan energi suara untuk menggerakkan partikel yang bearada dalam suatu sampel untuk berbagai keperluan. Sonikasi berarti pemberian perlakuan ultrasonik suatu bahan pada kondisi tertentu, sehingga menyebabkan bahan tersebut mengalami reaksi kimia sebagai akibat perlakuan teyang diberikan. Prosesnya dengan menggunakan gelombang ultrasonik pada rentang frekuensi $20 \mathrm{KHz}-10 \mathrm{MHz}$ atau yang dikenal dengan istilah ultrasonikasi. Seiring perkembangannya teknologi sonikasi telah digunakan dalam berbagai bidang, seperti industri, kesehatan, kimia, dan biologi. 
1. Awad EM, El Masady I, Rammah YS, Abu-Shady M. 2018. Simulating the radial dose distribution for charged particles in water medium by a semi-empirical model: An analytical approach. Appl Radiat Isot 142:135-42

2. Bennett JJR, Sherratt JA. 2018. Long-distance seed dispersal affects the resilience of banded vegetation patterns in semi-deserts. J Theor Biol

3. Codner JA, Lou X, Duwayri YM, Chen EP, Binongo JN, et al. 2018. The distance of the primary intimal tear from the left subclavian artery predicts aortic growth in uncomplicated type B aortic dissection. J Vasc Surg

4. Crowther LJ, Brunner P, Kapeller C, Guger C, Kamada K, et al. 2018. A quantitative method for evaluating cortical responses to electrical stimulation. Journal of neuroscience methods

5. Fakhoury E, Provencher JA, Subramaniam R, Finlay DJ. 2018. Not all lightweight lead aprons and thyroid shields are alike. $J$ Vasc Surg

6. Fujisaki H, Moritsugu K, Mitsutake A, Suetani H. 2018. Conformational change of a biomolecule studied by the weighted ensemble method: Use of the diffusion map method to extract reaction coordinates. The Journal of chemical physics 149:134112

7. Hoffmann R, Valgeirsdottir VV, Johannesson OI, Unnthorsson R, Kristjansson A. 2018. Measuring relative vibrotactile spatial acuity: effects of tactor type, anchor points and tactile anisotropy. Exp Brain Res

8. Kang CM, Kim W, Chung CC. 2018. Observer-based backstepping control method using reduced lateral dynamics for autonomous lane-keeping system. ISA Trans

9. La Rovere MT, Pinna GD, Pin M, Bruschi C, Callegari G, et al. 2018. Exercise Training After Pulmonary Endarterectomy for Patients with Chronic Thromboembolic Pulmonary Hypertension. Respiration:1-8

10. Neugebauer M, Tautz L, Hullebrand M, Sundermann S, Degener F, et al. 2018. Virtual downsizing for decision support in mitral valve repair. Int I Comput Assist Radiol Surg

11. Peukert S, Kijak M, Ostapko J, Sepiol J, Le Bris C, et al. 2018. Supersonic jet spectroscopy of parent hemiporphycene: Structural assignment and vibrational analysis for S0 and S1 electronic states. The Journal of chemical physics 149:134307

12. Singleton JM, Garland T, Jr. 2018. Influence of corticosterone on growth, home-cage activity, wheel running, and aerobic capacity in house mice selectively bred for high voluntary wheel-running behavior. Physiol Behav

13. Xun Y, Li J, Geng Y, Liu Z, Yu X, et al. 2018. Single extracorporeal shock-wave lithotripsy for proximal ureter stones: Can CT texture analysis technique help predict the therapeutic effect? European journal of radiology 107:84-9

14. Yang TC, South SJ. 2018. Neighborhood effects on body mass: Temporal and spatial dimensions. Soc Sci Med 217:45-54

15. Zimmermann F, Liebensteiner MC, Balcarek P. 2018. The reversed dynamic patellar apprehension test mimics anatomical complexity in lateral patellar instability. Knee Surg Sports Traumatol Arthrosc 
16. Jafarzadeh E, Sinclair AN. 2018. Non-linear Wave Propagation and Safety Standards for Diagnostic Ultrasound Devices. Ultrasound in medicine \& biology

17. Xie JX, You JH, Chen XK, Su YM, Liu JR, et al. 2018. Three-dimensional sonographic minute structure analysis of fetal cerebellar vermis development and malformations: utilizing volume contrast imaging. J Med Ultrason (2001)

18. Ducousso M, Dalodiere A, Baillard A. 2018. Evaluation of the thermal aging of aeronautical composite materials using Lamb waves. Ultrasonics

19. Huang H, Ling W, Qiu T, Luo Y. 2018. Ultrasonographic features of testicular metastasis from renal clear cell carcinoma that mimics a seminoma: A case report. Medicine (Baltimore) 97:e12728

20. Eghbali A, Seyssens L, De Bruyckere T, Younes F, Cleymaet R, Cosyn J. 2018. A 5-year prospective study on the clinical and aesthetic outcome of alveolar ridge preservation and connective tissue graft at the buccal aspect of single implants. Journal of clinical periodontology

21. Xu J, Gu Z, Yang W, Wang Q, Zhang X. 2018. Graphene-Based Nanoscale Vacuum Channel Transistor. Nanoscale research letters 13:311

22. Coelho MS, Lacerda M, Silva MHC, Rios MA. 2018. Locating the second mesiobuccal canal in maxillary molars: challenges and solutions. Clin Cosmet Investig Dent 10:195-202

23. Gallo M, Ferrara L, Naviglio D. 2018. Application of Ultrasound in Food Science and Technology: A Perspective. Foods 7

24. Marques AC, Aguiar BA, Frota LM, Guimaraes BM, Vivacqua-Gomes N, et al. 2018. Evaluation of Influence of Widening Apical Preparation of Root Canals on Efficiency of Ethylenediaminetetraacetic Acid Agitation Protocols: Study by Scanning Electron Microscopy. J Contemp Dent Pract 19:1087-94

25. Topper VY, Reilly MP, Wagner LM, Thompson LM, Gillette R, et al. 2018. Social and neuromolecular phenotypes are programmed by prenatal exposures to endocrinedisrupting chemicals. Mol Cell Endocrinol

26. Arain MS, Kazi TG, Afridi HI, Ali J, Akhtar A. 2017. Ultrasonic energy enhanced the efficiency of advance extraction methodology for enrichment of trace level of copper in serum samples of patients having neurological disorders. Ultrasonics sonochemistry 37:23-8

27. Garcia-Vaquero M, Rajauria G, O'Doherty JV, Sweeney T. 2017. Polysaccharides from macroalgae: Recent advances, innovative technologies and challenges in extraction and purification. Food research international 99:1011-20

28. Akgedik R, Aytekin I, Kurt AB, Eren Dagli C. 2016. Recurrent pneumonia due to olive aspiration in a healthy adult: a case report. The clinical respiratory journal 10:809-10

29. Roobab U AR, Madni GM, Bekhit AED. 2018. The impact of nonthermal techmologies on the microbiological quality of juices: A review. Comprehensive Reviews in Food Science and Food Safety:1-21

30. Suslick KS. 1990. Sonochemistry. Science 247:1439

31. Peshkovsky AS, Peshkovsky SL, Bystryak S. 2013. Scalable high-power ultrasonic technology for the production of translucent nanoemulsions. Chem. Eng. Process. 69:77-82 
32. Maatta J, Kautiainen H, Leinonen V, Niinimaki J, Jarvenpaa S, et al. 2014. Association of Modic changes with health-related quality of life among patients referred to spine surgery. Scandinavian journal of pain 5:36-40

33. Golmohamadi A, Möller G, Powers J, Nindo C. 2013. Effect of ultrasound frequency on antioxidant activity, total phenolic and anthocyanin content of red raspberry puree. Ultrasonics sonochemistry 20:1316-23

34. Al Emam A, Sricharoen N. 2016. Left Main Coronary Spasm: an Extremely Rare Entity with Possible Life-Threatening Complications. The International journal of angiology : official publication of the International College of Angiology, Inc 25:e149-e52

35. Amaral DC, Lopes G, Guilherme LR, Seyfferth AL. 2017. A New Approach to Sampling Intact Fe Plaque Reveals Si-Induced Changes in Fe Mineral Composition and Shoot As in Rice. Environmental science \& technology 51:38-45

36. Kalender M, Tasar M, Karaca OG, Ecevit AN, Darcin OT. 2016. Carotid patch and cerebrovascular event relation after carotid endarterectomy procedure. The Journal of cardiovascular surgery 57:888-92

37. Zainul R. 2018. Determination of the half-life and the quantum yield of ZnO semiconductor photocatalyst in humic acid.

38. Rahadian Zainul BO, Indang Dewata. 2018. Studi Dinamika Molekular dan Kinetika Reaksi pada Pembelahan Molekul Air untuk Produksi Gas Hidrogen.

39. Rahadian Zainul AA, Hermansyah Aziz, Syukri Arief, Syukri, Edison Munaf. 2015. Design of Photovoltaic Cell with Copper Oxide Electrode by using Indoor Lights. Research Journal of Pharmaceutical Biological and Chemical Science 6:353-61

40. Rahadian Zainul DN, Marniati Salim. 2018. Optimization of Spirulina Platensis Culture for Antioxidant Production.

41. Suslick KS, Price GJ. 1999. APPLICATIONS OF ULTRASOUNDTO MATERIALS CHEMISTRY. Annu. Rev. Mater. Sci 29:295-326

42. Zhou B FH, Luo Y. 2009. Ultrasound enhanced sanitizer efficacy in reduction of Escherichia coli 0157:H7 population on spinach leaves. Journal of Food Science 74:308-13

43. Cai X, Jiang Z, Zhang X, Zhang X. 2018. Effects of Tip Sonication Parameters on Liquid Phase Exfoliation of Graphite into Graphene Nanoplatelets. Nanoscale research letters 13:241

44. Arif Yasthopi Rahadian Zainul AA, Hermansyah Aziz, Syukri Arief, Syukri. 2015. Photoelectrosplitting Water for Hydrogen Production Using Illumination with Indoor Lights. Journal of Chemical and Pharmaceutical Research 7:57-67

45. Mason T, Lorimer JP. 2002. Applied Sonochemistry: The Uses of Power Ultrasound in Chemistry and Processing.

46. Zhou Y, Murugappan SK, Sharma VK. 2014. Effect of clot aging and cholesterol content on ultrasound-assisted thrombolysis. Translational stroke research 5:627-34

47. Gomes A, van Oosten M, Bijker KLB, Boiten KE, Salomon EN, et al. 2018. Sonication of heart valves detects more bacteria in infective endocarditis. Scientific reports 8:12967 
48. Tissera ND, Wijesena RN, de Silva KM. 2016. Ultrasound energy to accelerate dye uptake and dye-fiber interaction of reactive dye on knitted cotton fabric at low temperatures. Ultrasonics sonochemistry 29:270-8

49. Hanafi A, Kamali M, Darvishi MH, Amani A. 2018. Pretreatment with Ultrasonication Reduces the Size of Azelaic Acid-Chitosan Nanoparticles Prepared by Electrospray.

Archives of Razi Institute 73:53-9

50. Zheng Y, Li Y, Wang WD. 2014. Optimization of ultrasonic-assisted extraction and in vitro antioxidant activities of polysaccharides from Trametes orientalis. Carbohydrate polymers 111:315-23

51. Rahadian Zainul AA, Hermansyah Aziz, Syukri Arief, Syukri Darajat. 2015. Modifikasi dan Karakteristik I-V Sel Fotovoltaik Cu2O/Cu-Gel Na2SO4 Melalui Illuminasi Lampu Neon. EKSAKTA Berkala Ilmiah Bidang MIPA 2:50

52. Abraham R, Mathew S, Kurian S, Saravanakumar MP, Mary Ealias A, George G. 2018. Facile synthesis, growth process, characterisation of a nanourchin-structured alpha$\mathrm{MnO} 2$ and their application on ultrasonic-assisted adsorptive removal of cationic dyes: A half-life and half-capacity concentration approach. Ultrasonics sonochemistry 49:175-89

53. Mawardi Anwar EM, Soleh Kosela, Widayanti Wibowo, Rahadian Zainul. 2015. Study of $\mathrm{Pb}$ (II) Biosorption from Aqueous Solution Using Immobilized Spirogyra Subsalsa Biomass. Journal of Chemical and Pharmaceutical Research 7:715-22

54. Desy Kurniawati IL, Salmariza Sy Harmiwati, Zulkarnain Chaidir, Edison Munaf, Rahmiana Zein, Hermansyah Aziz, Rahadian Zainul. 2015. Biosorption of Pb (II) from Aqueous Solutions Using Column Method by Lengkeng (Euphoria logan lour) Seed and Shell. Journal of Chemical and Pharmaceutical Research 7:872-7

55. Bamba BSB, Shi J, Tranchant CC, Xue SJ, Forney CF, Lim LT. 2018. Influence of Extraction Conditions on Ultrasound-Assisted Recovery of Bioactive Phenolics from Blueberry Pomace and Their Antioxidant Activity. Molecules 23

56. Zhou B FH, Luo Y. 2009. Ultrasound enhanced sanitizer efficacy in reduction of Escherichia coli 0157:H7 population on spinach leaves. Journal of food science 74:308-13

57. Beccaria K, Canney M, Goldwirt L, Fernandez C, Piquet J, et al. 2016. Ultrasoundinduced opening of the blood-brain barrier to enhance temozolomide and irinotecan delivery: an experimental study in rabbits. Journal of neurosurgery 124:1602-10

58. Deardorff DL, Diederich CJ. 2000. Ultrasound applicators with internal water-cooling for high-powered interstitial thermal therapy. IEEE transactions on bio-medical engineering 47:1356-65

59. Gronroos A, Pirkonen P, Heikkinen J, Ihalainen J, Mursunen H, Sekki H. 2001. Ultrasonic depolymerization of aqueous polyvinyl alcohol. Ultrasonics sonochemistry 8:259-64

60. Goskonda S, Catallo WJ, Junk T. 2002. Sonochemical degradation of aromatic organic pollutants. Waste management 22:351-6 
61. Marechal P, Haumesser L, Tran-Huu-Hue LP, Holc J, Kuscer D, et al. 2008. Modeling of a high frequency ultrasonic transducer using periodic structures. Ultrasonics 48:141-9

62. Avila Orozco FD, Sousa AC, Domini CE, Ugulino Araujo MC, Fernandez Band BS. 2013. An ultrasonic-accelerated oxidation method for determining the oxidative stability of biodiesel. Ultrasonics sonochemistry 20:820-5

63. Abazari R, Mahjoub AR. 2018. Ultrasound-assisted synthesis of Zinc(II)-based metal organic framework nanoparticles in the presence of modulator for adsorption enhancement of 2,4-dichlorophenol and amoxicillin. Ultrason Sonochem 42:577-84

64. Stylianakis A, Schinas G, Thomaidis PC, Papaparaskevas J, Ziogas DC, et al. 2018. Combination of conventional culture, vial culture, and broad-range PCR of sonication fluid for the diagnosis of prosthetic joint infection. Diagnostic microbiology and infectious disease 92:13-8

65. Abel E, De Wall SL, Edwards WB, Lalitha S, Covey DF, Gokel GW. 2000. Formation of stable vesicles from $\mathrm{N}$ - or 3-alkylindoles: possible evidence for tryptophan as a membrane anchor in proteins. The Journal of organic chemistry 65:5901-9

66. Abram F, Gunnigle E, O'Flaherty V. 2009. Optimisation of protein extraction and 2DE for metaproteomics of microbial communities from anaerobic wastewater treatment biofilms. Electrophoresis 30:4149-51

67. Wang J, Ding L, Li K, Schmieder W, Geng J, et al. 2017. Development of an extraction method and LC-MS analysis for N-acylated-I-homoserine lactones (AHLs) in wastewater treatment biofilms. Journal of chromatography. B, Analytical technologies in the biomedical and life sciences 1041-1042:37-44

68. Zimmer S, Fosca M, Roulet JF. 2000. Clinical study of the effectiveness of two sonic toothbrushes. The Journal of clinical dentistry 11:24-7

69. Zisu B, Bhaskaracharya R, Kentish S, Ashokkumar M. 2010. Ultrasonic processing of dairy systems in large scale reactors. Ultrasonics sonochemistry 17:1075-81

70. Upadhyay P, Trivedi J, Pundarikakshudu K, Sheth N. 2017. Direct and enhanced delivery of nanoliposomes of anti schizophrenic agent to the brain through nasal route. Saudi pharmaceutical journal : SPJ : the official publication of the Saudi Pharmaceutical Society 25:346-58

71. Baghbani F, Chegeni M, Moztarzadeh F, Hadian-Ghazvini S, Raz M. 2017. Novel ultrasound-responsive chitosan/perfluorohexane nanodroplets for image-guided smart delivery of an anticancer agent: Curcumin. Materials science \& engineering. $C$, Materials for biological applications 74:186-93

72. Ho E, Omari A. 2017. Prevalence of Acute Deep Vein Thrombosis in Patients with Ankle and Foot Fractures Treated with Nonoperative Management-A Pilot Study. The International journal of angiology : official publication of the International College of Angiology, Inc 26:53-9

73. Huang PC, Pande P, Ahmad A, Marjanovic M, Spillman DR, Jr., et al. 2016. Magnetomotive Optical Coherence Elastography for Magnetic Hyperthermia Dosimetry Based on Dynamic Tissue Biomechanics. IEEE journal of selected topics in quantum electronics : a publication of the IEEE Lasers and Electro-optics Society 22 
74. Voegeli AV, Marcellini L, Sodano L, Perice RV. 2017. Clinical and radiological outcomes after distal oblique osteotomy for the treatment of stage II hallux rigidus: Mid-term results. Foot and ankle surgery : official journal of the European Society of Foot and Ankle Surgeons 23:21-6

75. Villa L, Giusti G, Knoll T, Traxer O. 2016. Imaging for Urinary Stones: Update in 2015. European urology focus 2:122-9

76. Vila-Rico J, Mellado-Romero MA, Bravo-Gimenez B, Jimenez-Diaz V, Ojeda-Thies C. 2017. Subtalar arthroscopic arthrodesis: Technique and outcomes. Foot and ankle surgery : official journal of the European Society of Foot and Ankle Surgeons 23:9-15

77. Takechi K, Konishi A, Kikuchi K, Fujioka S, Fujii T, et al. 2015. Real-time ultrasoundguided infraorbital nerve block to treat trigeminal neuralgia using a high concentration of tetracaine dissolved in bupivacaine. Scandinavian journal of pain $6: 51-4$

78. Strydom A, Saragas NP, Ferrao PN. 2017. A radiographic analysis of the contribution of hallux valgus interphalangeus to the total valgus deformity of the hallux. Foot and ankle surgery : official journal of the European Society of Foot and Ankle Surgeons 23:27-31

79. Smith M, Medlock G, Johnstone AJ. 2017. Percutaneous screw fixation of unstable ankle fractures in patients with poor soft tissues and significant co-morbidities. Foot and ankle surgery : official journal of the European Society of Foot and Ankle Surgeons 23:16-20

80. VK Sharma CC, Rahadian Zainul, PS Naruka, HP Singh, CS Sharma. Journal of Chemical and Pharmaceutical Research (ISSN: 0975-7384).

81. Suci Rahma Yani RZ. 2018. Aktivasi Tanah Napa dan Pengaruhnya Terhadap Adsorpsi Ion Timbal (II)/Pb2+.

82. Ambrosi A, Sofer Z, Luxa J, Pumera M. 2016. Exfoliation of Layered Topological Insulators Bi2Se3 and Bi2Te3 via Electrochemistry. ACS nano 10:11442-8

83. Askari H, Ghaedi M, Dashtian K, Azghandi MHA. 2017. Rapid and high-capacity ultrasonic assisted adsorption of ternary toxic anionic dyes onto MOF-5-activated carbon: Artificial neural networks, partial least squares, desirability function and isotherm and kinetic study. Ultrasonics sonochemistry 37:71-82

84. Zhang X, Zhang Y, Guo S, Bai F, Wu T, Zhao Y. 2016. Improved oral bioavailability of 20(R)-25-methoxyl-dammarane-3beta, 12beta, 20-triol using nanoemulsion based on phospholipid complex: design, characterization, and in vivo pharmacokinetics in rats. Drug design, development and therapy 10:3707-16

85. Zainul R. 2018. Design and Modification of Copper Oxide Electrodes for Improving Conversion Coefficient Indoors Lights (PV-Cell) Photocells.

86. Adekunte A, Tiwari BK, Scannell A, Cullen PJ, O'Donnell C. 2010. Modelling of yeast inactivation in sonicated tomato juice. International journal of food microbiology 137:116-20

87. Sharma N, Srivastava S, Kern F, Xian W, Ming T, et al. 2016. Endoscopic modalities for the diagnosis of Barrett's oesophagus. United European gastroenterology journal 4:733-40 
88. Wareing N, Szymanski K, Akkaraju GR, Loni A, Canham LT, et al. 2017. In Vitro Gene Delivery with Large Porous Silicon Nanoparticles Fabricated Using Cost-Effective, Metal-Assisted Chemical Etching. Small 13

89. Xiao K, Chen Y, Jiang X, Zhou Y. 2017. Evaluating filterability of different types of sludge by statistical analysis: The role of key organic compounds in extracellular polymeric substances. Chemosphere 170:233-41

90. Babu AS, Mohan RJ, Parimalavalli R. 2019. Effect of single and dual-modifications on stability and structural characteristics of foxtail millet starch. Food chemistry 271:457-65

91. Zitron R, Wajsfeld T, Klautau GB, da Silva CB, Nigro S, et al. 2016. Concentration of Sonication Fluid through Centrifugation Is Superior to Membrane Filtration for Microbial Diagnosis of Orthopedic Implant-Associated Infection. Journal of clinical microbiology 54:788-90

92. Silva DDS, Dos Santos CS, Pando LA, Gomes MSR, Novaes CG, et al. 2019. Doehlert design in the optimization of ultrasound assisted dissolution of fish fillet samples with tetramethyl ammonium hydroxide for metals determination using FAAS. Food chemistry 273:71-6

93. Rahadian Zainul ID. 2018. Determination of $\mathrm{pH}-\mathrm{BOD}-\mathrm{COD}$ and degradation in batang arau watersheds at Padang city.

94. Ahmad R, Nicora CD, Shukla AK, Smith RD, Qian WJ, Liu AY. 2016. An efficient method for native protein purification in the selected range from prostate cancer tissue digests. Chinese clinical oncology 5:78

95. Sauter A, Breivik H. 2015. Ultrasound-guided high concentration tetracaine peripheral nerve block: Effective and safe relief while awaiting more permanent intervention for tic douloureux. Scandinavian journal of pain 6:50

96. Sabatino R, Aquino G, Pinto A, Piris MA, Marra L, et al. 2017. B-cell lymphoblastic lymphoma presenting as solitary temporal mass with amplification of AML1/RUNX1: case report. Hematological oncology 35:380-4

97. Khan MR, Khan JM, Alqadami AA. 2019. A simple solvent extraction and ultraperformance liquid chromatography-tandem mass spectrometric method for the identification and quantification of rhodamine B in commercial lip balm samples. Spectrochimica acta. Part A, Molecular and biomolecular spectroscopy 206:72-7

98. Liao AH, Ma WC, Wang CH, Yeh MK. 2016. Penetration depth, concentration and efficiency of transdermal alpha-arbutin delivery after ultrasound treatment with albumin-shelled microbubbles in mice. Drug delivery 23:2173-82

99. Adam A, Farnsworth R. 2016. Catastrophic haemorrhage from ureterocele incision in an infant: beware of an associated iliac arteriovenous malformation. ANZ journal of surgery 86:942-4

100. Alam I, Sharmin S, Kim KH, Kim YG, Lee J, Lee BH. 2013. An improved plant leaf protein extraction method for high resolution two-dimensional polyacrylamide gel electrophoresis and comparative proteomics. Biotechnic \& histochemistry : official publication of the Biological Stain Commission 88:61-75 
101. Amiri A, Memarpoor-Yazdi M, Shanbedi M, Eshghi H. 2013. Influence of different amino acid groups on the free radical scavenging capability of multi walled carbon nanotubes. Journal of biomedical materials research. Part A 101:2219-28

102. Zhu Z, Wei H, Wu G, Yang H, He Y, Xie S. 2012. Synergistic effect of hyperosmotic agents and sonophoresis on breast tissue optical properties and permeability studied with spectral domain optical coherence tomography. Journal of biomedical optics 17:086002

103. Al-Zaydi KM, Borik RM, Mekheimer RA, Elnagdi MH. 2010. Green chemistry: a facile synthesis of polyfunctionally substituted thieno[3,4-c]pyridinones and thieno[3,4d]pyridazinones under neat reaction conditions. Ultrasonics sonochemistry 17:90915

104. Lee HN, Lee YS, Han DH, Lee KS. 2017. Change of Ultrasound Estimated Bladder Weight and Bladder Wall Thickness After Treatment of Bladder Outlet Obstruction With Dutasteride. Lower urinary tract symptoms 9:67-74

105. Philippou Y, Parker RA, Volanis D, Gnanapragasam VJ. 2016. Comparative Oncologic and Toxicity Outcomes of Salvage Radical Prostatectomy Versus Nonsurgical Therapies for Radiorecurrent Prostate Cancer: A Meta-Regression Analysis. European urology focus 2:158-71

106. Xiao W, Zhou W, Feng T, Zhang Y, Liu H, Tian L. 2016. Simple Synthesis of Molybdenum Disulfide/Reduced Graphene Oxide Composite Hollow Microspheres as Supercapacitor Electrode Material. Materials 9

107. Backes C, Hanlon D, Szydlowska BM, Harvey A, Smith RJ, et al. 2016. Preparation of Liquid-exfoliated Transition Metal Dichalcogenide Nanosheets with Controlled Size and Thickness: A State of the Art Protocol. Journal of visualized experiments : JoVE

108. Wu SK, Chiang CF, Hsu YH, Liou HC, Fu WM, Lin WL. 2017. Pulsed-wave low-dose ultrasound hyperthermia selectively enhances nanodrug delivery and improves antitumor efficacy for brain metastasis of breast cancer. Ultrasonics sonochemistry 36:198-205

109. Zhu S, Guo J, Dong J, Cui Z, Lu T, et al. 2013. Sonochemical fabrication of Fe304 nanoparticles on reduced graphene oxide for biosensors. Ultrasonics sonochemistry 20:872-80

110. Zhou C, Vitiello V, Casals E, Puntes VF, lamunno F, et al. 2016. Toxicity of nickel in the marine calanoid copepod Acartia tonsa: Nickel chloride versus nanoparticles. Aquatic toxicology 170:1-12

111. Arun C, Sivashanmugam P. 2017. Study on optimization of process parameters for enhancing the multi-hydrolytic enzyme activity in garbage enzyme produced from preconsumer organic waste. Bioresource technology 226:200-10

112. Xu G, Hao C, Tian S, Gao F, Sun W, Sun R. 2017. A method for the preparation of curcumin by ultrasonic-assisted ammonium sulfate/ethanol aqueous two phase extraction. Journal of chromatography. B, Analytical technologies in the biomedical and life sciences 1041-1042:167-74

113. Yuksel F, Karatas D, Turkdogan FT, Yuksel O. 2018. Increased Atherosclerosis Correlates with Subjective Tinnitus Severity. Indian journal of otolaryngology and 
head and neck surgery : official publication of the Association of Otolaryngologists of India 70:119-24

114. Afrasiabi R, Kraatz HB. 2013. Sonication-induced coiled fibrous architectures of BocL-Phe-L-Lys(Z)-OMe. Chemistry 19:1769-77

115. Zhou X, Zhao J, Li Z, Song J, Li X, et al. 2016. Enhancement effects of ultrasound on secondary wastewater effluent disinfection by sodium hypochlorite and disinfection by-products analysis. Ultrasonics sonochemistry 29:60-6

116. Zhang N, Zhao H, Zhang G, Chong S, Liu Y, et al. 2017. Preparation of a magnetic N$\mathrm{Fe} / \mathrm{AC}$ catalyst for aqueous pharmaceutical treatment in heterogeneous sonication system. Journal of environmental management 187:201-11

117. Zuliani T, Lespes G, Milacic R, Scancar J. 2010. Development of the extraction method for the simultaneous determination of butyl-, phenyl- and octyltin compounds in sewage sludge. Talanta 80:1945-51

118. Zhao WP, Chen JY, Zhang L, Li Q, Qin J, et al. 2013. Feasibility of ultrasound-guided high intensity focused ultrasound ablating uterine fibroids with hyperintense on T2weighted MR imaging. European journal of radiology 82:e43-9

119. Zhou XJ, Guo WQ, Yang SS, Zheng HS, Ren NQ. 2013. Ultrasonic-assisted ozone oxidation process of triphenylmethane dye degradation: evidence for the promotion effects of ultrasonic on malachite green decolorization and degradation mechanism. Bioresource technology 128:827-30

120. Aspenberg P. 2017. Comment to a BMJ Editorial. Acta orthopaedica 88:1

121. Anjomshoa M, Torkzadeh-Mahani M, Dashtrazmi E, Adeli-Sardou M. 2016. Sonochemical Synthesis and Characterization of the Copper(II) Nanocomplex: DNAand BSA-Binding, Cell Imaging, and Cytotoxicity Against the Human Carcinoma Cell Lines. Journal of fluorescence 26:545-58

122. Abfalter CM, Schmidt TP, Wessler S. 2015. Proteolytic Activities Expressed by Gastrointestinal Pathogens Bacillus cereus, Listeria monocytogenes and Enterococcus faecium in Different Growth Phases. British microbiology research journal 7:62-70

123. Amaral A, Castillo J, Estanyol JM, Ballesca JL, Ramalho-Santos J, Oliva R. 2013. Human sperm tail proteome suggests new endogenous metabolic pathways. Molecular \& cellular proteomics : MCP 12:330-42

124. Boyce AM, Florenzano P, de Castro LF, Collins MT. 1993. Fibrous Dysplasia/McCuneAlbright Syndrome. In GeneReviews((R)), ed. MP Adam, HH Ardinger, RA Pagon, SE Wallace, LH Bean, et al. Seattle (WA). Number of.

125. Annegowda HV, Bhat R, Min-Tze L, Karim AA, Mansor SM. 2012. Influence of sonication treatments and extraction solvents on the phenolics and antioxidants in star fruits. Journal of food science and technology 49:510-4 
a review

\title{
CHEMICAL VAPOR DEPOSITION : PROCESS AND APLICATION
}

\author{
Agil Aditya Dinata $^{*}$, Abel Maaruf Rosyadi ${ }^{2}$, Syukri Hamid $^{2}$, Rahadian Zainul ${ }^{2}$ \\ ${ }^{1}$ Pendidikan Kimia,FMIPA, Universitas Negeri Padang, Indonesia \\ ${ }^{2}$ Pendidikan Kimia,FMIPA, Universitas Negeri Padang, Indonesia \\ ${ }^{3}$ Pendidikan Kimia,FMIPA, Universitas Negeri Padang, Indonesia \\ ${ }^{4}$ Physical Chemistry Laboratory, Universitas Negeri Padang, Indonesia \\ *E-mail :agiladityadinata@gmail.com, maarufrosyadi@gmail.com \\ Syukrihamid58@yahoo.co.id, rahadianzmsiphd@yahoo.com
}

\begin{abstract}
Abstrak. Chemical Vapor Deposition merupakan metode deposisi yang digunakan untuk menghasilkan bahan padat berkualitas tinggi dan berkinerja tinggi yang biasanya dibawah vakum. Tujuan review ini adalah untuk mengetahui proses dan teknik dari Chemical Vapor Deposition. Prinsip kerja dari Chemical Vapor Deposition yaitu proses pengendapan senyawa/ unsur terjadi akibat reaksi dekomposisi kimia akibat aktivasi termal di seputar komponean yang dilapisi. Beberapa material yang dihasilkan dengan menggunakan metode Chemical Vapor Deposition ini adalah berlian sintesis, thin film coating, lapisan emas dengan ketebalan yang tipis.
\end{abstract}

Keywords: vapor deposition, prinsip, proses.

\section{Pendahuluan}

Dalam pembuatan material terdapat beberapa metode yang dapat digunakan, salah satunya adalah dengan metode Chemical Vapor Deposition. Metode Chemical Vapor Deposition banyak digunakan dalam pembuatan thin film coating dan baru-baru ini menghasilkan berlian sintetis. Chemical Vapor Deposition merupakan proses pengendapan senyawa atau unsur terjadi akibat reaksi dekomposisi kimia akibat adanya aktivasi termal di seputar komponen yang dilapisi(53-57). Pada proses Chemical Vapor Deposition, substrat diletakkan di depan pada satu atau lebih prekursor yang bereaksi pada permukaan substrat untuk menghasilkan deposit yang diinginkan, kemudian dikeluarkan oleh aliran gas melalui reaksi ruangan. Chemical Vapor Deposition telah lama berkembang, seperti literature yang telah kami dapatakan yaitu dari tahun 2000-2018, sudah banyak sekali yang dihasilkan oleh Chemical Vapor Deposition.(61-67)

\section{Metode}

Pada proses Chemical Vapor Deposition dapat menghasilkan kualitas den kinerja yang tinggi dibandingkan dengan metode lain. Proses Chemical Vapor Deposition berlangsung dalam beberapa tahapan yang dapat dilihat pada fishbone di bawah ini. 


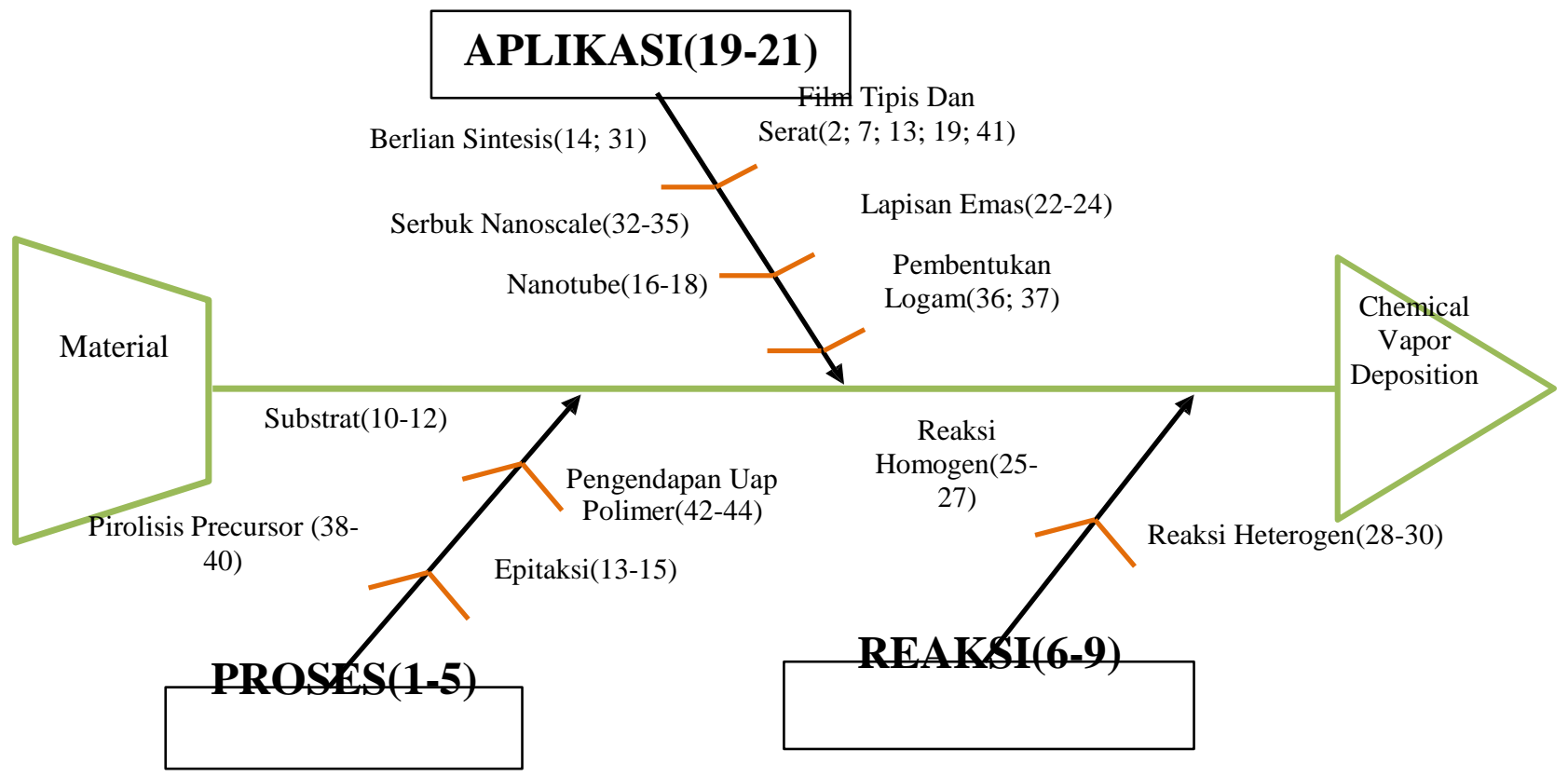

Bagan 1. FishBone Chemical Vapor Deposition

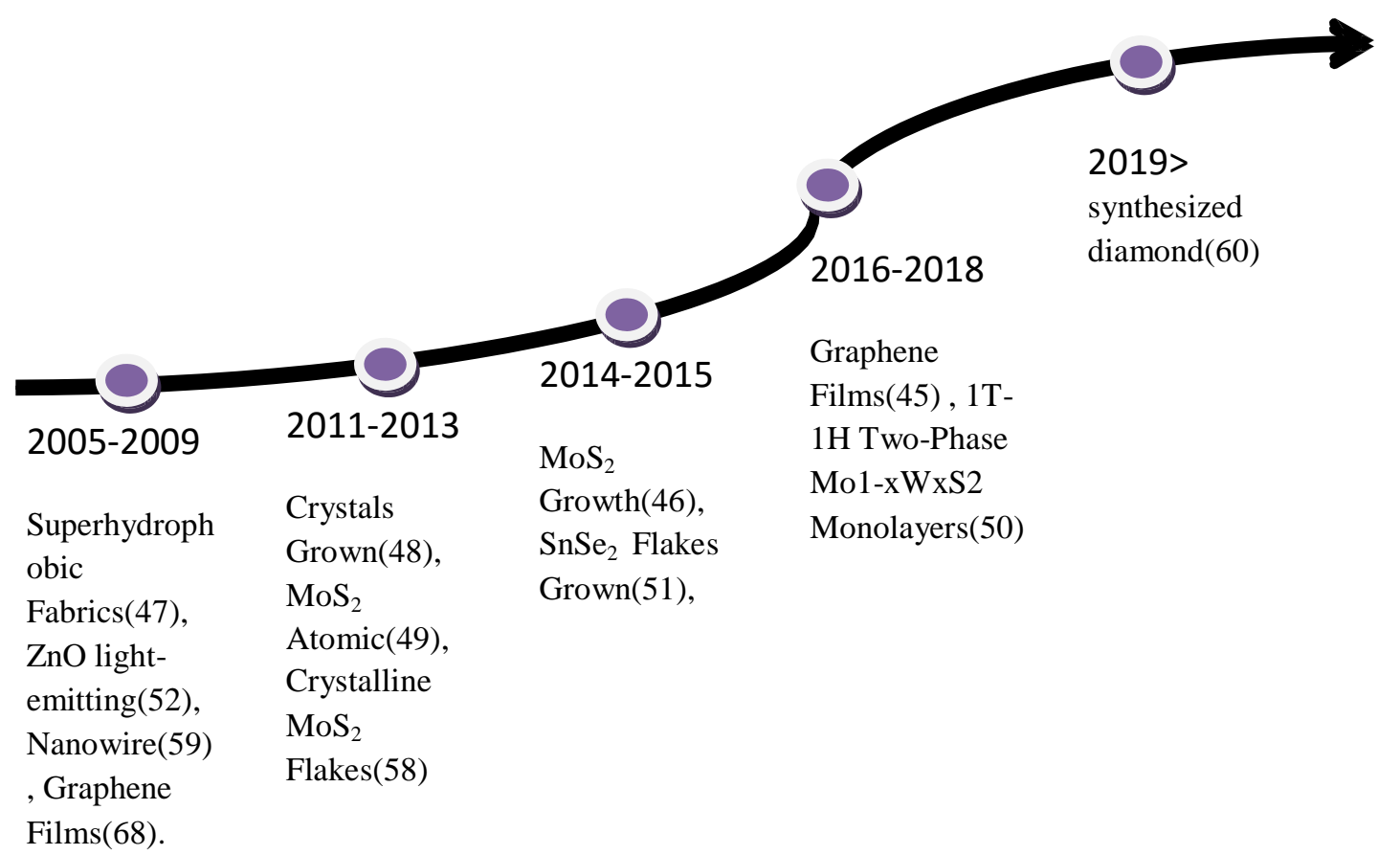

Bagan 2. Road maps Chemical Vapor Deposition 
Keterangan :

2005 Superhydrophobic Fabrics Produced by Electrospinning and Chemical Vapor Deposition

$2006 \mathrm{ZnO}$ light-emitting diode grown by plasma-assisted metal organic chemical vapor deposition

2007 Rational Synthesis of p-Type Zinc Oxide Nanowire Arrays Using Simple Chemical Vapor Deposition

2008 Large Area, Few-Layer Graphene Films on Arbitrary Substrates by Chemical Vapor Deposition

2009 Synthesis, Transfer, and Devices of Single- and Few-Layer Graphene by Chemical Vapor Deposition

2011 Large-Area Graphene Single Crystals Grown by Low-Pressure Chemical Vapor Deposition of Methane on Copper

2012 Synthesis of Large Area $\mathrm{MoS}_{2}$ Atomic Layers with Chemical Vapor Deposition

2013 Controlled Synthesis of Highly Crystalline $\mathrm{MoS}_{2}$ Flakes by Chemical Vapor Deposition

2014 Role of the Seeding Promoter in $\mathrm{MoS}_{2}$ Growth by Chemical Vapor Deposition

2015 Ultrathin $\mathrm{SnSe}_{2}$ Flakes Grown by Chemical Vapor Deposition for High- Performance Photodetector

2016 Synthesis of Graphene Films on Copper Foils by Chemical Vapor Deposition

2018 Synthesizing 1T-1H Two-Phase Mo1-xWxS2 Monolayers by Chemical Vapor Deposition

\section{Hasil dan Pembahasan}

Deposisi uap kimia (CVD) adalah teknologi pengolahan material yang banyak digunakan. Kebanyakan aplikasinya melibatkan penerapan lapisan tipis-film padat ke permukaan, tetapi juga digunakan untuk memproduksi bahan curah dengan kemurnian tinggi dan bubuk, serta fabrikasi komposit melalui teknik infiltrasi(19-21).

Saat ini, CVD adalah alat dasar manufaktur yang digunakan dalam segala hal mulai dari kacamata hitam hingga tas keripik kentang dan sangat penting untuk memproduksi beberapa perangkat elektronik saat ini. CVD merupakan teknik pada pemurnian dan ekspansi konstan, mendorong penelitian material ke arah baru, seperti produksi lembaran skala besar graphene, atau pengembangan sel surya yang bisa "dicetak" ke selembar kertas atau plastik(13; 14; 31; 69).

Pada tahun 2005, CVD memproduksi kain superhidrofobik(47). Suatu metode serbaguna yang menghasilkan kain superhydrophobic dengan menggabungkan electrospinning dan diprakarsai oleh deposisi uap kimia (CVD). Poli (caprolactone) (PCL) adalah electrospun pertama dan kemudian dilapisi dengan lapisan tipis hidrofobik terpolimerisasi perfluoroalkyl ethyl methacrylate (PPFEMA) oleh iCVD. Permukaan hierarkis kekasaran yang melekat pada tikar PCL electrospun dan energi bebas permukaan yang sangat rendah lapisan pelapis yang diperoleh oleh iCVD menghasilkan superhidrofobisitas yang stabil.

Pada tahun 2006, ZnO light-emitting diode(52) yang dikembangkan oleh deposisi uap kimia organik dengan bantuan logam plasma. Sebuah terobosan dalam pembuatan $\mathrm{ZnO}$ light-emitting diode oleh metal deposisi uap kimia organik. Dengan menggunakan plasma NO, apat menumbuhkan tipe-P $\mathrm{ZnO}$ tipis film pada substrat $\mathrm{ZnO}$ n-jenis massal

Pada tahun 2007, CVD digunakan dalam mensintesis Rasional P-Type Zinc Oxide Nanowire Arrays(59). untuk pertama kalinya, sintesis dari P-type ZnO NWs berkualitas tinggi menggunakan metode deposisi uap kimia sederhana, di mana fosfor pentoksida telah digunakan sebagai sumber dopan.

Pada tahun 2008, CVD digunakan pada lapisan film graphene(70) yang sedikit dengan substrat yang berubah-rubah. Dalam pekerjaannya yang menyajikan teknik biaya rendah dan terukur, melalui 
tekanan ambien deposisi uap kimia (CVD) pada film Ni polikristalin, untuk membuat film yang luas ( $\mathrm{cm} 2$ ) dari graphene satu ke beberapa lapisan dan untuk mentransfer film ke substrat nonspesifik.

Pada tahun 2009, CVD digunakan dalam sintesis, transfer, dan perangkat Single- and FewLayer Graphene(68). Kemajuan nanoelectronics berbasis graphene telah terhambat karena kesulitan dalam menghasilkan graphene satu atau beberapa layer di area yang luas. Dengan menggunakan CVD , dapat hemat biaya untuk menyiapkan graphene menggunakan CVD berbasis metana pada film nikel disimpan di atas wafer $\mathrm{Si} / \mathrm{SiO} 2$ yang lengkap.

Pada tahun 2011, Large-Area Graphene Single Crystals Grown by Low-Pressure(48) yang dikembangkan oleh CVD dari metana dan copper. Kristal tunggal graphene dengan dimensi hingga 0,5 mm pada sisi dikembangkan oleh deposisi uap kimia pada tempat tembaga-foil menggunakan metana sebagai prekursor.Analisis mikroskop elektron berenergi rendah menunjukkan bahwa domain graphene besar memiliki orientasi kristalografi tunggal, dengan domain sesekali memiliki dua orientasi.

Pada tahun 2012, CVD digunakan dalam mensintesis Large Area $\mathrm{MoS}_{2}$ lapisan atom(49). Large Area $\mathrm{MoS}_{2}$ lapisan atom disintesis pada substrat $\mathrm{SiO}_{2}$ oleh deposisi uap kimia menggunakan bubuk $\mathrm{MoO}_{3}$ dan $\mathrm{S}$ sebagai reaktan. Pengukuran optik, mikroskopik dan listrik menunjukkan bahwa proses sintetis mengarah pada pertumbuhan monolayer $\mathrm{MoS}_{2}$. Gambar TEM memverifikasi bahwa lembaran $\mathrm{MoS}_{2}$ yang disintesis sangat kristalin.

Pada tahun 2013, CVD digunakan dalam mensintesis Highly Crystalline $\mathrm{MoS}_{2}$ Flakes(58). Sintesis yang dikendalikan dari lapisan atom $\mathrm{MoS}_{2}$ yang sangat kristalin tetap menjadi tantangan. mensintesis serpihan $\mathrm{MoS}_{2}$ dalam bentuk rhomboid dengan jumlah lapisan yang dikontrol oleh lapisan sulfurisasi mikrokristal $\mathrm{MoO}_{2}$. Serpihan $\mathrm{MoS}_{2}$ yang diperoleh menunjukkan tinggi kristalinitas dengan ukuran domain kristal $\sim 10 \mu \mathrm{m}$, secara signifikan lebih besar dari ukuran butir $\mathrm{MoS}_{2}$ tumbuh dengan metode lain.

Pada tahun 2014, CVD digunakan dalam promotor penyemaian dalam Pertumbuhan $\mathrm{MoS}_{2}(46)$. Memanfaatkan berbagai molekul aromatik sebagai penyemaian promotor, monolayer $\mathrm{MoS}_{2}$ yang besar, sangat kristalin, dan seragam dicapai dengan deposisi uap kimia (CVD) pada suhu pertumbuhan yang relatif rendah $\left(650^{\circ} \mathrm{C}\right)$.

Pada tahun 2015, CVD mengembangkan ultrathin $\mathrm{SnSe}_{2}$ Flakes(51) untuk photodetector berperforma tinggi. Ultrathin tunggal berkualitas tinggi $\mathrm{SnSe}_{2}$ serpihan kristal tunggal disintesis di bawah atmosfer-tekanan deposisi uap kimia untuk pertama kalinya. Fotodetektor berkinerja tinggi berdasarkan serpihan $\mathrm{SnSe}_{2}$ menunjukkan photoresponsivity tinggi 1,1 × 103AW- 1, EQE tinggi 2,61 $\times 105 \%$, dan detektif luar biasa dari 1,01 × 1010 Jones, digabungkan dengan waktu yang naik dan peluruhan cepat masing-masing 14,5 dan $8,1 \mathrm{~ms}$.

Pada tahun 2016, CVD digunakan dalam mensintesis Graphene Films on Copper Foils(45). graphene telah berkembang pesat sebagai salah satu baham yang paling menjanjikan bagi kehidupan manusia. Pengembangan metodologi sintetis produksi yang layak untuk persiapan berbagai jenis graphene membentuk dasar untuk penyelidikan dan aplikasi. Graphene dapat digunakan dalam bentuk bubuk mikroflake atau area besarfilm tipis. Serbuk graphene disiapkan oleh pengelupasan grafit atau reduksi graphene oxide, sementara film graphene dipersiapkan terutama oleh uap kimia.

Pada tahun 2018, CVD digunakan dalam mensintesis 1T-1H Two-Phase Mo1-xWxS Monolayers(50). 1T - 1H antarmuka logam-semikonduktor dalam dua-dimensi (2D) transisi-logam Dichalcogenides (TMDs) memainkan peran penting dalam memanfaatkan celah pita TMDs untuk aplikasi di perangkat elektronik. Meskipun struktur dua fase $1 \mathrm{~T}-1 \mathrm{H}$ telah diamati pada nanosheet 2D yang terkelupas dan TMD yang diolah secara kimia atau fisik, tidak bisa pada prinsipnya dicapai dalam monolayers TMD berskala besar yang ditanam oleh deposisi uap kimia (CVD), yang merupakan metode fabrikasi untuk aplikasi perangkat elektronik, karena sifat metastabil dari fase 1T. Pertumbuhan CVD dari 1T-1H dua fase monolayers TMD dengan mengendalikan strain dan komposisi paduan termal. Ditemukan bahwa strain termal di dalam pesawat yang timbul dari perbedaan dalam koefisien ekspansi termal antara monolayer TMD dan substrat dapat mendorong transisi $1 \mathrm{H}$ ke $1 \mathrm{~T}$ selama 
pendinginan setelah pertumbuhan CVD. Selain itu, batas butir dalam kristal 2D bertindak sebagai situs nukleasi fase 1T dan gangguan regangan kisi dari paduan jelas meningkatkan pembentukan fase 1T metastabil. Pekerjaan ini memiliki implikasi penting dalam menyesuaikan struktur dan sifat CVD yang dikembangkan 2D TMD oleh rekayasa fase.

Seiring berkembangnya teknologi metode CVD dapat digunakan dalam pembuatan berlian sintesis $(60 ; 71 ; 72)$.

Deposisi uap kimia (CVD) mengacu pada pembentukan film padat non-volatil pada substrat dari reaksi reaktan kimia fase uap yang mengandung konstituen yang tepat. Ruang reaksi digunakan untuk proses ini, di mana gas-gas reaktan diperkenalkan untuk menguraikan dan bereaksi dengan substrat untuk membentuk film(73-75).

Pertumbuhan CVD terjadi ketika gas atau uap (prekursor) dimasukkan ke dalam reaktor suhu rendah di mana wafer disusun baik secara vertikal maupun horizontal. Gas bergerak melalui sistem dan mendistribusikan secara merata di seluruh permukaan wafer. Saat prekursor ini bergerak melalui reaktor, wafer mulai menyerapnya ke permukaannya(76; 77).

Setelah prekursor didistribusikan secara merata di seluruh sistem, reaksi kimia dimulai di sepanjang permukaan substrat. Reaksi kimia ini dimulai sebagai pulau, dan seiring proses berlanjut, pulau-pulau tumbuh dan bergabung untuk menciptakan film yang diinginkan. Reaksi kimia menciptakan biproduk pada permukaan wafer, yang berdifusi melintasi lapisan batas dan mengalir keluar dari reaktor, meninggalkan hanya wafer dengan lapisan film yang disimpan $(13 ; 14 ; 31 ; 69)$.

Dalam inkarnasi yang paling sederhana, CVD melibatkan aliran gas atau gas prekursor ke dalam bilik yang mengandung satu atau lebih benda yang dipanaskan untuk dilapisi. Reaksi kimia terjadi pada permukaan panas, menghasilkan pengendapan lapisan film tipis di permukaan. Ini disertai dengan produksi produk sampingan kimia yang kehabisan ruang bersama gas prekursor yang tidak bereaksi(64; 78-80). Seperti yang diharapkan dengan berbagai macam material yang disimpan dan berbagai macam aplikasi, ada banyak jenis CVD. Itu dilakukan di reaktor hot-wall dan reaktor dinding dingin, pada tekanan total sub-torr tekanan di atas atmosfer, dengan dan tanpa gas pembawa, dan pada suhu biasanya berkisar antara $200-1600^{\circ} \mathrm{C}$. Ada juga berbagai proses CVD yang ditingkatkan, yang melibatkan penggunaan plasma, ion, foton, laser, filamen panas, atau reaksi pembakaran meningkatkan tingkat deposisi / deposisi pada suhu yang lebih rendah. Ada banyak turunan terminologi CVD, seperti deposisi uap kimia logam-organik (MOCVD), deposisi uap kimia organo-metalik (OMCVD), yang kadang digunakan untuk mencatat kelas molekul yang digunakan dalam proses deposisi. Beberapa praktisi memilih membedakan deposisi film epitaxial dari deposisi film polikristalin atau amorf, jadi mereka memperkenalkan berbagai istilah yang termasuk "Epitaxy" dalam akronim. Dua lagi jenis umum adalah fase uap organologam epitaxy (OMVPE) 7 dan fase uap metalorganik epitaksi (MOVPE) yang sering digunakan dalam epitaksi semikonduktor senyawa $(4 ; 5 ; 41 ; 81 ; 82)$.

CVD memiliki sejumlah keunggulan sebagai metode untuk menyimpan film tipis. Salah satu keunggulan utama adalah film-film CVD umumnya cukup konformal, yaitu filmnya memiliki ketebalan di dinding samping fitur sebanding dengan ketebalan di bagian atas. Ini berarti film dapat diterapkan secara terperinci yaitu potongan berbentuk, termasuk bagian dalam dan bagian bawah fitur, dan rasio aspek-tinggi lubang dan fitur lainnya dapat terisi penuh. Sebaliknya, teknik deposisi uap fisik (PVD), seperti sputtering atau penguapan, umumnya membutuhkan garis-of-sight antara permukaan yang akan dilapisi dan sumbernya. Keuntungan CVD lainnya yaitu selain luas berbagai material yang bisa disimpan, mereka dapat disimpan dengan kemurnian sangat tinggi. Ini hasil dari kemudahan relatif yang kotoran dibuang dari prekursor gas menggunakan teknik distilasi. Keunggulan lainnya termasuk tingkat deposisi yang relatif tinggi, dan fakta bahwa CVD sering kali tidak membutuhkan setinggi vakum sebagai proses PVD(83-85).

Salah satu keuntungan besar dari pengolahan CVD adalah dapat menciptakan lapisan dengan ketebalan yang seragam bahkan dalam bentuk yang kompleks. Misalnya, CVD dapat digunakan untuk menyatukan tabung karbon nanotube silinder kecil dari karbon murni yang jauh lebih ramping daripada 
rambut seperti untuk memodifikasi sifat mekanik mereka dan membuat mereka bereaksi secara kimia terhadap zat tertentu(86-89).

CVD juga memiliki sejumlah kerugian. Salah satu kelemahan utama terletak pada sifat-sifat prekursor. Idealnya itu prekursor harus mudah berubah di dekat ruangan suhu. Ini bukan angka sepele elemen dalam tabel periodik, meskipun penggunaan prekursor logam-organik telah mereda. Prekursor CVD juga bisa sangat beracun (Ni (CO)), eksplosif, atau korosif $\left(\mathrm{SiCl}_{2}\right)$. Produk sampingan dari reaksi CVD bisa juga berbahaya (CO,atau HF). Beberapa prekursor ini, terutama prekursor logam-organik, juga bisa sangat mahal. Kerugian utama lainnya adalah kenyataan bahwa film-film tersebut biasanya disimpan pada suhu tinggi. Ini memberi batasan pada jenis media yang bisa dilapisi. Lebih penting lagi, mengarah kepada menekankan pada film yang disimpan pada bahan dengan koefisien ekspansi termal yang berbeda, yang dapat menyebabkan ketidakstabilan mekanik di film yang disimpan.

\section{A. Proses Chemical Vapor Deposisi}

\section{a. Pengendapan uap polimer dan substrat}

Pengendapan uap polimer telah membuka pintu ke berbagai bahan yang akan sulit, dan dalam beberapa kasus dan tidak mungkin, untuk diproduksi dengan cara lain. Sebagai contoh, banyak polimer yang bermanfaat, seperti bahan penumpahan air untuk melindungi komponen industri atau implan biologis, dibuat dari prekursor yang tidak dapat larut, sehingga tidak dapat diproduksi menggunakan metode berbasis solusi konvensional(90-93). Pekerjaan Gleason pada CVD berbasis polimer dimulai pada 1990-an, ketika dia melakukan eksperimen dengan Teflon, senyawa klorin dan fluor. Pekerjaan itu mengarah ke bidang yang sekarang berkembang rinci dalam buku baru yang diedit Gleason, berjudul "CVD Polymers: Fabrikasi Permukaan dan Perangkat Organik"(74; 75; 94).

Pada saat itu, pemikiran satu-satunya adalah cara untuk membuat CVD bekerja dengan bahan polimer adalah dengan menggunakan plasma, sebuah gas bermuatan listrik untuk memulai reaksi. Gleason mencoba melakukan percobaan untuk membuktikan ini, dimulai dengan menjalankan eksperimen kontrol tanpa plasma untuk menunjukkan betapa pentingnya membuat proses bekerja. Sebaliknya, eksperimen yang kontrolnya bekerja dengan baik tanpa plasma sama sekali, membuktikan bahwa untuk banyak polimer langkah ini tidak diperlukan(32; 71; 95-97).

Tetapi peralatan yang digunakan Gleason memungkinkan temperatur gas dikontrol secara terpisah dari suhu substrat; memiliki pendingin substrat ternyata menjadi kunci. Dia melanjutkan untuk menunjukkan proses bebas plasma dengan lebih dari 70 polimer yang berbeda, membuka bidang penelitian baru(98-101). Proses ini membutuhkan banyak penyetelan, tetapi pada dasarnya merupakan serangkaian langkah sederhana: bahan yang akan dilapisi ditempatkan di dalam ruang vakum yang menentukan ukuran maksimum objek yang dapat dilapisi.Kemudian, bahan pelapis dipanaskan, atau tekanan di sekitarnya dikurangi sampai bahan menguap, baik di dalam ruang vakum atau di daerah yang berdekatan dari mana uap dapat diperkenalkan(102-106). Di sana, bahan yang ditangguhkan mulai mengendap ke bahan substrat dan membentuk lapisan yang seragam. Menyesuaikan suhu dan durasi proses memungkinkan untuk mengontrol ketebalan lapisan.

Dengan logam atau senyawa logam, seperti yang digunakan dalam industri semikonduktor, atau lapisan keperakan di dalam kantong makanan ringan, endapan logam uap yang dipanaskan pada substrat yang lebih dingin. Dalam proses polimer, itu sedikit lebih kompleks: Dua atau lebih senyawa prekursor yang berbeda, yang disebut monomer, dimasukkan ke dalam bilik, di mana mereka bereaksi untuk membentuk polimer ketika mereka mendepositkan pada permukaan $(1 ; 36 ; 107 ; 108)$.

Proses CVD dasar terdiri dari langkah - langkah berikut(63; 64; 109-111):

1) campuran gas reaktan yang telah ditentukan dan gas inert penguapan diperkenalkan pada laju alir yang ditentukan ke dalam ruang reaksi;

2) spesies gas pindah ke substrat; 
3) reaktan teradsorpsi pada permukaan substrat;

4) reaktan mengalami reaksi kimia dengan substrat untuk membentuk film; dan

5) produk samping gas dari reaksi yang diserap dan dievakuasi dari ruang reaksi.

Sistem CVD khas terdiri dari bagian-bagian berikut(78; 97; 112; 113):

1) sumber dan jalur umpan untuk gas;

2) pengendali aliran massa untuk mengukur gas ke dalam sistem;

3) ruang reaksi atau reaktor;

4) sistem untuk memanaskan wafer di mana film akan disimpan; dan

5) sensor suhu.

Ada banyak cara untuk menggambarkan atau mengklasifikasikan reaktor CVD. Misalnya, reaktor dikatakan 'hot-wall' jika menggunakan sistem pemanas yang memanaskan tidak hanya wafer, tetapi juga dinding reaktor itu sendiri, contohnya adalah pemanasan berseri-seri dari koil yang dipanaskan dengan resistansi. Reaktor 'Cold-wall' menggunakan sistem pemanas yang meminimalkan memanasnya dinding reaktor sementara wafer sedang memanas, contohnya adalah pemanasan melalui lampu IR di dalam reaktor. Dalam reaktor dinding-panas, film disimpan di dinding dengan cara yang sama seperti yang disimpan pada wafer, sehingga jenis reaktor ini memerlukan pembersihan dinding yang sering(114-116). Cara lain untuk mengklasifikasikan reaktor CVD adalah dengan mendasarkannya pada kisaran tekanan operasinya.Tekanan atmosfer CVD (APCVD) reaktor beroperasi pada tekanan atmosfer, dan oleh karena itu yang paling sederhana dalam desain.Tekanan rendah CVD (LPCVD) reaktor beroperasi pada vakum sedang (30-250 Pa) dan suhu yang lebih tinggi dari reaktor APCVD. Reaktor Plasma Enhanced CVD (PECVD) juga beroperasi di bawah tekanan rendah, tetapi tidak sepenuhnya bergantung pada energi panas untuk mempercepat proses reaksi.Mereka juga mentransfer energi ke gas reaktan dengan menggunakan pancaran cahaya yang diinduksi oleh RF(117-119).

Debit pijar yang digunakan oleh reaktor PECVD dibuat dengan menerapkan medan RF ke gas bertekanan rendah, menciptakan elektron bebas di dalam daerah pembuangan. Elektron cukup diberi energi oleh medan listrik bahwa disosiasi fase gas dan ionisasi gas-gas reaktan terjadi ketika elektron bebas bertabrakan dengan mereka. Spesies energetik kemudian diserap di permukaan film, di mana mereka terkena ion dan pembombardiran elektron, penataan ulang, reaksi dengan spesies lain, pembentukan ikatan baru, dan pembentukan dan pertumbuhan film(120-126).

\section{b. Pirolisis Prekursor}

Graphene CVD dibuat dalam dua langkah, pirolisis prekursor dari bahan untuk membentuk karbon, dan pembentukan struktur karbon graphene menggunakan atom karbon dipisahkan. Tahap pertama, pirolisis ke atom karbon yang dipisahkan, harus dilakukan pada permukaan substrat untuk mencegah pengendapan gugusan karbon (jelaga) selama fase gas. Masalah dengan ini adalah bahwa dekomposisi prekursor pirolitik membutuhkan tingkat panas yang ekstrim, dan oleh karena itu katalis logam harus digunakan untuk mengurangi suhu reaksi(18; 127-130).

Tahap kedua menciptakan struktur karbon dari atom karbon yang dipisahkan, juga membutuhkan tingkat panas yang sangat tinggi (lebih dari 2500 derajat Celcius tanpa katalis), jadi katalis sangat penting pada tahap ini untuk mengurangi suhu yang diperlukan untuk reaksi terhadap terjadi pada sekitar 1000 derajat Celcius. Masalah dengan menggunakan katalis adalah bahwa Anda secara efektif memasukkan lebih banyak senyawa ke dalam ruang reaksi, yang akan memiliki efek pada reaksi di dalam ruangan.Salah satu contoh dari efek ini adalah cara atom karbon larut ke dalam substrat tertentu seperti Nikel selama fase pendinginan(131-133).

Apa artinya semua ini adalah bahwa sangat penting bahwa proses CVD sangat ketat terkoordinasi, dan bahwa kontrol ditempatkan pada setiap tahap proses untuk memastikan bahwa reaksi 
terjadi secara efektif, dan bahwa kualitas graphene yang dihasilkan adalah dari yang tertinggi yang bisa dicapai(134-137).

\section{B. Aplikasi Chemical Vapor Deposisi}

Salah satu contoh awal dari Aplikasi CVD dengan skala besar adalah proses karbonil untukpemurnian nikel, seperti yang dikembangkan oleh Mond, Langer, dan Quincke pada tahun 1890. Banyak contoh aplikasi yaitu melibatkan pemurnian atau pemurnian logam dan sejumlah terbatas bukan logam dengan proses karbonil atau halida(89; 138-140). Aplikasi lainnya melibatkan deposisi pelapis untuk ketahanan aus dan korosi, dan pembuatan bentuk struktural dan komponen. Sebagian besar pekerjaan paling awal, hingga pertengahan 1960-an, ditinjau dalam buku oleh Powell, Oxley, dan Blocher. Banyak volume tinggi aplikasi, seperti pemurnian dan produksi bubuk dan pigmen, jelas masih penting secara ekonomi, tetapi sebagian besar baru-baru ini CVD R \& D upaya ini ditujukan untuk film tipis endapan. Ada banyak sekali R \& D yang sedang berlangsung mengenai CVD film tipis yang digunakan terutama untuk sifat mekanik atau kimia(86; 141; 142).

CVD telah menjadi teknologi pengaktifan yang penting di Indonesia mikroelektronika berbasis silikon; bahkan digunakan pada tahap awal selama pemurnian dan pemurnian silikon unsur.Bergantung kepada perangkat, proses CVD digunakan untuk menyetor film tipis semikonduktor aktif bahan (misalnya didoping $\mathrm{Si}$ ), konduktif interkoneksi (misalnya tungsten), atau isolasi dielektrik (misalnya $\mathrm{SiO}$ ).Revolusi komunikasi juga bergantung pada beragam teknologi CVD.Beberapa komponen mirip dengan yang digunakan dalam silikon mikroelektronika, tetapi banyak yang unik, melibatkan heterostruktur kompleks epitaxial SiGe atau Senyawa semikonduktor (misalnya, AlGaAs) paduan yang diperlukan untuk menghasilkan frekuensi tinggi (1-100 GHz) pengoperasian perangkat.Komunikasi revolusi juga bergantung pada optoelektronik komponen, seperti laser dioda solid state (perangkat heterostruktur kompleks lain), dan perangkat ini sering ditanam oleh CVD. Bahkan kabel serat optik yang mengirim optik komponen dari jaringan komunikasi diproduksi menggunakan teknik CVD untuk dicapai profil indeks bias yang diinginkan. Bahan optoelektronik yang ditanam oleh CVD yaitu pada industri komunikasi. Salah satu contohnya adalah untuk penerangan solid state menggunakan dioda pemancar cahaya (LED)(32; 33; 143-145). Baru-baru ini, Nichia Chemical adalah perusahaan pertama untuk mengkomersialkan kecerahan biru tinggi dan LED hijau berdasarkan nitrida kelompok-III paduan, misalnya InGaN, yang ditanam di atas substrat menggunakan teknologi CVD.Perusahaan ini juga memperkenalkan warna biru pertama dioda laser, berdasarkan bahan yang sama dan teknologi yang sama. Selain segudang pencahayaan dan aplikasi signage menggunakan LED berwarna, ada minat yang tumbuh dalam menghasilkan yang solid nyatakan sumber cahaya putih untuk menggantikan pijar dan mungkin bahkan sumber fluoresensi. Sumber cahaya putih dapat dicapai dari menggabungkan LED dari panjang gelombang yang berbeda, atau dengan memompa fosfor dengan LED ultraviolet $(131 ; 146-149)$.

Teknologi menarik lainnya memanfaatkan CVD adalah produksi mikroelektromekanik struktur, atau MEMS. Banyak dari MEMS teknologi berasal dari silikon teknologi mikroelektronika, jadi tidak mengejutkan bahwa CVD memainkan peran penting(150; 151). Perangkat MEMS dibuat dari film silikon polikristalin (polisilikon) disimpan pada wafer silikon, dengan perantara pengorbanan lapisan $\mathrm{SiO}$, yang kemudian dihapus oleh etsa kimia.sebuah contoh perangkat seperti itu, roda gigi yang berdiameter 50-200 mikron. Kedua polisilikon dan oksida disimpan menggunakan CVD atau PECVD. Langkah-langkah CVD menentukan struktur perangkat yang tegak lurus terhadap substrat silikon, sementara banyak litografi dan langkah etsa menentukan struktur di yang lain dua dimensi(3; 152-157). CVD kadang-kadang digunakan untuk menerapkan pelapis untuk mengurangi gesekan setelah 3-D struktur dibuat. Mengintegrasikan perangkat MEMS dengan silikon perangkat mikroelektronik pada chip yang sama. 
Bidang nanoteknologi telah dihasilkan banyak minat baru, dan penelitian terfokus program telah dimulai hampir semua negara industri dalam lima tahun terakhir. Di tahun 2000 AS meluncurkan National Nano- Inisiatif teknologi, dengan rencana untuk hampir dua kali lipat upaya R \& D berskala nano(21; 131; 149; 158-161). Nano-teknologi adalah topik yang sangat beragam, tetapi beberapa contoh terbaik dari R \& D nanoscale yang ada daerah heterostruktur epitaxial untuk laser dioda dan LED yang dikembangkan oleh CVD. Banyak dari perangkat ini mengandung dua dimensi (2-D) Sumur kuantum atau superlattices terdiri dari lapisan epitaxial tegang yang tebal 1-10 nm.Contoh.Selain sumur kuantum, struktur laser seperti permukaan rongga vertikal memancarkan laser (VCSEL) berisi tumpukan cermin terdiri dari sejumlah besar lapisan dengan bahan semikonduktor yang Tebal biasanya 50-100 nm(162-165). Ketebalan setiap lapisan seringkali harus dikontrol dengan presisi yang lebih baik dari $1 \mathrm{~nm}$.Meskipun persyaratan ini perangkat dapat tumbuh secara rutin dengan relatif hasil tinggi dalam OMVPE tersetel dan terkalibrasi reactor(62;113; 166; 167). Teknik CVD terkait itu secara otomatis menghasilkan kontrol subnanometer dikenal sebagai lapisan atom epitaxy (ALE).Perluasan 2-D quantum baik R \& D melibatkan generasi kabel kuantum (1-D) dan titik-titik kuantum (0-D). Quantum dots adalah sering dianggap sebagai atom buatan, di mana efek kurungan kuantum secara signifikan mengganggu sifat elektronik massal yang umum dari materi(6; 168-170). Salah satu metode pertumbuhan kuantum titik melibatkan penyetoran satu materi pada yang lain dengan ketidakcocokan kisi besar(171-173).

Aplikasi lainnya yaitu InAs on Gaas (100) oleh CVD. Disebabkan oleh sifat antarmuka yang sangat tegang layer, InAs secara spontan membentuk pulau di Skala 10-nm dengan ukuran distribusi yang relatif sempit $(13 ; 14 ; 31 ; 69)$. Elektronik dan optik properti dari titik-titik kuantum Inas adalah secara dramatis berbeda dari InAs massal, memungkinkan untuk fabrikasi perangkat baru.Selain banyak elektronik dan aplikasi optoelektronik yang disebutkan di atas, aplikasi baru CVD juga digunakan untuk menghasilkan komponen makroskopik $(10 \mathrm{~cm}$ sebagai lawan $1 \mathrm{~nm})$.Salah satu contoh yang menarik adalah produksi ruang dorong Ir / Re untuk cairan motor roket.Untuk struktur ini lapisan CVD rumen yang tebal diaplikasikan pada pengorbanan molibdenum mandrel, yang nantinya dihapus dengan etsa. Contoh lain adalah produksi bahan optik inframerah berskala besar ( $\mathrm{ZnSe}$ dan / atau $\mathrm{ZnS}$ hingga beberapa kaki)(174-176). ${ }_{32}$

Pemrosesan CVD suhu tinggi telah berkembang, dengan potensi besar untuk aplikasi komersial.Sebagai contoh, kelompok peneliti John Hart, seorang profesor teknik mesin, telah membangun sistem pemrosesan roll-to-roll menggunakan CVD untuk membuat lembaran graphene, bahan dengan aplikasi potensial mulai dari layar besar hingga penyaringan air $(121 ; 126 ; 177)$. sistem.Kelompok Hart dan lain-lain telah menggunakan CVD untuk menghasilkan array besar nanotube karbon, bahan dengan potensi sebagai elektroda baru untuk baterai atau sel bahan bakar(122; 178).

Deposisi uap kimia digunakan dalam banyak proses fabrikasi semikonduktor wafer, termasuk produksi film tipis amorf dan polikristalin (seperti silikon polikristalin), pengendapan $\mathrm{SiO}_{2}(\mathrm{CVD}$ $\mathrm{SiO}_{2}$ ) dan silikon nitrida, dan pertumbuhan kristal tunggal silikon lapisan epitaxial(174-176).

Pelapis CVD digunakan dalam banyak aplikasi manufaktur sebagai lapisan tahan aus: penggilingan karbida dan sisipan balik, komponen aus, beberapa alat pemroses plastik, dll. Namun, aplikasi yang paling umum untuk pelapisan CVD adalah untuk alat pembentuk logam.Lapisan CVD memberikan ketahanan yang sangat baik terhadap jenis aus dan menyakitkan yang biasanya terlihat selama banyak aplikasi pembentuk logam(151; 179-181).

Dalam aplikasi pembentuk logam tegangan tinggi, di mana toleransi alat dan izin substrat, proses pelapisan CVD suhu tinggi akan berkinerja lebih baik daripada proses "dingin" seperti PVD, krom padat-tipis (TDC), nitridasi, dll. Ikatan kimia / metalurgi yang hasil dari proses pelapisan CVD menciptakan karakteristik adhesi yang tidak dapat diduplikasi dengan proses "dingin". Adhesi yang ditingkatkan ini melindungi peralatan pembentuk dari gesekan gesekan yang diakibatkan oleh tekanan geser yang berat yang dihasilkan dalam aplikasi pembentuk logam berat $(131 ; 149 ; 162 ; 163 ; 182)$. 


\section{Reaksi Chemical Vapor Deposisi}

Selama proses deposisi uap kimia, gas-gas reaktan tidak hanya bereaksi dengan bahan substrat di permukaan wafer (atau sangat dekat dengannya), tetapi juga dalam fase gas di atmosfir reaktor. Reaksi yang terjadi di permukaan substrat dikenal sebagai reaksi heterogen, dan secara selektif terjadi pada permukaan wafer yang dipanaskan di mana mereka menciptakan film berkualitas baik(96; 97; $168 ; 183-186)$.

Reaksi yang terjadi dalam fase gas dikenal sebagai reaksi homogen . Reaksi homogen membentuk agregat fase gas dari material deposit, yang menempel ke permukaan dengan buruk dan pada saat yang sama membentuk film dengan kerapatan rendah dengan banyak cacat. Singkatnya, reaksi heterogen jauh lebih diinginkan daripada reaksi homogen selama deposisi uap kimia(61; 169; $170 ; 187 ; 188)$.

Deposisi uap kimia (CVD) adalah proses yang dikendalikan atmosfer yang dilakukan pada suhu tinggi $\left(\sim 1925^{\circ} \mathrm{F}\right)$ dalam reaktor CVD. Selama proses ini, lapisan film tipis terbentuk sebagai hasil reaksi antara berbagai fase gas dan permukaan substrat yang dipanaskan dalam reaktor CVD. Karena gas yang berbeda diangkut melalui reaktor, lapisan pelapis yang berbeda dibentuk pada substrat perkakas(120; 123-125).Misalnya, TiN terbentuk sebagai hasil reaksi kimia berikut:

$$
\mathrm{TiCl}_{4}+\mathrm{N}_{2}+\mathrm{H}_{2} \longrightarrow \mathrm{TiCl}+4 \mathrm{HCl}+\mathrm{H}_{2}
$$

Titanium carbide (TiC) dibentuk sebagai hasil reaksi kimia berikut:

$$
\mathrm{TiCl}_{4}+\mathrm{CH}_{4}+\mathrm{H}_{2} \longrightarrow \mathrm{TiCHB} 4 \mathrm{HCl}+\mathrm{H}_{2}
$$

Produk akhir dari reaksi ini adalah lapisan keras, tahan aus yang menunjukkan ikatan kimia dan metalurgi ke substrat(189-200).

\section{Kesimpulan}

Berdasarkan literatur dapat disimpulkan bahwa proses chemical vapor deposition merupakan metode deposisi yang digunakan untuk menghasilkan bahan padat berkualitas tinggi dan berkinerja tinggi yang biasanya dibawah vakum. Metode sol gel akan menghasilkan suatu material berupa berlian sintesis, thin film coating, lapisan emas dengan ketebalan yang tipis. Deposisi uap kimia (CVD) mengacu pada pembentukan film padat non-volatil pada substrat dari reaksi reaktan kimia fase uap yang mengandung konstituen yang tepat. Adapun aplikasi CVD antara lain digunakan untuk menghasilkan nanoscale, nanotubs, crystal, berlian, film lapisan tipis.(147; 148)

\section{Referensi}

1. Post P, Wurlitzer L, Maus-Friedrichs W, Weber AP. 2018. Characterization and Applications of Nanoparticles Modified in-Flight with Silica or Silica-Organic Coatings. Nanomaterials 8

2. Pour GB, Aval LF, Eslami S. 2018. Sensitive Capacitive-type Hydrogen Sensor Based on Ni Thin Film in Different Hydrogen Concentrations. Current nanoscience 14:136-42

3. Qi Y, Deng B, Guo X, Chen S, Gao J, et al. 2018. Switching Vertical to Horizontal Graphene Growth Using Faraday Cage-Assisted PECVD Approach for High-Performance Transparent Heating Device. Advanced materials 30

4. Qian Y, Kang DJ. 2018. Large-Area High-Quality AB-Stacked Bilayer Graphene on h-BN/Pt Foil by Chemical Vapor Deposition. ACS applied materials \& interfaces 10:29069-75 
5. Qin J, Wang C, Wang Y, Lu R, Zheng L, et al. 2018. Synthesis and growth mechanism of carbon nanotubes growing on carbon fiber surfaces with improved tensile strength. Nanotechnology 29:395602

6. Chen W, Xiao P, Chen H, Zhang H, Zhang Q, Chen Y. 2018. Polymeric Graphene Bulk Materials with a 3D Cross-Linked Monolithic Graphene Network. Advanced materials:e1802403

7. Perrotta A, Christian P, Jones AOF, Muralter F, Coclite AM. 2018. Growth Regimes of Poly(perfluorodecyl acrylate) Thin Films by Initiated Chemical Vapor Deposition. Macromolecules 51:5694-703

8. Petroski K, Poges S, Monteleone C, Grady J, Bhatt R, Suib SL. 2018. Rapid Chemical Vapor Infiltration of Silicon Carbide Minicomposites at Atmospheric Pressure. ACS applied materials \& interfaces 10:498692

9. Piquemal-Banci M, Galceran R, Godel F, Caneva S, Martin MB, et al. 2018. Insulator-to-Metallic SpinFiltering in 2D-Magnetic Tunnel Junctions Based on Hexagonal Boron Nitride. ACS nano 12:4712-8

10. Zhang M, Guo Z, Zhao L, Yang S, Zhao L. 2018. The Effect of Buffer Types on the In0.82Ga0.18As Epitaxial Layer Grown on an InP (100) Substrate. Materials 11

11. Zhang S, Liu J, Ruiz KH, Tu R, Yang M, et al. 2018. Morphological Evolution of Vertically Standing Molybdenum Disulfide Nanosheets by Chemical Vapor Deposition. Materials 11

12. Zhang X, Choudhury TH, Chubarov M, Xiang Y, Jariwala B, et al. 2018. Diffusion-Controlled Epitaxy of Large Area Coalesced WSe2 Monolayers on Sapphire. Nano letters 18:1049-56

13. Yang P, Zou X, Zhang Z, Hong M, Shi J, et al. 2018. Batch production of 6-inch uniform monolayer molybdenum disulfide catalyzed by sodium in glass. Nature communications 9:979

14. Yang X, Du W, Ji X, Zhang X, Yang T. 2018. Defect-free InAsSb nanowire arrays on Si substrates grown by selective-area metal-organic chemical vapor deposition. Nanotechnology 29:405601

15. Ye R, James DK, Tour JM. 2018. Laser-Induced Graphene. Accounts of chemical research 51:1609-20

16. Jiang S, Hou PX, Chen ML, Wang BW, Sun DM, et al. 2018. Ultrahigh-performance transparent conductive films of carbon-welded isolated single-wall carbon nanotubes. Science advances 4:eaap9264

17. Komane PP, Kumar P, Marimuthu T, Toit LCD, Kondiah PPD, et al. 2018. Dexamethasone-Loaded, PEGylated, Vertically Aligned, Multiwalled Carbon Nanotubes for Potential Ischemic Stroke Intervention. Molecules 23

18. Krishna VM, Somanathan T, Manikandan E, Tadi KK, Uvarajan S. 2018. Neurotransmitter Dopamine Enhanced Sensing Detection Using Fibre-Like Carbon Nanotubes by Chemical Vapor Deposition Technique. Journal of nanoscience and nanotechnology 18:5380-9

19. Ahmet IY, Hill MS, Raithby PR, Johnson AL. 2018. Tin guanidinato complexes: oxidative control of Sn, SnS, SnSe and SnTe thin film deposition. Dalton transactions 47:5031-48

20. Bitencourt SB, Dos Santos DM, da Silva EVF, Barao VAR, Rangel EC, et al. 2018. Characterisation of a new plasma-enhanced film to improve shear bond strength between zirconia and veneering ceramic. Materials science \& engineering. C, Materials for biological applications 92:196-205

21. Black A, Urbanos FJ, Osorio MR, Miranda R, Vazquez de Parga AL, Granados D. 2018. Encapsulating Chemically Doped Graphene via Atomic Layer Deposition. ACS applied materials \& interfaces 10:81906

22. Uchida Y, Nakandakari S, Kawahara K, Yamasaki S, Mitsuhara M, Ago H. 2018. Controlled Growth of Large-Area Uniform Multilayer Hexagonal Boron Nitride as an Effective 2D Substrate. ACS nano

23. Vangala S, Siegel G, Prusnick T, Snure M. 2018. Wafer scale BN on sapphire substrates for improved graphene transport. Scientific reports 8:8842

24. Vos R, Rolin C, Rip J, Conard T, Steylaerts T, et al. 2018. Chemical Vapor Deposition of Azidoalkylsilane Monolayer Films. Langmuir : the ACS journal of surfaces and colloids 34:1400-9

25. Wu Y, Li F, Chen W, Xiang Q, Ma Y, et al. 2018. Coupling Interface Constructions of MoS2 /Fe5 Ni4 S8 Heterostructures for Efficient Electrochemical Water Splitting. Advanced materials:e1803151

26. Xie H, Gu Y, Mu H. 2018. Photocatalytic Performance of 3D Ni/Graphene/ZnO Composites Fabricated by Hydrothermal Processing. Journal of nanoscience and nanotechnology 18:4822-33

27. Xing X, Wang H, Xiao G, Yang S, Shu X. 2018. Assessment of titanium metallization thin film deposited on alumina substrate: Microstructure and nano-indentation. Journal of the mechanical behavior of biomedical materials 80:235-45 
28. Wang X, Sheng Y, Chang RJ, Lee JK, Zhou Y, et al. 2018. Chemical Vapor Deposition Growth of TwoDimensional Monolayer Gallium Sulfide Crystals Using Hydrogen Reduction of Ga2S3. ACS omega 3:7897-903

29. Wang Z, Shen Y, Ito Y, Zhang Y, Du J, et al. 2018. Synthesizing 1T-1H Two-Phase Mo1-xWxS2 Monolayers by Chemical Vapor Deposition. ACS nano 12:1571-9

30. Wu H, Zhou X, Li J, Li X, Li B, et al. 2018. Ultrathin Molybdenum Dioxide Nanosheets as Uniform and Reusable Surface-Enhanced Raman Spectroscopy Substrates with High Sensitivity. Small:e1802276

31. Yang ZD, Yang XY, Liu T, Chang ZW, Yin YB, et al. 2018. In Situ CVD Derived Co-N-C Composite as Highly Efficient Cathode for Flexible Li-O2 Batteries. Small:e1800590

32. Chiappe D, Ludwig J, Leonhardt A, El Kazzi S, Nalin Mehta A, et al. 2018. Layer-controlled epitaxy of 2D semiconductors: bridging nanoscale phenomena to wafer-scale uniformity. Nanotechnology 29:425602

33. Chin HT, Lee JJ, Hofmann M, Hsieh YP. 2018. Impact of growth rate on graphene lattice-defect formation within a single crystalline domain. Scientific reports 8:4046

34. Cho S, Jung I, Jang HJ, Liu L, Park S. 2018. Bimetallic junction mediated synthesis of multilayer graphene edges towards ultrahigh capacity for lithium ion batteries. Nanoscale 10:5214-20

35. Dechamps S, Nguyen VH, Charlier JC. 2018. Ab initio quantum transport in polycrystalline graphene. Nanoscale 10:7759-68

36. Munoz-Sandoval E, Fajardo-Diaz JL, Sanchez-Salas R, Cortes-Lopez AJ, Lopez-Urias F. 2018. Two Sprayer CVD Synthesis of Nitrogen-doped Carbon Sponge-type Nanomaterials. Scientific reports 8:2983

37. Murthy AA, Li Y, Palacios E, Li Q, Hao S, et al. 2018. Optically Active 1D MoS2 Nanobelts. ACS applied materials \& interfaces 10:6799-804

38. Liu J, Ye J, Li Z, Otake KI, Liao Y, et al. 2018. Beyond the Active Site: Tuning the Activity and Selectivity of a Metal-Organic Framework-Supported Ni Catalyst for Ethylene Dimerization. Journal of the American Chemical Society 140:11174-8

39. Majewski GP, Rodan K, Fields K, Falla TJ. 2018. Characterization of bound water in skin hydrators prepared with and without a 3D3P interpenetrating polymer network. Skin research and technology: official journal of International Society for Bioengineering and the Skin

40. Malkin AD, Ye SH, Lee EJ, Yang X, Zhu Y, et al. 2018. Development of zwitterionic sulfobetaine block copolymer conjugation strategies for reduced platelet deposition in respiratory assist devices. Journal of biomedical materials research. Part B, Applied biomaterials

41. Rahman R, Klesko JP, Dangerfield A, Mattson EC, Chabal YJ. 2018. Selective Growth of Interface Layers from Reactions of Sc(MeCp)2(Me2pz) with Oxide Substrates. ACS applied materials \& interfaces

42. Salzmann P, Perrotta A, Coclite AM. 2018. Different Response Kinetics to Temperature and Water Vapor of Acrylamide Polymers Obtained by Initiated Chemical Vapor Deposition. ACS applied materials \& interfaces 10:6636-45

43. Sojoudi H, Arabnejad H, Raiyan A, Shirazi SA, McKinley GH, Gleason KK. 2018. Scalable and durable polymeric icephobic and hydrate-phobic coatings. Soft matter 14:3443-54

44. Su L, Smith PM, Anand P, Reeja-Jayan B. 2018. Surface Engineering of a LiMn2O4 Electrode Using Nanoscale Polymer Thin Films via Chemical Vapor Deposition Polymerization. ACS applied materials \& interfaces 10:27063-73

45. X Li LC, RS Ruoff. 2016. Synthesis of Graphene Films on Copper Foils by Chemical Vapor Deposition.

46. X Ling YL, Y Lin, W Fang, L Yu. 2014. Role of the Seeding Promoter in MoS2 Growth by Chemical Vapor Deposition.

47. M Ma YM, M Gupta, KK Gleason. 2005. Superhydrophobic fabrics produced by electrospinning and chemical vapor deposition.

48. X Li CM, A Venugopal. 2011. Large-area graphene single crystals grown by low-pressure chemical vapor deposition of methane on copper.

49. YH Lee XZ, W Zhang, MT Chang. 2012. Synthesis of Large- Area MoS2 Atomic Layers with Chemical Vapor Deposition.

50. Z Z Wang YS, Y Ito, Y Zhang, J Du, T Fujita. 2018. Synthesizing 1T-1H Two-Phase Mo1-xWxS2 Monolayers by Chemical Vapor Deposition. 
51. X Zhou LG, W Tian, Q Zhang, S Jin, H Li. 2015. Ultrathin SnSe2 Flakes Grown by Chemical Vapor Deposition for High- Performance Photodetectors.

52. WZ Xu ZY, YJ Zeng, LP Zhu, BH Zhao. 2006. ZnO light-emitting diode grown by plasma-assisted metal organic chemical vapor deposition.

53. Zhao L, Shang Q, Gao Y, Shi J, Liu Z, et al. 2018. High-Temperature Continuous-Wave Pumped Lasing from Large-Area Monolayer Semiconductors Grown by Chemical Vapor Deposition. ACS nano

54. Zheng Q, Zhou W, Peng Y, Yin Y, Zhong M, et al. 2018. Surface polarons and optical micro-cavity modulated broad range multi-modes emission of Te-doped CdS nanowires. Nanotechnology

55. Zhou Q, Su S, Hu D, Lin L, Yan Z, et al. 2018. Ultra-thin MoS<sub $>2</$ sub $>$ coated Ag@ Si nanosphere arrays as efficient and stable photocathode for solar-driven hydrogen production. Nanotechnology

56. Zhou Q, Su S, Hu D, Lin L, Yan Z, et al. 2018. Ultrathin MoS2-coated Ag@Si nanosphere arrays as an efficient and stable photocathode for solar-driven hydrogen production. Nanotechnology 29:105402

57. Zhou Y, Tan H, Sheng Y, Fan Y, Xu W, Warner JH. 2018. Utilizing Interlayer Excitons in Bilayer WS2 for Increased Photovoltaic Response in Ultrathin Graphene Vertical Cross-Bar Photodetecting Tunneling Transistors. ACS nano 12:4669-77

58. X Wang HF, Y Wu, L Jiao. 2013. Controlled Synthesis of Highly Crystalline MoS2 Flakes by Chemical Vapor Deposition.

59. B Xiang PW, X Zhang, SA Dayeh, DPR Aplin. 2007. Rational synthesis of p-type zinc oxide nanowire arrays using simple chemical vapor deposition.

60. Cayzac W, Pomorski M, Blazevic A, Canaud B, Deslandes D, et al. 2018. CVD diamond detector with interdigitated electrode pattern for time-of-flight energy-loss measurements of low-energy ion bunches. The Review of scientific instruments 89:053301

61. Dong R, Zhang T, Feng X. 2018. Interface-Assisted Synthesis of 2D Materials: Trend and Challenges. Chemical reviews 118:6189-235

62. Dou W, Benamara M, Mosleh A, Margetis J, Grant P, et al. 2018. Investigation of GeSn Strain Relaxation and Spontaneous Composition Gradient for Low-Defect and High-Sn Alloy Growth. Scientific reports 8:5640

63. Fan X, Wagner S, Schadlich P, Speck F, Kataria S, et al. 2018. Direct observation of grain boundaries in graphene through vapor hydrofluoric acid (VHF) exposure. Science advances 4:eaar5170

64. Fang X, Wei P, Wang L, Wang X, Chen B, et al. 2018. Transforming Monolayer Transition-Metal Dichalcogenide Nanosheets into One-Dimensional Nanoscrolls with High Photosensitivity. ACS applied materials \& interfaces 10:13011-8

65. Manawi YM, Ihsanullah, Samara A, Al-Ansari T, Atieh MA. 2018. A Review of Carbon Nanomaterials' Synthesis via the Chemical Vapor Deposition (CVD) Method. Materials 11

66. Manuel JM, Jimenez JJ, Morales FM, Lacroix B, Santos AJ, et al. 2018. Engineering of III-Nitride Semiconductors on Low Temperature Co-fired Ceramics. Scientific reports 8:6879

67. Martella C, Mennucci C, Lamperti A, Cappelluti E, de Mongeot FB, Molle A. 2018. Designer Shape Anisotropy on Transition-Metal-Dichalcogenide Nanosheets. Advanced materials 30

68. LG De Arco YZ, A Kumar. 2009. Synthesis, transfer, and devices of single-and few-layer graphene by chemical vapor deposition.

69. Yang ZX, Yin Y, Sun J, Bian L, Han N, et al. 2018. Chalcogen passivation: an in-situ method to manipulate the morphology and electrical property of GaAs nanowires. Scientific reports 8:6928

70. A Reina XJ, J Ho, D Nezich, H Son, V Bulovic. 2008. Large area, few-layer graphene films on arbitrary substrates by chemical vapor deposition.

71. Cheng Z, Bougher T, Bai T, Wang SY, Li C, et al. 2018. Probing Growth-Induced Anisotropic Thermal Transport in High-Quality CVD Diamond Membranes by Multifrequency and Multiple-Spot-Size TimeDomain Thermoreflectance. ACS applied materials \& interfaces 10:4808-15

72. Gebbie MA, Ishiwata H, McQuade PJ, Petrak V, Taylor A, et al. 2018. Experimental measurement of the diamond nucleation landscape reveals classical and nonclassical features. Proceedings of the National Academy of Sciences of the United States of America 115:8284-9

73. Rani R, Panda K, Kumar N, Titovich KA, Ivanovich KV, et al. 2018. Tribological Properties of Ultrananocrystalline Diamond Films: Mechanochemical Transformation of Sliding Interfaces. Scientific reports 8:283 
74. Rydygier M, Jastrzab M, Krzempek D, Nowak T, Grzanka L, et al. 2018. RADIOTHERAPY PROTON BEAM PROFILOMETRY WITH scCVD DIAMOND DETECTOR IN SINGLE PARTICLE MODE. Radiation protection dosimetry 180:282-5

75. Sankaran KJ, Ficek M, Kunuku S, Panda K, Yeh CJ, et al. 2018. Self-organized multi-layered grapheneboron-doped diamond hybrid nanowalls for high-performance electron emission devices. Nanoscale 10:1345-55

76. Yang B, Molina E, Kim J, Barroso D, Lohmann M, et al. 2018. Effect of Distance on Photoluminescence Quenching and Proximity-Induced Spin-Orbit Coupling in Graphene/WSe2 Heterostructures. Nano letters 18:3580-5

77. Yang L, Mao Y, Jansz J. 2018. Chinese Urban Hui Muslims' Access to and Evaluation of Cardiovascular Diseases-Related Health Information from Different Sources. International journal of environmental research and public health 15

78. Ershov KS, Kochubei SA, Kiselev VG, Baklanov AV. 2018. Decomposition Pathways of Titanium Isopropoxide $\mathrm{Ti}(\mathrm{O}(\mathrm{i}) \mathrm{Pr}) 4$ : New Insights from UV-Photodissociation Experiments and Quantum Chemical Calculations. The journal of physical chemistry. A 122:1064-70

79. Filatova EA, Hausmann D, Elliott SD. 2018. Understanding the Mechanism of SiC Plasma-Enhanced Chemical Vapor Deposition (PECVD) and Developing Routes toward SiC Atomic Layer Deposition (ALD) with Density Functional Theory. ACS applied materials \& interfaces 10:15216-25

80. Gao Z, Ji Q, Shen PC, Han Y, Leong WS, et al. 2018. In-situ Generated Volatile Precursor for CVD Growth of a Semimetallic 2D Dichalcogenide. ACS applied materials \& interfaces

81. Qiu L, Dong JC, Ding F. 2018. Selective growth of two-dimensional phosphorene on catalyst surface. Nanoscale 10:2255-9

82. Qiu Z, Li P, Li Z, Yang J. 2018. Atomistic Simulations of Graphene Growth: From Kinetics to Mechanism. Accounts of chemical research 51:728-35

83. Zainul R. 2015. Disain dan Modifikasi Kolektor dan Reflektor Cahaya pada Panel Sel Surya Al/Cu2O-Gel Na2SO4. Project Report

84. Zainul R. 2018. Photoelectrosplitting Water Mechanism at Carbon Electrode Surface using Indoor lights. CC-By Attribution 4.0 International

85. Zainul R. 2018. Design and Modification of Copper Oxide Electrodes for Improving Conversion Coefficient Indoors Lights (PV-Cell) Photocells. CC-By Attribution 4.0 International

86. Lim YF, Priyadarshi K, Bussolotti F, Gogoi PK, Cui X, et al. 2018. Modification of Vapor Phase Concentrations in MoS2 Growth Using a NiO Foam Barrier. ACS nano 12:1339-49

87. Lin YC, Jariwala B, Bersch BM, Xu K, Nie Y, et al. 2018. Realizing Large-Scale, Electronic-Grade TwoDimensional Semiconductors. ACS nano 12:965-75

88. Martin AA, Depond PJ. 2018. Formation mechanisms of boron oxide films fabricated by large-area electron beam-induced deposition of trimethyl borate. Beilstein journal of nanotechnology 9:1282-7

89. Mochalov L, Dorosz D, Kudryashov M, Nezhdanov A, Usanov D, et al. 2018. Infrared and Raman spectroscopy study of AsS chalcogenide films prepared by plasma-enhanced chemical vapor deposition. Spectrochimica acta. Part A, Molecular and biomolecular spectroscopy 193:258-63

90. Wang S, Ji X, Ao Y, Yu J. 2018. Vertically Aligned N-Doped Diamond/Graphite Hybrid Nanosheets Epitaxially Grown on B-Doped Diamond Films as Electrocatalysts for Oxygen Reduction Reaction in an Alkaline Medium. ACS applied materials \& interfaces 10:29866-75

91. Wang S, Ji X, Ao Y, Yu J. 2018. Substrate-orientation dependent epitaxial growth of highly ordered diamond nanosheet arrays by chemical vapor deposition. Nanoscale 10:2812-9

92. Wang T, Handschuh-Wang S, Huang L, Zhang L, Jiang X, et al. 2018. Controlling Directional Liquid Motion on Micro- and Nanocrystalline Diamond/beta-SiC Composite Gradient Films. Langmuir : the ACS journal of surfaces and colloids 34:1419-28

93. Xiang J, Pang S, Xie L, Gao F, Hu X, et al. 2018. Mechanism-Based FE Simulation of Tool Wear in Diamond Drilling of SiCp/Al Composites. Materials 11

94. Tchouaso MT, Kasiwattanawut H, Prelas MA. 2018. Energy response of diamond sensor to beta radiation. Applied radiation and isotopes : including data, instrumentation and methods for use in agriculture, industry and medicine 139:66-9 
95. Duncombe TA, Raad M, Bowen BP, Singh AK, Northen TR. 2018. Insulator Nanostructure Desorption Ionization Mass Spectrometry. Analytical chemistry 90:9657-61

96. Durkan C. 2018. Periodic ripples on thermally-annealed graphene on $\mathrm{Cu}$ (110)-reconstruction or moire pattern? Nanotechnology 29:455705

97. E S, Li C, Li T, Geng R, Li Q, et al. 2018. Ammonium-tungstate-promoted growth of boron nitride nanotubes. Nanotechnology 29:195604

98. Giese A, Schipporeit S, Buck V, Wohrl N. 2018. Synthesis of carbon nanowalls from a single-source metal-organic precursor. Beilstein journal of nanotechnology 9:1895-905

99. Halbig CE, Martin O, Hauke F, Eigler S, Hirsch A. 2018. Oxo-Functionalized Graphene: A Versatile Precursor for Alkylated Graphene Sheets by Reductive Functionalization. Chemistry

100. Hong Y, Choi IA, Seo WS. 2018. Au nanoparticle@ hollow mesoporous carbon with FeCo/graphitic shell nanoparticls as a magnetically recyclable yolk-shell nanocatalyst for catalytic reduction of nitroaromatics. Scientific reports 8:7469

101. Imam M, Hoglund C, Schmidt S, Hall-Wilton R, Birch J, Pedersen H. 2018. Plasma CVD of hydrogenated boron-carbon thin films from triethylboron. The Journal of chemical physics 148:034701

102. Journot T, Bouchiat V, Gayral B, Dijon J, Hyot B. 2018. Self-Assembled UV Photodetector Made by Direct Epitaxial GaN Growth on Graphene. ACS applied materials \& interfaces 10:18857-62

103. Junge Puring K, Zywitzki D, Taffa DH, Rogalla D, Winter M, et al. 2018. Rational Development of Cobalt beta-Ketoiminate Complexes: Alternative Precursors for Vapor-Phase Deposition of Spinel Cobalt Oxide Photoelectrodes. Inorganic chemistry 57:5133-44

104. Khan MD, Aamir M, Sohail M, Sher M, Baig N, et al. 2018. Bis(selenobenzoato)dibutyltin(iv) as a single source precursor for the synthesis of $\mathrm{SnSe}$ nanosheets and their photo-electrochemical study for water splitting. Dalton transactions 47:5465-73

105. Kim EH, Lim MH, Lah MS, Koo SM. 2018. Synthesis and characterization of heteroleptic titanium MOCVD precursors for TiO2 thin films. Dalton transactions 47:2415-21

106. Kim H, Ren D, Farrell AC, Huffaker DL. 2018. Catalyst-free selective-area epitaxy of GaAs nanowires by metal-organic chemical vapor deposition using triethylgallium. Nanotechnology 29:085601

107. Oyelade A, Yost AJ, Benker N, Dong B, Knight S, et al. 2018. Composition-dependent charge transport in boron carbides alloyed with aromatics: PECVD aniline/orthocarborane films. Langmuir : the ACS journal of surfaces and colloids

108. Park JM, Jang SJ, Lee SI, Lee WJ. 2018. Novel Cyclosilazane-Type Silicon Precursor and Two-Step Plasma for Plasma-Enhanced Atomic Layer Deposition of Silicon Nitride. ACS applied materials \& interfaces 10:9155-63

109. Feng H, Jia Y, Shen D, Zhou Y, Chen T, et al. 2018. The effect of chemical vapor deposition temperature on the performance of binder-free sewage sludge-derived anodes in microbial fuel cells. The Science of the total environment 635:45-52

110. Farhanian D, De Crescenzo G, Tavares JR. 2018. Large-Scale Encapsulation of Magnetic Iron Oxide Nanoparticles via Syngas Photo-Initiated Chemical Vapor Deposition. Scientific reports 8:12223

111. Fabbiani M, Pazzi M, Vincenti M, Tabacch G, Fois E, Martra G. 2018. Does the Abiotic Formation of Oligopeptides on $\mathrm{TiO}(2)$ Nanoparticles Require Special Catalytic Sites? Apparently Not. Journal of nanoscience and nanotechnology 18:5854-7

112. Ellsworth AA, Walker AV. 2018. Effect of Ethanolamines on the Electroless Deposition of Copper on Functionalized Organic Surfaces. Langmuir : the ACS journal of surfaces and colloids 34:4142-9

113. Du L, Yang L, Hu Z, Zhang J, Huang C, et al. 2018. Thickness-controlled direct growth of nanographene and nanographite film on non-catalytic substrates. Nanotechnology 29:215711

114. Zeng M, Fu L. 2018. Controllable Fabrication of Graphene and Related Two-Dimensional Materials on Liquid Metals via Chemical Vapor Deposition. Accounts of chemical research

115. Zemlyanov DY, Jespersen M, Zakharov DN, Hu J, Paul R, et al. 2018. Versatile technique for assessing thickness of 2D layered materials by XPS. Nanotechnology 29:115705

116. Yu SH, Chua DHC. 2018. Toward High-Performance and Low-Cost Hydrogen Evolution Reaction Electrocatalysts: Nanostructuring Cobalt Phosphide (CoP) Particles on Carbon Fiber Paper. ACS applied materials \& interfaces 10:14777-85 
117. Yao H, Liu L, Wang Z, Li H, Chen L, et al. 2018. Significant photoluminescence enhancement in WS2 monolayers through Na2S treatment. Nanoscale 10:6105-12

118. Yao Z, Liu J, Xu K, Chow EKC, Zhu W. 2018. Material Synthesis and Device Aspects of Monolayer Tungsten Diselenide. Scientific reports 8:5221

119. Yao Z, Xia X, Zhou CA, Zhong Y, Wang Y, et al. 2018. Smart Construction of Integrated CNTs/Li4Ti5O12 Core/Shell Arrays with Superior High-Rate Performance for Application in LithiumIon Batteries. Advanced science 5:1700786

120. Rahadian Zainul AA, Hermansyah Aziz, Syukri Arief, Syukri, Edison Munaf. 2015. Design of Photovoltaic Cell with Copper Oxide Electrode by using Indoor Lights. Research Journal of Pharmaceutical Biological and Chemical Science

121. R Zainul BO, I Dewata, J Efendi. 2018. Thermal and Surface Evaluation on The Process of Forming a $\mathrm{Cu} 2 \mathrm{O} / \mathrm{CuO}$ Semiconductor Photocatalyst on a Thin Copper Plate. IOP Conference Series: Materials Science and Engineering

122. Arif Yasthopi Rahadian Zainul AA, Hermansyah Aziz, Syukri Arief, Syukri. 2015. Photoelectrosplitting Water for Hydrogen Production Using Illumination with Indoor Lights. Journal of Chemical and Pharmaceutical Research

123. Zainul R. 2015. Disain dan Modifikasi Kolektor dan Reflektor Cahaya pada Panel Sel Surya Al/Cu2O-Gel $\mathrm{Na} 2 \mathrm{SO} 4$. Research Report

124. Rahadian Zainul AA, Hermansyah Aziz, Syukri Arief, Syukri Darajat. 2015. Modifikasi dan Karakteristik I-V Sel Fotovoltaik Cu2O/Cu-Gel Na2SO4 Melalui Illuminasi Lampu Neon. EKSAKTA Berkala Ilmiah Bidang MIPA

125. Rahadian Zainul AA, Hermansyah Aziz, Syukri Arief, Syukri Darajat. 2015. Disain Geometri Reaktor Fotosel Cahaya Ruang. Jurnal Riset Kimia

126. M Mawardi DD, R Zainul. 2018. Characterization of PCC Cement by Addition of Napa Soil from Subdistrict Sarilamak 50 Kota District as Alternative Additional Material for Semen Padang. IOP Conference Series: Materials Science and Engineering

127. Kim SJ, Kwon O, Kim DW, Kim J, Jung HT. 2018. Influence of graphene thickness and grain boundaries on MoS2 wrinkle nanostructures. Physical chemistry chemical physics : PCCP 20:17000-8

128. Kim SJ, Shin DH, Choi YS, Rho H, Park M, et al. 2018. Ultrastrong Graphene-Copper Core-Shell Wires for High-Performance Electrical Cables. ACS nano 12:2803-8

129. Kim YC, Nguyen VT, Lee S, Park JY, Ahn YH. 2018. Evaluation of Transport Parameters in MoS2/Graphene Junction Devices Fabricated by Chemical Vapor Deposition. ACS applied materials \& interfaces 10:5771-8

130. Kovalska E, Pavlov I, Deminskyi P, Baldycheva A, Ilday FO, Kocabas C. 2018. NLL-Assisted Multilayer Graphene Patterning. ACS omega 3:1546-54

131. Barreca D, Bigiani L, Monai M, Carraro G, Gasparotto A, et al. 2018. Supported Mn3O4 Nanosystems for Hydrogen Production through Ethanol Photoreforming. Langmuir : the ACS journal of surfaces and colloids 34:4568-74

132. Barry ST, Teplyakov AV, Zaera F. 2018. The Chemistry of Inorganic Precursors during the Chemical Deposition of Films on Solid Surfaces. Accounts of chemical research 51:800-9

133. Bautista-Gomez J, Forzano AV, Austin JM, Collinson MM, Higgins DA. 2018. Vapor-Phase Plotting of Organosilane Chemical Gradients. Langmuir : the ACS journal of surfaces and colloids 34:9665-72

134. Kwon YH, Kumar S, Bae J, Seo Y. 2018. CVD-graphene for low equivalent series resistance in rGO/CVD-graphene/Ni-based supercapacitors. Nanotechnology 29:195404

135. Leardini F, Flores E, Galvis EA, Ferrer IJ, Ares JR, et al. 2018. Chemical vapor deposition growth of boron-carbon-nitrogen layers from methylamine borane thermolysis products. Nanotechnology 29:025603

136. Lee E, Lee SG, Lee HC, Jo M, Yoo MS, Cho K. 2018. Direct Growth of Highly Stable Patterned Graphene on Dielectric Insulators using a Surface-Adhered Solid Carbon Source. Advanced materials 30:e1706569

137. Lee HC, Bong H, Yoo MS, Jo M, Cho K. 2018. Copper-Vapor-Assisted Growth and Defect-Healing of Graphene on Copper Surfaces. Small 14:e1801181 
138. Mochalov L, Dorosz D, Nezhdanov A, Kudryashov M, Zelentsov S, et al. 2018. Investigation of the composition-structure-property relationship of AsxTe100-x films prepared by plasma deposition. Spectrochimica acta. Part A, Molecular and biomolecular spectroscopy 191:211-6

139. Mi Y, Liu Z, Shang Q, Niu X, Shi J, et al. 2018. Fabry-Perot Oscillation and Room Temperature Lasing in Perovskite Cube-Corner Pyramid Cavities. Small 14

140. Megalini L, Suran Brunelli ST, Charles WO, Taylor A, Isaac B, et al. 2018. Strain-Compensated InGaAsP Superlattices for Defect Reduction of InP Grown on Exact-Oriented (001) Patterned Si Substrates by Metal Organic Chemical Vapor Deposition. Materials 11

141. Liao Y, Jiang H, Wei N, Laiho P, Zhang Q, et al. 2018. Direct Synthesis of Colorful Single-Walled Carbon Nanotube Thin Films. Journal of the American Chemical Society 140:9797-800

142. Li Z, E R, Lu C, Prakoso AB, Foldyna M, et al. 2018. Optical Study and Experimental Realization of Nanostructured Back Reflectors with Reduced Parasitic Losses for Silicon Thin Film Solar Cells.

Nanomaterials 8

143. Chen Y, Huang S, Ji X, Adepalli K, Yin K, et al. 2018. Tuning Electronic Structure of Single Layer MoS2 through Defect and Interface Engineering. ACS nano 12:2569-79

144. Chen Z, Zhang X, Dou Z, Wei T, Liu Z, et al. 2018. High-Brightness Blue Light-Emitting Diodes Enabled by a Directly Grown Graphene Buffer Layer. Advanced materials 30:e1801608

145. Cho DH, Lee WJ, Wi JH, Han WS, Yun SJ, et al. 2018. Enhanced sulfurization reaction of molybdenum using a thermal cracker for forming two-dimensional MoS2 layers. Physical chemistry chemical physics : PCCP 20:16193-201

146. Bahariqushchi R, Raciti R, Kasapoglu AE, Gur E, Sezen M, et al. 2018. Stress evolution of Ge nanocrystals in dielectric matrices. Nanotechnology 29:185704

147. Baig N, Saleh TA. 2018. Electrodes modified with 3D graphene composites: a review on methods for preparation, properties and sensing applications. Mikrochimica acta 185:283

148. Baker PA, Catledge SA, Harris SB, Ham KJ, Chen WC, et al. 2018. Computational Predictions and Microwave Plasma Synthesis of Superhard Boron-Carbon Materials. Materials 11

149. Bang K, Chee SS, Kim K, Son M, Jang H, et al. 2018. Effect of ribbon width on electrical transport properties of graphene nanoribbons. Nano convergence 5:7

150. Tian B, Li HF, Yang H, Song DL, Bai XW, Zhao YL. 2018. A MEMS SOI-based piezoresistive fluid flow sensor. The Review of scientific instruments 89:025001

151. Xiang R, Maruyama S. 2018. Revisiting behaviour of monometallic catalysts in chemical vapour deposition synthesis of single-walled carbon nanotubes. Royal Society open science 5:180345

152. Wu CH, Chang KM, Chen YM, Huang BW, Zhang YX, Wang SJ. 2018. Using KrF ELA to Improve Gate-Stacked $\mathrm{LaAlO}(3) / \mathrm{ZrO}(2)$ Indium Gallium Zinc Oxide Thin-Film Transistors with Novel Atmospheric Pressure Plasma-Enhanced Chemical Vapor Deposition Technique. Journal of nanoscience and nanotechnology 18:1917-21

153. Wong MS, Hwang D, Alhassan AI, Lee C, Ley R, et al. 2018. High efficiency of III-nitride micro-lightemitting diodes by sidewall passivation using atomic layer deposition. Optics express 26:21324-31

154. Wang Y, Liu H, Shen W. 2018. A Convenient and Effective Method to Deposit Low-Defect-Density ncSi:H Thin Film by PECVD. Nanoscale research letters 13:234

155. Wang X, Li Q, Zhang L, Hu Z, Yu L, et al. 2018. Caging Nb2 O5 Nanowires in PECVD-Derived Graphene Capsules toward Bendable Sodium-Ion Hybrid Supercapacitors. Advanced materials 30:e1800963

156. Wang X, Li C, Chi Y, Piao M, Chu J, et al. 2018. Effect of Graphene Nanowall Size on the Interfacial Strength of Carbon Fiber Reinforced Composites. Nanomaterials 8

157. Song P, Chen C, Qu J, Ou P, Dastjerdi MHT, et al. 2018. Rolled-up SiO x /SiN x microtubes with an enhanced quality factor for sensitive solvent sensing. Nanotechnology 29:415501

158. Baysal M, Bilge K, Yildizhan MM, Yorulmaz Y, Oncel C, et al. 2018. Catalytic synthesis of boron nitride nanotubes at low temperatures. Nanoscale 10:4658-62

159. Bekduz B, Beckmann Y, Mischke J, Twellmann J, Mertin W, Bacher G. 2018. Graphene growth through a recrystallization process in plasma enhanced chemical vapor deposition. Nanotechnology 29:455603

160. Bellus MZ, Mahjouri-Samani M, Lane SD, Oyedele AD, Li X, et al. 2018. Photocarrier Transfer across Monolayer MoS2-MoSe2 Lateral Heterojunctions. ACS nano 12:7086-92 
161. Braeuninger-Weimer P, Funke S, Wang R, Thiesen P, Tasche D, et al. 2018. Fast, Noncontact, WaferScale, Atomic Layer Resolved Imaging of Two-Dimensional Materials by Ellipsometric Contrast Micrography. ACS nano 12:8555-63

162. Bu F, Chen W, Gu J, Agboola PO, Al-Khalli NF, et al. 2018. Microwave-assisted CVD-like synthesis of dispersed monolayer/few-layer N-doped graphene encapsulated metal nanocrystals for efficient electrocatalytic oxygen evolution. Chemical science 9:7009-16

163. Bukhtiar A, BingSuo Z. 2018. The Preparation and Optical Properties of Ni(II) and Mn(II) Doped in ZnTe Nanobelt/Nanorod by Using Chemical Vapor Deposition. Journal of nanoscience and nanotechnology 18:4700-13

164. Cai L, Shearer MJ, Zhao Y, Hu Z, Wang F, et al. 2018. Chemically Derived Kirigami of WSe2. Journal of the American Chemical Society 140:10980-7

165. Chang HC, Tu CL, Lin KI, Pu J, Takenobu T, et al. 2018. Synthesis of Large-Area InSe Monolayers by Chemical Vapor Deposition. Small:e1802351

166. Drieschner S, Seckendorff MV, Corro ED, Wohlketzetter J, Blaschke BM, et al. 2018. Uniformly coated highly porous graphene/MnO2 foams for flexible asymmetric supercapacitors. Nanotechnology 29:225402

167. Duan Y, Rani S, Newberg JT, Teplyakov AV. 2018. Investigation of the influence of oxygen plasma on supported silver nanoparticles. Journal of vacuum science \& technology. A, Vacuum, surfaces, and films : an official journal of the American Vacuum Society 36:01B101

168. Chen J, Zhao X, Grinblat G, Chen Z, Tan SJR, et al. 2018. Homoepitaxial Growth of Large-Scale Highly Organized Transition Metal Dichalcogenide Patterns. Advanced materials 30

169. Chen L, Han J, Ito Y, Fujita T, Huang G, et al. 2018. Heavily Doped and Highly Conductive Hierarchical Nanoporous Graphene for Electrochemical Hydrogen Production. Angewandte Chemie

170. Chen M, Li Z, Li W, Shan C, Li W, et al. 2018. Large-scale synthesis of single-crystalline self-standing SnSe2 nanoplate arrays for wearable gas sensors. Nanotechnology 29:455501

171. Kwak J, Kim SY, Jo Y, Kim NY, Kim SY, et al. 2018. Unraveling the Water Impermeability Discrepancy in CVD-Grown Graphene. Advanced materials 30:e1800022

172. Kumar R, Welle A, Becker F, Kopyeva I, Lahann J. 2018. Substrate-Independent Micropatterning of Polymer Brushes Based on Photolytic Deactivation of Chemical Vapor Deposition Based SurfaceInitiated Atom-Transfer Radical Polymerization Initiator Films. ACS applied materials \& interfaces

173. Kuk S, Nam HK, Wang Z, Hwang DJ. 2018. Effect of Laser Beam Dimension on Laser-Assisted Chemical Vapor Deposition of Silicon Nitride Thin Films. Journal of nanoscience and nanotechnology 18:7085-9

174. Ma T, Bai J, Wang Q, Li C. 2018. The novel synthesis of a continuous tube with laminated g-C3N4 nanosheets for enhancing photocatalytic activity and oxygen evolution reaction performance. Dalton transactions 47:10240-8

175. Ma X, Gao D. 2018. High Capacitive Storage Performance of Sulfur and Nitrogen Codoped Mesoporous Graphene. ChemSusChem 11:1048-55

176. Ma X, Kumar P, Mittal N, Khlyustova A, Daoutidis P, et al. 2018. Zeolitic imidazolate framework membranes made by ligand-induced permselectivation. Science 361:1008-11

177. Mawardi Anwar EM, Soleh Kosela, Widayanti Wibowo, Rahadian Zainul. 2015. Study of Pb(II) Biosorption from Aqueous Solution Using Immobilized Spirogyra Subsalsa Biomass. Journal of Chemical and Pharmaceutical Research

178. Desy Kurniawati IL, Salmariza Sy Harmiwati, Zulkarnain Chaidir, Edison Munaf, Rahmiana Zein, Hermansyah Aziz, Rahadian Zainul. 2015. Biosorption of Pb (II) from Aqueous Solutions Using Column Method by Lengkeng (Euphoria logan lour) Seed and Shell. Journal of Chemical and Pharmaceutical Research

179. Way AJ, Jacobberger RM, Arnold MS. 2018. Seed-Initiated Anisotropic Growth of Unidirectional Armchair Graphene Nanoribbon Arrays on Germanium. Nano letters 18:898-906

180. Wei J, Zhang Q, Zhao L, Nie Z, Hao L. 2018. Microwave Absorption Properties of Uniform Ultra-Long $\mathrm{SiC}$ Nanowires. Journal of nanoscience and nanotechnology 18:1224-31

181. Wen F, Tutuc E. 2018. Enhanced Electron Mobility in Nonplanar Tensile Strained Si Epitaxially Grown on SixGe1-x Nanowires. Nano letters 18:94-100 
182. Braun E, Lee Y, Moosavi SM, Barthel S, Mercado R, et al. 2018. Generating carbon schwarzites via zeolite-templating. Proceedings of the National Academy of Sciences of the United States of America 115:E8116-E24

183. Chang RJ, Tan H, Wang X, Porter B, Chen T, et al. 2018. High-Performance All 2D-Layered Tin Disulfide: Graphene Photodetecting Transistors with Thickness-Controlled Interface Dynamics. ACS applied materials \& interfaces 10:13002-10

184. Chee SW, Kammler M, Graham J, Gignac L, Reuter MC, et al. 2018. Directed Self-Assembly of Ge Quantum Dots Using Focused Si(2+) Ion Beam Patterning. Scientific reports 8:9361

185. Chen CC, Wang FH, Chang SC, Yang CF. 2018. Using Oxygen Plasma Pretreatment to Enhance the Properties of F-Doped ZnO Films Prepared on Polyimide Substrates. Materials 11

186. E S, Wu L, Li C, Zhu Z, Long X, et al. 2018. Growth of boron nitride nanotubes from magnesium diboride catalysts. Nanoscale 10:13895-901

187. Aneni EC, Osondu CU, De La Cruz J, Martin SS, Blaha MJ, et al. 2018. Lipoprotein Sub-Fractions by Ion-Mobility Analysis and Its Association with Subclinical Coronary Atherosclerosis in High-Risk Individuals. Journal of atherosclerosis and thrombosis

188. Apte A, Kochat V, Rajak P, Krishnamoorthy A, Manimunda P, et al. 2018. Structural Phase Transformation in Strained Monolayer MoWSe2 Alloy. ACS nano 12:3468-76

189. M., Yani, S. R., \& Zainul, R. (2017, September 4). Aktivasi Tanah Napa dan Pengaruhnya Terhadap Adsorpsi Ion Timbal (II)/ Pb2+. https://doi.org/10.31227/osf.io/ps523

190. Zainul, R., Oktavia, B., Dewata, I., \& efendi, j. (2017, February 4). Studi Dinamika Molekular dan Kinetika Reaksi pada Pembelahan Molekul Air untuk Produksi Gas Hidrogen. https://doi.org/10.31227/osf.io/876s3

191. Zainul, R., \& Dewata, I. (2015, December 29). Determination of pH-BOD-COD and degradation in batang arau watersheds at Padang city. https://doi.org/10.31227/osf.io/efdzj

192. H., Sanjaya, H., \& Zainul, R. (2016, August 30). Synthesis and Electrical Properties of ZnO-ITO and AlITO thin Film by Spin Coating Technique Through Sol Gel Process. https://doi.org/10.31227/osf.io/unrt4

193. Zainul, R. (2016, September 24). Determination of the half-life and the quantum yield of $\mathrm{ZnO}$ semiconductor photocatalyst in humic acid. https://doi.org/10.31227/osf.io/e8a9x

194. Zainul, R. (2016, December 18). Design and Modification of Copper Oxide Electrodes for Improving Conversion Coefficient Indoors Lights (PV-Cell) Photocells. https://doi.org/10.31227/osf.io/pgn84

195. Zainul, R., Alif, A., Aziz, H., Arief, S., \& s. (2015, October 22). Photoelectrosplitting Water Mechanism at Carbon Electrode Surface using Indoor lights. https://doi.org/10.31227/osf.io/vcxq8

196. H., Sanjaya, H., \& Zainul, R. (2016, August 30). Synthesis and Electrical Properties of ZnO-ITO and AlITO thin Film by Spin Coating Technique Through Sol Gel Process. https://doi.org/10.31227/osf.io/unrt4

197. Anhar, A., Sumarmin, R., \& Zainul, R. (2016, August 30). Measurement of Glycemic Index of West Sumatera Local Rice Genotypes for Healthy Food Selection. https://doi.org/10.31227/osf.io/tgy8h

198. M., Sanjaya, H., \& Zainul, R. (2015, December 30). Characterization of napa soil and adsorption of Pb (II) from aqueous solutions using on column method. https://doi.org/10.31227/osf.io/t8fh9

199. chaidir, z., Fadjria, N., A., \& Zainul, R. (2016, December 5). ISOLATION AND MOLECULAR IDENTIFICATION OF FRESHWATER MICROALGAE IN MANINJAU LAKE WEST SUMATERA. https://doi.org/10.31227/osf.io/nbcuf

200. chaidir, z., Zainul, R., Nurakhbari, D., \& Salim, M. (2016, September 24). Optimization of Spirulina Platensis Culture for Antioxidant Production. https://doi.org/10.17605/OSF.IO/FD6E4 


\title{
LPD ( Liquid Phasa Deposition ) : Prinsip dan Metode
}

\author{
Rentia Lestari*1 ${ }^{1}$, Pepi Mardianasari*² ${ }^{2}$ dan Rahadian Zainul $*^{3}$ \\ ${ }^{1}$ Chemistry Education, FMIPA, Universitas Negeri Padang, Indonesia \\ ${ }^{2}$ Chemistry Education, FMIPA, Universitas Negeri Padang, Indonesia \\ ${ }^{3}$ Physical Chemistry Laboratory, FMIPA,Universitas Negeri Padang, Indonesia
}

\begin{abstract}
*E-mail rentialestari8597@gmail.com, pepimardianasari28@gmail.com, rahadianzmsiphd@yahoo.com
\end{abstract}

\begin{abstract}
Abstrak : Deposisi fasa cair (LPD) merupakan suatu metode yang digunakan untuk memproduksi film oksida pada suhu rendah dengan skala nanometer. Dalam metode ini, film oksida yang diproduksi akan bertindak sebagai interlayer dielektrik, gerbang oksida dalam transistor dan dalam fabrikasi sirkuit terpadu dalam teknologi ULI ( ultralarge-scale integration ) Dan film oksida ini juga berperan penting dalam perangkat semikonduktor sebagai isolator listrik. Review ini bertujuan untuk mengetahui dan teknik metode liquid phasa deposition (LPD) yang berbasis oksida logam. Metode LPD ini juga dapat digunakan dalam memproduksi keramik polikristalin pada suhu rendah dan salah film oksida yang diproduksi yaitu berupa film silikon dioksida $\left(\mathrm{SiO}_{2}\right)$.
\end{abstract}

Keyword : liquid phasa deposition (LPD), film oksida, review

\section{Pendahuluan}

Perkembangan aplikasi nanoteknologi pada material berukuran kecil atau nanopartikel telah menjadi sorotan saat ini, karena nanopartikel memiliki sifat katalis yang baik. Dan adapun nanopartikel itu sendiri dapat terbentuk dari campuran satu logam atau mono dan dapat juga terbentuk dari campuran dua atau lebih logam yang biasa disebut juga dengan alloy. Alloy merupakan campuran dari dua atau lebih jenis logam. Metode deposisi fasa cair merupakan metode yang sangat sederhana dan tidak memerlukan peralatan khusus seperti sistem vakum pada metode fasa gas. Hal ini karena mudah diterapkan ke berbagai jenis substrat dengan luas permukaan yang besar dan morfologi permukaan yang kompleks pada suhu rendah. Metode deposisi fasa cair[18] ini digunakan untuk nonelektrokimia dalam memproduksi film keramik polikristalin pada suhu rendah, dan film yang diproduksi berupa film silikon dioksida $\left(\mathrm{SiO}_{2}\right)$. Banyak metode yang dapat digunakan untuk memproduksi film silikon dioksida seperti oksidasi termal, deposisi uap kimia (CVD), dan sputtering [35,36,37]. Namun metode-metode ini memiliki beberapa kelemahan seperti kebutuhan peralatan khusus seperti vakum serta prekusor organologam yang mahal[11].

Dan dari kelemahan metode-metode yang telah digunakan sebelumnya, maka digunakanlah metode liquid phasa deposition (LPD) yang berguna untuk mengendapkan film oksida pada suhu rendah dalam larutan berair. Dan metode LPD ini juga dapat mengatasi kekurangan dari metodemetode yang telah digunakan sebelumnya karena tidak membutuhkan peralatan khusus seperti vakum dan prekusor organologam serta pereaksi sensitif. Adapun keunggulan dari metode LPD ini yaitu biaya produksi yang rendah, berkembang dengan mudah pada suhu kamar dan yang paling terpenting yaitu memiliki dampak pada lingkungan yang kecil. Dan metode LPD ini juga sangat berguna dalam melapisi

substrat yang nonpolar[11]. 
Pada tahun 1998, Nagayama dkk menyatakan bahwa film $\mathrm{SiO}_{2}$ dapat disimpan pada kaca dalam larutan $\mathrm{H}_{2} \mathrm{SiF}_{6}$ yang jenuh dengan silika, setelah $\mathrm{H}_{3} \mathrm{BO}_{3}$ ditambahkan ke dalam larutan $\mathrm{H}_{2} \mathrm{SiF}_{6}$ yang jenuh dengan $\mathrm{SiO}_{2}[12]$. Whitsitt dan Barron menemukan bahwa film $\mathrm{SiO}_{2}$ dapat dibentuk pada substrat dalam larutan $\mathrm{H}_{2} \mathrm{SiF}_{6}$ yang jenuh dengan $\mathrm{SiO}_{2}$ dengan melarutkan aluminium bukan $\mathrm{H}_{3} \mathrm{BO}_{3}[11]$. Kemudian, Tsukuma et al, meneliti asam silikat lainnya yang memiliki kemampuan menyimpan film pada substrat dan menjelaskan pengolahan dan sifat dari film silika dengan beberapa kelompok organik, yang disimpan dalam fasa cair[13]. Asam borat atau logam aluminium dapat digunakan untuk menghasilkan lebib banyak silikon dioksida, namun penggunaan aditif tambahan ini dapat mempengaruhi sifat film karena bahan lain mungkin didoping ke dalam $\mathrm{SiO}_{2}$ dan meningkatkan tingkat pengotor. Akibatnya kualitas dan sifat isolasi $\mathrm{SiO}_{2}$ terdegradasi.

Dan metode liquid phase deposition ini juga dapat digunakan dalam pembuatan susunan skala nanometer pada nanopartikel Titanium dioksida $\left(\mathrm{TiO}_{2}\right)$ yang direaksikan dengan ruthenium $(\mathrm{Ru})$. Film-film yang diproduksi ini akan bertindak sebagai interlayer dielektrik, gerbang oksida dalam transistor dan dalam fabrikasi sirkuit terpadu dalam teknologi ultralarge-scale integration (ULI). Selain itu, film oksida berperan penting dalam perangkat semikonduktor sebagai isolator listrik dan juga merupakan salah satu komponen pelapis antirefleksi optik dalam metode liquid crystal display (LCD).

Titanium dioksida $\left(\mathrm{TiO}_{2}\right)$ merupakan semikonduktor yang bersifat inert dan stabil terhadap korosi oleh bahan kimia[27]. Berdasarkan fase kristalnya[19] $\mathrm{TiO}_{2}$ memiliki 3 fase, yaitu anatase, brookite, dan rutile. Dan fasa yang dimanfaatkan adalah fasa anastase. Keunggulan dari fasa anastase adalah memiliki struktur nanopori berukuran nanometer. Nanopartikel yang memiliki struktur morfologi dalam skala nanometer yang berguna untuk keperluan industri, pertanian dan sebagainya. Karena struktur nanopori mempunyai struktur luas permukaan yang tinggi sehingga akan menaikkan jumlah dye yang terserap dan implikasinya akan menaikkan jumlah cahaya yang terserap. Komposisi $\mathrm{TiO}_{2}$ dapat berubah dengan cara di doping, dan proses pendopingan ini material yang digunakan yaitu unsur logam. Dimana kehadiran ion unsur logam akan mempengaruhi difat dari titanium dioksida yang reaktif terhadap cahaya dan dapat juga menghambat proses rekombinasi elektron-hole (eksiton) pada permukaan $\mathrm{TiO}_{2}[5]$. Selain itu proses pendopingan juga dapat meningkatkan nilai konduktivitas dari bahan semikonduktor yang hanya membawa satu muatan elaktron (hole) saja[15]. Adapun salah satu logam yang dapat digunakan untuk pendopingan titanium dioksida yaitu ruthenium. Ruthenium merupakan suatu unsur logam yang baik sekali sebagai katalis[4].

\section{Metode}

Beberapa proses yang digunakan dalam liquid phase deposition dapat dilihat pada skema yang diuraikan di bawah ini. 


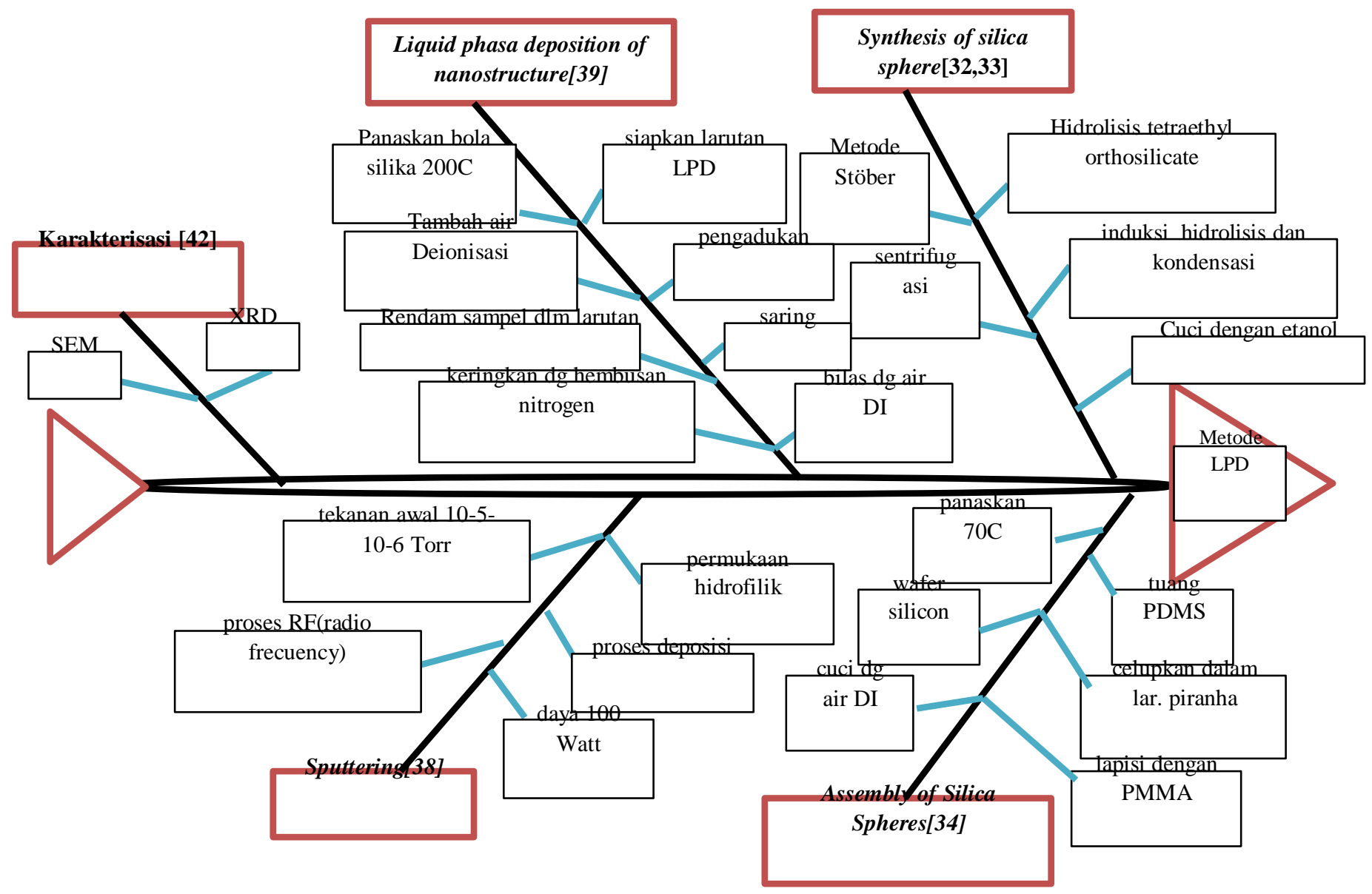

Bagan 1. Fishbone dalam produksi $\mathrm{SiO}_{2}$

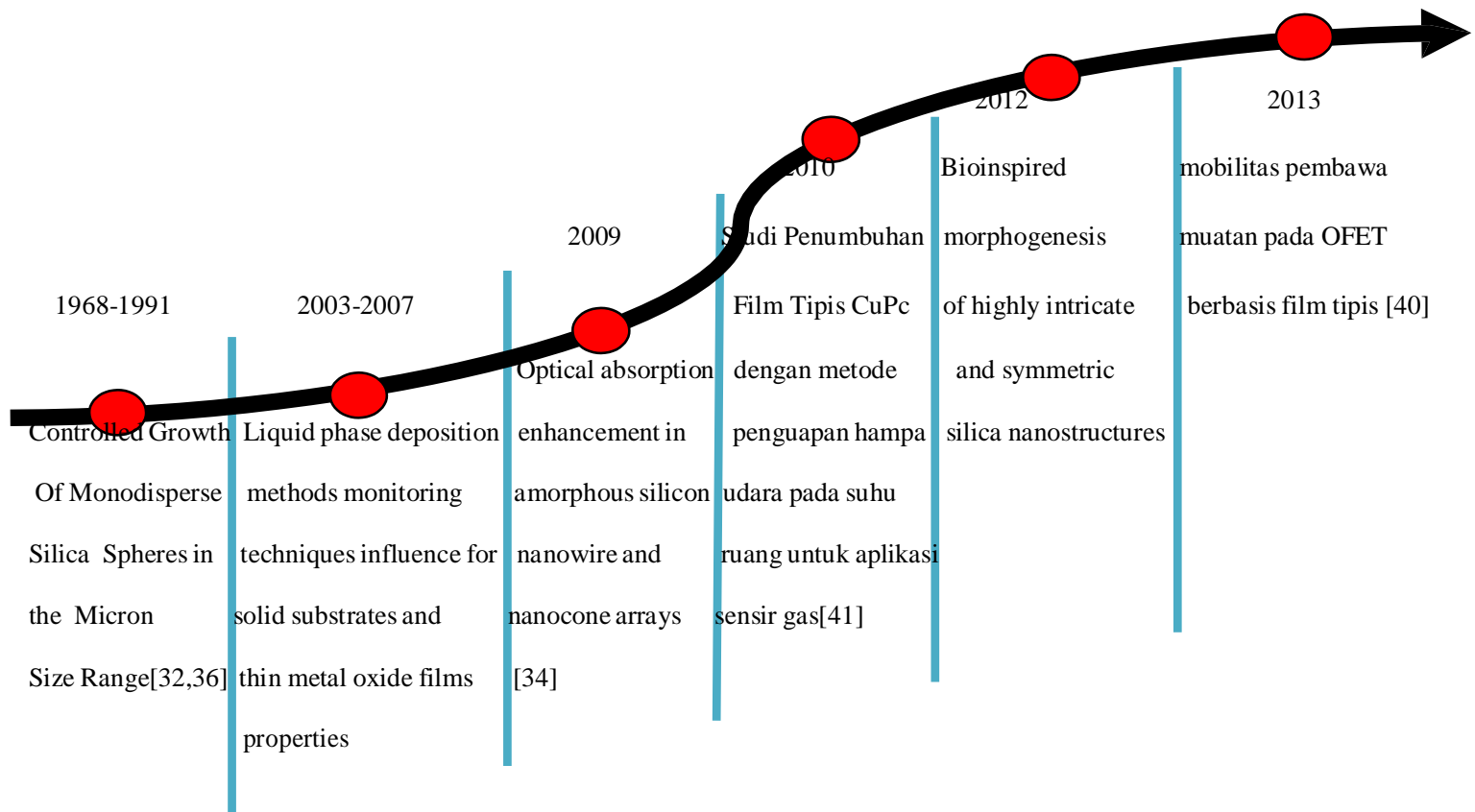

Bagan 2. Road Maps Liquid Phasa Deposition 
Keterangan:

1968 Controlled Growth of Monodisperse Silica Spheres in the Micron Size Range

1991 Formation of silicon dioxide films in acidic solutions

2003 Synthesis of colloidal crystals of controllable thickness through the Langmuir-Blodgett technique

2005 Smart control of monodisperse stöber silica particles: effect of reactant addition rate on growth process

2007 Silicon dioxide deposited by using liquid phase deposition at room temperature for nanometer-scaled isolation technology

2007 Liquid phase deposition methods monitoring techniques influence for solid substrates and thin metal oxide films properties

2009 Facile organization of colloidal particles into large, perfect one-and two-dimensional arrays by dry manual assembly on patterned substrates

2010 Studi Penumbuhan Film Tipis CuPc dengan metode Penguapan Hampa Udara pada Suhu Ruang Untuk Aplikasi Sensir Gas

2012 Bioinspired morphogenesis of highly intricate and symmetric silica nanostructures

2013 Mobilitas Pembawa Muatan pada OFET ( Organic Field Effect Transistor ) Berbasis Film Tipis

\section{Pembahasan}

Deposisi fasa cair (LPD)[1-24] merupakan suatu metode yang berguna untuk memproduksi film oksida pada suhu rendah dengan skala nanometer. Metode deposisi fasa cair ini digunakan untuk menyeragamkan permukaan dan untuk menurunkan suhu selama proses pengendapan berlangsung. Metode sintesis film tipis yang banyak digunakan adalah proses elektrodeposisi[22]. Proses elektrodeposisi terjadi karena adanya arus listrik yang mengalir dan mengakibatkan mengurainya elektron-elektron dalam larutan[23]. Sintesis film tipis dapat juga dilakukan dengan teknik galvanostatik dengan sistem tiga elektroda. Metode galvanostatik[26] merupakan salah satu metode elektropolimerisasi dimana proses doping terjadi secara bersamaan dengan polimerisasi. Metode galvanostatik ini menggunkan rangkaian alat elektropolimerisasi galvanostatik yang terdiri dari sumber arus, tegangan, elektroda karbon sebagai elektroda kerja dan nikel sebgai elektroda mitra.

Dalam sintesis deposisi faca cair menggunakan teknik galvanostatik dengan sistem tiga elektroda yaitu elektroda kerja, elektroda kounter,dan elektroda pembanding. Elektroda kerja berperan sebagai substrat atau tempat melekatnya deposisi paduan logam. Pada elektroda kerja terjadi proses reduksi dan pada elektroda kounter terjadi proses oksidasi. LPD ini dilakukan pada silika monolayer semi tertutup yang tetutup rapat oleh bola silika. Dan larutan LPD ini dibuat dari asam hidroflourosilikat tak jenuh dengan bubuk silika. Kemudian dari larutan tersebut akan dihasilkan silikon dioksida.

Untuk mensintesis bola silika dengan berbagai ukuran dapat dilakukan dengan mengukur konsentrasi dari reaktan yang digunakan. Dan distribusai ukuran ini merupakan faktor penting untuk membentuk struktur nano yang seragam yang terdiri dari bola silika dengan kepadatan yang rendah cacat menggunakan substrat berpola. Kemudian menggosokkan bola silika dengan stempel plant 
design management system (PDMS), dan setelah itu monolayer dari bola silika dipindahkan ke lempengan silikon dengan lapisan $\mathrm{SiO}_{2}$ dengan tebal $300 \mathrm{~nm}$ dan poly methyl methacrylate (PMMA). Dan adapun salah satu keuntungan dari metode ini adalah manfaat dari bubuk bola silika daripada larutan dispersi bola silika. Metode yang digunakan metode perakitan Langmuir-Blodgett, dimana larutan dispersi dilusi dari bola silika yang dapat menyebar sepanjang antarmuka antara udara dan air[28,29]. Kemudian bola silika mengering dengan cara menguap dari bola silika tersebut. Dan penguapan ini dapat mempengaruhi perakitan bola silika, karena daapt retak akibat penyusutan partikel, tetapi pada akhirnya akan tebentuk butiran. Meskipun metode ini dapat menyebabkan retak pada pembentukkan, namun ketika bubuk silika digosok pada substrat wafer Si bermotif, perakitan akan sempurna berbentuk segi enam dan teretuk di atas area yang sangat besar.

Dalam deposisi fasa cair ini, metode yang banyak digunakan adalah metode elektrodeposisi. Karena elektrodeposisi memilki banyak keuntungan seperti proses yang cepat, kemurnian yang tinggi, dan dapat diaplikasikan dalam skala industri, dapat melakukan kontrol komposisi paduan logam, konsumsi energi yang rendah, prefarasi film yang dapat dilakukan dalam satu tahap dan proses elektrodeposisi dapat dilakukan pada area yang luas. Kemudian pada proses elektrodeposisi terdapat beberapa parameter yang dioptimasi sehingga dapat menghasilkan film tipis susai dengan yang diinginkan. Adapun parameter yang dimaksud adalah rapat arus, ketebalan film, pH elektrolit, suhu deposisi, potensial deposisi, dan komposisi elektrolit. Pada proses elektrodeposisi dapat dilakukan dengan dua teknik yaitu mengontrol potensial ( potensiostatik) dan arus ( galvanostatik ) dalam rangkaian sel elektrodeposisi selama proses berlangsung.

\section{Tahapan proses liquid phase deposition}

\section{Synthesis silica sphere}

Pada metode sintesis silika sphere ini, bola silika disintesis dengan menggunakan metode Stöber yang melibatkan sintesis tetraethyl ortosilicate (TEOS) dalam etanol $\left(\mathrm{C}_{2} \mathrm{H}_{5} \mathrm{OH}\right)$ dan dengan adanya amonia $\left(\mathrm{NH}_{3}\right)$ sebagai katalis[30,31]. Dengan mengendalikan konsentrasi reaktan, ukuran bola silika akan berubah, kemudian menambahkan TEOS dan mengaduknya untuk menginduksi proses hidrolisis dan kondensasi. Sehingga suspensi silika yang dihasilkan disentrifugasi dan dicuci dengan redispersi berulang dalam etanol murni beberapa kali.

Metode Stöber adalah metode yang digunakan untuk menyiapkan partikel silika yang dapat dikontrol dan seragam ukurannya untuk aplikasi dalam ilmu material. Metode Stöber merupakan metode kalsik pembuatan partikel silika dalam suasana basa[25].

\section{Assembly of Silica Spheres}

Pada metode ini, wafer silikon dengan lapisan $\mathrm{SiO}_{2}$ dilapisi dengan poly methyl methacrylate (PMMA) dengan lapisan spin. Substrat bermotif dari Si dicelupkan ke dalam larutan piranha selama 30 menit, kemudian dicuci dengan air yang sudah di deionisasi (DI). Larutan piranha adalah larutan yang juga dikenal sebagai piranha etch yang merupakan campuran antara asam sulfat dan hidrogen peroksida yang digunakan untuk membersihkan residu organik dari substrat[32].

\section{Liquid phasa deposition of nanostructure}

Seperti yang telah disebutkan pada bagian sebelumnya, bola silika Hexagonal closed packed (HCP) dipanaskan terlebih dahulu pada suhu 200C selama 2 menit untuk melunakkan PMMA, yang mana nantinya dapat menyatukan bola silika dengan lapisan poly methyl methacrylate (PMMA). 
Kemudian pada sisi yang lain, untuk membuat larutan deposisi pasa cair dapat dilakukan sebagai berikut : Hal pertama yang harus dilakukan yaitu mencampurkan asam hidroflourosilikat $\left(\mathrm{H}_{2} \mathrm{SiF}_{6}\right)$ dengan bubuk silika $\left(\mathrm{SiO}_{2}\right)$ yang harus diaduk terus selama semalaman pada kecepatan $400 \mathrm{rpm}$, setelah proses pengadukan selanjutnya larutan dari campuran antara asam hidroflourosilikat dan serbuk silika disaring menggunakan penyaring vakum, dan dilanjutkan dengan penambahan air deionisasi ke dalam larutan dengan perbandingan 1:2 yang nantinya untuk memungkinkan supersaturasi dengan silikat. Kemudian setelah menyiapkan larutan, sampel yang akan digunakan untuk penelitian ini direndam dalam larutan yang telah dibuat selama 5 menit sampai 30 menit. Dan setelah bereaksi, sampel yang telah direndam dibilas kembali dengan air deionisasi serta dikeringkan dengan hembusan nitrogen.

\section{Sputtering}

Sputtering [43-48]adalah proses terlemparnya (ejected) materi dari suatu permukaan zat padat atau zat cair akibat tumbukan partikel berenergi tinggi sehingga terjadi pertukaran momentum (momentum exchange). Jenis partikel yang ditembakkan berasal dari ion gas yang tidak mudah bereaksi oleh zat lain atau gas inert. Materi yang terlempar berupa atom dari suatu logam atau campuran logam yang akan menempel pada permukaan substrat.

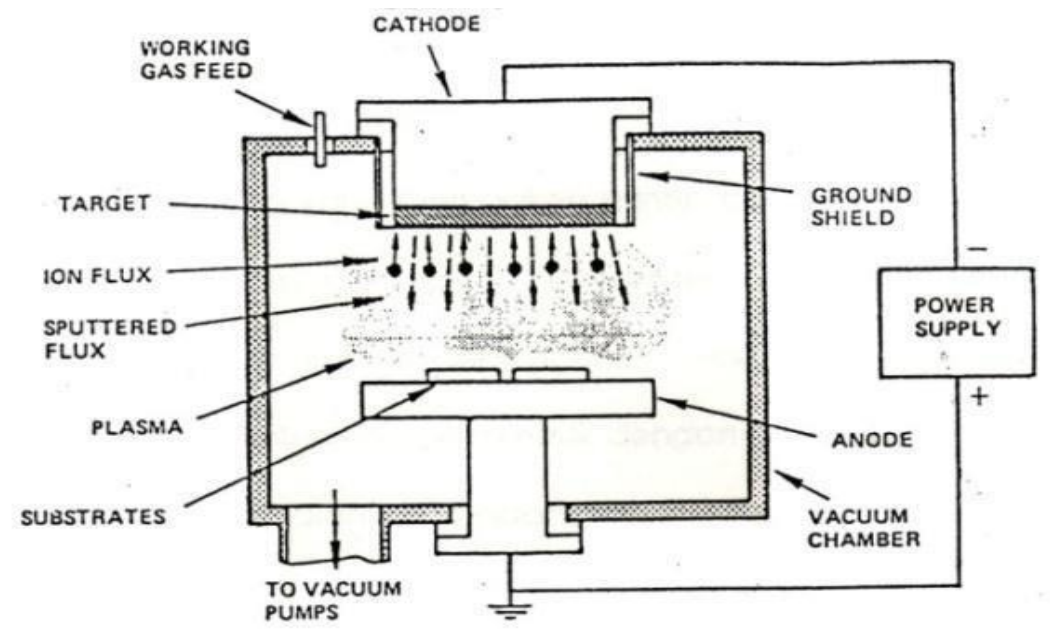

Gambar 1. Sistem Sputtering Diode Planar dengan Glow Discharge(Sumber: Gary E. McGuire, 1980:365)

\subsection{Prinsip dasar Sputtering}

Dua kejadian yang merupakan prinsip dasar sputtering yaitu:

1. Terlemparnya atom-atom dari permukaan target akibat adanya perpindahan energi oleh ion-ion penumbukan berenergi tinggi. Terjadinya pertukaran momentum antara ion penumbuk dengan atom-atom target pada sputtering merupakan kejadian yang dapat menjelaskan proses terlemparnya atom-atom tersebut.

2. Dalam tabung akan terlihat suatu kilapan cahaya (glow discharge) yang merupakan terjadinya plasma secara kontinyu. Hal ini menunjukkan proses pendeposisian/pelapisan sedang berlangsung dalam tabung tersebut.

\subsection{Kecepaatn pendeposisian sputtering}

Dalam sistem sputtering, kecepatan pendeposisian (rate deposition of sputtering) adalah ketebalan lapisan per satuan waktu. Dan untuk mengetahui kecepatan pendeposisian 
sputtering hanya dapat diketahui berdasarkan hasil pengukuran percobaan secara fisik yaitu dengan mengukur ketebalan film yang terbentuk.

Kecepatan sputtering didefinisikan sebagai jumlah atom uang terpetal per satuan waktu dan luas.

\subsection{Tahapan proses}

Membersihkan substrat

Tahapan pembersihan substrat ini sangat penting karena akan menentukan kualitas dari lapisan tipis yang terbentuk. Pengotor yang terdapat pada substrat akan dilarutkan dengan menggunakan bahan-bahan kimia. Agar proses pembersihan lebih sempurna. Dan bahan yang digunakan dalam proses pembersihan ini adalah trichlouro etylen (TCE), trichlouro ethan, etnol atau aceton.

\section{Proses sputtering}

Proses sputtering dilakukan pada mode RF ( radio frecuency) pada tekanan awal (based pressure) berkisar antara $10^{-5}-10^{-6}$ Torr. Setelah tercapai kondisi tersebut, selanjutnya masukkan gas argon sampai tercapai tekanan konstan 4 mTorr. Dan daya yang diberikan yaitu 100 watt. Dan sebelum dilakukannya proses deposisi, terlebih dahulu dilakukan proses etsa dari substrat yang akan dilapisi dengan cara membalik arah ion penumbuk menuju substrat dengan energi rendah, sehingga hanya untuk membersihkan partikel-partikel pengotor tanpa merusak permukaan substrat. Dan juga cara ini dapat menaikkan daya adhesif dari film pada permukaan substrat. Kemudian proses deposisi dilakukan menggunakan target yang diinginkan. Adapun alat sputtering yang digunakan dapat dipasang 3 macam target yang dapat digunakan secara bergantian.

Metode pengukuran dan pengujian

Alat sputtering yang digunakna yaitu alat yang sudah dilengkapi dengan monitor pengukur ketebalan. Adapun prinsip kerja dari alat ini adalah adanya kristal osilator yang frekuensi getarnya akan berubah sesuai dengan ketebalan film yang dihasilkan. Semakin banyak hasil proses deposisi yang menempel pada kristal, getaran osilator kristal akan semakin rendah. Perbedaan frekuensi ini dikonversi sebagai perbedaan ketebalan, yang akan langsung tampil pada layar monitor. Adapun alat sputtering dapat dilihat pada gambar di bawah ini:

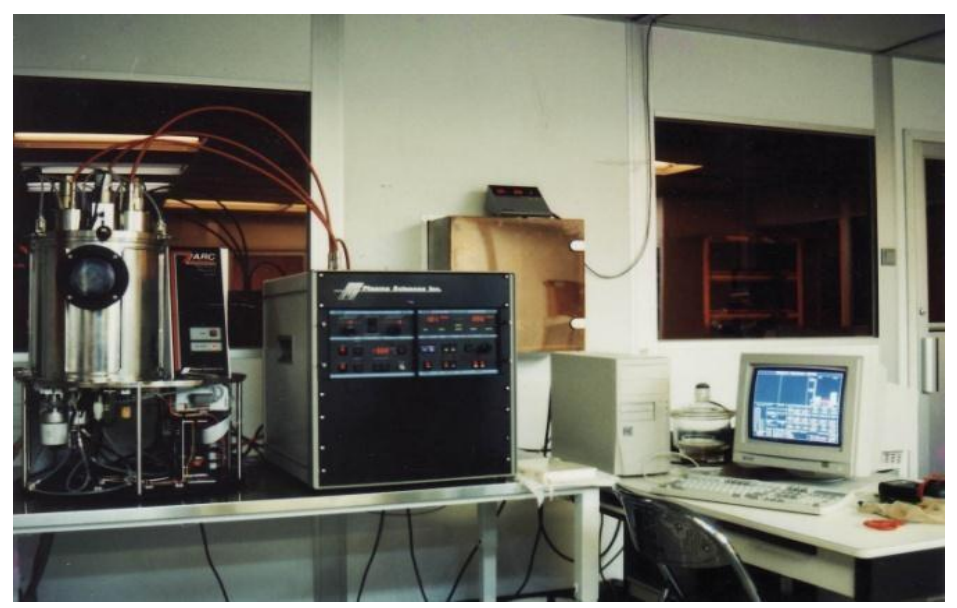

Peralatan Sistem Sputtering ARC-12M 


\section{Karakterisasi}

1. X-ray

Sinar X pertama kali ditemukan oleh Wilhelm Conrad Rontgen pada tahun 1895. Karena asalnya tidak diketahui pada waktu itu makanya disebut dengan sinar X. Sinar x digunakan dengan tujuan pemeriksaan agar tidak merusak material. Sinar $X$ juga dapat digunakan dalam menghasilkan pola difraksi tertentu yang dapat digunakan dalam analisis kualitatif dan kuantitatif material. X-ray marupakan salah analisis non destruktif yang penting untuk menganalisis semua jenis materi seperti serbuk, cairan dan kristal.

Spektoskopi sinar X-ray merupakan salah satu metode karakterisasi material yang paling tua dan paling sering digunakna hingga sekarang. Teknik ini digunakan untuk mengidentifikasi fasa kristalin dalam material dengan cara menentukan parameter struktur krisi serta mendapatkan ukuran partikel.ilkan dari penembakan logam yang berenergi tinggi.

Sinar $\mathrm{X}$ adalah gelombang elektromagnetik dengan panjang gelombang $(0,5-2,0)$ mikron. Metode difraksi sinar X digunakan untuk mengaetahui lapisan tipis ( film tipis ) yang terbentuk. Keuntungan menggunakan difraksi sinar $\mathrm{X}$ adalah karena kemampuan penetrasinya, sebab sinar $\mathrm{x}$ memiliki energi yang sangat tinggi akibat panjang gelombangnya yang pendek.

\section{SEM ( Scanning Electron Microscope)}

SEM merupakan jenis instrumen mikroskop elektron yang menggunakn berkas elektron untuk menggambarkan bentuk permukaan material yang dianalisis. Fungsi SEM adalah memindai yang terfokus pada balok halus elektron ke sampel. Elektron berinteraksi pada sampel komposisi molekul. Energi lektron menuju sampel secara langsung dalam proporsi jenis interaksi elektron yang dihasilkan sampel. Karakterisasi bahan menggunkan SEM dimanfaatkan untuk melihat struktur topografi permukaan, ukuran butiran, cacat struktural, dan komposisi pencemaran suatu bahan. Mikroskop ini digunakan untuk mempelajari bentuk dari permukaan objek, yang diperbesar antara 1.000- 4.000 kali. Prinsip kerja SEM yaitu sumber elktron dari filamen yang terbuat dari tungsten memancarkan berkas elektron. Jika elektron tersebut berinteraksi dengan bahan maka akan menghasilkan elektron sekunder dan sinar-X karakterisasi. SEM memiliki resolusi yang lebih tinggi daripada mikroskop optik. Hal ini disebabkan oleh panjang gelombang de Broglie yang memiliki elektron lebih pedek daripada gelombang optik. Karena semakin kecil gelombang digunakan maka resluosi yang dihasilkan mikroskop semakin tinggi.

\section{Kesimpulan}

Deposisi fasa cair merupakan suatu metode yang berguna untuk memproduksi film oksida pada suhu rendah dalam skala nanometer. Metode Liquid Phase Deposition (LPD) ini juga dapat digunakan dalam memproduksi keramik polikristalin pada suhu rendah dan salah film oksida yang diproduksi yaitu berupa film silikon dioksida $\left(\mathrm{SiO}_{2}\right)$. Selain $\mathrm{SiO}_{2}$ metode LPD ini juga dapat digunakan untuk membuat susunan skala nanometer pada Titanium Dioksida $\left(\mathrm{TiO}_{2}\right)$ yang direaksikan dengan ruthenium ( $\mathrm{Ru}$ ). Dalam memproduksi film $\mathrm{SiO}_{2}$ ini banyak metode yang bisa digunakan seperti oksidasi termal, deposisi uap kimia dan sputtering. Namun metode-metode tersebut memiliki beberapa kelemahan seperti kebutuhan peralatan khusus seperti vakum serta prekusor organologam yang mahal. Dari kelemahan metode-metode tersebut, maka digunakanlah metode liquid phase deposistion. Karena metode ini dapat mengatasi kelemahan dari metode sebelumnya. Adapun keunggulan dari metode liquid phase deposition ini yaitu biaya produksi yang rendah, mudah berkembang dalam sugu kamar, dan yang paling penting yaitu memiliki dampak pada lingkungan yang

kecil. 


\section{Referensi}

[1] S.J. An, Y.H. Kim, C. Lee, D.Y. Park, M.S. Jeong, Scientific reports 8 (2018) 12957.

[2] H. Bao, H. Zhang, L. Zhou, H. Fu, G. Liu, Y. Li, W. Cai, ACS applied materials \& interfaces 10 (2018) 19027.

[3] A.J. Carlson, P. Bard, W.E. Garrey, F.W. Weymouth, M.B. Visscher, Science 100 (1944) 518

[4] J.H. Chen, Y.L. Zhong, L.J. Li, C.D. Chen, Nanotechnology 29 (2018) 225707.

[5] X. Chen, S.S. Mao, Chemical reviews 107 (2007) 2891.

[6] N. Cheng, T.L. Andrew, Journal of visualized experiments : JoVE (2018).

[7] L. Fortunato, Y. Jang, J.G. Lee, S. Jeong, S. Lee, T. Leiknes, N. Ghaffour, Water research $132(2018) 34$.

[8] C. Guliy capital O, B.D. Zaitsev, I.A. Borodina, C.E.M.C. Shikhabudinov capital A, A.A. Teplykh, S.A. Staroverov, A.S. Fomin, Talanta 178 (2018) 569.

[9] I. Gurrappa, L. Binder, Science and technology of advanced materials 9 (2008) 043001.

[10] E. Lallemand, C. Arvieux, G. Coiffier, J.L. Polard, J.D. Albert, P. Guggenbuhl, A. JolivetGougeon, Research in microbiology 168 (2017) 122.

[11] H. Liu, X. Cao, G. Liu, Y. Wang, N. Zhang, T. Li, R. Tough, Chemosphere 93 (2013) 160.

[12] L. Liu, Z. Liu, A. Liu, X. Gu, C. Ge, F. Gao, L. Dong, ChemSusChem 7 (2014) 618.

[13] A.R. Martin, W.H. Finlay, Journal of aerosol medicine and pulmonary drug delivery 31 (2018) 49.

[14] A.K. Nguyen, R.J. Narayan, Annals of biomedical engineering 45 (2017) 84.

[15] B. Roose, S. Pathak, U. Steiner, Chemical Society reviews 44 (2015) 8326.

[16] D. Smith, Y. Kapoor, A. Hermans, R. Nofsinger, F. Kesisoglou, T. Gustafson, A. Procopio, International journal of pharmaceutics (2018).

[17] S. Sultana, S. Talegaonkar, D.K. Nishad, G. Mittal, F.J. Ahmad, A. Bhatnagar, European journal of pharmaceutics and biopharmaceutics : official journal of Arbeitsgemeinschaft fur Pharmazeutische Verfahrenstechnik e.V 126 (2018) 221.

[18] Y.T. Tsu, Y.W. Chen, Journal of nanoscience and nanotechnology 18 (2018) 301.

[19] A.A. Umar, I. Iwantono, A. Abdullah, M.M. Salleh, M. Oyama, Nanoscale research letters 7 (2012) 252.

[20] A.A. Umar, M.M. Salleh, B.Y. Majlis, M. Oyama, Journal of nanoscience and nanotechnology 11 (2011) 4974.

[21] M. Wilson, S.N. Barrientos-Palomo, P.C. Stevens, N.L. Mitchell, G. Oswald, C.M. Nagaraja, J.P.S. Badyal, ACS applied materials \& interfaces $10 \quad$ (2018) 4057. 
[22] D. Yang, J. Lee, D. Kim, I. Cho, J.G. Ok, I. Park, Langmuir : the ACS journal of surfaces and colloids 34 (2018) 4132.

[23] S.Y. Yoon, Y.S. Park, J.S. Lee, Langmuir : the ACS journal of surfaces and colloids 31 (2015) 249.

[24] X. Zhang, C. Sun, L. Zhang, H. Liu, B. Cao, L. Liu, W. Gong, Talanta 181 (2018) 352.

[25] Stöber, W., Fink, A, and Bohn, E. 1968. Controlled Growth of Monodisperse Silica Spheres in the Micron Size Range. Journal of Colloid and Interface Sciense. 26 62-69

[26] Kholik, Isa Abdul dkk. 2002. Optimasi Sintesis Polianilin secara Elektrokimia, Jurnal Penelitian, FMIPA-Universitas Jember.

[27] Kumara, M.S.W., dan Gontjang P. 2012. Studi Awal Fabrikasi Dye Sensitized Solar Cell (DSSC) dengan Menggunakan Ekstraksi Daun Bayam (Amaranthus Hybridus L.)Sebagai Dye Sensitizer dengan Variasi Jarak Sumber Cahaya pada DSSC, Jurnal ITS,Surabaya.

[28] S. Reculusa and S. Ravaine. 2003. Synthesis of colloidal crystals of controllable thickness through the Langmuir-Blodgett technique. Chemistry of Materials, vol. 15, no. 2, pp. 598605 .

[29] J. Zhu, Z. Yu, G. F. Burkhart et al. 2009. Optical absorption enhancement in amorphous silicon nanowire and nanocone arrays," Nano Letters, vol. 9, no. 1, pp. 279-282.

[30] W. Stöber, A. Fink, and E. Bohn. 1968. Controlled growth of monodisperse silica spheres in the micron size range," Journal of Colloid And Interface Science, vol. 26, no. 1, pp. 62-69.

[31] K. Nozawa, H. Gailhanou, L. Raison et al. 2005. Smart control of monodisperse stöber silica particles: effect of reactant addition rate on growth process. Langmuir, vol. 21, no. 4, pp. $1516-1523$.

[32] N. N. Khanh and B. Y. Kyung. 2009. Facile organization of colloidal particles into large, perfect one-and two-dimensional arrays by dry manual assembly on patterned substrates. Journal of the American Chemical Society, vol. 131, no. 40, pp. 14228-14230.

[33] K. S. Kim and Y. Roh. 2007. Silicon dioxide deposited by using liquid phase deposition at room temperature for nanometer-scaled isolation technology. Journal of the Korean Physical Society, vol. 51, no. 3, pp. 1191-1194.

[34] A. Hishinuma, T. Goda, M. Kitaoka, S. Hayashi, and H. Kawahara. 1991. Formation of silicon dioxide films in acidic solutions. Applied Surface Science, vol. 48-49, pp. 405-408.

[35] A. V. Valiulis and P. Silickas. 2007. Liquid phase deposition methods monitoring techniques influence for solid substrates and thin metal oxide films properties. Journal of Achievements in Materials and Manufacturing Engineering, vol. 24, pp. 188-192.

[36] Class, Walter and Murray. 1969. Solid state Technology: Sputtering Materials for Electronic Application. Edisi December 
[37] J. Yi, H. S. Jang, J. S. Lee, and W. I. Park. 2012. Bioinspired morphogenesis of highly intricate and symmetric silica nanostructures. Nano Letters, vol. 12, pp. 743-3748.

[38] Sujarwata dan Putut Marwoto. 2013. Mobilitas Pembawa Muatan pada OFET ( Organic Field Effect Transistor ) Berbasis Film Tipis. Jurnal MIPA, Vol 36, No. 2.

[39] Sujarwata dan Kuwat Triyana. 2010. Studi Penumbuhan Film Tipis CuPc dengan metode Penguapan Hampa Udara pada Suhu Ruang Untuk Aplikasi Sensir Gas. sainteknol ( Jurnal Sains dan Teknologi ) Vol 8. No. 2.

[40] Nur Aini Handayani. 2007. Analisis XRD pada Film Tipis $A l_{x} G a_{1-x} N$ di atas Si (111) yang Ditumbuhkan dengan Metode dc Magnetron Sputtering.

[41] Azizahwati. 2002. Studi Permukaan Film Tipis PbzRO, 525Ti, 47503 yang Ditumbuhkan dengan Metode DC Unbalanced Magnetron Sputtering. Jurnal Natur Indonesia 5 (1) : 50-56

[42] Eitssayeam S, Inthatha U, Pengpat K, Tunkasiri T. 2005. Properties Of CdS:Ni Films Prepared By Chemical Bath Deposition Methode. Journal Materials Science, 40, 3803-3807

[43] Maissel, Leon I dan Reinhard Glang. 1970. Handbook of Thin Film Technology . New York McGraw-Hill, Inc.

[44] Jones, Roydn D. 1982. Hybrid Circuit Design and Manufacture. New York, Marcel Dekker, Inc.

[45] Harper, Charles A \& Ronald M Sampson. 1984. Electronic Materials and Process Handbook, edisi ke II, Singapore, Mc Graw Hill Inc.

[46] Lee, Hong H. 1990. Fundamentals of solid state and electron device. Singapore, Me Graw hill Publishing company.

[47] Class, Walter and Murray. 1969. Solid state Technology: Sputtering Materials for Electronic Application. Edisi December

[48] Sequeda, F.O. 1986. Journal of Metal: Film deposition Techniques in Microelectronics. Edisi Februari, California.

[49] S. E. Babayan, J. Y. Jeong, A. Schütze et al. 2001. Deposition of silicon dioxide films with a non-equilibrium atmospheric-pressure plasma jet. Plasma Sources Science and Technology, vol. 10 , no. 4 , pp. $573-578$.

[50] M. F. Ceiler Jr., P. A. Kohl, and S. A. Bidstrup. 1995. Plasma-enhanced chemical vapor deposition of silicon dioxide deposited at low temperatures. Journal of the Electrochemical Society, vol. 142, no. 6, pp. 2067-2071.

[51] K. Ikeda, S. Nakayama, and M. Maeda. 1995. Characteristics of silicon dioxide films on patterned substrates prepared by atmospheric-pressure chemical vapor deposition using tetraethoxysilane and ozone. Journal of the Electrochemical Society, vol. 143, no. 5, pp. $1715-1718$. 
[52] K. Murase. 1994. Dielectric constant of silicon dioxide deposited by atmospheric-pressure chemical vapor deposition using tetraethylorthosilicate and ozone. Japanese Journal of Applied Physics, vol. 33, no. 3, pp. 1385-1389.

[53] S. K. Ray, C. K. Maiti, S. K. Lahiri, and N. B. Chakrabarti. 1994. TEOS-based PECVD of silicon dioxide for VLSI applications. Advanced Materials for Optics and Electronics, vol. 6, no. 2, pp. 73-82.

[54] K. S. Kim and Y. Roh. 2007. Silicon dioxide deposited by using liquid phase deposition at room temperature for nanometer-scaled isolation technology. Journal of the Korean Physical Society, vol. 51, no. 3, pp. 1191-1194.

[55] A. I. Kingon, J.-P. Maria, and S. K. Streiffer. 2000. Alternative dielectrics to silicon dioxide for memory and logic devices. Nature, vol. 406, no. 6799, pp. 1032-1038.

[56] A. Hishinuma, T. Goda, M. Kitaoka, S. Hayashi, and H. Kawahara. 1991. Formation of silicon dioxide films in acidic solutions. Applied Surface Science, vol. 48-49, pp. 405-408.

[57] A. V. Valiulis and P. Silickas. 2007. Liquid phase deposition methods monitoring techniques influence for solid substrates and thin metal oxide films properties. Journal of Achievements in Materials and Manufacturing Engineering, vol. 24, pp. 188-192.

[58] E. A. Whitsitt and A. R. Barron. 2004. Liquid phase deposition of silica: thin films, colloids and fullerenes [Ph.D. thesis].

[59] Yi, H. S. Jang, J. S. Lee, and W. I. Park. 2012. Bioinspired morphogenesis of highly intricate and symmetric silica nanostructures. Nano Letters, vol. 12, pp. 743-3748.

[60] C. J. Brinker and G. W. Scherer, Sol-Gel Science: the Physic and Chemistry of Sol-Gel Processing, Academic Press, San Diego

[61] Batzill, M., Morales, H.E., dan Diebold U. 2006. Influence of Nitrogen Doping on the Defect Formation and Surface Properties of TiO2 Rutile and Anatase. Physical Review Letters, 96: 31-34

[62] Begum, N.S., Ahmed, H.M.F., dan Gunashekar, K.R. 2008. Effects of Ni Doping on Photocatalytic Activity of TiO2 Thin Films Prepared by Liquid Phase Deposition Technique. Bull. Mater. Sci., 31(5): 747-751

[63] Burda, C., Yongbing, L., Chen, X., Samia, C.S.A., Stout, J., dan Gole, J.L. 2003. Enhanced Nitrogen Doping in TiO2 Nanoparticles, Nano Letters, 3(8): 1049-1051

[64] Carp, O., Huisman, C.L., dan Reller, A. 2004. Photoinduced Reactivity of Titanium Dioxide. Prog in Solid State Chem., 32

[65] Chen, X., dan Mao, S.S. 2007. Titanium dioxide nanomaterials: Synthesis, Properties, Modifications, and Applications. Chem Rev, 107

[66] Di Valentin, C., Gianfranco, P., dan Annabella, S. 2004. Origin of The Different Photoactivity of N-doped Anatase and Rutile TiO2. Phys. Rev. B., 70: 085116-085119 
[67] A.V.Valiulis, dkk. 2007. Liquid Phase Deposition Methods Monitoring Techniques Influence For Solid Substrates And Thin Metal Oxide Films Properties. Journal of Achievements in Materials and Manufacturing Engineering.

[68] Fengjiao Yu, dkk. 2013. Alloying and Dealloying of CuPt Bimetallic Nanocrystals. Materials International: Journal of Elsiever.

[69] JR, William D.Callister. 1980. Materials Science and Engineering An Introduction. United States of America: Von Hoffmann Press.

[70] Abdullah, Mikrajuddin, dkk. 2008. Sintesis Nanopartikel. Jurnal Nanosains dan Nanoteknologi.

[71] Albert, F.Cotton. dkk. 1990. Advance Inorganic Chemistry. Newyork: Interscience Publishers.

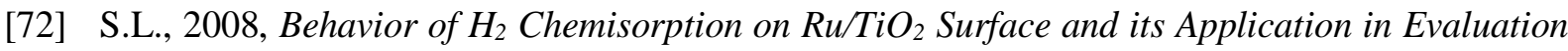
of Ru Particle Sizes Compared with TEM and XRD Analyses, Elsevier ScienceDirect.

[73] Timuda, G., E., Maddu, A., Irmansyah, Widiyatmoko, B., 2010, Sintesis Partikel Nanocrystalline TiO2 untuk Aplikasi Sel Surya Menggunakan Metode Sonokimia, Prosiding Pertemuan Ilmiah XXIV HFI Jateng \& DIY, hal. 104-109.

[74] Yuwono, A.H., Dhaneswara, D., Ferdiansyah, A., dan Rahman, A., 2011, Sel Surya Tersensitasi Pewarna Berbasis Nanopartikel TiO2 Hasil Proses Sol-Gel dan Perlakuan Pasca-Hidrotermal, Jurnal Material dan Energi Indonesia, Vol. 01, No.03, hal 127 140, Jurusan Fisika FMIPA Universitas Padjadjaran.

[75] Zhang, H. dan Banfield J.F., 2000, Understanding Polymorphic Phase Transformation Behavior during Growth of Nanocrystalline Aggregates: Insights from TiO2. J Phys Chem B, vol.104, pp. 3481.

[76] Zhang, Q. dan Cao, G., 2011, Nanostructured Photoelectrodes for Dye-Sensitized Solar Cells, ScienceDirect Nano Today (2011) 6, hal 91-109

[77] S. E. Babayan, J. Y. Jeong, A. Schütze et al. 2001. Deposition of silicon dioxide films with a non-equilibrium atmospheric-pressure plasma jet. Plasma Sources Science and Technology, vol. 10 , no. 4 , pp. 573-578.

[78] M. F. Ceiler Jr., P. A. Kohl, and S. A. Bidstrup. 1995. Plasma-enhanced chemical vapor deposition of silicon dioxide deposited at low temperatures. Journal of the Electrochemical Society, vol. 142, no. 6, pp. 2067-2071.

[79] Li, W., Wu, Q., Zhao, X., Huang, Z., Cao, J., Li, J., Liu, S. 2014. Enhanced thermal and mechanical properties of PVA composites formed with filamentous nanocellulose fibrils. Carbohydr. Polym. 113: 403-410. doi: 10.1016/j.carbpol.2014. 07.031.

[80] Reddy, J.P., Rhim, J.W. 2014. Characterization of bionanocomposite films prepared with agar and paper-mulberry pulp nanocellulose. Polym. 6(10): 2611-2624 doi:10.3390/polym6102611.

[81] Mattox, Donald M. 2010. Handbook of Physical Vapor Deposition (PVD) Processing. Elsivier. United States of America. 
[82] Senthilarasu, S. Y.B.Hahn. Soo-Hyoung Lee. 2008. Nano structure formation in vacuum evaporated zinc phthalocyanine (ZnPc) thin film. J Mater Sci: Mater Electron. 19: 482-486.

[83] Ohring, Milton. 2002. Material Science of Thin Film Deposition and Structure Second Edition. Academic Press. United State of America.

[84] Shen, X., Garces, L.J., Ding, Y., Laubernds, K., Zerger, R.P., Aindow, M., Neth, E.J, Suib,

[85] S.L., 2008, Behavior of H2 Chemisorption on Ru/TiO2 Surface and its Application in Evaluation of $R u$ Particle Sizes Compared with TEM and XRD Analyses, Elsevier ScienceDirect.

[86] K.Kulkarni. 2005. Substrate temperature effects on structural orientations and optical properties of Zinc Pthalocyanine ( $\mathrm{ZnPc}$ ) thin films. Materials Science and Engineering. 122: 100-105.

[87] Bushan, Bharat. 2003. Handbook of Nanotechnology. London Paris Tokyo: Springer-Verlag New York Berlin Heidelberg.

[88] Champaiboon, T., Efficiency enhancement of a tungsten oxide alcohol sensor.

[89] Davis, M.J., "Growth of Thin Films of Molybdenum and Tungsten Oxides by Combustion Chemical Vapour Deposition using Aqueous Precursor Solutions"

[90] Egerton, Ray F. 2005. Physical Principles of Electron Microscopy: An Introduction to TEM, $S E M$, and AEM. United States of America: Springer Science+Business Media, Inc.

[91] H. Imai, H. Moromoto, A. Tominaga, H. Hirashima, 1997. Structural changes in sol-derived $\mathrm{SiO} 2$ and $\mathrm{TiO} 2$ films by exposure to water vapour. J. Sol -Gel. Sci. Technol. 10, pp. 45-54.

[92] Knauth, Philippe; Schoonman, Joop. 2002. Nanocrystalline Metals and Oxides: selected Jurnal Properties and Applications. United States of America: Kluwer Academic Publishers.

[93] Lassner, Erik; Schubert Wolf-dieter. 1999. Tungsten: Properties, Chemistry, Technology of The Element, Alloys, and Chemical Compounds. United States of America: Kluwer Academic / Plenum Publishers.

[94] Pratapa, S. 2004. Prinsip-prinsip dan Implementasi Metode Rietveld untuk Analisis Data Difraksi. Surabaya.

[95] Suryadi. 2003. Fisika Plasma, Workshop Sputtering Untuk Rekayasa Permukaan Bahan. P3TM-BATAN, Yogyakarta

[96] Wasa, K. dan Hayakawa, S. 1992. Handbook of Sputter Depotition Technology, Principles. Technology and Aplictions, Noyes Publications, Osaka, Japan.

[97] Konuma, M. 1991. Film Deposition by Plasma Techniques. Internal Edition, Springer-Verlag Berlin Heldelberg, New York.

[98] Sujitno, B.A. Tjipto. 2003. Aplikasi Plasma dan Teknologi Sputtering Untuk SurfaceTreatmen. P3TM-BATAN, Yogyakarta. 
[99] Delhaes, P. 2002. Review Chemical vapor deposition and infiltration processes of carbon Materials Centre de Recherche Paul Pascal (CNRS and University of Bordeaux 1), Avenue Albert Schweitzer, F-33600 Pessac Cedex, France, Carbon 40 641-657

[100] Honoroto, E. L., Meadows, P. J. and Xiao, P. 2011. Fluidized bed chemical vapor deposition of pyrolytic carbon - I. Effect of deposition conditions on microstructure, Materials Science Centre, School of Materials, TheUniversity of Manchester, Grosvenor St.,Manchester ScienceDirect, http://www.elsevier.com/locate/pnucene

[101] R, Zainul. Desain dan Modifikasi Kolektor dan Reflektor Cahaya pada Panel Sel Surya $\mathrm{Au} / \mathrm{Cu}_{2} \mathrm{O}-\mathrm{Gel} \mathrm{Na}_{2} \mathrm{SO}_{4}$

[102] M., Yani, S. R., \& Zainul, R. (2017, September 4). Aktivasi Tanah Napa dan Pengaruhnya Terhadap Adsorpsi Ion Timbal (II)/ Pb2+. https://doi.org/10.31227/osf.io/ps523

[103] Zainul, R., Oktavia, B., Dewata, I., \& efendi, j. (2017, February 4). Studi Dinamika Molekular dan Kinetika Reaksi pada Pembelahan Molekul Air untuk Produksi Gas Hidrogen. https://doi.org/10.31227/osf.io/876s3

[104] Zainul, R., \& Dewata, I. (2015, December 29). Determination of $p H-B O D-C O D$ and degradation in batang arau watersheds at Padang city. https://doi.org/10.31227/osf.io/efdzj

[105] Zainul, R. (2016, September 24). Determination of the half-life and the quantum yield of ZnO semiconductor photocatalyst in humic acid. https://doi.org/10.31227/osf.io/e8a9x

[106] Zainul, R. (2016, December 18). Design and Modification of Copper Oxide Electrodes for Improving Conversion Coefficient Indoors Lights (PV-Cell) Photocells. https://doi.org/10.31227/osf.io/pgn84

[107] Zainul, R. (2016, November 19). Effect of Temperature and Particle Motion against the ability of $\mathrm{ZnO}$ Semiconductor Photocatalyst in Humic Acid. https://doi.org/10.31227/osf.io/wnygb

[108] Zainul, R., Alif, A., Aziz, H., Arief, S., \& s. (2015, October 22). Photoelectrosplitting Water Mechanism at Carbon Electrode Surface using Indoor lights. https://doi.org/10.31227/osf.io/vcxq8

[109] H., Sanjaya, H., \& Zainul, R. (2016, August 30). Synthesis and Electrical Properties of ZnOITO and Al-ITO thin Film by Spin Coating Technique Through Sol Gel Process. https://doi.org/10.31227/osf.io/unrt4

[110] Anhar, A., Sumarmin, R., \& Zainul, R. (2016, August 30). Measurement of Glycemic Index of West Sumatera Local Rice Genotypes for Healthy Food Selection. https://doi.org/10.31227/osf.io/tgy8h

[111] M., Sanjaya, H., \& Zainul, R. (2015, December 30). Characterization of napa soil and adsorption of $\mathrm{Pb}$ (II) from aqueous solutions using on column method. https://doi.org/10.31227/osf.io/t8fh9

[112] Chaidir, z., Fadjria, N., A., \& Zainul, R. (2016, December 5). ISOLATION AND MOLECULAR IDENTIFICATION OF FRESHWATER MICROALGAE IN MANINJAU LAKE WEST SUMATERA. 
[113] Chaidir, z., Zainul, R., Nurakhbari, D., \& Salim, M. (2016, September 24). Optimization of Spirulina Platensis Culture for Antioxidant Production. https://doi.org/10.17605/OSF.IO/FD6E4

[114] R Zainul, B Oktavia, I Dewata and J Efendi. Thermal and Surface Evaluation on The Process of Forming a $\mathrm{Cu}_{2} \mathrm{O} / \mathrm{CuO}$ Semiconductor Photocatalyst on a Thin Copper Plate. IOP Conference Series: Materials Science and Engineering, Volume 335, conference 1

[115] M Mawardi, D Deyundha, R Zainul and R Zalmi P. Characterization of PCC Cement by Addition of Napa Soil from Subdistrict Sarilamak 50 Kota District as Alternative Additional Material for Semen Padang. IOP Conference Series: Materials Science and Engineering, Volume 335, conference 1

[116] Zainul, Rahadian (2015) Disain dan Modifikasi Kolektor dan Reflektor Cahaya pada Panel Sel Surya Al/Cu2O-Gel Na2SO4. Project Report. FMIPA UNP, Padang.

[117] Zainul R, Alif A, Aziz H, Arief S, Syukri, Munaf E. 2015. Research Journal of Pharmaceutical Biological Chemical Science 6.4. July-August:353-61

[118] R Zainul, A Alif, H Aziz, S Arief - Jurnal Riset Kimia, 2015. DISAIN GEOMETRI REAKTOR FOTOSEL CAHAYA RUANG. https://doi.org/10.25077/jrk.v8i2.230

[119] M Anwar, E Munaf, S Kosela, W Wibowo, R Zainul - Journal of Chemical and Pharmaceutical Research, 2015. Journal of Chemical and Pharmaceutical Research, 2015, 7 (11): 715-722

[120] M Anwar, E Munaf, S Kosela, W Wibowo, R Zainul - Journal of Chemical and Pharmaceutical Research, 2015. Journal of Chemical and Pharmaceutical Research, 2015, 7 (11): 715-722*

[121] R Zainul, A Alif, H Aziz, S Arief, S Dradjad, E Munaf - RESEARCH JOURNAL OF PHARMACEUTICAL ..., 2015. Design of photovoltaic cell with copper oxide electrode by using indoor lights 